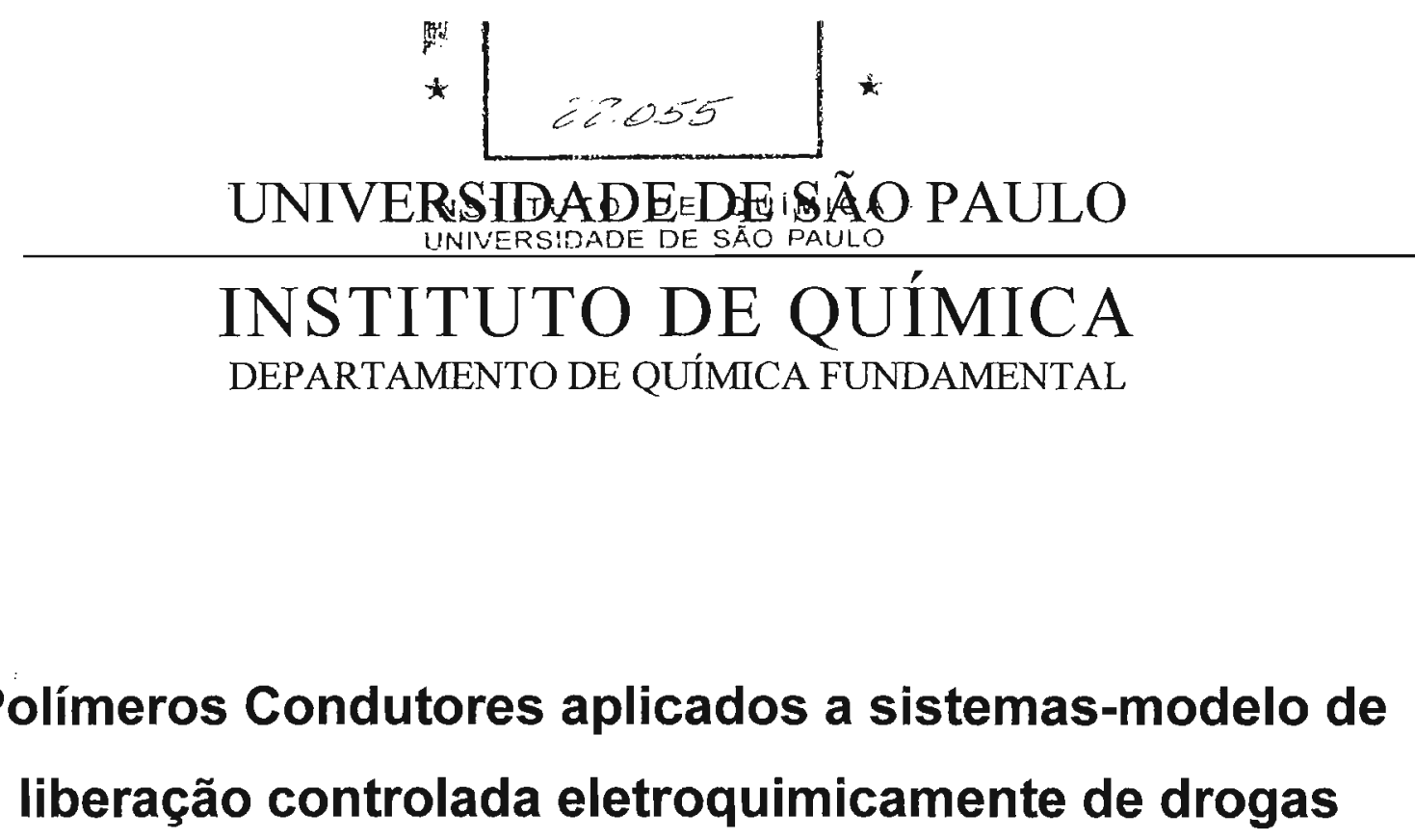

Luiz Marcos de Lira Faria

Tese apresentada ao Instituto de Química, da Universidade de São Paulo,como parte das exigências para a obtenção do título de Doutor em Química.

Orientadora: Prof ${ }^{a}$. Dr ${ }^{a}$. Susana Inês Córdoba de Torresi 


\title{
Polímeros Condutores aplicados a sistemas-modelo de liberação controlada eletroquimicamente de drogas
}

\author{
Luiz Marcos de Lira Faria
}

\begin{abstract}
Tese apresentada ao Instituto de Química, da Universidade de São Paulo,como parte das exigências para a obtenção do título de Doutor em Química.
\end{abstract}

Orientadora: Prof ${ }^{\mathrm{a}}$. Dr ${ }^{\mathrm{a}}$. Susana Inês Córdoba de Torresi 


\section{“Polímeros condutores aplicados a sistemas-modelo de liberação controlada eletroquimicamente de drogas"}

\section{LUIZ MARCOS DE LIRA FARIA}

Tese de Doutorado submetida ao Instituto de Química da Universidade de São Paulo como parte dos requisitos necessários à obtenção do grau de Doutor em Química - Área: Físico-Química.

Aprovado(a) por:

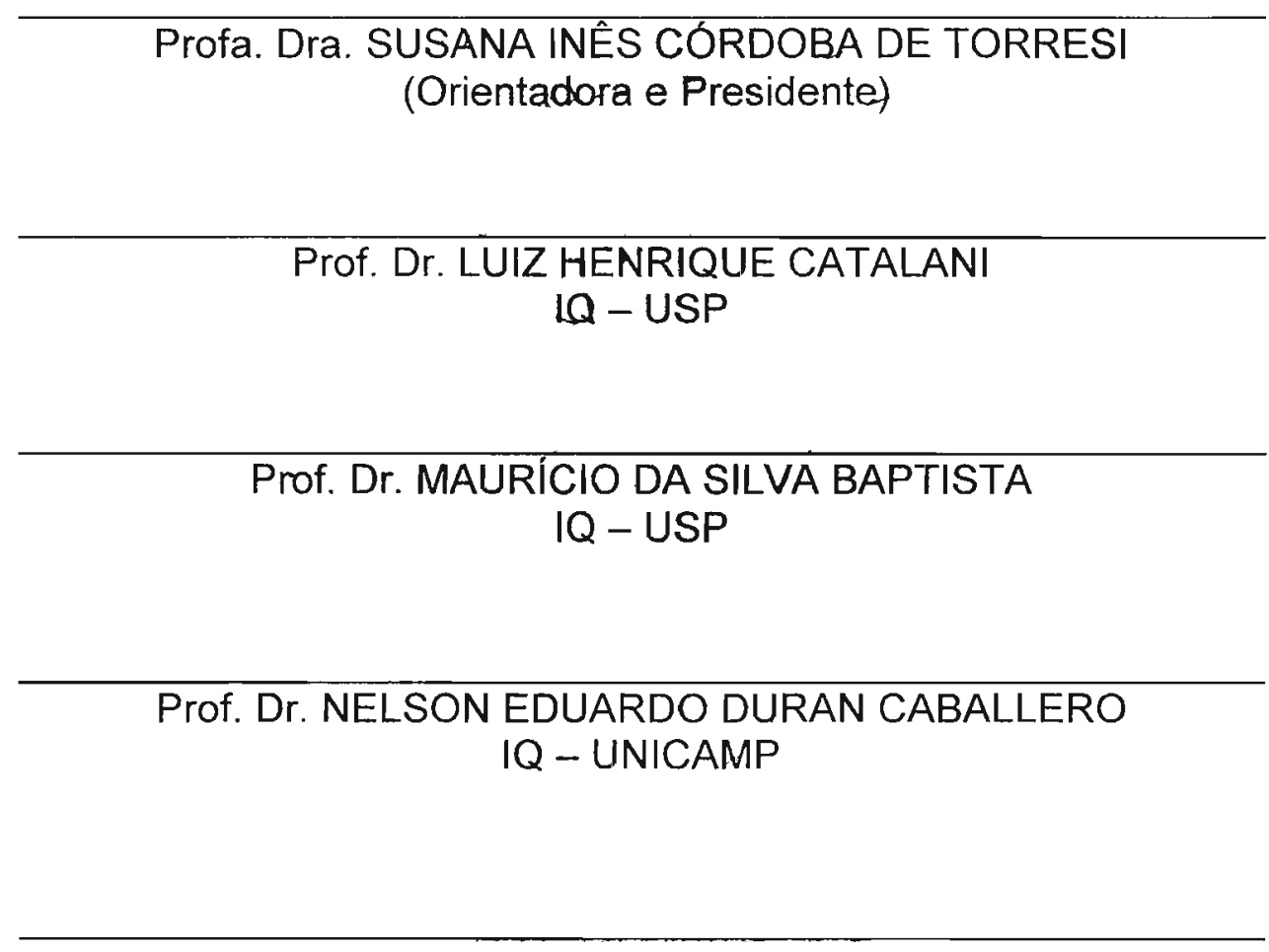

Profa. Dra. CARLA MARIA NASCIMENTO POLO DA FONSECA USF 


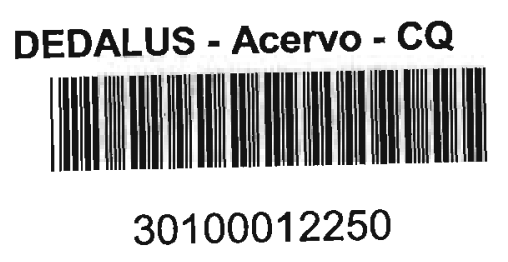

Ficha Catalográfica

Elaborada pela Divisão de Biblioteca e Documentação do Conjunto das Químicas da USP.

\section{Faria, Luiz Marcos de Lira}

F224p Polímeros Condutores aplicados a sistemas-modelo de liberação controlada eletroquimicamente de drogas / Luiz Marcos de Lira Faria. -- São Paulo, 2006. $152 \mathrm{p}$.

Tese (doutorado) - Instituto de Química da Universidade de São Paulo. Departamento de Química Fundamental.

Orientador: Torresi, Susana Inês Córdoba de

1. Eletroquímica 2. Polímeros: Condutor I. T. II. Torresi, Susana Inês Córdoba de, orientador. 
Aos meus pais Izilda Maria de Lira Faria e Luiz Marcos de Faria, À minha melhor amiga e companheira Isabel Irino Ramos Pelo amor, compreensão e toda ajuda, Dedico este trabalho 


\section{Agradecimentos}

À minha orientadora, Prof. ${ }^{\mathrm{a}} \mathrm{Dr}^{\mathrm{a}}{ }^{\mathrm{a}}$ Susana Inês Córdoba de Torresi, presente em minha formação desde a iniciação científica, por toda paciência, amizade, conhecimentos transmitidos e principalmente pela confiança durante vários anos de minha vida;

Ao Prof. Dr. Roberto Torresi, pela convivência e ensinamentos transmitidos;

A todos os colegas do Laboratório de Materiais Eletroativos, pela amizade e incentivo;

À Prof. Marina Tavares, pela colaboração no projeto;

Ao Prof. Luiz Catalani, pela inestimável ajuda nos experimentos de GPC e densidade de polímeros;

À Prof. ${ }^{\mathrm{a}} \mathrm{Dr}^{\mathrm{a}}$ Márcia Arruda Temperine e ao Gustavo pela obtenção de espectros Raman;

Aos funcionários do IQ, principalmente, Paulinho e Nivaldo;

Ao Instituto de Química/USP e à FAPESP, pelas melhores condições para desenvolver este trabalho. 
Índice

1.1.1 - Classificação dos sistemas de liberação com velocidade controlada

1.1.1.1 - Sistemas de liberação de droga por velocidade programada

1.1.1.2 - Sistemas de liberação de droga por ativação modulada

1.1.1.3 - Sistemas de liberação de droga regulado por reação

1.1.2 - Sistemas de liberação controlada de drogas in vivo

1.2.1 - Polianilinas

1.2.2 - Polímeros condutores aplicados a sistemas de liberação controlada

1.2.3 - Biocompatibilidade de polímeros condutores 
3.3.6 - Medidas de massa e densidade dos hidrogéis sintetizados $\quad 29$

3.3.7 - Matrizes para a síntese dos compósitos hidrogel / polímero condutor 29

3.3.8 - Preparação dos eletrodos encapsulados com hidrogel de PAAm e síntese do compósito hidrogel/polímero condutor $\quad 30$

3.3.9 - Caracterização do compósito hidrogel/polímero condutor 30

3.3.9.1 - Microscopia Raman e de Força Atômica $\quad 30$

3.3.9.2 - Microscopia eletrônica de varredura $\quad 31$

3.3.9.3 - Microscopia óptica "in situ” 31

3.3.10 - Liberação de pirocatecol violeta, safranina e tetraciclina a partir do compósito hidrogel/polímero condutor 32

3.3.11 - Microbalança Eletroquímica a cristal de Quartzo (MECQ) 32

4.1 - Classificação dos sistemas de liberação controlada de drogas baseados em polímeros condutores 34 4.2 - Primeiros sistemas estudados: Geração I 34

4.2.1 - Sistema PANI/AS $\quad 35$

4.2.2 - Sistema PANI/Náfion/DOPA $\quad 44$

$\begin{array}{ll}4.2 .3 \text { - Mais estudos (e conclusões) sobre sistemas da Geração I } & 61\end{array}$

4.3 - Sistemas de liberação controlada eletroquimicamente de drogas baseado em polímeros condutores: Geração II

4.3.1 - Redes condutoras semi-interpenetrantes de polianilina / poliacrilamida 64

4.3.2 - Caracterização espectroscópica / microscópica de redes condutoras semi-interpenetrantes de polianilina / poliacrilamida: Espectroscopia / Microscopia Raman 67

4.3.3 - Caracterização microscópica de redes condutoras semi-interpenetrantes de polianilina / poliacrilamida:

$\begin{array}{ll}\text { Microscopia de Força Atômica. } & 72\end{array}$

4.3.4 - Distribuição do polímero condutor no interior da matriz de hidrogel $\quad 77$

4.3.5 - Síntese e estudo de hidrogéis de poliacrilamida com diferentes tamanhos de poro 78

4.3.6 - Caracterização microscópica de redes condutoras semi-interpenetrantes de polianilina / poliacrilamida: $\begin{array}{lr}\text { Microscopia Eletrônica de Varredura } & 80\end{array}$

$\begin{array}{lr}\text { 4.3.6.1 - Imagens dos hidrogéis } & 80\end{array}$

$\begin{array}{lr}\text { 4.3.6.2 - Imagens dos compósitos } & 84\end{array}$

4.3.7 - Redes condutoras semi-interpenetrantes de polianilina/poliacrilamida como sistemas de liberação controlada eletroquimicamente de moléculas-modelo $\quad 88$

4.3.7.1 - Estudo da liberação controlada eletroquimicamente de safranina a partir de compósitos de $\begin{array}{lr}\text { polianilina/poliacrilamida } & 90\end{array}$

4.3.7.1.1 - Efeito do pH da solução de liberação $\quad 94$

4.3.7.1.2 - Efeito da quantidade de polianilina no compósito: carga de eletropolimerização 97

4.3.7.1.3 - Efeito dos diferentes tamanhos de poros das matrizes de poliacrilamida $\quad 100$

4.3.7.2 - Comparação e análise dos resultados da parametrização da liberação de safanina 102

4.3.7.3 - Atuação de redes condutoras semi-interpenetrantes de poliacrilamida / polianilina 105

4.3.7.3.1 - Propriedade de músculo artificial das redes condutoras semi-interpenetrantes

$\begin{array}{ll}\text { de poliacrilamida / polianilina } & 106\end{array}$

4.3.7.3.2 - Liberação de pirocatecol a partir de redes condutoras semi-interpenetrantes

$\begin{array}{lr}\text { de poliacrilamida / polianilina } & 107\end{array}$ 
4.3.7.3.3 - Mecanismo de atuação das redes condutoras semi-interpenetrantes em sistemas

de liberação controlada

4.3.7.2 - Liberação controlada de tetraciclina 
Resumo

Este trabalho descreve a síntese, caracterização e aplicação de sistemas poliméricos baseados em polímeros condutores em sistemas de liberação controlada de drogas. Esta tese pode ser dividida em duas partes: na primeira se apresentam os resultados da aplicação de filmes de polianilina e polipirrol na liberação de drogasmodelo como a dopamina protonada e o ácido salicílico. Na liberação de salicilato utilizou-se um filme polianilina eletrosintetizado e dopado com íons cloreto. Já para a liberação de dopamina protonada (um cátion) a liberação foi conduzida a partir de um sistema bicamadas, com um filme de polianilina recoberta com uma camada de Náfion. É mostrada a liberação controlada nos dois casos, porém também se discutem limitaçãoes deste tipo de sistema que levaram ao estudo de uma forma alternativa de controle eletroquímico utilizando polímeros condutores.

A segunda parte do trabalho mostra então esta nova metodologia que se baseia em compósitos de poianilina eletropolimerizada no interior de hidrogéis de poliacrilamida. É mostrado que este novo material é eletroativo e mantém as características de intumescimento dos hidrogéis, tanto necessárias ao desenvolvimento destes sistemas de liberação controlada. Mecanismos para o crescimento e distribuição da polianilina na matriz isolante e para a atuação do compósito no controle eletroquímico da liberação são propostos com base nos dados de microscopia de força atômica, Raman e eletrônica de varredura, além de testes de liberação controlada com moléculas de diferentes cargas. 
Abstract

This work describes the synthesis, characterization and application of polimeric systems based on contucting polymers for electrochemical release devices. The thesis is divided into two parts: first, results concerning the application of polyaniline and polypyrrole films in the controlled release of dopamine and salicilyc acid, are showed. An electrosyntetized polyaniline film doped with chloride ions was used in the salicilate release. On the other hand, for the controlled release of protonated dopamine, a bilayer system consisting of a polyaniline film recovered with Nafion was employed. The release control was reached in both cases, but this kind of actuator show serious limitations that lead to the conclusion that a new type of electrochemical control based in conducting polymers must be developped.

The second part shows the new methodology based on composites of polyaniline grown inside polyacrylamide hydrogels. It's showed that this new material is electroactive and still maintains the hydrogel's swelling properties, which makes it an interesting and suitable material for drug delivery devices. Raman Microscopy, Scaning Electron Microscopy and Atomic Force Microscopy, and controlled release tests of different charged molecules were tools for the elucidation of polyaniline's growth and distribuition inside the hydrogels and for the mecanism of actuation in the controlled release. 


\section{Abreviações e Símbolos}

\begin{tabular}{|c|c|}
\hline$\% \mathrm{C}$ & $\%$ em massa de $\mathrm{MBA}$ na soma $\mathrm{MBA}+\mathrm{AAM}$ \\
\hline$\% \mathrm{~T}$ & $\%$ em massa de $\mathrm{AAM}+\mathrm{MBA}$ na soma $\mathrm{AAM}+\mathrm{MBA}+100 \mathrm{~mL}$ de $\mathrm{H}_{2} \mathrm{O}$ \\
\hline$\sigma$ & condutividade \\
\hline$\phi$ & Eficiência do controle eletroquímico \\
\hline$\xi$ & Tamanho de poro \\
\hline$\triangle \mathrm{E}$ & Variação de potencial \\
\hline$\triangle \mathrm{f}$ & Variação de frequiência \\
\hline$\triangle \mathrm{t}$ & Variação de tempo \\
\hline$\triangle \mathrm{V}$ & Variação de velocidade de liberação \\
\hline $5-\mathrm{FU}$ & 5-Fluoaracil \\
\hline A & Área \\
\hline AAM & Acrilamida \\
\hline AFM & Microscopia de força atômica \\
\hline AS & Ácido salicílico \\
\hline ATP & Adenosina trifosfato \\
\hline $\mathrm{C}_{\mathrm{n}}$ & Coeficiente de rigidez \\
\hline $\mathrm{DBS}^{-}$ & docecilbenzenosulfonato \\
\hline DBSA & Ácido dodecilbenzenosulfônico \\
\hline DOPA & Dopamina \\
\hline$d_{r}$ & Densidade do hidrogel relaxado \\
\hline$d_{s}$ & Densidade do hidrogel intumescido \\
\hline $\mathrm{E}$ & Potencial \\
\hline $\mathrm{ECA}$ & Potencial de circuito aberto \\
\hline ECS & Eletrodo de calomelano saturado \\
\hline ECZ & Eletroforese capilar por zona \\
\hline $\mathrm{E}_{\mathrm{p}}$ & Potencial de pico \\
\hline EVA & Etileno-co-acetato de vinila \\
\hline $\mathrm{Glu}^{-}$ & glutamato \\
\hline GPC & Cromatografia por permeação em gel \\
\hline HPLC & Cromatografia liquida de alta performance \\
\hline I & Força iônica \\
\hline
\end{tabular}




\begin{tabular}{ll}
\hline LFM & Microscopia de força lateral \\
MBA & N,N'-metileno-bis-acrilamida \\
$M_{\mathrm{c}}$ & Massa molar numérica média entre ligações cruzadas \\
MECQ & Microbalança eletroquímica à cristal de Quartzo \\
MEV & Microscópio/microscopia eletrônico(a) de varredura \\
$M_{n}$ & Massa molar numérica média \\
$m_{\mathrm{r}}$ & Massa do hidrogel relaxado \\
$\mathrm{m}_{\mathrm{s}}$ & Massa do hidrogel intumescido \\
PAAM & Poliacrilamida \\
PANI & Polianilina \\
PC & Polímero condutor \\
PEO & Poli(óxido de etileno) \\
PHEMA & Poli(2-hidroetil-metacrilato) \\
PPy & Polipirrol \\
PSS & Poli(estireno sulfonato) \\
Pt & Platina \\
Q & Razão entre volumes de equilibrio \\
RR & Raman ressonante \\
SLD & Sistema de liberação de drogas \\
SPAN & Polianilina sulfonada \\
TEMED & N,N,N'N'-tetrametiletilenodiamina \\
UV-Vis & Radiação ultra-violeta / visível \\
$\mathrm{v}$ & Velocidade de varredura \\
VC & Voltametria cíclica \\
$V_{\text {oxi }}$ & Velocidade de liberação no estado oxidado \\
$V_{\text {red }}$ & Velocidade de liberação no estado reduzido \\
$\mathrm{X}$ & Razão de reticulação \\
$\delta$ & espessura \\
$\lambda$ & Comprimento de onda \\
$\rho_{2}$ & Densidade do polímero não-reticulado \\
$\rho_{\mathrm{x}}$ & Densidade de ligações cruzadas \\
$\chi$ & Parâmetro de Flory \\
\hline &
\end{tabular}




\section{1 - Introdução geral}

Antes da abordagem técnica-científica que concerne o estudo de sistemas de liberação controlada de drogas, vê-se necessário traçar um panorama social atual que justifique esforços na busca de avanços em tal área. Assim, para se abordar a necessidade de formas alternativas de se administrar medicamentos, a AIDS é talvez o melhor exemplo, pois uni questões como a dificuldade de aderência ao tratamento devido à sua complexidade (terapia combinada) e a quebra de patentes dos vários antivirais com a possibilidade da produção de genéricos no país.

As dimensões globais da epidemia (a UNAIDS estima em 33 milhões de pessoas vivendo com HIV no mundo, e o Ministério da Saúde em 536 mil o número de infectados no Brasil - dados de 2001) e a mobilização da sociedade civil por meio de organizações não governamentais justificam e garantem a prioridade de uma política pública para este setor.

Assim o Governo Federal, por meio da Coordenação Nacional de DST/AIDS do Ministério da Saúde, e as Secretarias Estaduais e Municipais de Saúde têm se empenhado na elaboração e implementação de políticas públicas éticas, efetivas e democráticas no que se refere ao HIV/AIDS. A distribuição universal de medicamentos, iniciada em 1991 no Estado de São Paulo com o AZT e hoje garantida por lei em todo o país, marca um importante diferencial (e referencial) da política brasileira de assistência em relação à maioria dos países afetados. O Brasil foi o primeiro país do "terceiro mundo" a adotar a política de distribuição gratuita e universal de medicação antiretroviral.

Aqui é necessário abrir um parêntese e citar que além do fator econômico, um segundo grande desafio se apresenta quando lida-se com a eficácia de um tratamento como este: a capacidade de se garantir a adesão dos pacientes aos esquemas terapêuticos preconizados.

Uma política nacional que garanta o acesso à medicação tem que ser acompanhada por esquemas que garantam que a terapia seja seguida corretamente, aí diversos fatores sociais aliados à freqüência e a quantidade de comprimidos a ser ingerida diariamente (até 40 por dia) levam a uma não fidelidade total ao tratamento de $73 \%$ no Estado de São Paulo de acordo com a publicação "Tá Dificil de Engolir" 1 . Este texto traz pesquisas e depoimentos que mostram as dificuldades e as esperanças no que diz respeito a aderência ao tratamento anti-retroviral, e aqui, para destacar a importância 
de dispositivos de liberação controlada que facilitem a administração de drogas, cabe a reprodução de um trecho que faz parte da conclusão dos pesquisadores que escreveram o livro: “...são necessários urgentemente esquemas mais simples, de preferência uma vez por dia. Do contrário, a longo prazo, os pacientes não vão agüentar." - referência 1, pág. 142. Esta citação traduz a necessidade de formas alternativas de se tomar os coquetéis frente à ameaça de fracasso do tratamento.

Atualmente, menos de um quinto dos HIV-positivos é beneficiado pelo coquetel de medicamentos oferecido gratuitamente pelo governo e a expectativa é que esse número aumente após o efeito de redução de custo que a entrada de novos genéricos vai causar. Assim aumentam também os problemas relacionados à aderência ao tratamento, o que torna essencial a busca de novos dispositivos, sistemas de liberação controlada de drogas, que facilitem esse tratamento.

\section{1 - Sistemas de liberação controlada de drogas}

Por várias décadas o tratamento de uma doença aguda ou crônica foi realizado com o uso de drogas ministradas através de comprimidos, capsulas, pílulas, supositórios, cremes, pomadas, líquidos, aerossóis e drogas injetáveis. Até mesmo hoje em dia estes sistemas convencionais de transporte de drogas são os produtos farmacêuticos primários comumente prescritos e dominam o mercado. Estes tipos de carregadores de drogas são conhecidos por promoverem uma pronta liberação da droga. Todavia para alcançar e manter a concentração de droga num nível de eficiência terapêutica necessária para o tratamento é freqüentemente necessário recorrer a esse tipo de liberação de drogas várias vezes num dia. $\mathrm{E}$, como pode ser visto na Figura 1, isto resulta numa significante flutuação dos níveis de droga no organismo.

Recentemente vários avanços técnicos foram realizados, resultando no desenvolvimento de novas técnicas para a liberação de drogas. Estas técnicas são capazes de controlar a velocidade de liberação de drogas, mantendo a duração da atividade terapêutica, e/ou liberando a droga numa exata localização ${ }^{2}$. Estes avanços levaram ao desenvolvimento de vários novos sistemas de liberação de drogas que revolucionaram a metodologia das medicações e promoveram um grande número de benefícios terapêuticos. Dessa nova tecnologia surgiram algumas novas terminologias, e o termo "liberação controlada" implica na predição e na reprodutibilidade da cinética de liberação da droga. 


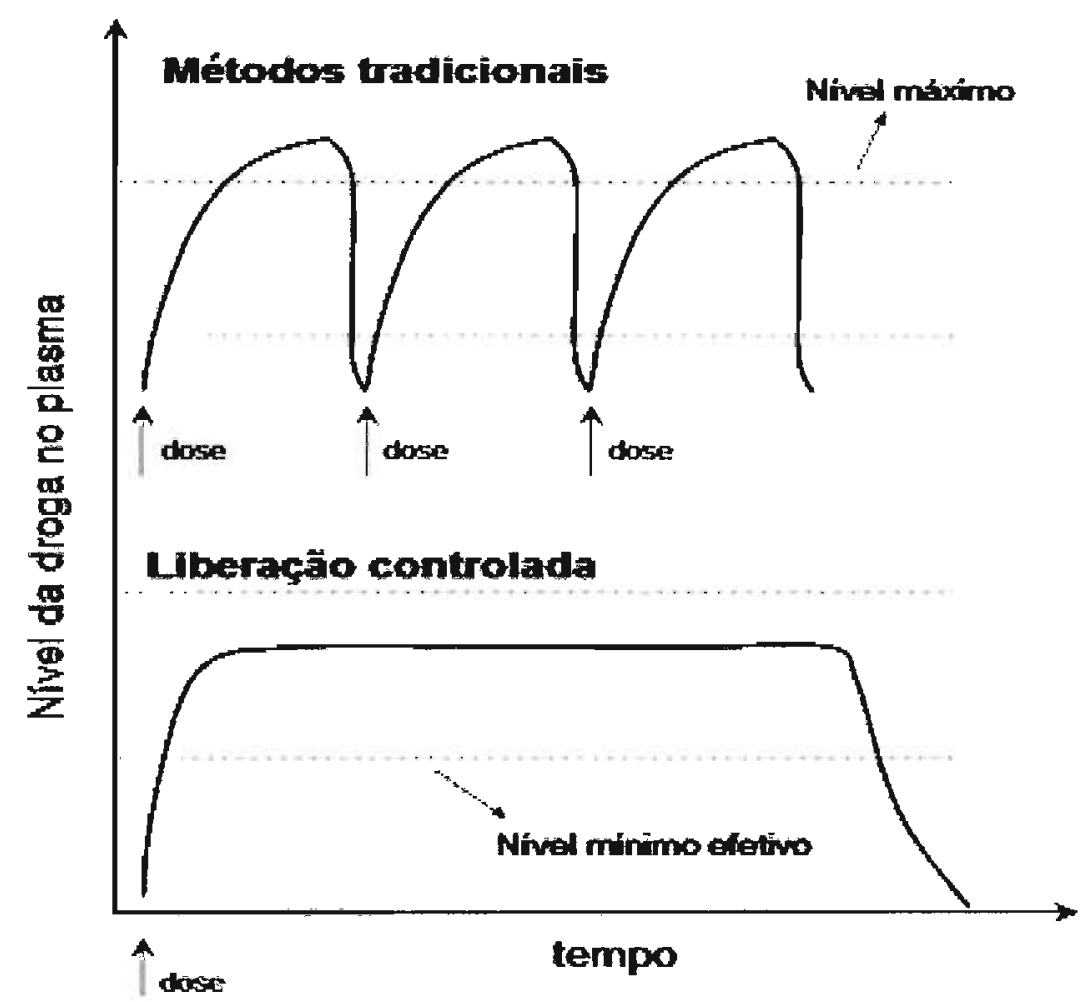

Figura 1 - Perfis hipotéticos da concentração de droga no organismo resultante da administração consecutiva de doses múltiplas por um sistema convencional, que libera a droga toda imediatamente, comparado com um sistema de liberação ideal (adaptado da ref. 2).

1.1.1 - Classificação dos sistemas de liberação com velocidade controlada

Baseado no grau de sofisticação técnica, os sistemas de liberação controlada que estão sendo recentemente comercializados ou ainda estão em desenvolvimento, podem ser classificados como:

1. Sistemas de liberação de droga (SLD) por velocidade programada;

2. SLD por ativação modulada;

3. SLD regulado por reação;

4. SLD em local alvo.

1.1.1.1 - Sistemas de liberação de droga por velocidade programada

Neste grupo de SLD, a liberação de moléculas de drogas do sistema é programada segundo um perfil específico de velocidade. Isto é alcançado pelo desenho 
do sistema, o qual controla a difusão molecular do medicamento numa membrana (e através dela) que separa o sistema de liberação da sua vizinhança. Nestes casos a Lei da Difusão de Fick é freqüentemente seguida.

Dentro deste grupo encontramos as seguintes sub-classificações: (i) SLD controlada por permeação em membrana polimérica; (ii) SLD controlado por difusão em matriz polimérica; (iii) SLD controlada por partição de microreservatórios. Os três sistemas são amplamente comercializados ${ }^{3}$ e se constituem de implantes ou sistemas de absorção transdérmicos, todos com leis cinéticas bem estabelecidas em termos de parâmetros físico-químicos como coeficientes de partição e difusão, solubilidade da droga, e parâmetros particulares da construção do sistema, como a espessura da membrana polimérica entre outros.

\subsubsection{2 - Sistemas de liberação de droga por ativação modulada}

Neste grupo de sistemas a liberação é ativada por algum processo físico, químico ou biológico e/ou facilitada por um suprimento externo de energia. A velocidade da liberação da droga é então controlada regulando o processo ou a quantidade de energia aplicada. Baseado na natureza do processo aplicado ou no tipo de energia usada, estes sistemas de liberação de droga por ativação modulada podem ser classificados nas seguintes categorias ${ }^{3}$ :

1. Processos físicos:
a) SLD ativado por pressão osmótica
b) SLD ativado por pressão hidrodinâmica
c) SLD ativado por pressão de vapor
d) SLD ativado mecanicamente
e) SLD ativado magneticamente
f) SLD ativado por sonoforese
g) SLD ativado por iontoforese
h) SLD ativado por hidratação

2. Processos químicos:

a) SLD ativado por $\mathrm{pH}$ 
b) SLD ativado por íon

c) SLD ativado por hidrólise

3. Processos bioquímicos:

a) SLD ativado por enzima

b) SLD ativado bioquimicamente.

Este grupo de sistemas é bem amplo, assim o quadro da tabela 1 resume as propriedades de alguns exemplos. É importante notar que muitos sistemas de liberação controlada se utilizam de polímeros sintéticos, que para o seu uso 'in vivo' tem que ser quimicamente inertes e livres de impurezas.

Tabela 1 - Alguns mecanismos que acionam a liberação da droga no organismo.

Estímulo

pH

Força Iônica

Espécies químicas

Enzima-substrato

Magnético

Ultrasom

Elétrico

\section{Polímero}

hidrogel ácido ou básico

hidrogel iônico

Hidrogel contendo grupos aceptores de elétrons

Hidrogel contendo enzimas imobilizadas

Partículas magnéticas dispersas nas microesferas poli(etileno-vinil álcool)

\section{Mecanismo}

Mudança do $\mathrm{pH}$ - entumecimento liberação da droga

Mudança na força iônica - alteração na carga efetiva do hidrogel — mudança na conformação - liberação da droga

Formação de complexo de transferência de carga - mudança na conformação liberação da droga

Substrato presente - conversão enzimática - produto muda a conformação do hidrogel - liberação da droga

Campo magnético aplicado - mudança nos poros da microesfera - liberação da droga

Irradiação de ultrasom - aumento da temperatura -liberação da droga

Campo elétrico aplicado - carregamento da membrana - difusão da droga carregada mudança na carga do polímero - liberação da droga

\subsubsection{3 - Sistemas de liberação de droga regulado por reação}

Neste grupo de SLD a liberação da molécula de droga é ativada por um agente disparador, como uma substância bioquímica, e é regulada pela sua concentração via alguns mecanismos reacionais. A velocidade da liberação é então controlada pela 
concentração do agente disparador detectada por um sensor no mecanismo de regulação por reação. Como exemplo mais significativo desta classe, tem-se os SLD autoregulados, e como principal exemplo pode ser citado aquele em que a quantidade de insulina liberada é auto-regulada pela concentração de glicose que penetra no sistema de liberação.

\subsection{2 - Sistemas de liberação controlada de drogas "in vivo"}

Sistemas de liberação controlada já foram descritos para as mais diversas formas de administração: nasal, oral, mucosal, ocular, transdermal, parenteral (implantes e formas injetáveis), vaginal e intrauterina ${ }^{4}$.

Em sua grande maioria, tais sistemas liberam a droga com velocidade controlada devido à atuação de um polímero. A droga, desta forma, é liberada por diversos mecanismos, como difusão, biodegradação do polímero, hidratação (intumescimento de hidrogéis), ou a combinação deles. $\mathrm{O}$ desenho do dispositivo depende intimamente do tipo de administração ao qual ele servirá. A geometria das membranas poliméricas não está menos vinculada à forma de administração, sendo mais comuns as esferas, cilindros e lâminas ${ }^{4}$. A formulação nestes dispositivos também é variada e a droga pode estar dissolvida ou dispersa em um líquido ou numa matriz polimérica. A droga pode estar na sua forma pura, sólida ou líquida.

Para sistemas poliméricos, existem três configurações básicas: dispositivos tipo reservatório, tipo matriz e híbridos matriz reservatório como é mostrado na Figura 2. Cada configuração possui uma descrição matemática da difusão do fármaco através do polímero (matriz ou membrana) e a predição e o controle da velocidade de liberação é alcançada trabalhando-se com parâmetros como espessura da camada polimérica, porosidade, coeficiente de difusão da droga, concentração inicial da droga no dispositivo, entre outros. Portanto, tais sistemas são controlados por difusão, então a força termodinâmica que dirige a liberação é o gradiente de concentração e predições de suas propriedades podem ser feita com base nas leis de Fick da difusão.

Sistemas de liberação controlados por permeação em membranas poliméricas (sistemas tipo reservatório) são sistemas com velocidade programada (ou préprogramada), onde a droga é totalmente ou parcialmente encapsulada em um reservatório. A superfície de liberação é recoberta por uma membrana polimérica, com uma específica permeabilidade, que é o elemento controlador da velocidade. $O$ 
reservatório da droga pode existir na forma sólida, em solução ou em suspensão. A membrana polimérica pode ser fabricada a partir de um material polimérico não-poroso (homogêneo ou heterogêneo) ou microporoso (semipermeável). A encapsulação da formulação (droga) no reservatório pode ser realizada por injeção em molde, "spray coating", capsulação, microencapsulação, ou outras técnicas. Diferentes formas e tamanhos de sistemas podem ser fabricados como pode ser visto na Figura 3.

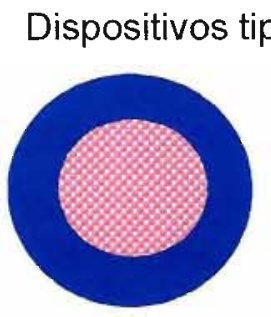

Droga dispersa

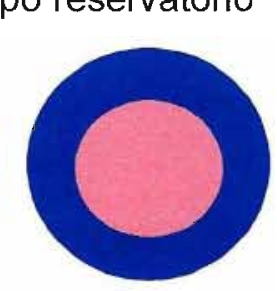

Droga dissolvida

\section{Dispositivos tipo matriz}

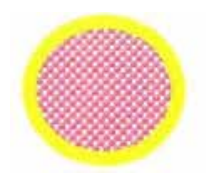

Droga dispersa Droga dissolvida

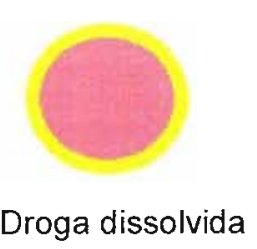

Dispositivos híbridos

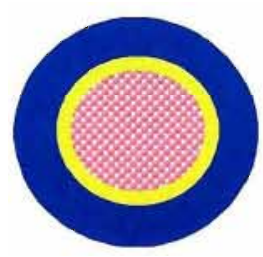

Droga dispersa

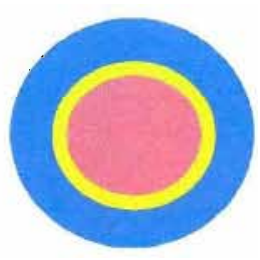

Droga dissolvida

Figura 2 - Configurações para SLDs poliméricos. Região azul: membrana polimérica que delimita o reservatório da droga. Linha amarela: limite da matriz polimérica contendo a droga.

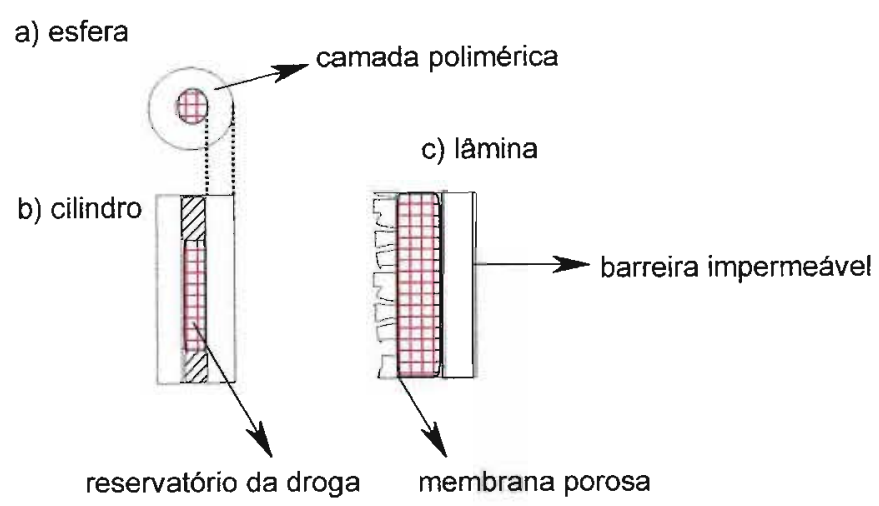

Figura 3 - Tipos de sistemas de liberação controlados por permeação em membranas poliméricas (sistemas tipo reservatório): a) esfera, b) cilindro e c) lâmina. As membransa poliméricas podem ser porosas ou não-porosas. 
Exemplos de dispositivos deste tipo comercializados são dados a seguir:

1) Progestasert IUD, um dispositivo intrauterino, onde o reservatório da droga é uma suspensão de cristais de progesterona em fluido médico de silicone encapsulada no braço vertical de um dispositivo na forma de $T$ revestido por uma membrana não porosa de copolímero de acetato de vinila e etileno. O dispositivo foi desenvolvido para liberar progesterona continuamente na cavidade uterina numa velocidade de $65 \mu \mathrm{g} / \mathrm{dia}$ para a contracepção durante um ano ${ }^{3}$.

2) Norplant subdermal implant é fabricado a partir tubo de silicone não poroso de grau médico (com ambos os lados selados com adesivo de silicone) para o encapsulamento de cristais de levonogestrel (geração I) ou dispersão de levonorgestrel em matriz sólida de elastômero de silicone (geração II). Foi desenvolvido para a liberação subcutânea contínua de levonorgestrel numa dose diária de $30 \mu \mathrm{g}$, por um período de até 7 anos $^{3}$.

3) No sistema Ocusert (um inserto ocular) o reservatório da droga é um fino disco de complexo de alginato com o fármaco pilocarpina posto entre duas lâminas transparentes de copolímero de etileno e acetato de vinila. Essas membranas microporosas permitem que a entrada do fluido lacrimal no reservatório dissolva a pilocarpina e a libere do complexo. Pelo desenho do sistema, moléculas da droga são liberadas a uma constante velocidade de 20 ou $40 \mu \mathrm{g} / \mathrm{h}$ para o tratamento de glaucoma por mais de 7 dias $^{3}$.

4) Transderm Nitro é um sistema terapêutico transdérmico no qual o reservatório da droga, uma dispersão de nitroglicerina-lactose em fluido de silicone médico, é encapsulado em uma peça elipsoidal formada por uma lâmina plástica metalizada impermeável à droga e por uma superfície controladora da velocidade de liberação formada por uma membrana de um copolímero de etileno e acetato de vinila. Uma fina camada de adesivo de silicone sensível à pressão recobre o copolímero para garantir um íntimo contato da superfície liberadora com a pele. $O$ sistema libera $0,5 \mathrm{mg} \cdot \mathrm{cm}^{-2} \cdot \mathrm{dia}^{-1} \mathrm{de}$ nitroglicerina para o tratamento de angina ${ }^{3}$.

Em sistemas de liberação controlados por difusão em matrizes poliméricas (dispositivos tipo matriz), o reservatório da droga é preparado pela dispersão das partículas da espécie ativa numa matriz polimérica controladora da velocidade de liberação, que pode ser fabricada a partir de um polímero hidrofóbico ou hidrofílico. A dispersão da droga na matriz polimérica é realizada 1- pela mistura de partículas 
finamente divididas com o polímero líquido ou com uma solução altamente viscosa do polímero, seguido por entrecruzamento de suas cadeias, ou 2- misturando a droga sólida com um polímero numa elevada temperatura. A dispersão resultante é então moldada ou extruída para formar dispositivos de formas e tamanhos variados. Outra técnica de fabricação, é a dissolução da droga e do polímero num solvente comum, seguido da evaporação deste solvente à altas temperaturas e/ou com vácuo. Exemplos comerciais deste tipo de sistema são:

1))Nitro-Dur, um dispositivo transdérmico, fabricado pelo aquecimento de uma solução aquosa de glicerol e poli(álcool viinílico). A temperatura da solução é gradativamente diminuída e nitroglicerina e lactose são dispersas numa temperatura um pouco acima do ponto de congelamento da mistura. A dispersão é solidificada num molde, abaixo ou na temperatura ambiente, e então cortada para formar um disco polimérico com o medicamento. Depois de um dos lados ser selado com uma lâmina de plástico metalizado, um sistema tipo "patch" é produzido com uma borda adesiva ao redor da lâmina. O dispositivo foi desenvolvido para aplicação sobre a pele durante $24 \mathrm{~h}$ propiciando uma contínua infusão transdérmica de nitroglicerina numa dosagem de 0,5 mgcm ${ }^{-2} \mathrm{dia}^{-13}$.

2) Compoduse Subdermal Implant, é um implante subcutâneo fabricado pela dispersão de microcristais de estradiol num elastômero de silicone. Um bastão de silicone (sem a droga) é então preenchido com a dispersão, formando um implante cilíndrico. A liberação controlada de estradiol por 200 ou 400 dias promove o melhor crescimento de novilhos ${ }^{3}$.

Inúmeros exemplos de sistemas poliméricos usados na liberação controlada de fármacos poderiam ser citados $^{3}$, cada qual com seus diferentes materiais, geometria e técnica de fabricação. $O$ desenvolvimento desses sistemas logicamente passa pelo crivo dos testes "in vivo", tanto em animais ${ }^{5,6}$ como no homem". Uma vez que todos os materiais utilizados no dispositivo e na formulação são biocompatíveis, o ponto mais importante destes estudos é a correlação dos perfis de liberação "in vitro" e "in vivo" para que o funcionamento do dispositivo possa ser realmente controlado, ou seja, é importante se considerar as condições de absorção da droga pelo organismo, o que resulta num atraso para se atingir determinadas concentrações plasmáticas em relação ao que é conseguido "in vitro" 7 . 
1.2 - Polímeros condutores

Os polímeros condutores constituem uma versátil classe de materiais pelo fato de unir características metálicas, como propriedades elétricas, eletrônicas, magnéticas e ópticas com outras características típicas de plásticos, como propriedades mecânicas e processabilidade $^{8,9}$. Outro aspecto importante do polímero orgânico condutor é que estes podem sofrer alterações reversíveis entre estados eletronicamente isolantes $\mathrm{e}$ condutores $^{10}$. O primeiro polímero descoberto desta classe foi o poliacetileno, que naturalmente é isolante (condutividade, $\sigma=10^{-5} \mathrm{~S} / \mathrm{cm}$ ). A exposição do poliacetileno a agentes oxidantes ou redutores provocou um aumento na condutividade de 8 ordens de magnitude. Contudo o poliacetileno em sua forma condutora é instável ao ar, insolúvel e infusível, isso levou à pesquisa de outros polímeros condutores intrínsecos, como a polianilina, polipirrol e politiofeno. Dentre esses a polianilina ganha destaque por várias razões: o monômero é relativamente barato, a polimerização pode ocorrer segundo várias técnicas ${ }^{11}$, a polianilina possui uma boa estabilidade química e apresenta bons níveis de condutividade, além de sua solubilidade tanto na forma condutora quanto na isolante.

\subsection{1 - Polianilinas}

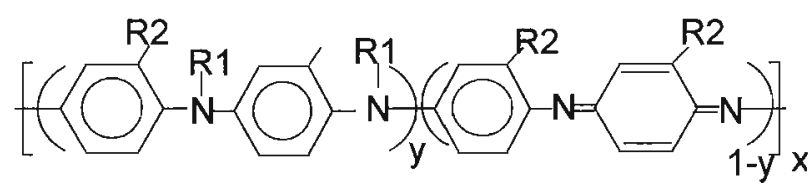

Figura 4 - Estrutura da polianilina e polianilina substituída.

Na Figura 4, é mostrada a estrutura da polianilina, se R1 e R2 forem hidrogênio temos a polianilina, se R1 e R2 forem grupos quaisquer (alquil, em geral), tem-se a polianilina substituída. As características gerais da PANI e da PANI substituída são muito parecidas $^{12}$. Este polímero possui diferentes graus de oxidação, que dependem das porcentagens das espécies reduzidas (y na fórmula acima) e oxidadas (1-y). Se y =1, temos a forma reduzida leucoesmeraldina (amarelo claro), se $y=0.5$, o polímero esta semi-oxidado e se chama esmeraldina (verde), o último estado, $\mathrm{y}=0$, é forma oxidada (violeta) pernigranilina. 
A transformação da polianilina (ou de qualquer outro polímero intrínsicamente condutor) de sua forma isolante para formas condutoras é denominada dopagem. Existem dois processos diferentes de dopagem, a dopagem primária e a secundária.

$\mathrm{Na}$ dopagem primária, um agente oxidante promove a oxidação do sistema $\pi$ de elétrons, como conseqüência temos a formação de cargas positivas na cadeia polimérica, que serão neutralizadas por ânions, ou seja, reações redox são responsáveis pelo aumento da condutividade elétrica no polímero $^{13,14}$.

Já a dopagem secundária é um processo que depende do dopante primário juntamente com o solvente, dito dopante secundário. Este processo aumenta ainda mais a condutividade do polímero, pois aumenta sua cristalinidade, o que faz também aumentar o número de portadores de carga livres deslocalizados ${ }^{15}$.

A forma esmeraldina básica da polianilina (não condutora), sofre dopagem primária ácida, com $\mathrm{HCl}$ em água por exemplo, formando a espécie mais condutora da polianalina, o sal de esmeraldina, como é mostrado na Figura 5. Nesta dopagem a oxiredução é interna, ou seja, o polímero mantém o número de elétrons.

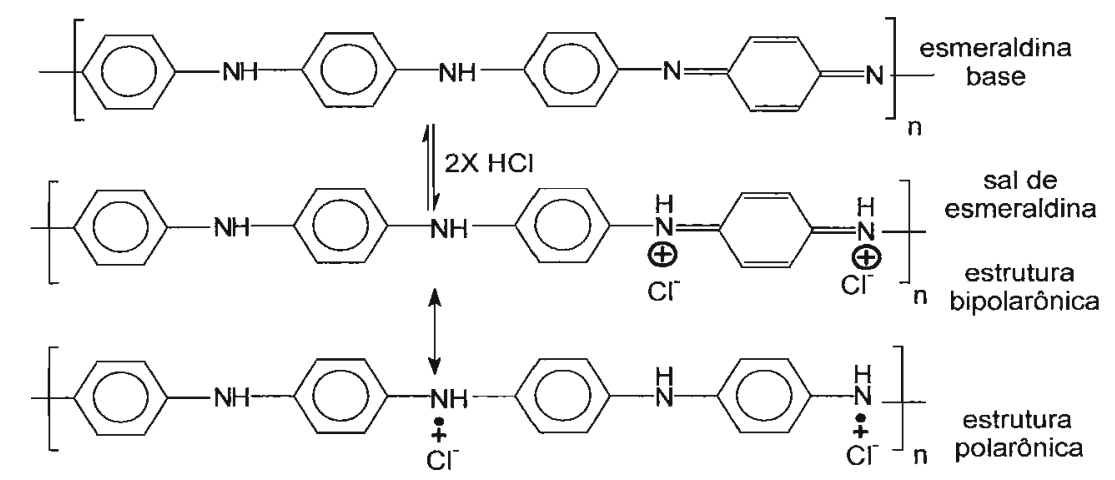

Figura 5 - Dopagem ácida (primária) da polianilina.

Duas propriedades da polianilina, e de outros polímeros condutores, tornam esse tipo de material bastante promissor como superfícies (membranas) controladoras da velocidade de liberação em SLDs: (i) a propriedade de músculo artificial. Foi relatado ${ }^{16}$ uma interessante aplicação da polianilina em SLD, na forma de blenda com o hidrogel poli(2-hidroxi-etil metacrilato), na fabricação de válvulas poliméricas. Como pode ser visto na Figura 6, esses dispositivos funcionam mediante sinais elétricos que controlam o tamanho da abertura de um canal por onde passam as moléculas de droga. 

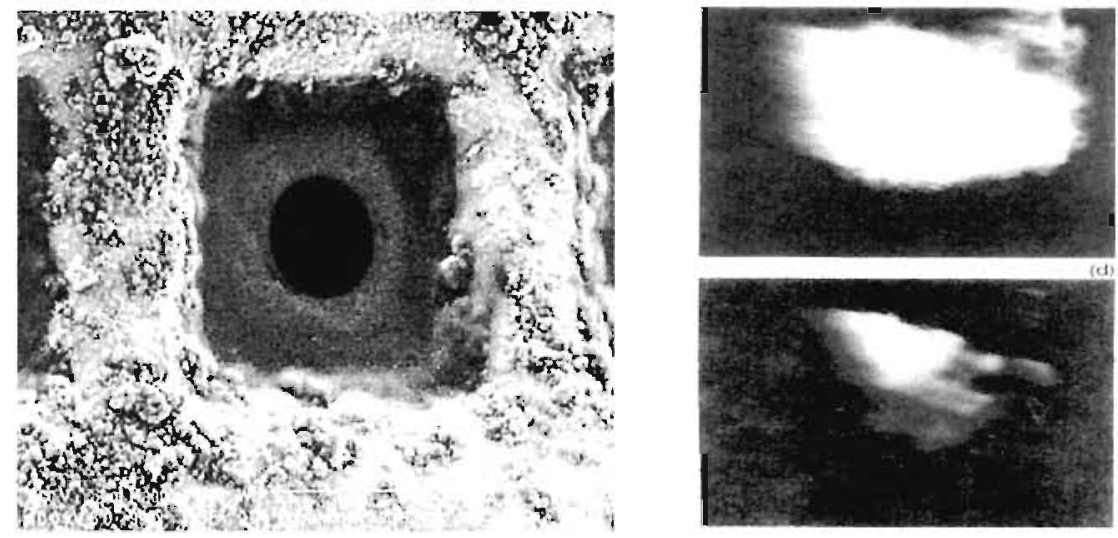

Figura 6 - Esquerda: Microfotografia MEV (microscopia de varredura eletrônica) de polianilina crescida em microeletrodo de grade de ouro recoberto com poli (2-hidroxi etil metacrilato) -válvula polimérica. Direita: Monitoramento in-situ do inchaço (a $+0,3 \mathrm{~V}$ vs ECS), superior, e do encolhimento (a - $0,2 \mathrm{~V}$ vs ECS), parte inferior, da blenda que resulta numa drástica mudança no tamanho da abertura do canal da parte $\mathrm{A}$ - ref. 16 .

(ii) A variação de carga total do polímero frente à mudança de potencial aplicado, ou seja, a variação do estado de oxidação da cadeia polimérica acompanhada por um fluxo de contra íons (a fim de se manter a neutralidade) pode ser usada em sistemas de liberação controlada de drogas, deste que estes contra íons sejam as drogas em questão.

É conhecido que para a polianilina ${ }^{17}$, o processo de compensação de cargas frente uma oxi-redução seja alcançado pelo fluxo de ânions predominantemente. Assim drogas aniônicas podem ser liberadas pelo uso do controle do potencial aplicado ao polímero. Se a necessidade for a de se controlar o fluxo de cátions ao invés de ânions, pode-se pensar na utilização de polianilinas em que o ânion seja grande demais para possuir um fluxo na matriz polimérica uma vez incorporado nela, é o caso da polianilina dopada com ácido dodecilbenzenosulfônico (DBSA), por exemplo. Outro artifício neste sentido é o de se utilizar polianilinas auto-dopadas, como a polianilina sulfonada entre outras $^{18,19}$, nesse caso o grupo $R_{1} / R_{2}$ é o sulfônico, ou seja, o ânion está incorporado no polímero, e somente o cátion pode realizar a compensação de carga.

\subsection{2 - Polímeros condutores aplicados a sistemas de liberação controlada}

A discussão agora será centrada no último mecanismo apresentado na tabela 1 , geralmente chamado de eletroliberação ("eletrorelease") ou liberação controlada eletroquimicamente, o qual representa uma forma simples de se alcançar o controle da liberação. 
Em um artigo apresentado no Third International Symposium on Recent Advances in Drug Delivery Systems, em 1987, L.L. Miller realça as metas de uma pesquisa que desenvolve um modelo de dispositivo eletroquímico para a liberação controlada de material bioativo: "tal dispositivo deve permitir velocidades de liberação variáveis e ter uma capacidade de ligar e desligar."

Miller foi o primeiro em $1984^{20}$, a propor este tipo de abordagem, devido à sua prévia experiência com a liberação de um neurotransmissor ${ }^{21}$, que estava covalentemente ligado a um polímero convencional e assim foi mantido até a aplicação de um pulso de corrente catódica. A partir daí surgiu a hipótese de que maiores quantidades do material poderiam ser prontamente liberadas usando um polímero condutor ao invés do polímero previamente utilizado. Essa habilidade de um polímero condutor ligar/liberar drogas que sejam iônicas é dependente do potencial. O polímero na sua forma condutora (estado oxidado) é positivamente carregado, e para se manter a neutralidade é necessária a presença de contra-íons (dopantes). Num outro extremo, pode-se reduzir o polímero, tornando-o neutro e transformando-o na sua forma isolante, o que exige a saída daqueles contra-íons da matriz polimérica. Então uma mudança na carga total de um polímero redox durante sua redução ou oxidação requer um fluxo de íons para fora ou para dentro da matriz polimérica, e é este processo que permite a ligação/liberação de drogas iônicas em resposta a um sinal elétrico.

O polímero condutor mais amplamente estudado para esta finalidade é o polipirrol, devido ao grande conhecimento de suas propriedades eletroquímicas, a sua estabilidade química e a sua biocompatibilidade.

Voltando à experiência pioneira de Miller, temos que um resumo desta se faz importante, já que mostra o porque do sucesso deste tipo de aplicação e é referência obrigatória em qualquer trabalho em eletroliberação. Polipirrol foi o polímero escolhido, polimerizado anodicamente sobre um eletrodo de carbono vítreo. Como dopantes foram utilizados o ferrocianeto ou o glutamato. A liberação de glutamato (Glư) é de interesse para a neurociência e a eletroatividade do $\mathrm{FeCN}_{6}{ }^{4-}$ provém um conveniente meio para se estudar os filmes condutores e detectar o material excluído após a redução do polímero.

Miller e Zinger observaram a troca de ânions perclorato e glutamato,

$$
\mathrm{PPy}^{+} \mathrm{ClO}_{4}^{-}+\mathrm{Glu}^{-} \rightleftharpoons \mathrm{PPy}^{+} \mathrm{Glu}^{-}+\mathrm{ClO}_{4}^{-}
$$


através de voltametria cíclica do eletrodo recoberto após redução/oxidação com pulsos de potencial. Esta observação inicial conduziu a quantificação do glutamato liberado por pulsos catódicos de 2 minutos, e a quantidade encontrada foi 200 vezes maior do que havia sido conseguido para a liberação de Glu usando um dispositivo com polímero convencional $^{21}$. Em experimentos de controle eles verificaram que sem a aplicação do pulso não havia liberação apreciável de glutamato.

Já na liberação de ferrocianeto, a quantidade do ânion liberada foi acompanhada pela integração dos picos de corrente de voltamogramas. Um ponto interessante foi o comportamento voltamétrico do $\mathrm{PPy} / \mathrm{FeCN}_{6}{ }^{4-} / \mathrm{FeCN}_{6}{ }^{3-}$ em função da espessura do filme (ס). Quando $0.1<\delta<1 \mu \mathrm{m}$, o pico de corrente aumenta linearmente com a espessura do filme e os potenciais dos picos de oxidação e redução permanecem constantes. Quando a espessura do filme excede $1 \mu \mathrm{m}, \mathrm{o} \mathrm{E}^{0}$ permanece aproximadamente constante, mas $\mathrm{E}_{\mathrm{p}}$ aumenta e os picos de corrente são menores do que os previstos pela correlação linear. Com pulsos de potencial por $2 \mathrm{~min}$, Miller e Zinger demonstraram a exclusão dos $\mathrm{FeCN}_{6}{ }^{4-/ 3-}$ durante a redução do filme pelo desaparecimento das ondas voltamétricas do par redox $\mathrm{FeCN}_{6}{ }^{4-} / \mathrm{FeCN}_{6}{ }^{3-}$.

Miller quantificou o $\mathrm{FeCN}_{6}{ }^{4-}$ através de voltamogramas de filmes de várias espessuras, e verificou que a quantidade de material liberada era proporcional à espessura, enquanto esta era $<1 \mu \mathrm{m}$.

Outra importante abordagem destes pesquisadores foi a aplicação de pulsos curtos ao eletrodo, verificaçando assim a "última meta" de um controle quantitativo: após cada pulso de $\quad-0.8 \mathrm{~V}$ por $1 \mathrm{~s}$, a voltametria cíclica revelou que a quantidade de $\mathrm{FeCN}_{6}{ }^{4-}$ liberada aumentava de um valor constante até mais ou menos o $12^{0}$ pulso. A quantidade total do íon liberada depois destes 12 pulsos estava em concordância com a quantidade encontrada antes para um pulso de 2 minutos. Além disso, não houve evidências de liberação espontânea, ou seja, o ferrocianeto não deixou o polímero sem aplicação de um estímulo eletroquímico.

Estes resultados claramente demonstraram que o polipirrol pode ser eletricamente controlado para liberar quantitativamente quantidades específicas de ânions.

A despeito do sucesso da metodologia, e da idade desta publicação, uma busca minuciosa na literatura mostra que não há um grande número de trabalhos sobre eletroliberação utilizando polímeros condutores. Dessa forma, apesar da polianilina ser 
candidata a tal aplicação, por ser um dos polímeros condutores mais estudados (além de não ser tóxico), foi explorada poucas vezes em sistemas de liberação controlada, por exemplo: de uma maneira que se beneficia de suas propriedades viscoelásticas (músculo artificial) num dispositivo mais mecânico do que elétrico ${ }^{16}$ e através dos estudos de Massoumi, com sistemas bicamadas na eletroliberação de ácido sulfosalicílico ${ }^{22}$.

Mesmo com essa ressalva, pode-se voltar ao caso do uso do polipirrol como membrana modelo onde se tem, por parte de alguns poucos grupos de pesquisa, outros exemplos de eletroliberação de ânions. Kontturi e cols. ${ }^{23}$ mostraram, usando dados de microbalança de quartzo, a possibilidade da liberação controlada de nicosídeo, naproxen e salicilato entre outras drogas, chamando a atenção para a estabilidade da membrana em soluções contendo $\mathrm{Cl}^{-}$e para o quanto a estrutura e o tamanho do ânion tem que ser considerado para a eficiência do processo.

Kontturi mostrou também a importância do procedimento de polimerização da membrana na liberação de ânions. Exemplificando com outro trabalho ${ }^{24}$ pode-se dizer que membranas eletropolimerizadas com uma baixa velocidade - até $1 \mathrm{mAcm}^{-2}$ - são mais densas e uniformes e fornecem resultados mais reprodutíveis; porém são capazes de armazenar ou carregar menor quantidade de droga. Por outro lado, membranas polimerizadas a altas velocidades - acima de $5 \mathrm{mAcm}^{-2}$ - carregam mais droga. Outro ponto levantado por Kontturi, e intimamente ligado a essa escolha de como sintetizar a membrana, é a séria limitação, considerando uma aplicação prática, da quantidade de medicamento (da ordem de dezenas de nmolares) que pode ser liberada usando estes dispositivos. Huang ${ }^{25}$ trabalhando com o ânion 5-FU, um anti-cancerígeno, também relata o mesmo tipo de limitação.

Pyo e Reynolds ${ }^{26,27}$ demostraram que a liberação controlada de adenosina trifosfato (ATP), uma das mais importantes moléculas na transferência de energia em processos metabólicos, pode ser conseguida usando somente poli(pirrol adenosina 5'trifosfato) ou sistemas de membranas bicamadas, onde compósitos de PPy/PSS polipirrol/ poli(sulfonato de estireno) contituem a membrana interna e poli(metilpirrol) é a camada externa.

Até aqui foi citado somente o mecanismo de liberação aniônica, considerando que o esqueleto polimérico oxidado é positivamente carregado. Assim fica claro que numa redução do polímero (tornando-o neutro) teremos a saída de ânions preferencialmente à entrada de cátions para a neutralização de cargas. Porém se houver o interesse de se inverter a situação, de modo que o fluxo dominante seja catiônico, num 
processo de oxidação, há a necessidade de utilizar ânions que não tenham mobilidade uma vez incorporados no polímero condutor. Isto pode ser alcançado usando-se compósitos, onde temos um poliânion como contra-íon do polímero condutor. Dessa forma M. Hepel $^{28}$ conseguiu acompanhar, com um sensor piezoelétrico, a liberação controlada de cloropromazina, uma droga neuroléptica catiônica, usando filmes de polipirrol/melanina. A melanina é um biopolímero polifuncional carregado negativamente (grupos - $\mathrm{COO}^{-}$) que não se separa do polipirrol mesmo depois de repetidas ciclagens de potencial. Miller e cols. ${ }^{29}$ também sintetizaram um compósito polimérico (poli( $N$-metilpirrol)/poli(sulfonato de estireno)) capaz de controlar a liberação de dopamina protonada.

Como citado nos exemplos anteriores, a microbalança eletroquímica a cristal de quartzo (MECQ) é uma importante ferramenta para acompanhar o fluxo iônico, através da variação da freqüência da vibração fundamental do cristal, quando seu depósito metálico está recoberto com um polímero condutor e este sofre um processo redox. Existe uma relação direta entre a variação de freqüência e a variação de massa (equação de Sauerbrey) que permite calcular a quantidade de droga liberada ${ }^{27,28}$. A MECQ além de quantificar é útil para estabelecer como cátions e ânions fluem na matriz polimérica para compensar a carga. Outras técnicas com o propósito puramente analítico como $\mathrm{HPLC}^{23}, \mathrm{ECZ}$ (eletroforese capilar por zona) ${ }^{27}$ e espectroscopia no UV-Visível ${ }^{24,26,28}$ também tem sido usadas em sistemas de liberação controlada.

O mecanismo de liberação com polímeros condutores pode ser disparado por um sinal eletroquímico como foi visto até agora, ou de outra maneira que pode ser mais interessante do ponto de vista biomédico: um dispositivo de liberação auto-regulada. Pernaut e Reynouds ${ }^{24}$, demonstraram a eficiência da liberação de ATP acionada pela redução química do polipirrol por hidrazina $\left(\mathrm{N}_{2} \mathrm{H}_{4}\right)$, porém houve uma diminuição na cinética de liberação e na quantidade liberada quando comparado ao processo eletroquímico ( $20 \%$ a menos de ATP foi liberado). Por outro lado experimentos com auto-regulação controlada pelo $\mathrm{pH}$ (liberação acionada pela desprotonação do filme) mostram um processo mais rápido do que o eletroquímico com um perfil de liberação com características de cinética de ordem zero. Ou seja, modificações de um microambiente fisiológico podem servir para acionar mecanismos de liberação utilizando polímeros condutores.

Como exemplo mais recente do uso de polímeros condutores no controle da liberação de drogas, pode-se citar o trabalho de M. Madou ${ }^{30}$, que utilizando uma 
membrana flexível de Au/polipirrol/DBS propôs a fabricação de válvulas que controlam eletroquimicamente a abertura de reservatórios que contem a droga a ser liberada. A Figura 7 ilustra este funcionamento, motrando o reservatório aberto (sistema oxidado) e fechado (sistema reduzido), a propriedade de músculo artificial dos polímeros ${ }^{31}$ condutores garante a movimentação de filmes finos de polímeros condutores como já foi amplamente demostrado numa série de trabalhos ${ }^{32-34}$ : neste exemplo, quando o sistema está reduzido, íons sódio, com sua camada de solvatação estão no interior da matriz de polipirrol, sendo este o estado de maior volume do material que recobre o reservatório; porém, quando se oxida o polímero condutor, este (como esta dopado com íons $\mathrm{DBS}^{-}$grandes e imóveis na matriz polimerica ${ }^{35}$ ) expulsa íons sódio e água de sua matriz levando-o a um estado de menor volume, o que em ultima instância contrai o filme e abre o reservatório. Uma vantagem deste tipo de sistema é que nele podem ser empregadas formulações sólidas ou líquidas.

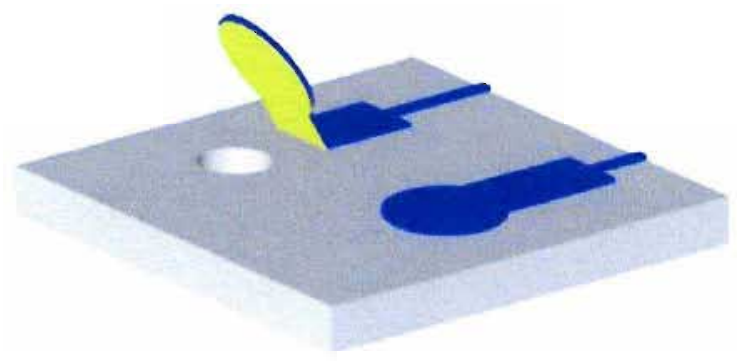

Figura 7 - Esquema de funcionamento de uma válvula baseada num filme de $\mathrm{Au} /$ polipirrol/DBS que controla a abertura de um reservatório de drogas. Ref. 30.

\subsection{3 - Biocompatibilidade de polímeros condutores}

Como nesta tese se propõe a utilização de polímeros condutores em sistemas de liberação controlada de drogas, e tais sistemas teriam que ser transdérmicos ou implantes, é importante assegurar que os polímeros condutores sejam biocompatíveis.

A biocompatibilidade de um material polimérico usado em implantes é basicamente avaliada pelas suas interações interfaciais com proteínas plasmáticas, proteínas em fluídos biológicos e plaquetas ${ }^{36,37}$. É conhecido que proteínas podem ser adsorvidas em praticamente toda superfície e interface durante os primeiros minutos de exposição a fluídos biológicos e ao sangue ${ }^{38,39}$. Geralmente, este processo de adsorção 
resulta em adesão de plaquetas (e ativação do mecanismo de coagulação), ocasionando a formação de trombose.

As aplicações de polímeros condutores eletroativos no campo de biossensores fizeram com que se estudassem sua biocompatibilidade ${ }^{40-42}$. Antes de se avaliar a adsorção de proteínas e plaquetas em polímeros condutores (polianilina e polipirrol) ${ }^{40,41}$, Wang e cols. ${ }^{42}$ mostraram resultados sobre testes de implantes de polianilina em tecido de ratos (Sprague Dawley) vivos. Polianilina na forma de pó e filme de esmeraldina básica, nigranilina e leucoesmeraldina e filmes de esmeraldina básica modificados pela copolimerização (gerando um polímero grafitizado) com ácido acrílico e subsequente imobilização de colágeno por ligação covalente, foram implantados em ratos por um período de 19 a 50 semanas. A análise histológica dos tecidos mostrou que não houve significativa inflamação depois de 50 semanas de implante. Porém na mesma análise verificou-se que filmes de esmeraldina foram encapsulados por vários tecidos fibrosos dispersamente arranjados, já a polianilina modificada com colágeno não apresentou indícios de incompatibilidade com o tecido próximo ao implante.

Exames envolvendo a oxidação de hematoxilina e eosina não mostram sinais de anormalidade na região adjacente ao implante. Todavia, células do sistema imunológico não foram observadas.

A análise por XPS do polímero condutor não revelou nenhuma alteração estrutural após o implante, a não ser alterações espectrais devido à hidrólise da polianilina depois de uma prolongada exposição a meio aquoso ${ }^{43}$.

Testes com albumina mostraram que filmes de esmeraldina base adsorvem cerca de $0,95 \mu \mathrm{gcm}^{-2}$ de proteína. A modificação da superfície da polianilina por grafitização de poli(etileno glicol), induzida por radição UV, reduz para um mínimo de $0,33 \mu \mathrm{gcm}^{-2}$ de proteína adsorvida. Extensiva adesão de plaquetas sobre a polianilina foi verificada através de imagens $\mathrm{MEV}$, porém a mesma modificação na sua superfície reduziu drasticamente as plaquetas sobre o polímero ${ }^{40}$. Resultados similares foram obtidos com o polipirrol, ou seja, a modificação de sua superfície com poli(etileno glicol) também diminui a adsorsão de proteínas e a adesão de plaquetas ${ }^{41}$. A protonação da polianilina modificada diminui ainda mais as proteínas em sua superfície ${ }^{40}$. Tanto a polianilina quanto o polipirrol tem sua biocompatibilidade aumentada pela copolimerização de poli(etileno glicol) em sua superfície, de forma que tais polímeros se tornam biomateriais com um maior potencial para aplicações "in vivo" 40. 
1.3 - Hidrogéis e sua aplicação em liberação controlada de drogas

BIBLIOTECA INSTITUTO DE QUIMICA Universidade de São Paulo

O projeto de um sistema de liberação de drogas é usualmente baseado nas propriedades físico-químicas e farmacocinéticas da droga. Os sistemas de liberação convencionais sofrem as limitações da mínima sincronização entre o tempo necessário para se atingir concentrações terapeuticamente efetivas da droga no plasma e o perfil de liberação exibido pela forma de dosagem.

Uma maior compreensão do conceito de cronofarmacocinética e variações nos sintomas das doenças por causa dos ritmos diurnos fez crescer a importância de sistemas de liberação que sigam as necessidades sintomáticas das doenças ${ }^{44}$. Estas considerações têm mudado o rumo das pesquisas em sistemas de liberação, o foco agora tem sido tornar o fármaco disponível no tempo desejado e no lugar do organismo onde ele agirá.

Neste sentido, os hidrogéis têm emergido como uma opção promissora. Os hidrogéis existem desde 1960, quando Wichterle and Lim propuseram o uso de redes hidrofílicas de poli(2-hidroxietil-metacrilato) (PHEMA) em lentes de contato ${ }^{45}$. Desde então, o uso de hidrogéis tem se estendido para várias aplicações biomédicas ${ }^{46}$ e farmacêuticas ${ }^{47}$. Em comparação com outros biomaterais sintéticos, os hidrogéis se assemelham mais a tecidos vivos, principalmente em suas propriedades físicas, devido ao seu relativamente alto teor de água e consistência maleável e elástica. Hidrogéis mostram mínima tendência em absorver proteínas de fluídos biológicos por causa da sua baixa tensão interfacial. Além disso, a habilidade de moléculas de diferentes tamanhos difundir para dentro (carregamento) e para fora (liberação) dos hidrogéis, permite o possível uso dessas redes poliméricas secas ou intumescidas como sistemas de liberação de drogas em várias formas de administração (oral, nasal, vaginal, ocular, parenteral, etc).

Os hidrogéis são conhecidos como "hidrogéis inteligentes" ${ }^{48}$. Essa denominação significa sua habilidade em receber, transmitir ou processar um estímulo e responder gerando um efeito útil ${ }^{49}$. Uma vez em funcionamento, o estímulo pode resultar em mudanças de fases, formas, propriedades ópticas, mecânicas, velocidades de reações e de permeação. Os hidrogéis são inteligentes no sentido de que eles podem perceber um determinado estímulo e responder mudando suas propriedades físicas e químicas, resultando na liberação de drogas aprisionadas de maneira controlada. 
Um erro comum de interpretação na ciência de polímeros é o uso dos termos "gel" e "hidrogel" como sinônimos. Como redes poliméricas, tanto géis como hidrogéis podem ser quimicamente similares, mas eles são fisicamente distintos. D. J. Lloyd, habilmente descreve os géis como "a condição coloidal, o gel, é aquela que é mais fácil de reconhecer do que definir" 50 .

Tecnicamente, os géis são sistemas semi-sólidos em que pequenas quantidades de sólido estão dispersas em relativamente grandes quantidades de líquido, mesmo assim possuem características mais de sólido do que de líquido ${ }^{51}$. Hidrogéis, às vezes, também são descritos como géis aquosos devido ao prefixo "hidro". Contudo o termo "hidrogel” implica num material já intumescido em água, e numa definição mais rígida, hidrogéis são redes de polímeros hidrofílicos com ligações cruzadas. Eles possuem a habilidade de absorver grandes quantidades de água e intumescer mantendo sua estrutura tri-dimensional. ${ }^{52}$. Como é mostrado na Figura 8 , esta definição diferencia hidrogéis de géis, os quais são redes poliméricas já intumescidas em equilíbrio, e a adição de mais fluídos resulta somente na diluição da rede polimérica. Um hidrogel exibe intumescência em meio aquoso pela mesma razão que um polímero linear análogo se dissolve em água formando uma solução polimérica. Então a característica central para o funcionamento (e existência) de um hidrogel são suas ligações cruzadas. Devido à estrutura básica de géis e hidrogéis serem as redes poliméricas, estes polímeros geram sistemas que se estendem por uma faixa de rigidez, começando com um sol, passando por géis, chegando aos hidrogéis.

Um hidrogel é considerado como um material polimérico capaz de absorver > $20 \%$ do seu peso em água mantendo sua estrutura tri-dimensional. A hidrofilicidade do polímero confere suas propriedade de intumescimento em água. Sua insolubilidade em água é atribuída à presença de ligações (químicas ou físicas) cruzadas, as quais conferem uma estrutura de rede e integridade física ao sistema. Hidrogéis são elásticos por natureza por causa da presença de uma configuração de referência memorizada para a qual ele retorna mesmo depois de longos períodos de deformação. 


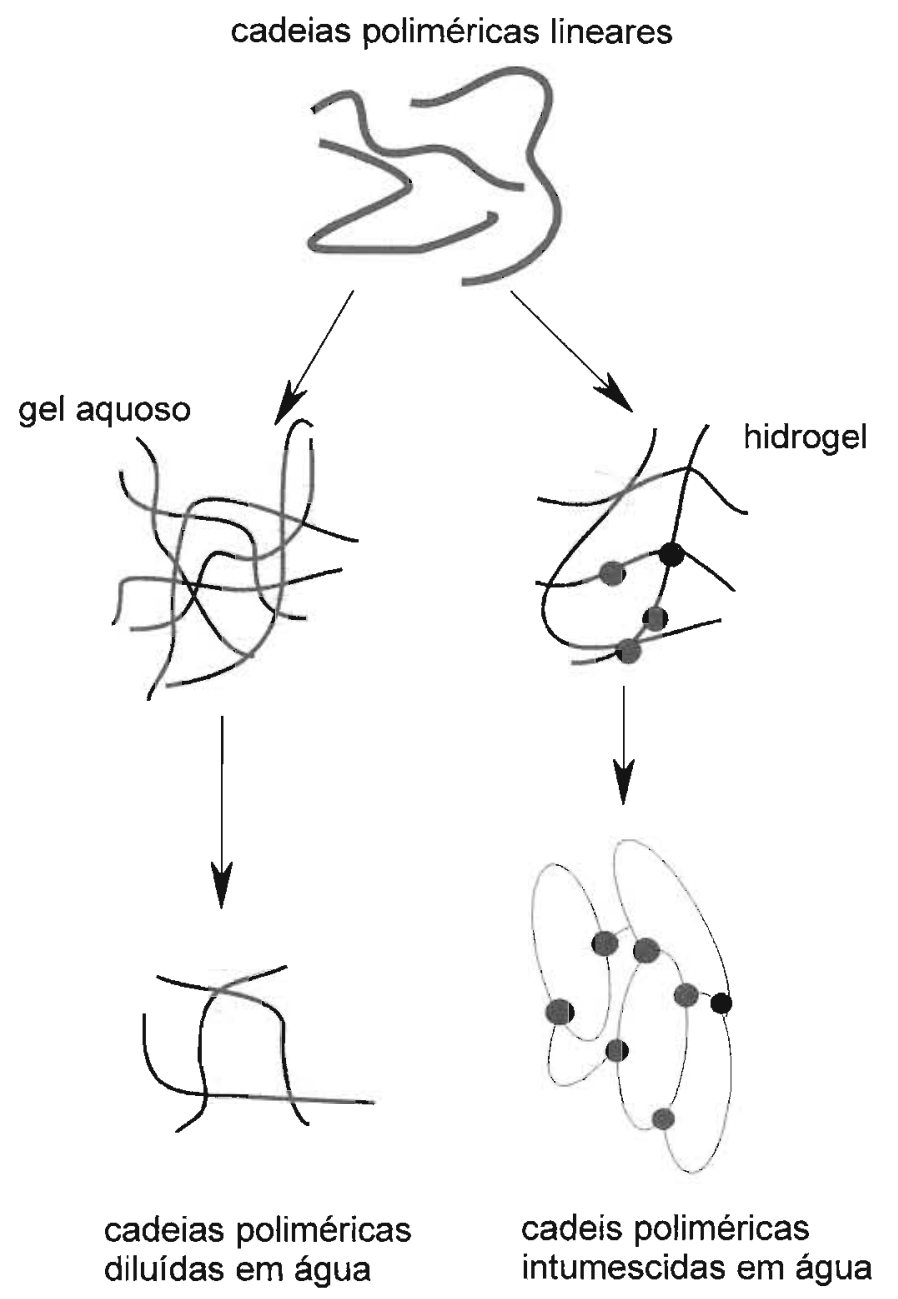

Figura 8 - Cadeias poliméricas formando um gel e um hidrogel, mostrando os diferentes comportamentos em água. Os círculos sólidos representam ligações cruzadas covalentes entre as cadeias e os círculos vazios representam ligações cruzadas virtuais formadas pelo emaranhado de cadeias. Adaptado da ref. 53.

$\mathrm{Na}$ verdade, hidrogéis são polímeros que combinados com água, criam um sólido com propriedades parecidas com as da água, como a permeabilidade de muitas substâncias. Tradicionalmente sistemas de liberação controlada são classificados como tipo reservatório, tipo matriz e híbridos reservatório/matriz (ver seção 1.1.2). Embora melhores resultados sejam obtidos com matrizes poliméricas, tais sistemas tendem a seguir o modelo de Higushi ${ }^{54}$, o qual diz que a droga liberada é proporcional à raiz quadrada do tempo de liberação. Este comportamento leva a velocidades de liberação não-uniformes. A grande vantagem do uso de hidrogéis em SLDs são velocidades de liberação mais constantes ${ }^{54}$.

Polímeros de fontes naturais, sintéticas ou semi-sintéticas podem gerar hidrogéis. Mais tradicionalmente, polímeros contendo grupos funcionais como hidroxil, amina, 
amida, éter, carboxilato e sulfonato nas cadeias laterais são usados na síntese de hidrogéis. $\mathrm{O}$ carregamento da droga no hidrogel pode ser realizado junto com a etapa de polimerização/cruzamento das cadeias ou depois do hidrogel pronto e seco, promovendo o intumescimento numa solução aquosa contendo a droga.

A maioria dos hidrogéis são vítreos na sua forma desidratada, e a liberação da droga geralmente envolve simultaneamente, a adsorção de água e desorção da droga por um mecanismo controlado pela velocidade de intumescimento do polímero.

Sistemas de liberação controlada são normalmente insensíveis às mudanças metabólicas do organismo. Para sincronizar o perfil de liberação com as condições fisiológicas, materiais e mecanismos que respondam a tais condições têm sido desenvolvidos. Um bom exemplo da necessidade desta sincronização entre dosagem/sintomas é a diabete, já que sistemas que liberam insulina em resposta ao nível de glicose no sangue melhoram muito a condição do diabético. Os hidrogéis, por sua vez, são excelentes materiais que respondem aos mais diversos estímulos (internos ou externos ao corpo), exibindo dramáticas mudanças na sua velocidade e grau de intumescimento, estrutura da rede e permeabilidade. Vários sistemas já foram descritos com essa finalidade e a tabela 2 traz alguns exemplos de aplicação de hidrogéis em sistemas de liberação de drogas que respondem a estímulos.

Tabela 2 -Hidrogéis ativados por estímulos em liberação controlada de drogas

\begin{tabular}{cccc}
\hline estímulo & polímero & droga & ref. \\
campo magnético & etileno-co-acetato de vinila (EVA) & insulina & 55 \\
ultrassom & EVA & insulina & 56 \\
campo elétrico & poli(2-hidroxietil metacrillato) & propranolol & 57 \\
glicose & (PHEMA) & insulina & 58 \\
uréia & EVA & hidrocortisona & 59 \\
morfina & éter metil vinílico-co-anidrido & & \\
manticorpos & poleico & naltreoxona & 60 \\
pH & maleico & estradiol & 61 \\
temperatura & poli( $N$-isopropilacrilamida) & heparina & 63 \\
\hline
\end{tabular}




\section{2-Objetivo}

Esta tese de doutorado tem como objetivo o estudo de novos sistemas poliméricos baseados em polímeros condutores e hidrogéis como modelos para dispositivos de liberação controlada eletroquimicamente de drogas. 


\section{3 - Parte experimental}

\section{1 - Materiais}

Todos os reagentes foram utilizados como recebidos, com exceção à anilina e ao pirrol que foram destilados antes do preparo das soluções. As soluções aquosas foram preparadas com água deionizada (Elga System UHQ, $\sigma=0,5 \mathrm{nS} . \mathrm{cm}^{-1}$ ) A tabela 3 mostra os reagentes/materiais utilizados e sua procedência. $\mathrm{N}_{2}$ (Air Products) foi utilizado para desoxigenar as soluções, quando descrito na seção de 'resultados e discussões'.

Tabela 3 - Reagentes utilizados

\begin{tabular}{|c|c|}
\hline Reagente & Procedência \\
\hline Ácido clorídrico & Synth \\
\hline Ácido metanílico, $99 \%$ & Aldrich \\
\hline Ácido sulfúrico & Synth \\
\hline Acrilamida, $99 \%$ & Aldrich \\
\hline Álcool etílico Absoluto & Synth \\
\hline Anilina, 99\% & Aldrich \\
\hline Cloreto de potásssio & Synth \\
\hline DBSA & Tókio Kasei \\
\hline Dopamina protonada (sal de cloreto) & Acros Organics \\
\hline Hidróxido de amônio & Synth \\
\hline MBA & Sigma \\
\hline Náfion (solução alcoólica 5\% v/v) & Aldrich \\
\hline Nevirapina & Cipla \\
\hline$N$-metilpirrol, $99 \%$ & Aldrich \\
\hline Perclorato de lítio & Aldrich \\
\hline Peroxidissulfato de potássio & Merck \\
\hline Pirocatecol violeta & Sigma \\
\hline Pirrol, 98\% & Aldrich \\
\hline $\begin{array}{l}\text { Poli(4-estireno sulfonato de sódio) } \\
\qquad \mathrm{M}_{\mathrm{w}}=70.000\end{array}$ & Aldrich \\
\hline
\end{tabular}




\begin{tabular}{cc}
\hline Safranina & Merck \\
Salicilato de sódio (grau anlitico) & Merck \\
TEMED & Aldrich \\
Tetraciclina (Tetramax) & Luper Industria farmacêtica \\
\hline
\end{tabular}

\section{2 - Instrumentação}

Medidas de $\mathrm{pH}$ foram realizadas em $\mathrm{pHmetro}$ com eletrodo combinado de vidro da Digimed. O polimento dos eletrodos foi feito com polidora Arotec APL4. Sínteses e experimentos eletroquímicos foram realizados utilizando dois modelos diferentes de potenciostato/galvanostato: um EG\&G PAR modelo 362 interfaciado com software da National Instruments e um Eco Chemie - Autolab/PGSTAT30. Espectros de absorbância foram feitos num espectrofotômetro HP/Agilent 8453 com arranjo de diodos.

A microscopia/espectroscopia Raman foi realizada no Laboratório de Espectroscopia Molecular/IQ-USP com um Microscópio Raman Renishaw 3000 equipado com detector CCD (Wright 600x400 pixels), refrigerado termoeletricamente e microscópio metalúrgico Olympus BH2-UMA (lente 50X).

Primeiramente foi realizada a microscopia de força atômica no Laboratório de Filmes Finos/IF-USP com um "Scanning Probe Microscope" da Digital Instruments, denominado NanosCope IIIA, posteriormente em nosso laboratório com um microscópio da Molecular Imaging - modelo PicoScan 2100.

Medidas de massa e densidade dos hidrogéis foram realizadas numa balança Mettler Toledo AG285 equipada para determinações de densidade de líquidos e sólidos. Cromatografia por exclusão de tamanho foi realizada em um cromatógrafo Shimadzu Class-LC10 equipado com um detector UV-Vis SPD-10A (254 nm). As amostras passaram por uma seqüência de quatro colunas ultra-hydrogel (Waters) de 2000, 500, 250, 120 Angstrons de porosidade. Foram utilizados padrões de PEO de 860000, 348000,24800 e $18200 \mathrm{~g} \cdot \mathrm{mol}^{-1}$.

Imagens de microscopia eletrônica foram realizadas no Laboratório de Microscopia Eletrônica (LME) situado no Laboratório Nacional de Luz Sincrotron (LNLS-Campinas) e obtidas com a utilização de um Microscópio Eletrônico de Varredura JSM $5900 \mathrm{LV}$ da Jeol. Quando necessário para a realização de imagens no 
modo de alto vácuo do microscópio, as amostras eram recobertas com um filme fino de ouro com a utilização de um "Sputter Coater" SCD 050 da Bal-Tec.

Imagens de microscopia óptica foram obtidas de um Microscópio Olympus BX51M com aquisição digital através de uma câmera CCD Micropublisher 3.3RTV da Q-Imaging.

\section{3 - Metodologia}

\subsection{1 - Eletroquímica}

Todos os experimentos eletroquímicos foram realizados em célula convencional de três eletrodos. O eletrodo auxiliar foi um fio de $\mathrm{Pt}$, limpo antes de cada experimento por exposição à chama de um bico de bunsen. Os potenciais foram referidos sempre ao eletrodo de calomelano saturado. O eletrodo de trabalho na síntese de filmes de polímeros condutores foi um disco de platina (área $=0,0531 \mathrm{~cm}^{2}$ ) embutido em corpo de teflon e na síntese de compósitos de polímero condutor/hidrogel foi um fio de Pt.

\subsection{2 - Preparação dos filmes poliméricos}

\subsubsection{1 - PANI/Náfion}

A camada de polianilina foi crescida potenciodinamicamente (voltametria cíclica de $-0,2 \mathrm{~V}$ a $0,8 \mathrm{~V}, 50 \mathrm{mVs}^{-1}$ ) e o número de ciclos foi a variável estudada. A solução de síntese era desoxigenada e continha $0,5 \mathrm{moll}^{-1}$ de anilina e $1,0 \mathrm{molL}^{-1} \mathrm{HCl}$ em água. Após a síntese do polímero condutor, o eletrodo era recoberto com uma solução (água e mistura de álcoois, $5 \% \mathrm{~m} / \mathrm{m}$ ) de Náfion por "casting" de $4 \mu \mathrm{L}$ de solução contendo o polímero. Finalmente a membrana era polarizada a $0,2 \mathrm{~V}$ em solução aquosa de $\mathrm{HCl} 0,1$ molL ${ }^{-1}$ durante 20 minutos.

\subsubsection{2 - Polipirrol}

Filmes de polipirrol dopado com $\mathrm{DBS}^{-}$foram preparados potenciostaticamente $(0,7 \mathrm{~V})$ em solução contendo $50 \mathrm{mmolL}^{-1}$ de pirrol e $20 \mathrm{mmolL}^{-1}$ de $\mathrm{DBS}^{-}$. Filmes de polipirrol dopado com PSS $^{-}$foram sintetizados da mesma forma, porém substituindo o 
DBSA por PSS$^{-} 5 \%$ (em massa) na solução de síntese. A espessura dos filmes foi controlada pela carga passada no sistema.

\subsection{3 - Espectrofotometria UV-Vis}

Os espectros de absorbância foram obtidos de soluções contidas em cubeta de quartzo com caminho óptico de 1,0 cm. Devido a imprecisão do aparelho nas medidas de absorção de analitos em baixa concentração $\left(1,0.10^{-4}-5,0.10^{-6} \mathrm{molL}^{-1}\right)$, usou-se um recurso de correção da linha base pela subtração de todo espectro por um valor médio de absorbância correspondente a uma região do espectro onde tal analito não absorve.

\subsection{4 - Carregamento dos filmes poliméricos e liberação controlada}

Para o sistema PANI/Náfion, o carregamento foi realizado em solução aquosa contendo $0,1 \mathrm{molL}^{-1}$ de dopamina por polarização do eletrodo modificado a $0,05 \mathrm{~V}$ por 10 minutos. A liberação era realizada em solução aquosa de $\mathrm{HCl} 0,1 \mathrm{molL}^{-1} \mathrm{e}$ acompanhada por espectrofotometria UV-Vis.

Filmes de polipirrol foram carregados com lítio por voltametria cíclica ou polarização, em solução aquosa de perclorato de lítio $1,0 \mathrm{molL}^{-1}$. A liberação ocorreu em solução aquosa de $\mathrm{KCl} 0,1 \mathrm{molL}^{-1}$. Alíquotas de $200 \mu \mathrm{L}$ da solução de liberação eram retiradas durante o experimento para quantificação do $\mathrm{Li}^{+}$por emissão atômica. $\mathrm{O}$ volume da solução foi mantido constante durante a liberação e o número de mols utilizado na construção dos perfis de liberação foi corrigido considerando esta diluição.

Detalhes da síntese de filmes de polianilina utilizados na liberação de ácido salicílico são dados na seção 4.2.1.

Os teste de liberação controlada de dopamina e ácido salicílico a partir das membranas poliméricas foram realizados 'in situ', como pode ser visto no esquema da Figura 9: a célula eletroquímica foi montada numa cubeta de quartzo e espectros da solução de liberação em função do tempo de aplicação do sinal elétrico (potencial) foram registrados. $O$ volume na célula de liberação foi sempre de $2,0 \mathrm{~mL}$. A agitação da solução foi feita com um pequeno agitador magnético e um imã acoplado a um motor elétrico. Ao se emparelhar o imã na parede lateral da cubeta conseguiu-se uma forma de agitação que não interferia na medida. Tal montagem foi possível devido à configuração do espectrofotômetro, que é aberto entre a fonte luminosa e o detector. 

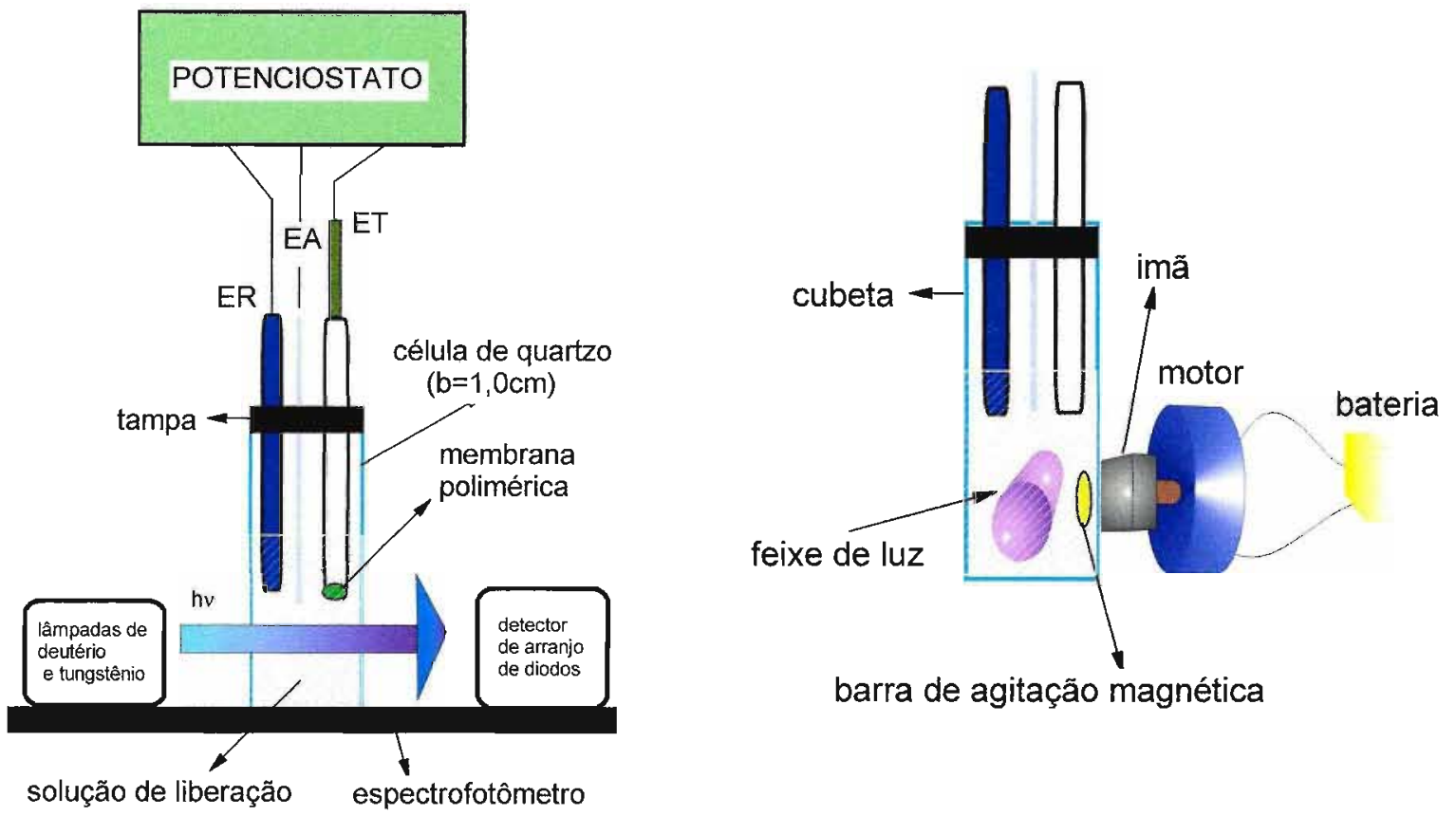

Figura 9 - Arranjo experimental para os testes de liberação controlada. Esquerda: vista lateral. Direita: vista frontal, destacando a montagem para a agitação magnética.

\subsection{5 - Síntese dos hidrogéis de poliacrilamida e poliacrilamida não-reticulada}

Onze hidrogéis de diferentes composições (tabela 4) foram preparados como descrito por Wallace ${ }^{64}$ a acrilamida e a N,N'-metileno-bis-acrilamida (MBA) foram adicionadas à água deionizada. Depois da solução ser purgada com $\mathrm{N}_{2}$ durante $10 \mathrm{~min}$, N,N,N',N'- tetrametiletilenodiamina e peroxidissulfato de potássio foram adicionados sob rigorosa agitação magnética. A temperatura ambiente, a gelificação ocorre tipicamente depois de 10 minutos.

Também foram sintetizadas seis diferentes poliacrilamidas (tabela 5) para 0 estudo de cromatografia por exclusão de tamanho. A síntese é idêntica à dos hidrogéis, porém sem a adição do agente promotor de ligações cruzadas (MBA).

Tabela 4 - Composição dos hidrogéis de poliacrilamida estudados.

\begin{tabular}{ccccccc}
\hline Hidrogel & AAM / g & MBA /g & TEMED / $\boldsymbol{\mu L}$ & Peroxidissulfato /g & $\%$ T & $\mathbf{\% C}$ \\
\hline $\mathbf{1}$ & 0,10 & 0,0030 & 10 & 0,0010 & 10 & 3 \\
$\mathbf{2}$ & 0,05 & 0,0026 & & & 5 & 5 \\
$\mathbf{3}$ & 0,15 & 0,0076 & & 15 & 5 \\
$\mathbf{4}$ & 0,20 & 0,0100 & & 20 & 5 \\
\hline
\end{tabular}




\begin{tabular}{ccccc}
\hline $\mathbf{5}$ & 0,25 & 0,0130 & 25 & 5 \\
$\mathbf{6}$ & 0,30 & 0,0160 & 30 & 5 \\
$\mathbf{7}$ & 0,10 & 0,0050 & 10 & 5 \\
$\mathbf{8}$ & 0,20 & 0,0170 & 20 & 8 \\
$\mathbf{9}$ & 0,20 & 0,0220 & 20 & 10 \\
$\mathbf{1 0}$ & 0,30 & 0,0330 & 30 & 10 \\
\hline $\mathbf{1 1}$ & 0,20 & 0,0270 & 20 & 12 \\
\hline
\end{tabular}

Obs.: Volume final $=1,0 \mathrm{~mL}$. Ver apêndice para a definição de $\% \mathrm{C} \mathrm{e} \% \mathrm{~T}$.

Tabela 5 - Quantidades utilizadas nas polimerizações sem MBA.

\begin{tabular}{cccc}
\hline poliacrilamida & AAM /g & TEMED / $\mu \mathrm{L}$ & Peroxidissulfato / g \\
\hline 1 & 0,5 & & \\
2 & 1,0 & 100 & 0,0100 \\
3 & 1,5 & & \\
4 & 2,0 & & \\
5 & 2,5 & & \\
\hline 6 & 3,0 &
\end{tabular}

Obs.: Volume final $=10,0 \mathrm{~mL}$.

3.3.6 - Medidas de massa e densidade dos hidrogéis sintetizados

Quatro amostras diferentes para cada hidrogel sintetizado foram utilizadas para determinação de massa e densidade no estado de intumescimento máximo e no estado relaxado (seco). As amostras foram secas em estufa a $60^{\circ} \mathrm{C}$ até atingirem massa constante.

3.3.7 - Matrizes para a síntese dos compósitos hidrogel / polímero condutor

As mesmas condições e quantidades de reagentes já descritas foram utilizadas também para sintetizar os hidrogéis para formação dos compósitos com os polímeros condutores. Um volume final de 1,0mL de solução pré-gel (solução de síntese antes da gelificação) era injetado em um tubo plástico. Após gelificação, o hidrogel era cortado em pedaços cilíndricos de $0,7 \mathrm{~cm}$, afim de que seu volume final fosse de $50 \mu \mathrm{L}$ logo após 
a síntese. Após a preparação, os pedaços eram transferidos para 1,0L de água para remoção de espécies que não reagiram durante $12 \mathrm{~h}$.

3.3.8 - Preparação dos eletrodos encapsulados com hidrogel de PAAM e síntese do compósito hidrogel/polímero condutor

Os eletrodos para a síntese eletroquímica dos compósitos eram preparados simplesmente inserindo aproximadamente $0,4 \mathrm{~cm}$ de um fio de $\mathrm{Pt}$ no centro de um hidrogel de $50 \mu \mathrm{L}$. O eletrodo modificado foi utilizado como eletrodo trabalho na síntese de redes condutoras semi-interpenetrantes. Em célula eletroquímica convencional (já descrita), contendo solução solução $0,5 \mathrm{molL}^{-1}$ de anilina e $1,0 \mathrm{molL}^{-1} \mathrm{HCl}$ em água, foi crescido o polímero condutor potenciostaticamente $(0,75 \mathrm{~V})$ até atingir uma carga préestabelecida.

\subsection{9 - Caracterização do compósito hidrogel/polímero condutor}

\subsubsection{1 - Microscopia Raman e de Força Atômica}

A superfície gerada por um corte transversal do compósito foi a amostra utilizada na microscopia Raman, com radiação excitante em 633nm (laser de He-Ne, com potencia de $\sim 0,35 \mathrm{~mW}$ na amostra). Também foi sintetizada polianilina nas mesmas condições utilizadas para a síntese do compósito porém sem presença do hidrogel para servir como amostra de polianilina livre para a microscopia Raman Com o mesmo compósito foram realizadas imagens de AFM e LFM da sua superfície (inalterada, como obtida na síntese, porém seca durante 12 horas). Na microscopia de força atômica foram utilizados os modos de contato e contato intermitente; a microscopia de força lateral (LFM), que fornece informações sobre o coeficiente de atrito da superfície foi utilizada no modo "interleave", onde diferenças topográficas da superfície são descontadas. Para efeito de comparação também foram obtidas imagens e espectros do hidrogel puro. 


\subsubsection{2 - Microscopia eletrônica de varredura}

Imagens da superfície e de cortes longitudinais e transversais dos hidrogéis e dos compósitos foram obtidas nos modos normal (alto vácuo) e baixo vácuo do microscópio. As amostras foram preparadas primeiro congelando-as em nitrogênio líquido, e em seguida utilizando o próprio vácuo do microscópio para secá-las (liofilização). Depois de secas, as amostras que seriam analisadas no modo de alto vácuo eram recobertas com um filme fino de ouro $(16 \mathrm{~nm})$ pela passagem $40 \mathrm{~mA}$ de corrente durante $60 \mathrm{~s}$ em vácuo no "sputtering" e fixadas no porta-amostra com o auxílio de uma fita adesiva de carbono (a qual também garante o contato elétrico do filme de ouro com o portaamostra), estando prontas para análise. Parâmetros do microscópio como distância de trabalho ("work distance"), tamanho do feixe ("spot size"), pressão e voltagem de aceleração foram ajustadas para cada amostra e posição a fim de se conseguir a melhor imagem.

\subsubsection{3 - Microscopia óptica "in situ"}

Para a realização das imagens da alteração de tamanho do compósito frente à mudança eletroquímica "in situ" do seu estado de oxidação (propriedade de músculo artificial da rede condutora semi-interpenetrante) utilizou-se uma célula eletroquímica cilíndrica de $2 \mathrm{~mm}$ de altura e $3 \mathrm{~cm}$ de diâmetro foi posicionada sob a objetiva (aumento de $100 \mathrm{X}$ ) do microscópio. No centro da célula foi colocado um compósito sintetizado pela eletropolimerização de anilina no interior de um hidrogel 2 até a passagem de 8,5C de carga anódica. O compósito com o fio de Pt ainda inserido em seu interior é o eletrodo de trabalho desta célula e lateralmente uma placa de platina e um eletrodo de calomelano são posicionados, respectivamente como eletrodos auxiliar e de referência. Imagens do compósito oxidado $(0,5 \mathrm{~V})$, reduzido $(-0,5)$ e durante a transição entre os dois estados foram obtidas através do programa de aquisição de imagens InfraView que capturava as imagens da câmera CCD. 
3.3.10 - Liberação de pirocatecol violeta, safranina e tetraciclina a partir do compósito hidrogel/polímero condutor

Depois da síntese eletroquímica, o compósito foi colocado em água destilada e deionizada, durante $12 \mathrm{~h}$, seco e transferido em seguida para uma solução aquosa 5,0 $\mathrm{mmolL}^{-1}$ de pirocatecol violeta, de safranina ou de tetraciclina. A droga-modelo desta forma incorporada foi liberada, em solução aquosa de $\mathrm{HCl}$. A liberação ocorreu em potenciais catódicos e anódicos para se verificar o possível controle eletroquímico na saída da molécula, e foi acompanhada por espectrofotometria UV-Vis. A tabela 6 traz detalhes destes experimentos

Tabela 6 - Condições experimentais dos testes de liberação a partir de compósitos de polianilina/poliacrilamida.

\begin{tabular}{cccc}
\hline Molécula & Solução de liberação & $\begin{array}{c}\text { Volume da solução } \\
\text { de liberação/mL }\end{array}$ & $\lambda_{\text {MÁx }} / \mathrm{nm}$ \\
\hline Safranina & HCl 1,0,0,1 e 0,001 & 50 & 519 \\
mol.L & & \\
Pirocatecol & $\mathrm{HCl} 0,1$ mol.L $\mathrm{L}^{-1}$ & 50 & 441 \\
Tetraciclina & $\mathrm{HCl} 0,1$ e 0,5 mol.L ${ }^{-1}$ & 20 & 356 \\
\hline
\end{tabular}

Também foi utilizada outra forma de carregamento para a tetraciclina, que consistia em passar diretamente o compósito para a solução contendo a droga depois das $12 \mathrm{~h}$ em água, sem secá-lo previamente. Para se determinar a quantidade de tetraciclina incorporada, utilizou-se a espectofotometria em 356nm: preparou-se uma solução (para cada experimento) de $0,5 \mathrm{~mol} . \mathrm{L}^{-1}$ de tetraciclina, tomou-se $5 \mathrm{~mL}$ como padrão e mais $5 \mathrm{~mL}$ para o processo de carregamento. Após o carregamento, as duas soluções eram diluídas $(100 \mu \mathrm{L}$ da solução $+2 \mathrm{~mL}$ de água) e delas se obtinham espectros. A partir da absorção de cada espectro se calculou o número de mols incorporado.

\subsubsection{1 - Microbalança Eletroquímica a cristal de Quartzo (MECQ)}

Experimentos de variação de freqüência (e, portanto de massa) do sistema polimérico constituído de polianilina e polianilina recoberta com Náfion foram realizados utilizando um freqüencímetro da SRS modelo SR620 acoplado a um circuito oscilador, este por sua vez é unido a uma célula eletroquímica onde o eletrodo de trabalho foi um cristal de quartzo (corte $\mathrm{AT}-6 \mathrm{MHz}$ ) de $16 \mathrm{~mm}$ de diâmetro com uma 
das faces recoberta com um filme de ouro (área de $0,2 \mathrm{~cm}^{2}$ ) em contato com o eletrólito. Tanto o potenciostato ( $\mathrm{PG} 3901 \mathrm{da}$ Omnimetra Instrumentos) quanto o freqüencímetro são ligados a um computador.

Os filmes de polianilina foram depositados por voltametria cíclica (de $-0,2$ a $0,8 \mathrm{~V}$, durante 20 ciclos, $\mathrm{v}=50 \mathrm{mV} \cdot \mathrm{s}^{-1}$ ) em uma solução contendo $0,5 \mathrm{~mol} . \mathrm{L}^{-1}$ de anilina e 1,0 mol. $\mathrm{L}^{-1}$ de $\mathrm{HCl}$. Após a síntese, a célula foi desmontada e o filme foi lavado com água destilada. O recobrimento do filme de polianilina foi feito por "casting" de $10 \mu \mathrm{L}$ de solução de Náfion. As medidas de variação de freqüência com o filme de polianilina ou com o filme de polianilina/Náfion foram realizadas em solução de $\mathrm{HCl} 1,0$ mol.L $\mathrm{L}^{-1}$. 


\section{4 - Resultados e discussões}

4.1 - Classificação dos sistemas de liberação controlada de drogas baseados em polímeros condutores

A introdução desta tese trouxe um panorama sobre o estudo de polímeros condutores aplicados a sistemas de liberação controlada de drogas, e frente ao conteúdo apresentado neste trabalho de doutorado, a fim de se facilitar a leitura e criar uma sistematização mais clara de início, propõe-se uma classificação deste tipo de sistema: i. Geração I - sistemas que tem por princípio básico (pressuposto) de atuação a interação eletrostática entre a droga e o polímero condutor ou entre a droga e o sistema polimérico adotado (polímero condutor + polímero convencional). ii. Geração II - sistemas poliméricos (compósitos) cujos ao menos o polímero condutor é, por algum mecanismo induzido eletroquimicamente, responsável pelo controle da liberação de drogas. A definição da Geração II, propositalmente, é muito mais vaga e ampla do que a da Geração I, e por esta mesma razão, provém os estudos e resultados mais interessantes e promissores nesta área de aplicação dos polímeros condutores e é o ponto forte deste trabalho, que será devidamente discutido em seções posteriores.

\section{2 - Primeiros sistemas estudados: Geração I}

Um aspecto geral dos sistemas da Geração I é que estes se apresentam como sistemas poliméricos formados por um ou mais polímeros (condutores e convencionais) depositados na forma de filmes e/ou camadas sobre substratos condutores como platina ou carbono vítreo. Nas próximas seções serão apresentados os resultados obtidos dos estudos deste tipo de sistemas e cada sistema será designado através da(s) sigla(s) do(s) polímeros(s) seguida pelo nome ou pela sigla da droga modelo testada. 


\subsection{1 - Sistema PANI/AS}

No momento em que se iniciou este trabalho, quase não havia estudos sobre a utilização da polianilina como elemento ativo em dispositivos de liberação controlada. Tal fato poderia ser explicado à luz de uma particularidade deste tipo de polímero condutor: a forte dependência de sua eletroatividade frente ao $\mathrm{pH}$, e mais que isso, praticamente sua inatividade elétrica em pHs superiores a $3^{65}$. Esta seria razão suficiente para a maioria dos pesquisadores da área abnegar tentativas de sistemas-modelos baseados na polianilina ou derivados. Porém, o amplo conhecimento acumulado sobre a polianilina e a possibilidade de se tornarem úteis sistemas que possam se submeter a controles eletroquímicos e/ou à composição do meio (como neste caso, o pH) justificam o estudo destes sistemas-modelos. E mesmo nos casos em que o pH do meio seja proibitivo para a utilização da polianilina, julga-se que para o estudo de sistemas alternativos, utilizando, por exemplo, versões sulfonadas da polianilina (as quais são eletroativas numa faixa de $\mathrm{pH}$ maior ${ }^{66,67}$ ) o conhecimento prévio de sistemas contendo polianilina seja importante. Sob esta óptica, descreve-se nesta e na próxima seção os primeiros sistemas estudados, baseados na polianilina.

Na Figura 10 são mostrados os voltamogramas da síntese de polianilina em duas condições: primeiramente foi realizada a polimerização da PANI em solução etanólica contendo $0,5 \mathrm{molL}^{-1}$ de anilina e $1,0 \mathrm{molL}^{-1}$ de AS. Como se partiu de salicilato de sódio, a solução foi feita dissolvendo-se o salicilato de sódio em solução de $\mathrm{H}_{2} \mathrm{SO}_{4} \mathrm{em}$ etanol, o precipitado formado $\left(\mathrm{Na}_{2} \mathrm{SO}_{4}\right)$ foi retirado filtrando-se a solução. Embora se tenha a vantagem do $\mathrm{AS}$ ser solúvel e não ser eletroativo em etanol, tem-se que o crescimento da polianilina neste meio $(\mathrm{pH} \sim 1)$ praticamente não ocorre, tanto por VC (de $-0,2 \mathrm{~V}$ à $0,8 \mathrm{~V}$ a $50 \mathrm{mVs}^{-1}$ ), como potenciostaticamente (a $\left.1,0 \mathrm{~V}\right)$, gerando muito pouco polímero, com quantidade de salicilato incorporada insuficiente para detecção espectrofotométrica.

Foi verificado que numa mistura de água/etanol (50\% em volume) o AS permanece não-eletroativo, portanto foi explorada a síntese eletroquímica da PANI nesta mistura contendo $1,0 \mathrm{molL}^{-1}$ de ácido salicílico: a Figura 11 mostra o voltamograma do filme sintetizado nesta mistura. O crescimento do polímero é mais rápido, gerando potenciostaticamente $(1,0 \mathrm{~V})$, em poucos segundos um filme escuro (preto), estável e mais eletroativo do que o conseguido anteriormente. 


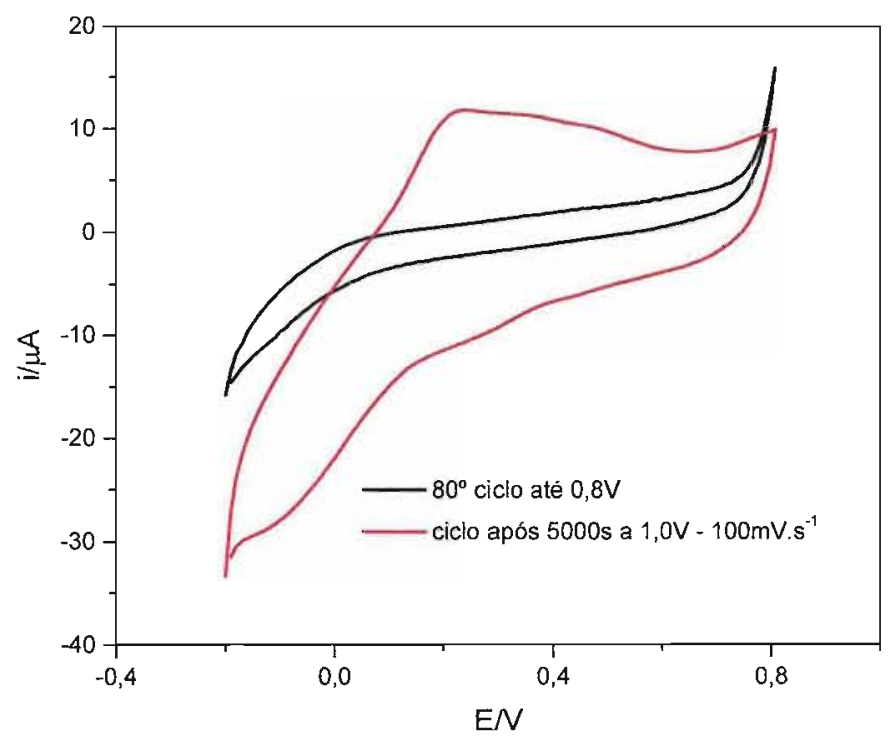

Figura 10 - Síntese da PANI em etanol contendo $1,0 \mathrm{molL}^{-1}$ de AS e $0,5 \mathrm{molL}^{-1}$ de anilina sobre Pt. Preto: após $80^{\circ}$ ciclos, ciclado em $\mathrm{HCl} 0,1 \mathrm{molL}^{-1}$ Vermelho: ciclagem em $\mathrm{HCl} 0,1 \mathrm{molL}^{-1}\left(\mathrm{v}=100 \mathrm{mVs}^{-1}\right)$ após a síntese potenciostática durante $5000 \mathrm{~s}$.

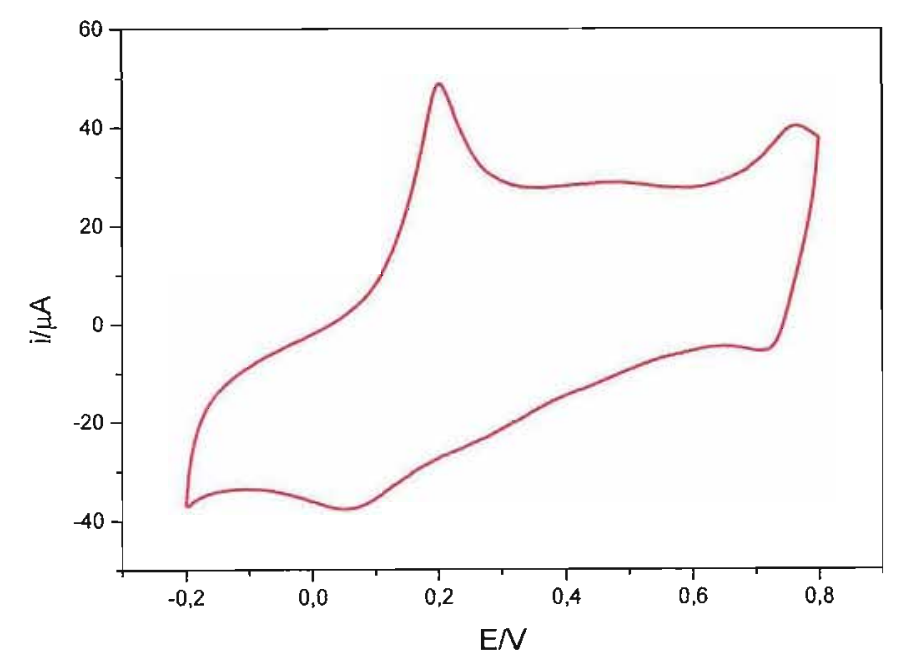

Figura 11 - Voltamograma do filme de PANI sobre $\mathrm{Pt}$ em $\mathrm{HCl} 0,1 \mathrm{molL}^{-1}$ sintetizado potenciostaticamente $(1,0 \mathrm{~V})$ durante $300 \mathrm{~s}$ em solução etanol/água $(50 \%$ em volume) contendo $0,5 \mathrm{molL}^{-1}$ de anilina e $1,0 \mathrm{molL}^{-1}$ de AS. $\mathrm{v}=100 \mathrm{mVs}^{-1}$. 
Aqui cabe ressaltar que o primeiro processo redox da polianilina (leucoesmeraldina $\leftrightarrow$ esmeraldina) ocorre acompanhado pela movimentação predominantemente de ânions (desde que estes sejam pequenos) para se atingir a neutralidade de cargas. Considerando que o estado de oxidação de equilíbrio (a potencial de circuito aberto) da polianilina é o esmeraldina, e que neste estado o polímero está positivamente carregado e necessita de contra-íons na matriz, o mecanismo de liberação do salicilato se dá pela redução do polímero e/ou pela troca iônica com outros ânions presentes na solução de liberação.

Uma vez sintetizada a membrana carregada com o AS, realizou-se a liberação do mesmo em solução aquosa de $\mathrm{HCl} 0,1 \mathrm{molL}^{-1}$, através da redução catódica da PANI a $-0,45 \mathrm{~V}$, porém o espectro UV-Vis registrado desta solução não correspondeu aos espectros do salicilato em água utilizados para construir sua curva analítica. As diferenças espectrais poderiam ter sido causadas por um efeito solvatocrômico, ou seja, a mistura água/etanol alteraria as transições eletrônicas do AS, modificando o espectro em relação àquele obtido em água, mesmo sendo a liberação realizada em água, pois ainda haveria certa quantidade de etanol sendo também liberada do polímero, já que o movimento iônico nos polímeros condutores é acompanhado pela entrada e saída de solvente $^{68}$. Porém, foi confirmado que a presença de etanol no sistema não altera o espectro do AS. Outra possibilidade seria alguma espécie formada durante a polimerização ou durante o processo de liberação estar presente em solução. Uma corroboração para esta hipótese foi obtida espectrofotometricamente, onde se verificou que após a redução catódica de uma solução de AS, em água/etanol sobre eletrodo de Pt recoberto com PANI, está apresenta espectro semelhante ao obtido das soluções de liberação.

Portanto, incorporar o ácido salicílico durante a síntese da polianilina não é um método efetivo para o carregamento da membrana. Outro caminho testado foi o de se eletropolimerizar a anilina sobre $\mathrm{Pt}$, em solução aquosa contendo $0,5 \mathrm{molL}^{-1}$ do monômero e $1,0 \mathrm{molL}^{-1}$ de $\mathrm{H}_{2} \mathrm{SO}_{4}$, por voltametria cíclica (de $-0,2$ à $0,8 \mathrm{~V}$ a $50 \mathrm{mVs}^{-1}$ ). Após a síntese, o polímero era ciclado em ácido sulfúrico $1,0 \mathrm{molL}^{-1}$ (de $-0,2 \mathrm{~V}$ à $0,75 \mathrm{~V}$ a $50 \mathrm{mVs}^{-1}$ ) e nos primeiros ciclos a membrana já estava estabilizada, ou seja, apresentava voltamogramas iguais. Depois do procedimento de estabilização, a membrana era polarizada por $10 \mathrm{~min}$ no potencial do primeiro pico de oxidação (sempre por volta de $0,20-0,25 \mathrm{~V}$ ) na mesma solução para se garantir que o polímero atingisse 
mais rapidamente seu potencial de circuito aberto e que na próxima etapa estivesse na forma mais condutora.

A desdopagem química da membrana, logo após sua polarização, era realizada mergulhando-se o eletrodo em hidróxido de amônio concentrado por $1 \mathrm{~h}$ sob agitação magnética. A dopagem, também química, foi realizada em solução etanólica de AS $1,0 \mathrm{molL}^{-1}$, sob agitação magnética por um período de tempo variado em cada experimento.

Para comprovar a protonação e dopagem da PANI pelo ácido salicílico após o procedimento descrito acima, foi realizada uma série de voltamogramas, um para cada etapa. Assim na Figura 12 pode-se ver os voltamogramas da síntese, estabilização, da membrana logo após a desdopagem, depois de dopada com AS e por fim novamente em ácido sulfúrico. Os voltamogramas da síntese (último voltamograma de crescimento do filme na solução de síntese) e de estabilização são os esperados para a polianilina sintetizada e ciclada num eletrólito inorgânico como o sulfato ${ }^{69}$. Por volta de $0,2 \mathrm{~V}$ temse o pico de oxidação referente à passagem da forma leucoesmeraldina para a esmeraldina e a volta (pico catódico) em aproximadamente $0,0 \mathrm{~V}$ e nesta faixa de potencial (até $0,75 / 0,80 \mathrm{~V}$ ), se verifica somente o inicio do segundo processo redox, não chegando a se ter os picos do par redox.

Os voltamogramas da desdopagem (polímero ciclado depois da desdopagem química) e dopagem em AS (polímero ciclado após dopagem química) foram feitos em $\mathrm{KCl} 0,1 \mathrm{molL}^{-1}$ e embora a eletroatividade da polianilina seja extremamente dependente da acidez do meio ${ }^{65}$ e num pH maior que 3 a PANI já é um polímero praticamente inativo, foi possível verificar a dopagem pelo ácido salicílico pela diferença de corrente observada nos dois voltamogramas, ou seja, mesmo em $\mathrm{KCl}$, a PANI apresenta considerável eletroatividade depois do procedimento de dopagem, quando comparada com o filme da PANI na sua forma básica. Tal comparação seria inviável se esses voltamogramas tivessem sido realizados em meio ácido, pois como se vê na Figura 12, imediatamente $\left(1^{\circ}\right.$ ciclo) haveria a protonação e/ou a troca iônica, impossibilitando a comparação como feita aqui. 


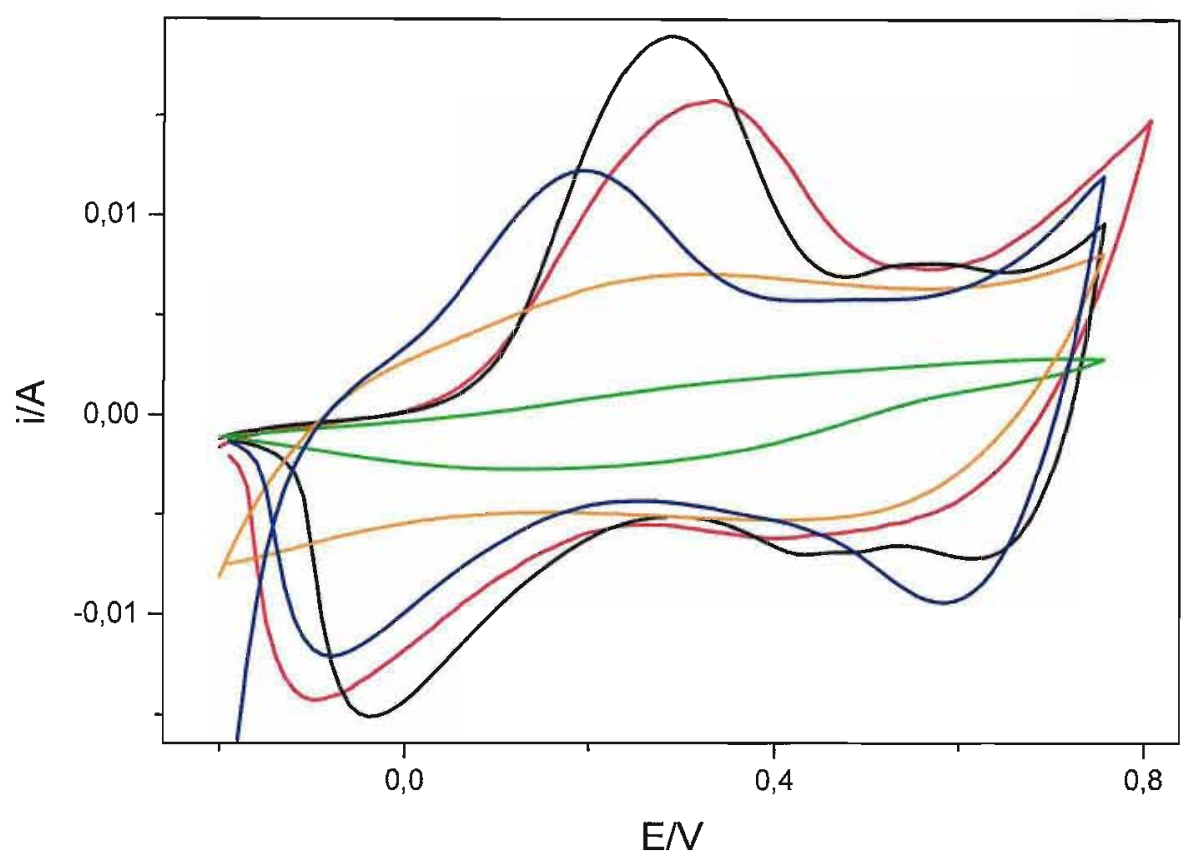

Figura 12 - Voltamogramas de um filme de PANI crescido por VC (40 ciclos de $-0,2$ à $0, .8 \mathrm{~V}, 50 \mathrm{mVs}^{-1}$ ) em solução de $0,5 \mathrm{molL}^{-1}$ de anilina e $1,0 \mathrm{molL}^{-1} \mathrm{de}_{2} \mathrm{SO}_{4}$.

- Último voltamograma da síntese.

- Voltamograma em 1,0molL ${ }^{-1}$ de $\mathrm{H}_{2} \mathrm{SO}_{4}$ logo após a síntese (estabilização).

- Voltamograma em $\mathrm{KCl} 0,1 \mathrm{molL}^{1}$ da forma básica (desdopagem).

- Voltamograma em $\mathrm{KCl} 0,1 \mathrm{molL}^{1}$ do filme dopado com AS (dopagem).

- Voltamograma em $1,0 \mathrm{molL}^{-1} \mathrm{de}_{2} \mathrm{SO}_{4}$ do filme dopado com AS.

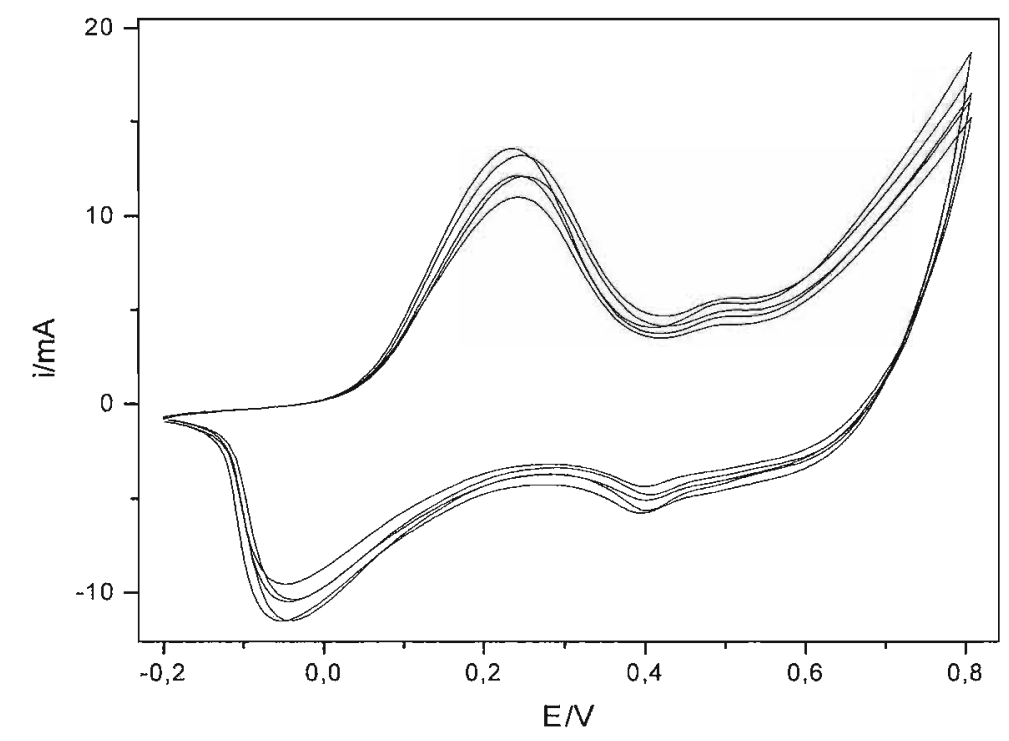

Figura 13 - Voltamogramas de várias sínteses de filme de PANI sobre Pt, correspondentes ao último ciclo da síntese. $\mathrm{v}=50 \mathrm{mVs}^{-1}$. 
Como já discutido na seção experimental, o parâmetro relativo à quantidade de polímero depositada foi o número de ciclos na síntese, e pode-se verificar na Figura 13 que tal escolha foi satisfatória quanto à reprodutibilidade da síntese.

Uma vez caracterizado eletroquimicamente o processo de síntese e carregamento químico da membrana com AS realizou-se os experimentos de liberação controlada, para tal foi definida uma condição de síntese polimérica: crescimento do filme sobre Pt por $\mathrm{VC}\left(-0,2 \mathrm{~V}\right.$ à $0,8 \mathrm{~V}, 50 \mathrm{mVs}^{-1}, 20$ ciclos $)$ em solução de anilina $0,5 \mathrm{molL}^{-1} \mathrm{e}$ ácido sulfúrico $1,0 \mathrm{molL}^{-1}$. Na tabela 7 tem-se um resumo das etapas experimentais, desde a polimerização até a liberação do AS.

Tabela 7 - Resumo dos procedimentos experimentais para o sistema PANI/AS.

\begin{tabular}{|c|c|c|}
\hline$E T A P A$ & SOLUÇÃO & OBSERVAÇÃO \\
\hline síntese & $\begin{array}{l}\text { aquosa de anilina } 0,5 \mathrm{molL}^{-1} \\
\text { e ácido sulfúrico } 1,0 \mathrm{molL}^{-1}\end{array}$ & $\begin{array}{c}\text { VC, } 20 \text { ciclos sobre disco } \\
\text { de } \mathrm{Pt}\end{array}$ \\
\hline estabilização & $\begin{array}{l}\text { aquosa de ácido sulfúrico } \\
\qquad 1,0 \mathrm{moll}^{-1}\end{array}$ & $\begin{array}{c}10 \text { min no } 1^{\circ} \mathrm{E}_{\mathrm{p}} \text { de oxidação } \\
\text { da PANI }\end{array}$ \\
\hline desdopagem & $\mathrm{NH}_{4} \mathrm{OH}$ concentrado & 1h sob agitação magnética \\
\hline dopagem & etanólica de AS $1,0 \mathrm{molL}^{-1}$ & Xh sob agitação magnética \\
\hline $\begin{array}{l}\text { liberação } \\
\text { controlada }\end{array}$ & aquosa de $\mathrm{HCl} 0,1 \mathrm{molL}^{-1}$ & pulsos de $-0,45 \mathrm{~V}$ \\
\hline
\end{tabular}

O primeiro parâmetro escolhido para se estudar neste sistema foi o tempo de dopagem, ou seja, qual o tempo de carregamento da membrana necessário para se alcançar uma quantidade máxima de AS liberada. Para a construção das curvas de liberação (quantidade de fármaco liberada x tempo de liberação) que serão apresentadas, valores de absorbância em 303nm dos espectros da solução de liberação foram transformados em número de mols através da equação da curva analítica "Absorbância $=-0,0108+3571,82^{*}$ concentração", com $\mathrm{R}=0.99987$.

Em cada experimento temos uma seqüência de espectros da mesma solução tomados em diferentes tempos de liberação até não haver mais aumento de absorbância em $303 \mathrm{~nm}$, ou seja, até a total liberação do AS. A Figura 14 é um exemplo destes resultados. Na Figura 15 pode-se ver que variando-se o tempo de dopagem tem-se que a quantidade de droga liberada é diretamente proporcional ao tempo de dopagem, atingindo a saturação em aproximadamente $2 \mathrm{~h}$. 


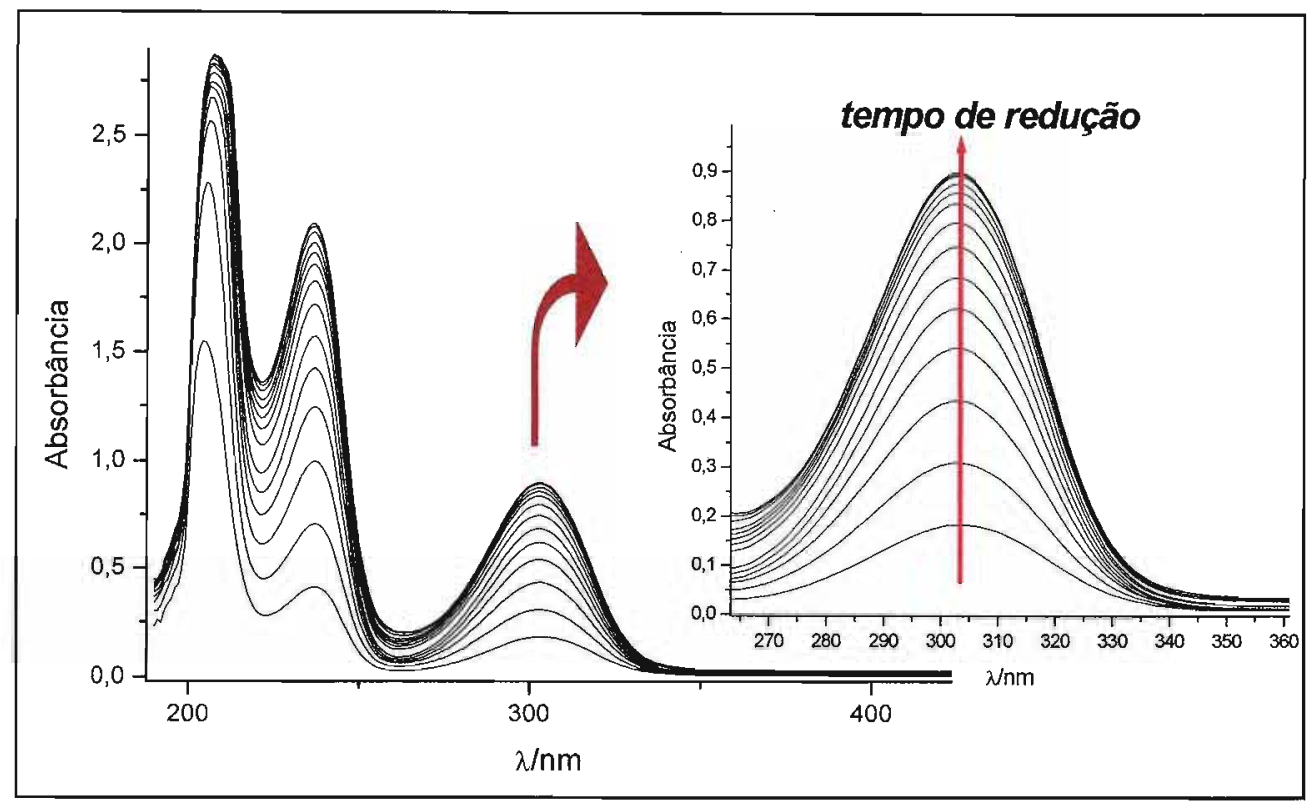

Figura 14 - Espectros de absorbância da solução de liberação de AS. Tempo de dopagem: $1 \mathrm{~h}$.

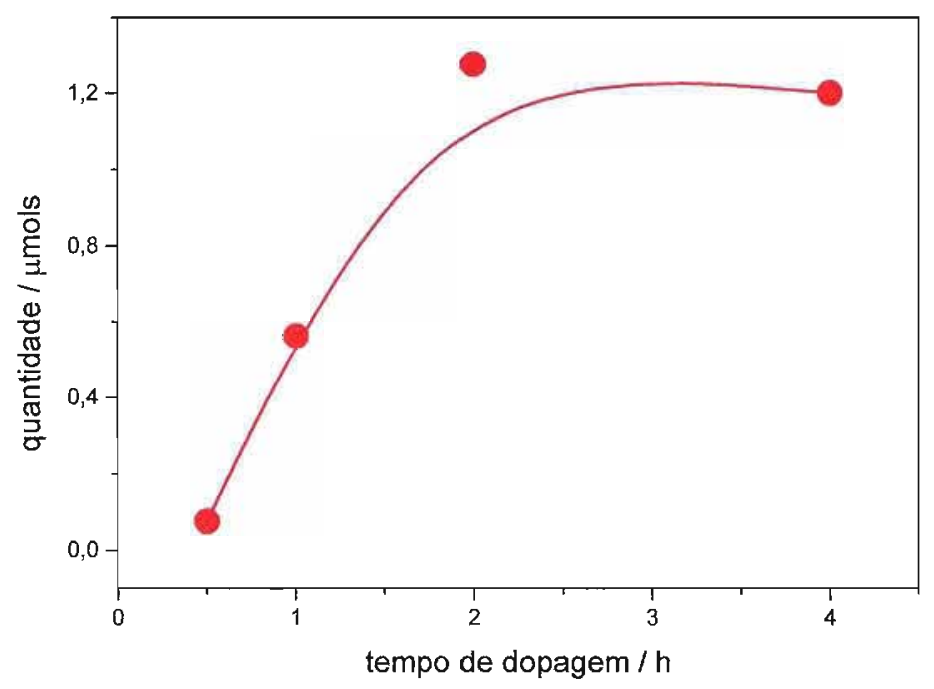

Figura 15 - Quantidade de AS liberada em função do tempo de dopagem do filme de polianilina. 
Confirmar o efeito do potencial aplicado na alteração da velocidade de liberação da droga é o ponto mais importante deste estudo, assim na Figura 16 tem-se a comparação de duas curvas de liberação, uma é a produzida pela aplicação de $-0,45 \mathrm{~V}$ à membrana e a outra foi gerada pela saída espontânea de AS para a solução. Vê-se claramente que quando a membrana é reduzida, a liberação é mais rápida (aproximadamente 20 vezes considerando $100 \%$ do total liberado). No caso da liberação espontânea, temos a membrana no seu estado oxidado (ECA), então não há razão, do ponto de vista de se atingir a neutralidade das cargas, da saída da droga, porém a troca iônica é um fator importante no controle da velocidade de liberação e a princípio pode ser controlada alterando-se a composição e a força iônica da solução de liberação. E, quando há a aplicação do potencial catódico na membrana, além da troca iônica, tem-se a necessidade do fluxo do AS para fora do polímero, uma vez que no polímero reduzido não há cargas positivas nem a necessidade da presença de contra-íons, portanto a soma dos dois fatores acelera a saída da droga da membrana.

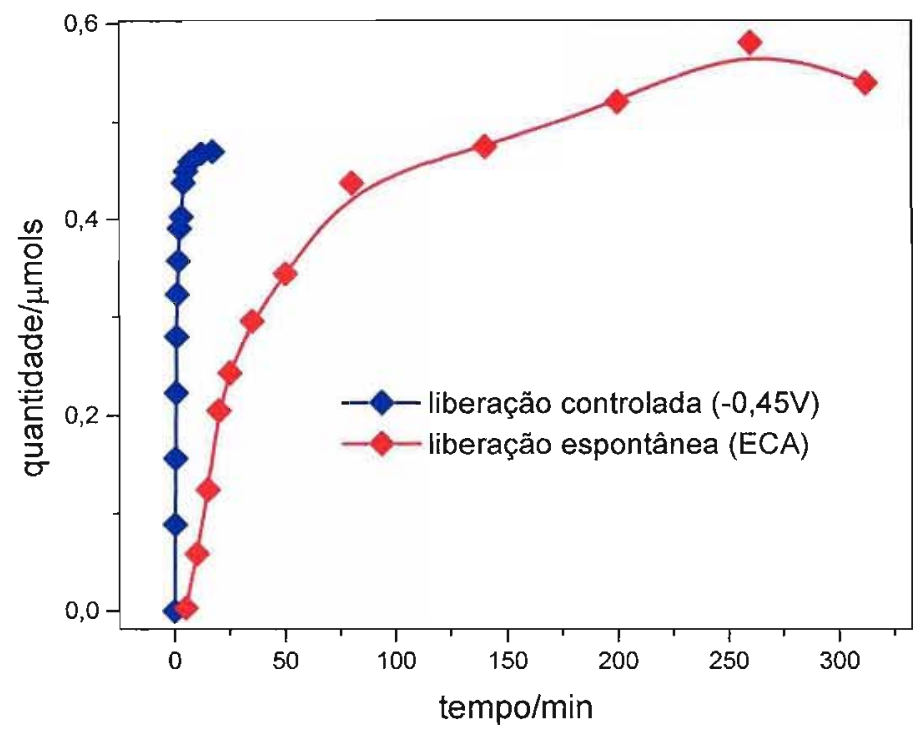

Figura 16 - Curvas de liberação de AS em $\mathrm{HCl} 0,1 \mathrm{molL}^{-1}$. Cada curva foi produzida com dados gerados a partir de duas membranas diferentes dopadas por $1 \mathrm{~h}$.

A comparação do tempo de saída para a liberação espontânea e controlada só pode ser feita porque o tempo de carregamento das membranas foi o mesmo e conseqüentemente a quantidade de droga incorporada foi a mesma (dentro da mesma ordem de grandeza). Através da Figura 17 verificou-se que diferentes tempos de 
dopagem resultaram em diferentes tempos de liberação (considerando $100 \%$ do total liberado) controlada a $-0,45 \mathrm{~V}$.

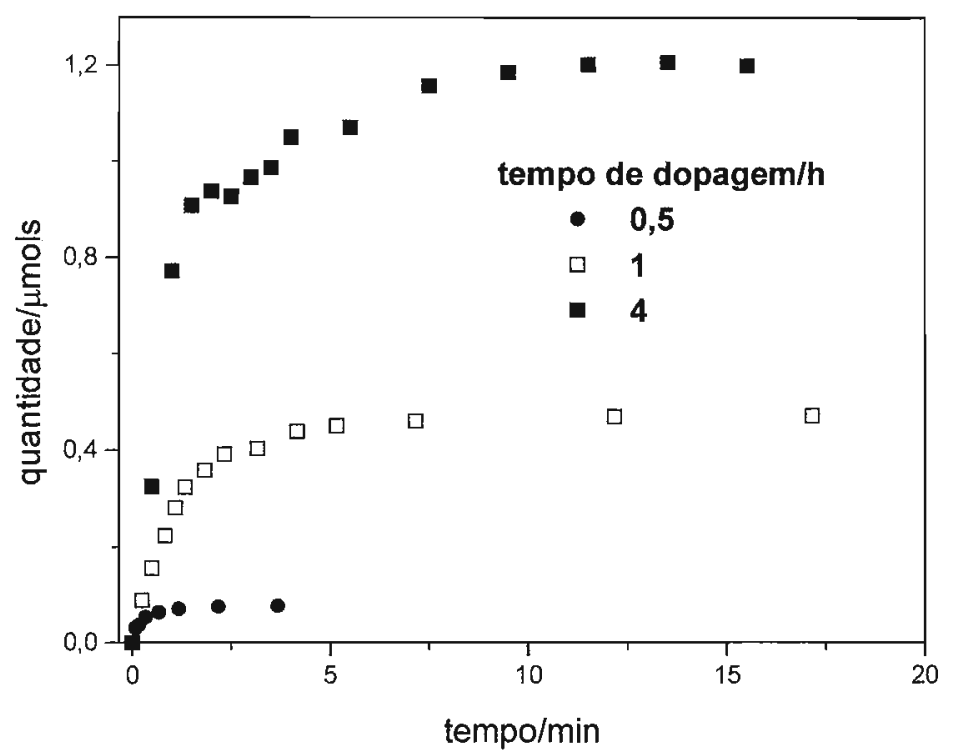

Figura 17 - Comparação entre curvas de liberação obtidas para tempos de dopagem diferentes.

O próximo parâmetro a ser estudado seria o potencial de liberação, pois esta é a forma mais direta de se controlar a velocidade de liberação, por exemplo, para este sistema espera-se que quanto mais negativo o potencial, maior a velocidade, como visto em outros sistemas utilizando polímeros condutores ${ }^{24,28}$. Porém, desde o estudo do parâmetro anterior, viu-se que o sistema não tinha uma boa reprodutibilidade. É importante descartar que esse comportamento não-reprodutível não foi causado pelo potencial catódico $(-0,45 \mathrm{~V})$, já que nos resultados apresentados, o total de AS liberado foi alcançado espontaneamente em alguns experimentos e com a aplicação de potencial em outros. Como o sistema é capaz de controlar a liberação de ácido salicílico com o potencial aplicado, julga-se esta uma metodologia simples que pode ser aproveitada no desenvolvimento de dispositivos comerciais, porém como não conseguiu-se identificar com exatidão a origem da irreprodutibilidade deste sistema, optou-se por estudos mais detalhados de outro sistema baseado em filmes de polianilina como será mostrado na seção seguinte. 


\subsection{2 - Sistema PANI/Náfion/DOPA}

A polianilina sintetizada convencionalmente com ácidos inorgânicos como o ácido sulfúrico ou clorídrico, é, como já mencionado anteriormente, um polímero condutor que compensa carga em sua matriz através, predominantemente, da movimentação de ânions. Assim, se o objetivo for o estudo de um sistema eficaz no controle eletroquímico da incorporação e liberação de drogas-modelo que sejam catiônicas, é necessário dispor de alguma estratégia para “inverter" o fluxo iônico na matriz polimérica, tornando-o, o mais catiônico possível. Na introdução desta tese são citados estudos que alcançam tal efeito pela síntese de polímeros condutores contendo dopantes poliméricos. Neste trabalho optou-se por recobrir filmes de polianilina dopados com íons cloreto ou sulfato com uma camada de Náfion, um polímero fluorado conhecidamente utilizado como membrana capaz de diminuir ou até mesmo impedir o fluxo aniônico ${ }^{70}$, a fim de se obter um sistema com a propriedade de controlar eletroquimicamente a liberação de dopamina na sua forma protonada, um cátion.

Este sistema polimérico de duas camadas foi eficaz no carregamento e liberação da dopamina. A quantidade de dopamina liberada em função do tempo (com aplicação de potencial ou a ECA) foi acompanhada por espectrofotometria UV-Vis, já que a dopamina protonada possui uma absorção característica no ultra-violeta (máximo em 280nm). A Figura 18 mostra a banda de absorção com o máximo usado na construção da curva analítica da dopamina.
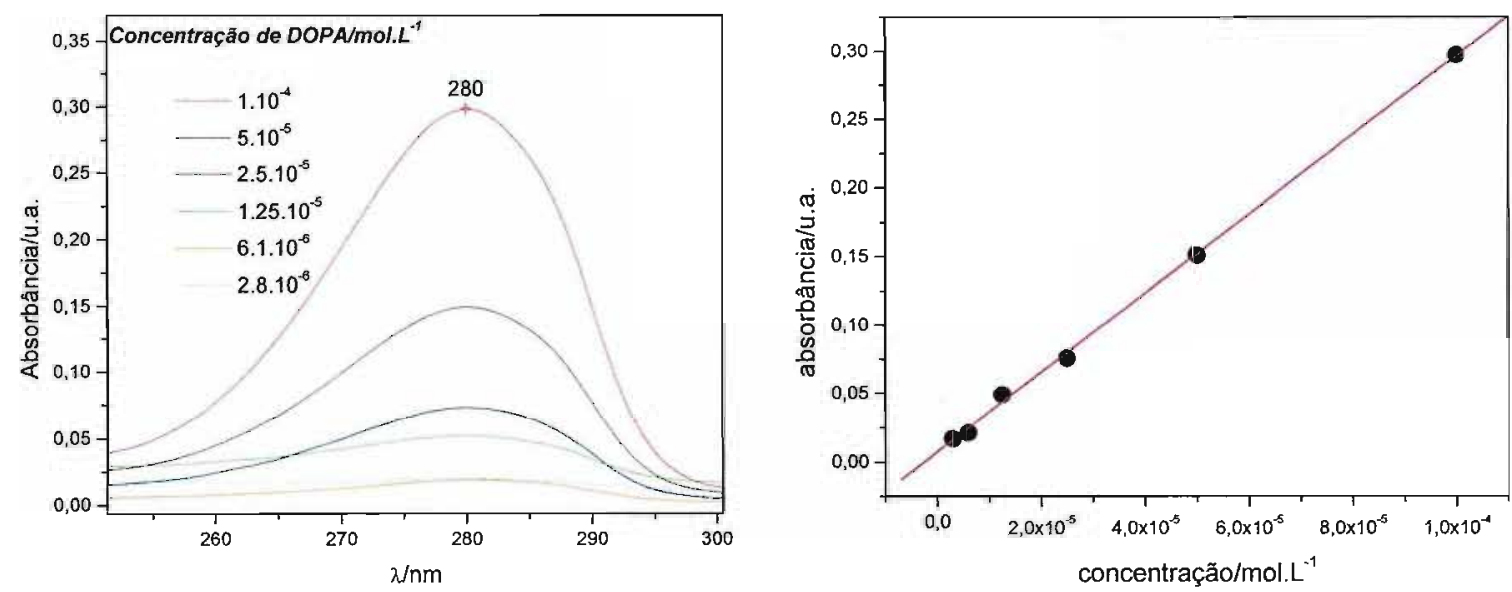

Figura 18 - Espectros UV-Vis de soluções aquosas dopamina protonada em diferentes concentrações e curva analítica construída com valores de absorbância no máximo, em $280 \mathrm{~nm}$. Equação da reta: Absorbância $=0,007+2891,66^{*}$ concentração, com $\mathrm{R}=0,9995$. 
Na Figura 19 tem-se o voltamograma da primeira membrana preparada pela eletropolimerização de anilina em disco de Pt por VC entre $-0,2$ e 0,8V, 20 ciclos a $50 \mathrm{mVs}^{-1}$ em solução de $0,5 \mathrm{molL}^{-1}$ do monômero e $1,0 \mathrm{molL}^{-1}$ de $\mathrm{HCl}$. Após a eletrosíntese, o filme foi recoberto com $4 \mu \mathrm{L}$ de solução de Náfion e seco ao ar. A voltametria cíclica da polianilina recoberta com Náfion, também mostrada na Figura 19, não mostrou nenhuma alteração na eletroatividade do polímero condutor.

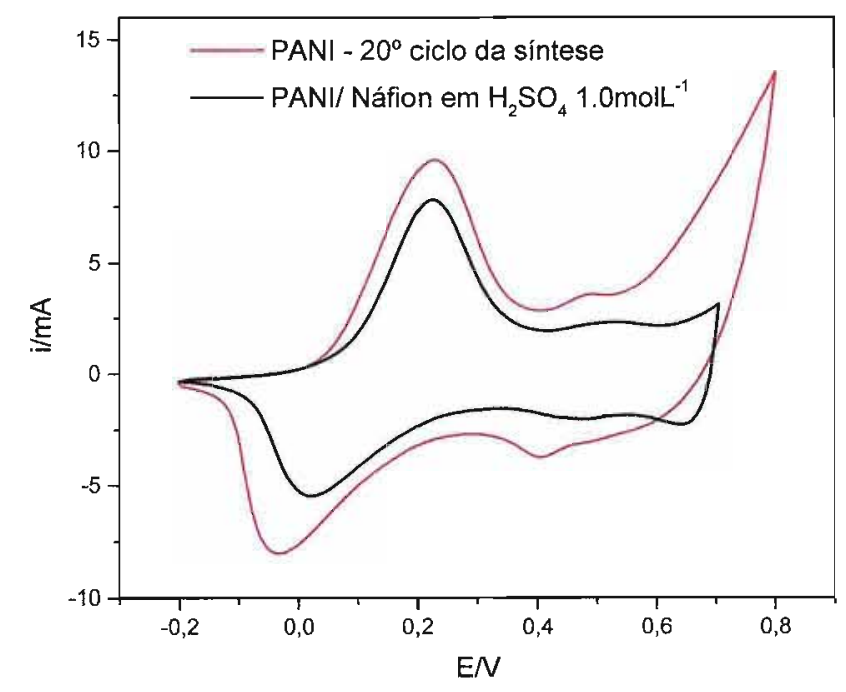

Figura 19 - Voltametria cíclica da PANI. Vermelho: crescimento do filme (detalhes no texto) Azul: mesmo filme após a síntese, recoberto com Náfion e ciclado em $\mathrm{H}_{2} \mathrm{SO}_{4}$ $1,0 \mathrm{moll}^{-1}$ a $50 \mathrm{mVs}^{-1}$. Notar que não há alteração da resposta eletroquímica devido à presença da camada de Náfion sobre a polianilina.

Após a preparação, o filme foi oxidado a $0,4 \mathrm{~V}$ em $\mathrm{HCl} 0,1 \mathrm{molL}^{-1}$ por $30 \mathrm{~min}$ para remoção de cátions em excesso e depois foi reduzido a $-0,3 \mathrm{~V}$ em solução aquosa de DOPA $0,1 \mathrm{molL}^{-1}$ também durante $30 \mathrm{~min}$. A liberação foi realizada em $\mathrm{HCl}$ $0,1 \mathrm{molL}^{-1} \mathrm{com}$ a membrana polarizada a $0,18 \mathrm{~V}$. Na figura 20 tem-se os espectros desta solução e a curva de liberação, que mostram a presença de dopamina, e que $\sim 0,2 \mu \mathrm{mol}$ (no total) desta foi liberada em 10 minutos de aplicação do potencial. Para se confirmar o comportamento do sistema e avaliar sua reprodutibilidade, o primeiro experimento foi repetido. Comparando-se as duas curvas de liberação obtidas, pode-se dizer que o sistema conseguiu reproduzir a forma da saída de DOPA do sistema, alcançando praticamente o mesmo total liberado $\left(\sim 3,5 \mu \mathrm{mol} . \mathrm{cm}^{-2}\right)$ em $10 \mathrm{~min}$. Contudo, experimentos posteriores mostraram que o sistema era na verdade pouco reprodutível. 


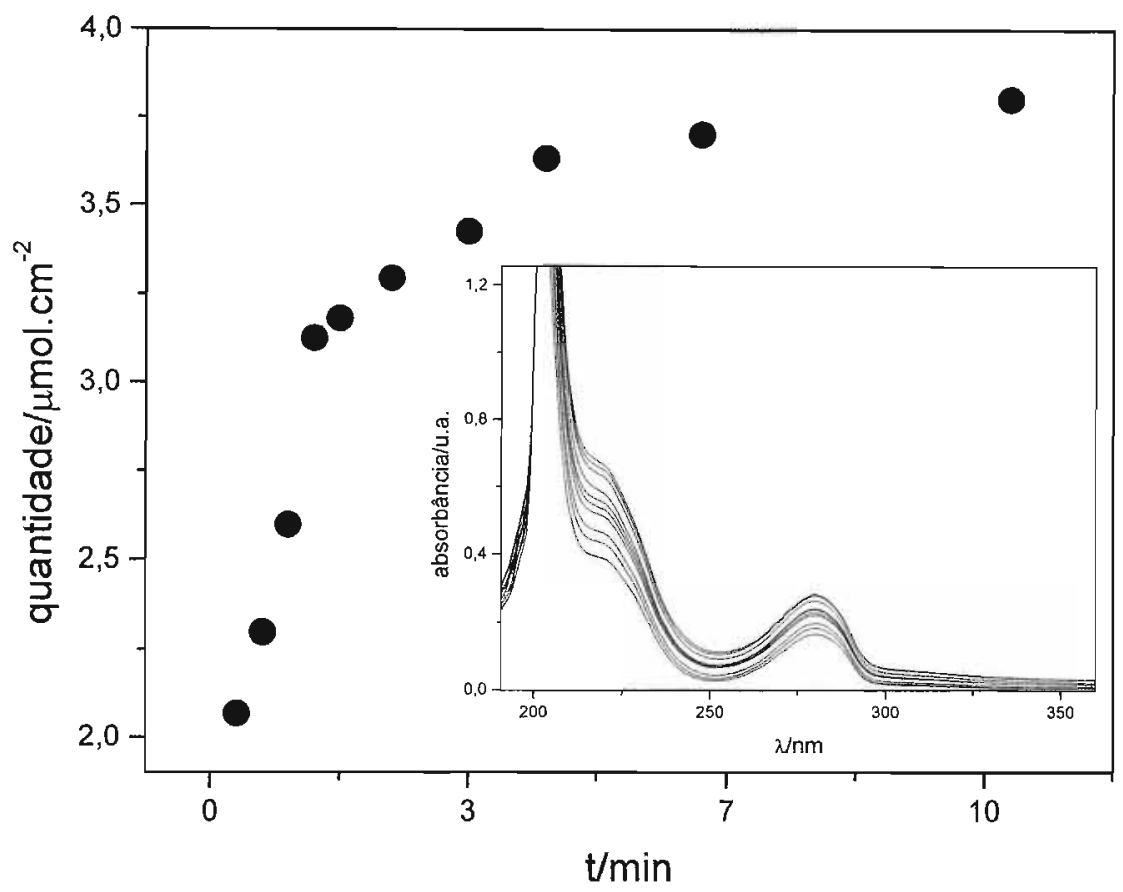

Figura 20 - Primeiro experimento de liberação controlada para o sistema PANI/Náfion/DOPA. Curva de liberação (gráfico principal) construída a partir dos espectros da solução de liberação obtidos em diferentes tempos (inserto).

Várias tentativas foram realizadas com o intuito de melhorar o sistema $\mathrm{e}$ somente quando se eliminou o $\mathrm{O}_{2}$ de todo o procedimento experimental, conseguiu-se estabelecer uma condição em que os experimentos de liberação foram reprodutíveis. Definiu-se então o procedimento mostrado na tabela 8 de preparação dos filmes e liberação.

Tabela 8 - Procedimento experimental para o sistema PANI/Náfion/DOPA

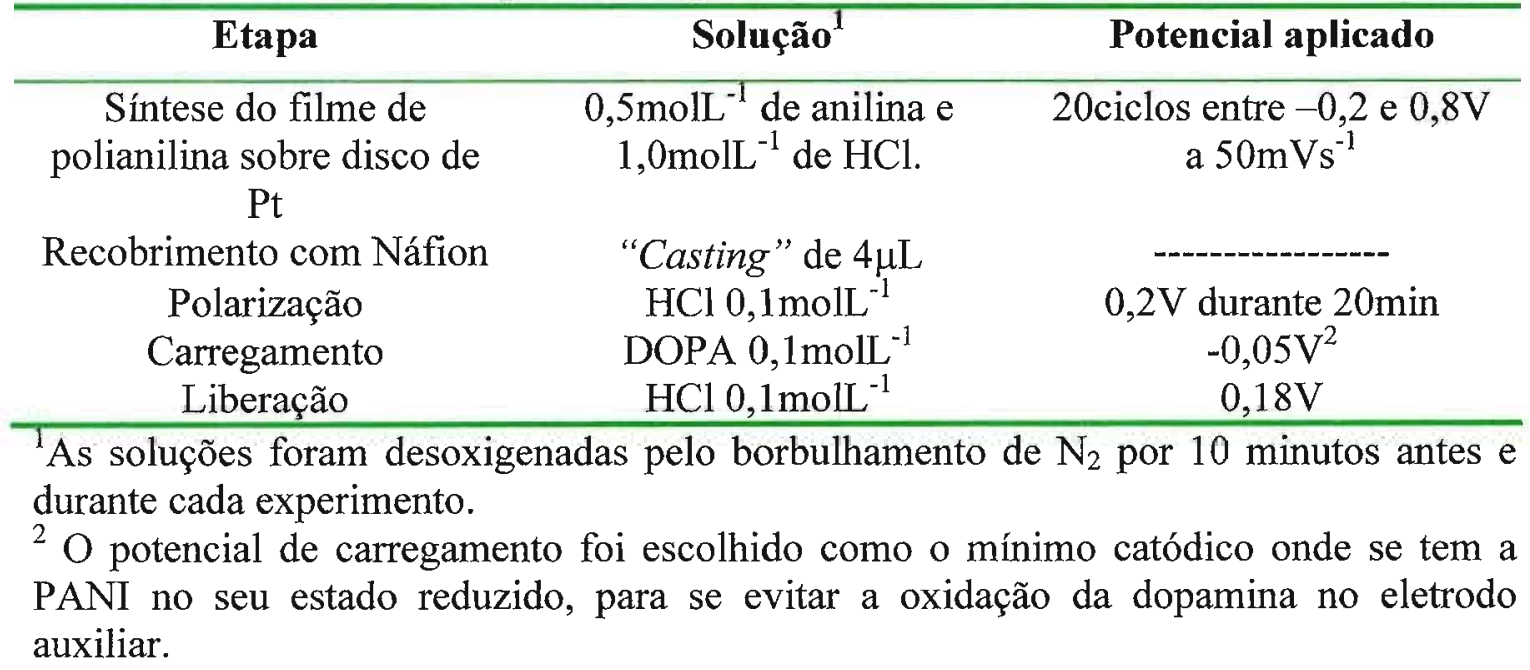


A influência do tempo de carregamento na quantidade de DOPA liberada foi o primeiro parâmetro estudado, pois os resultados poderiam diminuir a duração de cada experimento, o que otimizaria o estudo dos demais parâmetros. Como pode ser visto na Figura 21, o tempo de carregamento da membrana foi estudado entre 5 e $120 \mathrm{~min}$, e verificou-se que em 5 min já se alcança um máximo de DOPA liberada $\left(4,5 \mu \mathrm{molcm}^{-2}\right)$, já que nos demais experimentos, a quantidade variou de 3 a $6 \mu \mathrm{mol} . \mathrm{cm}^{-2}$, mas não de forma crescente com o tempo

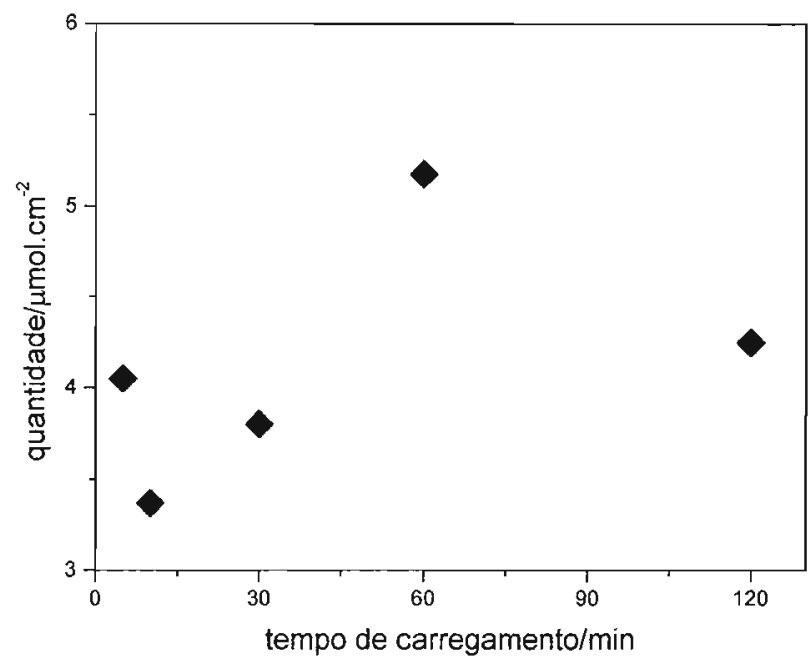

Figura 21 - Quantidade de dopamina liberada do sistema PANI/Náfion em função do tempo de carregamento da membrana.

O resultado apresentado na Figura 21 foi obtido a partir das curvas de liberação mostradas na Figura 22. Cada ponto da curva de quantidade $\mathrm{x}$ tempo de carregamento foi a média de no mínimo dois resultados e no conjunto das curvas de liberação verificase a reprodutibilidade na forma e na quantidade total liberada.

A Figura 23 mostra a voltametria cíclica da PANI na presença de DOPA e pode-se verificar que a oxidação desta só começa em $\mathrm{E}>0,5 \mathrm{~V}$, portanto foi possível estudar o efeito de potenciais mais anódicos que $0,18 \mathrm{~V}$ na liberação da droga. A Figura 24 mostra uma curva de liberação que evidencia tal efeito. Este experimento mostrou que além da velocidade, o potencial pode também controlar a quantidade de dopamina liberada, pois no pulso mais longo $(0,18 \mathrm{~V})$ tem-se uma curva de liberação como visto até então, com a quantidade de dopamina liberada atingindo um patamar, ponto em que se considerava o fim da liberação, porém a aplicação de pulsos maiores resultou na 
liberação de mais $\sim 0,47 \mu$ molcm $^{-2}$ de DOPA ( $16 \%$ do total liberado antes da aplicação do segundo pulso - Figura 24).
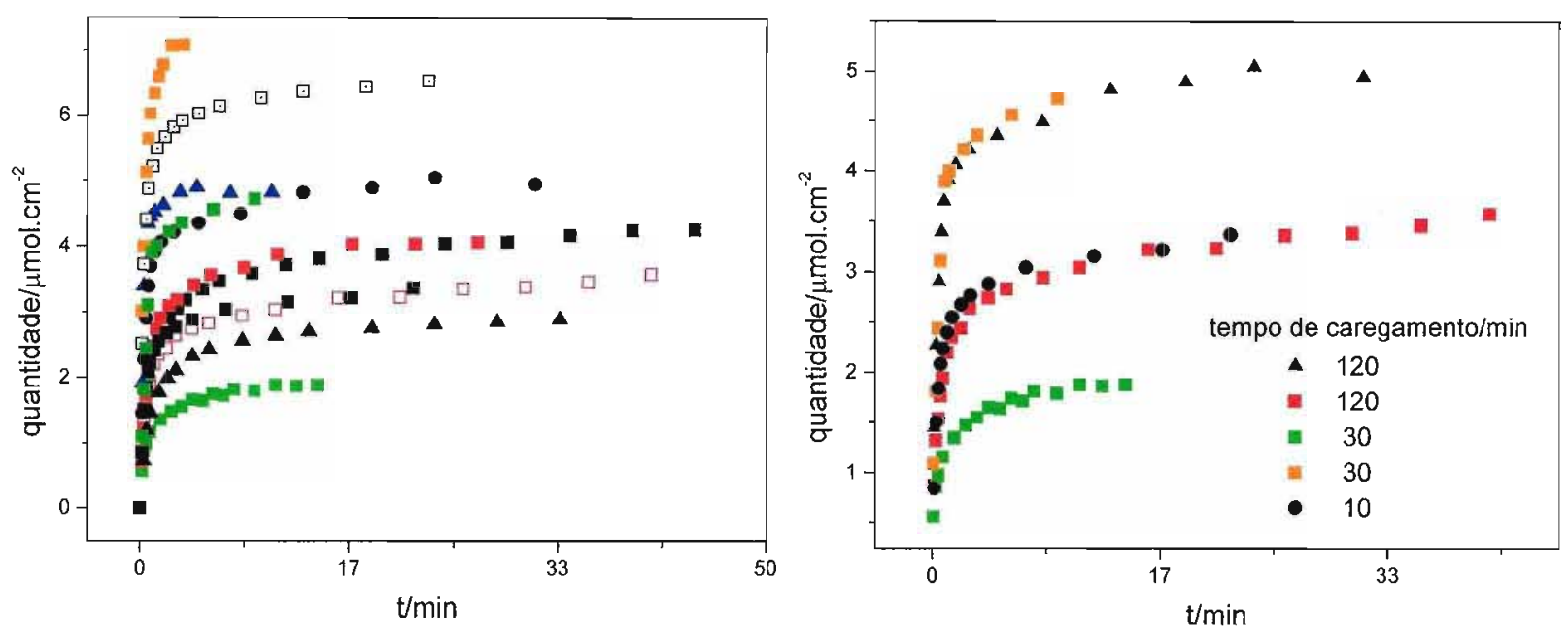

Figura 22 - Curvas de liberação de DOPA em $\mathrm{HCl} 0,1$ moll $^{-1}$ a $0,18 \mathrm{~V}$. Esquerda: todas as curvas resultantes de diferentes tempos de carregamento. Direita: algumas curvas selecionadas, mostrando que a quantidade liberada independe do tempo de carregamento.

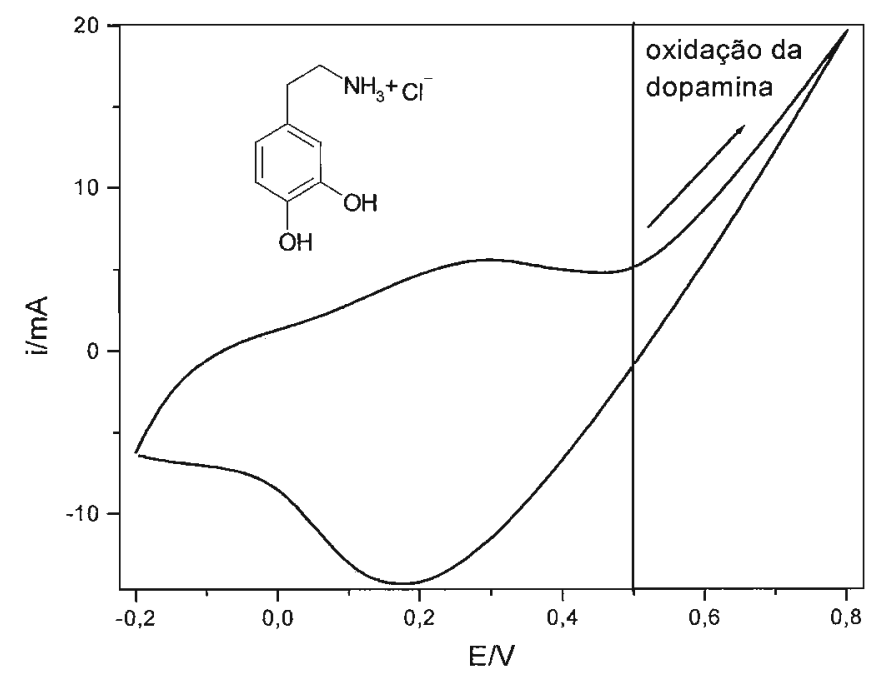

Figura 23 - Voltamograma de um filme de polianilina em solução aquosa de DOPA $0,1 \mathrm{molL}^{-1}$ e $\mathrm{HCl} 0,1 \mathrm{molL}^{-1}$. No detalhe, a estrutura da dopamina protonada (sal de cloreto). 


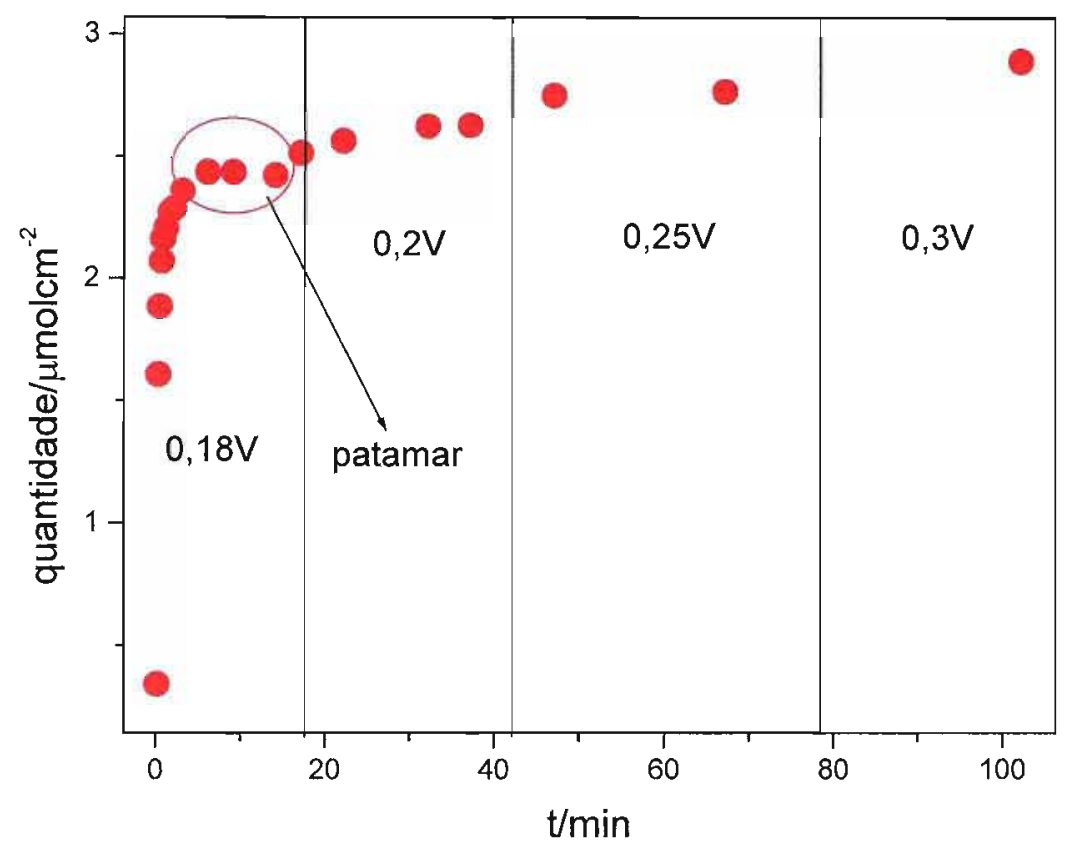

Figura 24 - Efeito do potencial aplicado na de liberação controlada de dopamina em $\mathrm{HCl} 0,1 \mathrm{molL}^{-1}$.

Foi verificado que a incorporação da DOPA no sistema só ocorre quando o polímero condutor está no seu estado reduzido, independente da polianilina estar ou não recoberta com Náfion. A liberação, por sua vez, ocorre em qualquer potencial aplicado à membrana, seja em meio com força iônica $=0$, ou na presença de eletrólito como é mostrado na Figura 26 a qual será discutida a seguir.

Na Figura 25 verifica-se a impossibilidade de se manter o sistema reduzido (potenciais testados entre $-0,05 \mathrm{e}-0,2 \mathrm{~V}$ ), com a intenção de cessar a saída do fármaco ou diminuir sua velocidade, já que este procedimento além de não conseguir reter a dopamina no sistema, causa o aparecimento de outras espécies na solução. Assim este sistema (com os parâmetros estudados) já não atende a um dos objetivos dos SLDs controlados eletroquimicamente, ou seja não tem a capacidade liga/desliga. Uma razão para a membrana reduzida não conseguir manter a dopamina, mas somente reduzir sua velocidade de liberação é simplesmente a troca iônica, uma vez que a liberação era realizada em uma solução contendo eletrólitos. A Figura 26 mostra que a força iônica da solução é um importante fator no controle da liberação, porém esta ocorre mesmo em meio com força iônica $=0$, pois a própria membrana pode carregar íons, como cloreto, em excesso, fato este também que explica como se pode realizar um experimento eletroquímico (e obter uma resposta eletroquímica) em água deionizada. 

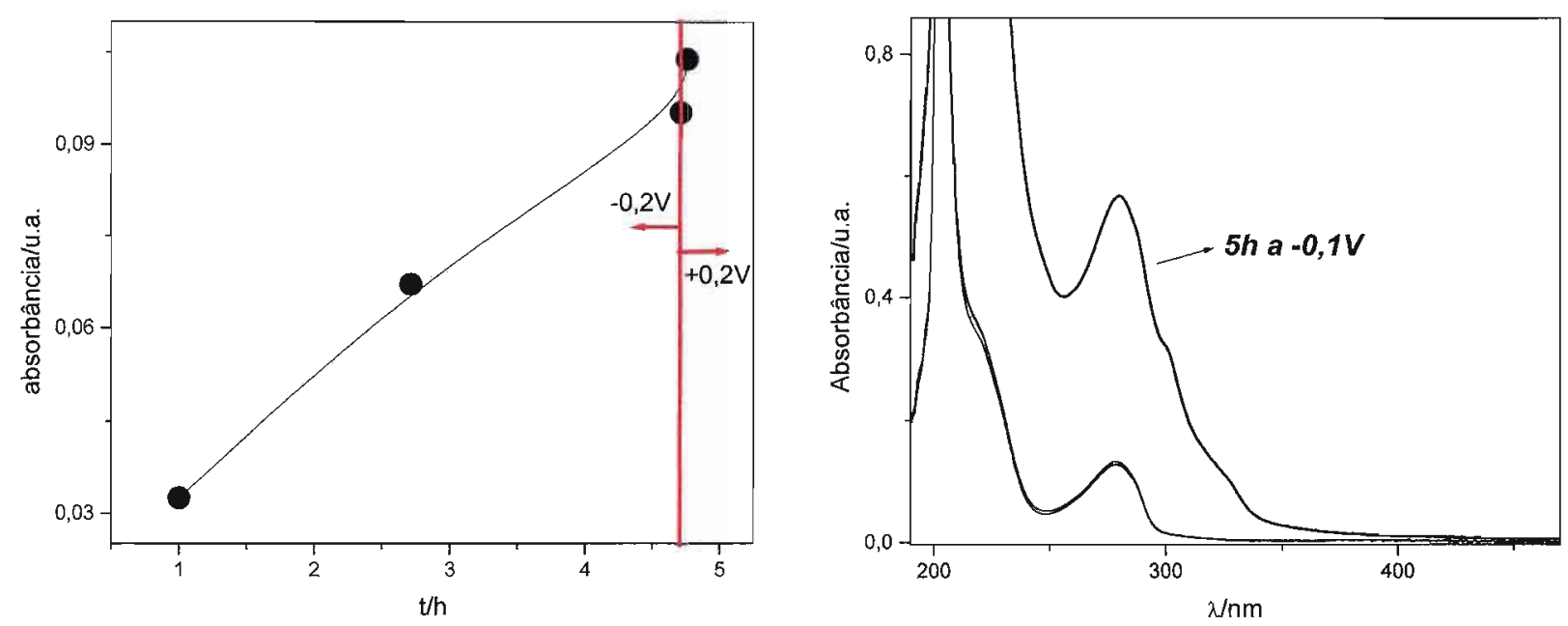

Figura 25 - Esquerda: liberação com a membrana reduzida $(-0,2 \mathrm{~V})$ e depois oxidada $(0,2 \mathrm{~V})$. Direita: espectros da solução aonde foi mantida uma membrana a $-0,1 \mathrm{~V}$ durante 5h. Notar que a aplicação do pulso catódico diminui a velocidade de liberação, como esperado, porém causa mudanças no espectro da DOPA.

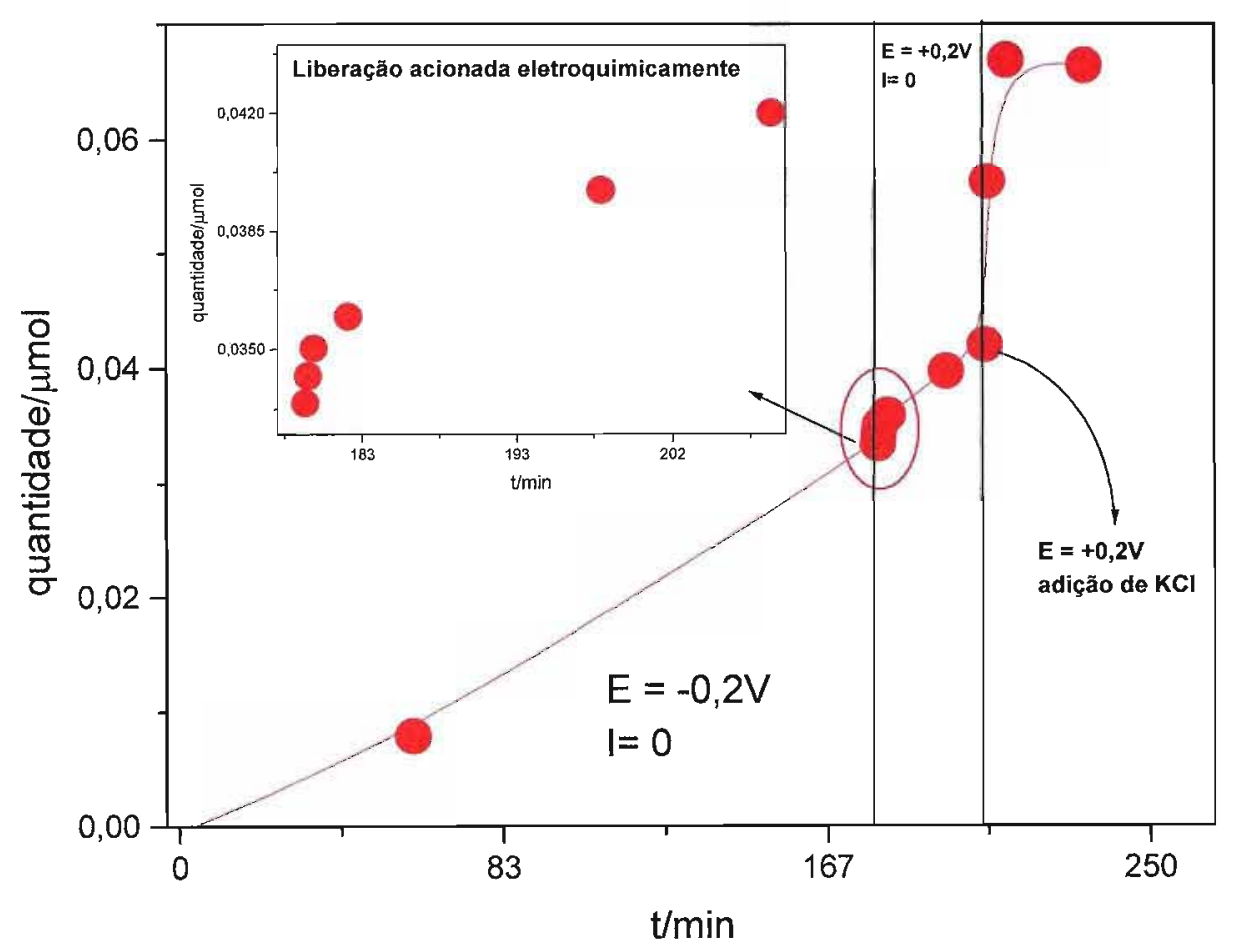

Figura 26 - Liberação da dopamina em diferentes condições: efeito do potencial aplicado e da composição da solução de liberação. 
$O$ controle do potencial poderia ser mais efetivo em filmes de PANI mais compactos, que possuíssem um menor poder de "swelling" (intumescimento) portanto a difusão dentro desta matriz seria dificultada. Assim realizou-se a síntese de um filme de PANI mais lentamente (para se ter uma maior compactação das cadeias poliméricas): $\mathrm{VC}$ entre $-0,2$ e $0,8 \mathrm{~V}$ nos dois primeiros ciclos e os demais até $0,6 \mathrm{~V}$ a $50 \mathrm{mVs}^{-1} \mathrm{em}$ solução aquosa de $0,5 \mathrm{molL}^{-1}$ de anilina e $1,0 \mathrm{molL}^{-1}$ de $\mathrm{HCl}$. O filme depois de sintetizado foi recoberto com $4 \mu \mathrm{L}$ de Náfion, deixado secar ao ar e posto em água deionizada por $12 \mathrm{~h}$ e por fim polarizado a $-0,05 \mathrm{~V}$ em DOPA $0,1 \mathrm{molL}^{-1}$ por $1,5 \mathrm{~h}$. A Figura 27 mostra liberação realizada em água deionizada mantendo-se a membrana a $-0,2 \mathrm{~V}$ durante $2 \mathrm{~h}$ e depois a $0,2 \mathrm{~V}$ por mais algumas horas e comparando esse resultado com o mostrado na Figura 26 e resumido na tabela 9, confirma-se que a membrana sintetizada mais lentamente, ou seja, mais compacta, possui uma maior capacidade de controlar eletroquimicamente a saída de dopamina.

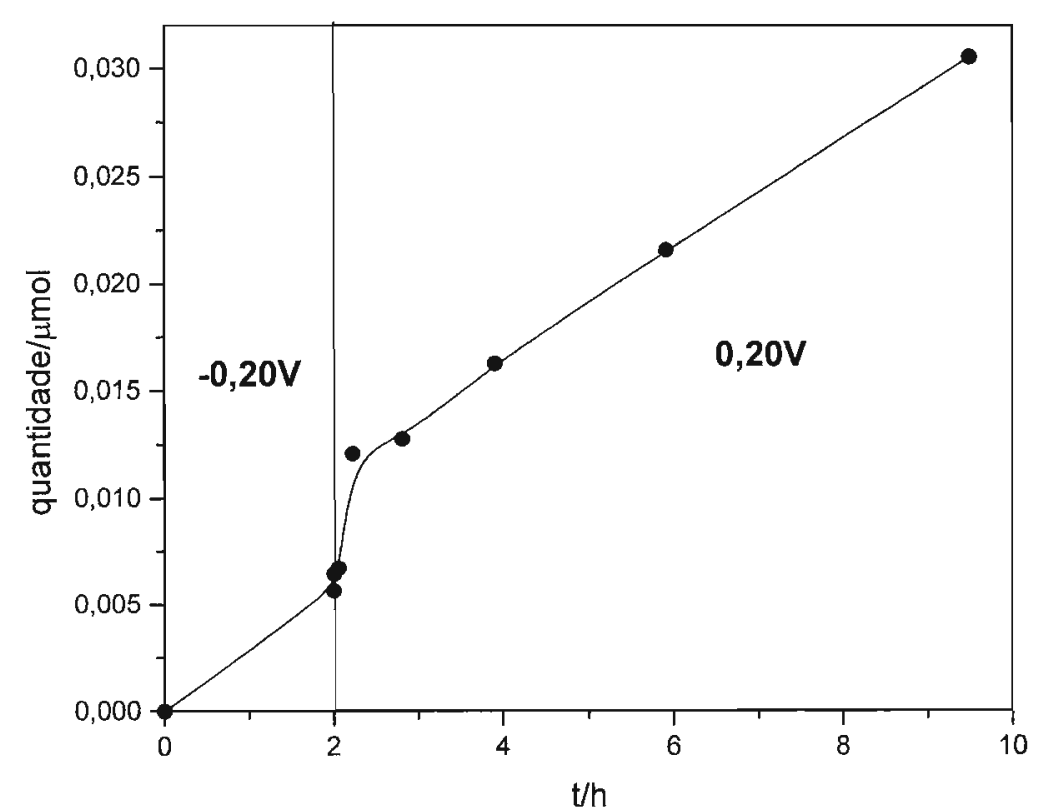

Figura 27 - Efeito do potencial na liberação de DOPA em água deionizada. 
Tabela 9 - Comparação do efeito do potencial na liberação de DOPA a partir de de filmes de polianilina recobertos com Náfion.

\section{filme de PANI}

mais compacto (fig.27)

solução de liberação

$$
\Delta \mathbf{E}^{\mathrm{a}}
$$

$$
\Delta \mathbf{t}^{\mathbf{b}}
$$

$\Delta(\text { DOPA })^{\mathrm{c}}$ $\triangle($ DOPA $)$ em $\%^{d}$ água deionizada

$$
0,40 \mathrm{~V}(\mathrm{de}-0,20 \text { para } 0,20 \mathrm{~V})
$$

$30 \mathrm{~s}$

$$
2,5.10^{-9} \mathrm{~mol}
$$

$112 \%$ menos compacto (fig.25)

$$
\begin{gathered}
\mathrm{HCl} 0,1 \mathrm{molL}^{-1} \\
0,40 \mathrm{~V}(\mathrm{de}-0,20 \mathrm{~V} \text { para } 0,20 \mathrm{~V}) \\
150 \mathrm{~s}
\end{gathered}
$$$$
6,35 \cdot 10^{-9} \mathrm{~mol}
$$

$7 \%$

\footnotetext{
a variação entre os potencais catódicos e anódicos aplicados ao sistema.

${ }^{b}$ intervalo de tempo entre a última medida (último espectro) da concentração de DOPA em solução com a membrana reduzida e a primeira no potencial anódico.

${ }^{c}$ DOPA liberada em $\Delta t$.

d \% de DOPA liberada em $\Delta \mathrm{t}$, referente ao total em solução até a mudança de potencial.
}

O próximo parâmetro estudado foi a quantidade de polianilina no sistema. Todos os experimentos anteriores foram realizados com o filme de polianilina eletrodepositado potenciodinamicamente durante 20 ciclos, então se decidiu começar a variar o número de ciclos em torno deste valor, para avaliar primeiramente a quantidade de dopamina liberada. Na Figura 28 são mostradas as curvas de liberação para membranas sintetizadas com diferentes tempos de polimerização: 5, 10, 20 e 40 ciclos. Não se tem uma relação diretamente proporcional do número de mols liberado com a quantidade de polímero condutor depositado. Tal comportamento pode ser explicado considerando que a variação de espessura do filme foi muito pequena, ou seja, é preciso considerar a razão espessura/área $(\delta / \mathrm{A}=\mathrm{L})$ do filme como esquematizado na Figura 29. Existirá então um intervalo de valores para $\mathrm{L}$ - considerando A constante - em que a quantidade de dopamina incorporada superficialmente $(S)$ será muito maior do que aquela presente no interior da membrana (I), portanto, considerando que S (para uma mesma área) tem uma variação (s) de experimento para experimento, pode ser que "s" seja da mesma ordem de grandeza que "I". Assim, neste intervalo a observação do efeito de filmes mais espessos será dificultada. Em contrapartida, também deverá existir um valor limite de L (Lm), acima do qual um aumento na espessura do filme será refletido num maior número de mols de dopamina liberada. 


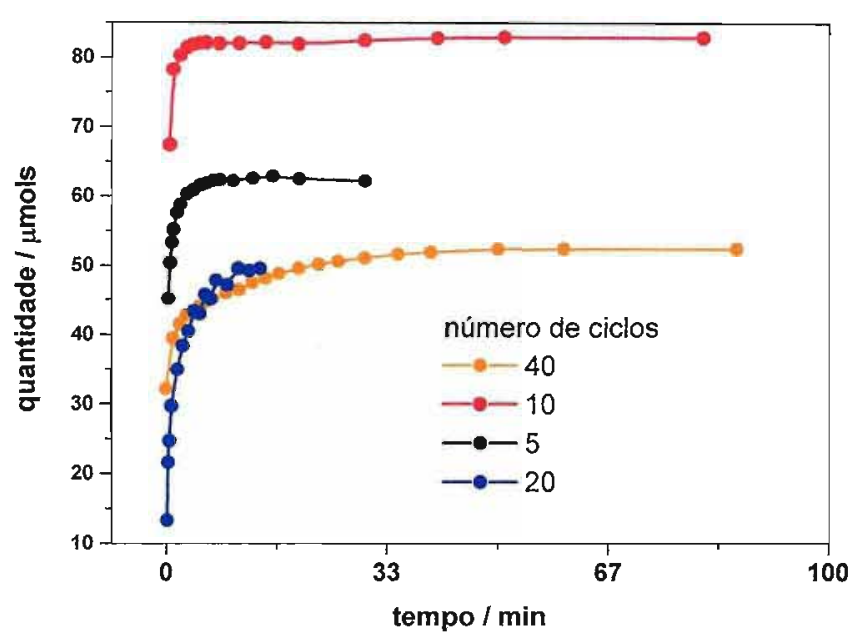

Figura 28 - Curvas de liberação de dopamina a $0,18 \mathrm{~V}$ em solução aquosa de $\mathrm{HCl}$ $0,1 \mathrm{molL}^{-1}$ para membranas preparadas com diferentes quantidades de polianilina. Notar que a quantidade de polianilina foi controlada com o número de ciclos na voltamentria cíclica.

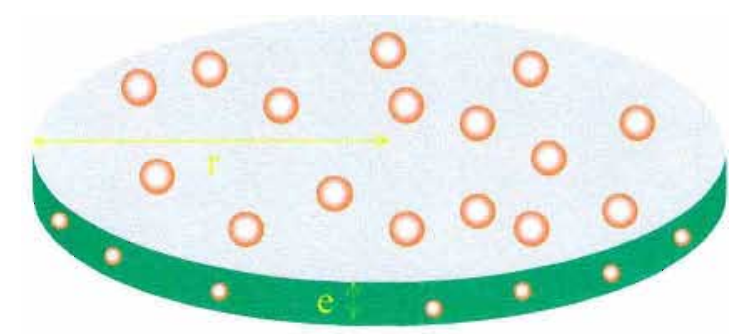

Dopamina incorporada superficialmente

Dopamina incorporada no interior do filme

Figura 29 - Esquema de um filme de polianilina carregado com dopamina, com espessura $\delta$ e eletrosintetizado sobre um disco de platina de raio $r$.

A Figura 30 mostra que a despeito da variação na quantidade de dopamina liberada, o perfil de liberação é diferente para cada quantidade de polímero condutor, sendo que os filmes com mais polianilina geraram uma liberação mais lenta, correspondéndo à saída da dopamina incorporada nas regiões mais internas da membrana e que, portanto tem um maior caminho até alcançar a solução. Na Figura 30 também se comparam dois filmes sintetizados com 40 ciclos, e se elimina a possibilidade de que o tempo de dopagem (10 min), estabelecido anteriormente para filmes sintetizados com 20 ciclos, não tenha sido suficiente para se atingir o carregamento máximo da membrana. 
A Figura 30 ainda mostra o perfil de liberação de dopamina a partir de um eletrodo recoberto somente com Náfion. Todo o procedimento experimental foi igual, exceto pela ausência do polímero condutor e tem-se que a camada de Náfion também é responsável pelo acumulo de dopamina no sistema PANI/Náfion. Porém, mantendo-se constante a espessura desta membrana, como nos experimentos aqui mostrados, qualquer diferença no perfil de liberação é devido ao polímero condutor, e sendo a quantidade liberada a partir do Náfion próxima àquela liberada pelo sistema PANI/Náfion, mais uma vez fica reforçada a idéia de que se está trabalhando com muito pouco polímero condutor e que efetivas mudanças no perfil de liberação só serão alcançadas com filmes contendo uma maior quantidade de polianilina.

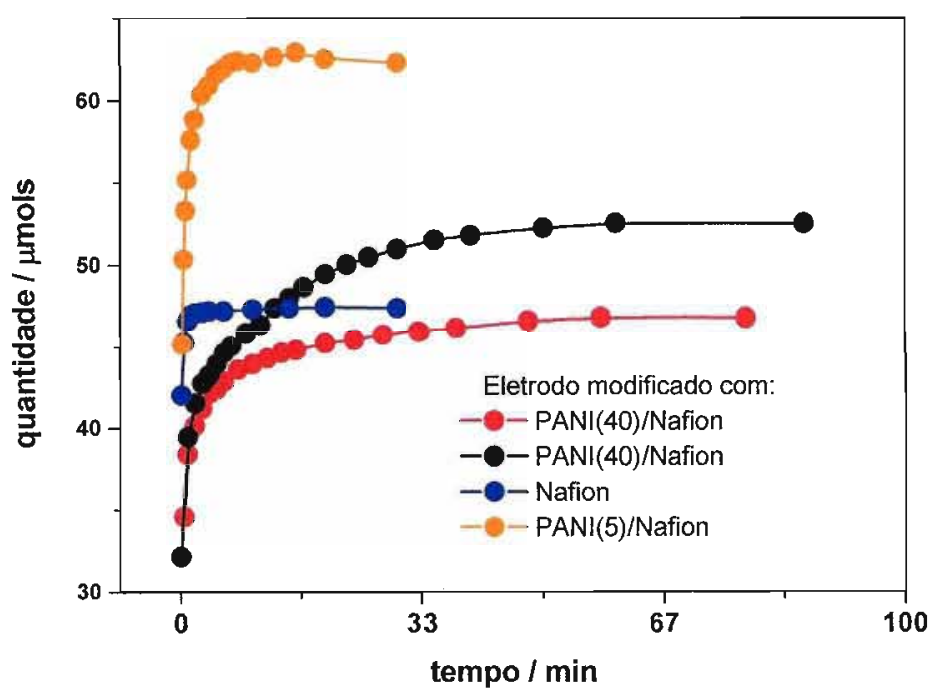

Figura 30 - Curvas de liberação de dopamina a $0.18 \mathrm{~V}$ em solução aquosa de $\mathrm{HCl}$ $0,1 \mathrm{molL}^{-1}$ para diferentes membranas. Em azul, a liberação a partir de um eletrodo recoberto somente com uma camada de Náfion. PANI(X)/Náfion se refere a membranas de polianilina sintetizadas com $X$ ciclos e recobertas com Náfion. A curva PANI(40)/Náfion em preto foi realizada após um tempo de carregamento de $10 \mathrm{~min}$, enquanto que a PANI(40)/Náfion em vermelho após $60 \mathrm{~min}$ de carregamento.

Tendo em vista o discutido no parágrafo anterior, é importante situar as membranas sintetizadas quanto à cinética de polimerização da anilina. É conhecido ${ }^{17}$ que a polianilina crescida por voltametria cíclica possui um mecanismo auto-catalítico de polimerização, onde a inclinação da curva que acompanha o aumento de massa em função do tempo se mantém crescente. Porém este comportamento auto-catalítico só é visto a partir de um determinado momento na síntese, ou seja, antes a velocidade de crescimento da polianilina não permite que se tenham filmes muito diferentes (em 
quantidade) em diferentes tempos de polimerização. Na Figura 31 é mostrada a carga total versus o tempo de polimerização da anilina nas condições em que foram sintetizadas as membranas para a liberação, e na Figura 32, os tempos de polimerização referentes a essas membranas. Pode-se dizer então, que o filme testado com maior quantidade de polianilina está somente no começo do crescimento auto-catalítico deste polímero, assim se reforça a idéia de que efetivas diferenças no perfil e na quantidade de dopamina liberada poderá ser vista variando-se o tempo de polimerização (número de ciclos) num intervalo superior ao testado até aqui $(\sim 1600 \mathrm{~s})$.

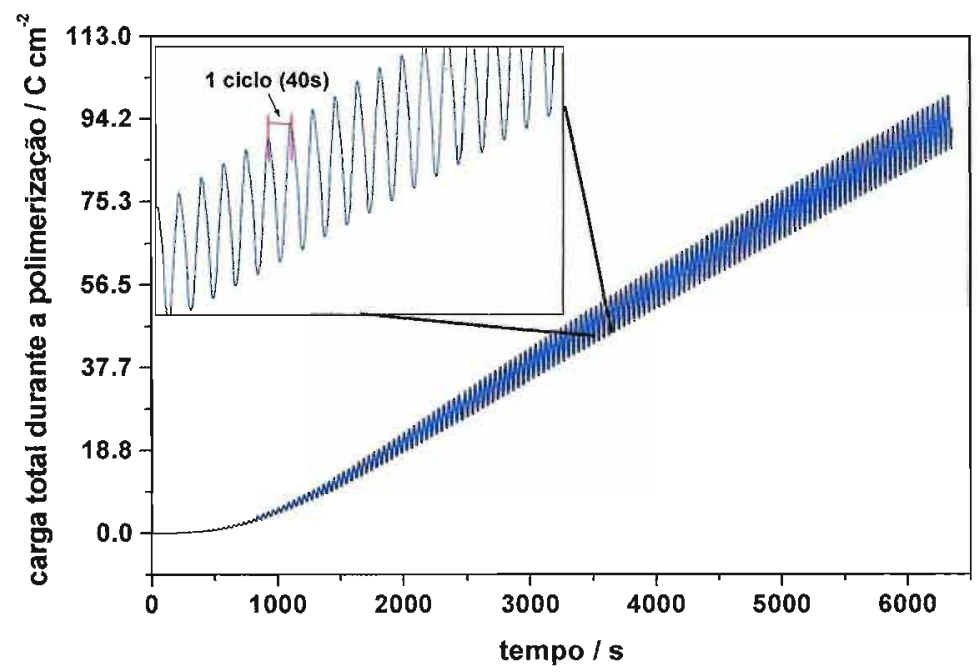

Figura 31 - Cinética de polimerização (condições na parte experimental) da anilina. A curva foi construída a partir dos voltamogramas da síntese, onde a curva potencial $\mathrm{X}$ corrente foi transformada em tempo X corrente e integrada.

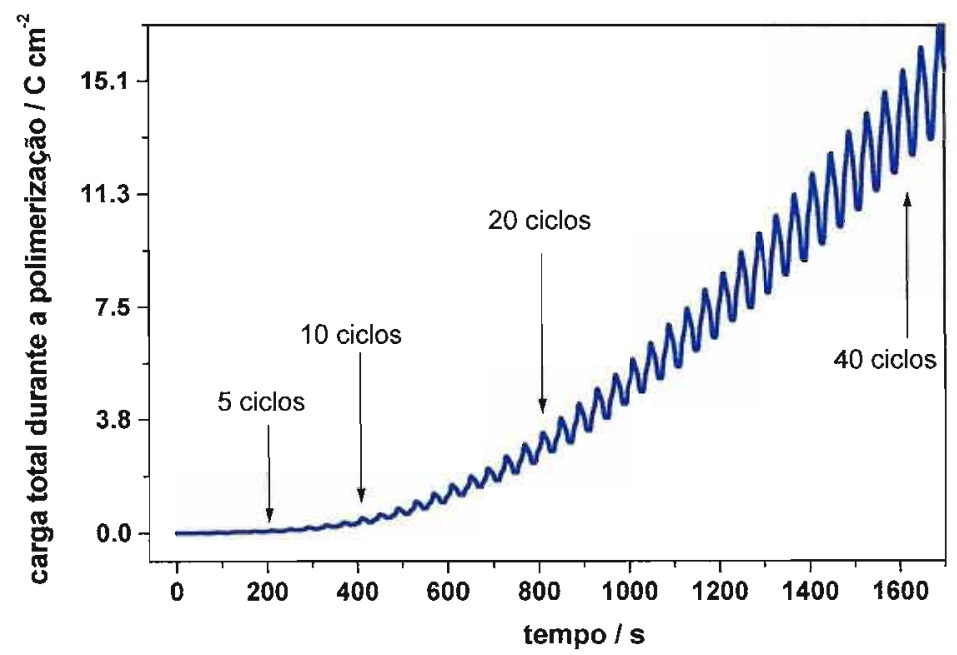

Figura 32 - Detalhe da figura 25 mostrando o ponto referente a cada membrana testada. 
Com a técnica de microbalança eletroquímica a cristal de quartzo (MECQ) foi possível explorar o sistema PANI/Náfion no seu aspecto mais fundamental. Portanto, antes de se prosseguir na parametrização do sistema, foi verificada a suposição inicial de que o filme de Náfion atua como uma membrana que impede a passagem de espécies negativamente carregadas, lembrando que a veracidade de tal suposição é essencial para se obter um sistema que controle eletroquimicamente o carregamento e a liberação de dopamina protonada (um cátion). A série de experimentos mostrada a seguir tem, então, o propósito de mostrar o papel do Náfion neste sistema polimérico de duas camadas.

A Figura 33 mostra a síntese por voltametria cíclica de polianilina sobre eletrodo de quartzo recoberto com ouro acompanhada pela variação de freqüência. No detalhe da figura são mostrados os voltamogramas referentes à síntese. Este conjunto de dados mostrou o comportamento esperado, uma vez que, globalmente, a diminuição da freqüência significa o aumento de massa sobre o eletrodo no decorrer da eletropolimerização e como a síntese foi potenciodinâmica, os ciclos de oxidação e redução do polímero causam o perfil oscilante da freqüência em função do tempo.

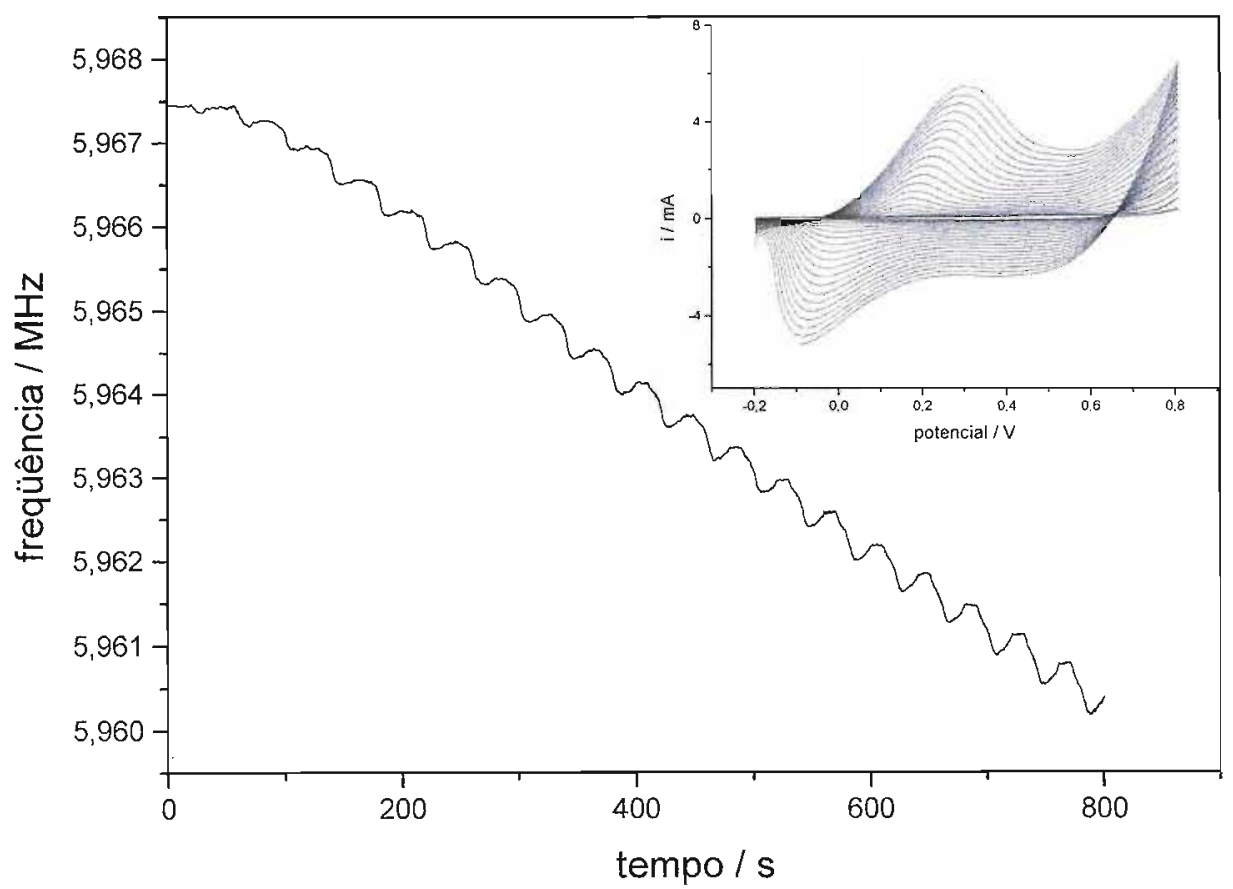

Figura 33 - Variação de freqüência durante a eletropolimerização de anilina sobre eletrodo de ouro. Inserto: Voltamogramas da síntese em solução $0,5 \mathrm{~mol}, \mathrm{~L}^{-1}$ de anilina + 1,0mol. $\mathrm{L}^{-1}$ de HCl. $\mathrm{v}=50 \mathrm{mV} . \mathrm{s}^{-1}$. 
Após a síntese, foi verificado o comportamento do eletrodo recoberto com polianilina frente sucessivos ciclos de oxidação/redução a $0,4 /-0,2 \mathrm{~V}$ em solução aquosa de $\mathrm{HCl}$ 1,0mol.L ${ }^{-1}$. A Figura 34 traz a $\Delta$ f em função do estado de oxidação do sistema: tem-se o aumento da massa (diminuição da freqüência) com a oxidação do polímero condutor e a diminuição da massa (aumento da freqüência) conforme se reduz o sistema. Este comportamento da massa é o esperado devido à conhecida ${ }^{29}$ compensação de cargas que se faz na polianilina, dopada com $\mathrm{HCl}$, predominantemente através da movimentação de ânions cloreto acompanhados de moléculas de água.

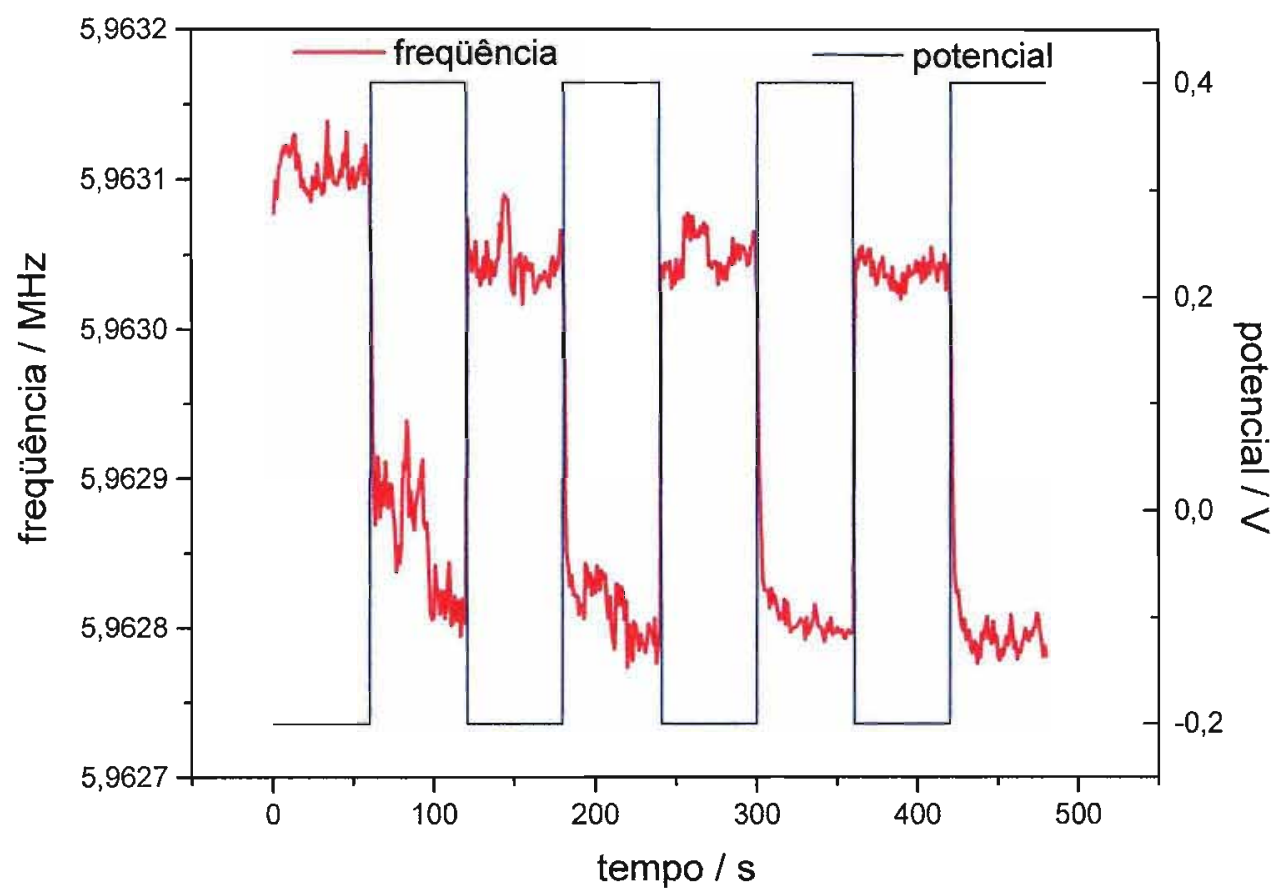

Figura 34 - Variação de freqüência de vibração de um eletrodo de ouro sobre quartzo recoberto com polianilina em função do potencial aplicado ao sistema. Solução: $\mathrm{HCl} 1,0$ mol. $\mathrm{L}^{-1}$.

Depois deste teste foi formada uma camada de Náfion sobre a polianilina e o sistema bipolimérico foi submetido novamente a ciclos de oxidação/redução em solução aquosa de $\mathrm{HCl} 1,0 \mathrm{~mol} . \mathrm{L}^{-1}$, o resultado, que pode ser visto na Figura 35, comprova a suposição inicial de que o Náfion é capaz de barrar a passagem de ânions e dessa forma inverter o processo de compensação de cargas na polianilina, forçando a entrada e a saída de prótons (e água) durante a redução e a oxidação respectivamente. Neste ponto é importante destacar que embora o experimento mostrado na Figura 35 valide o sistema para a sua aplicação com dopamina, o modo de se formar o filme de Náfion não se mostrou reprodutível, ou seja, às vezes era necessária mais de uma camada do polímero 
para formar uma cobertura eficiente sobre a polianilina como mostraram os dados da MECQ.

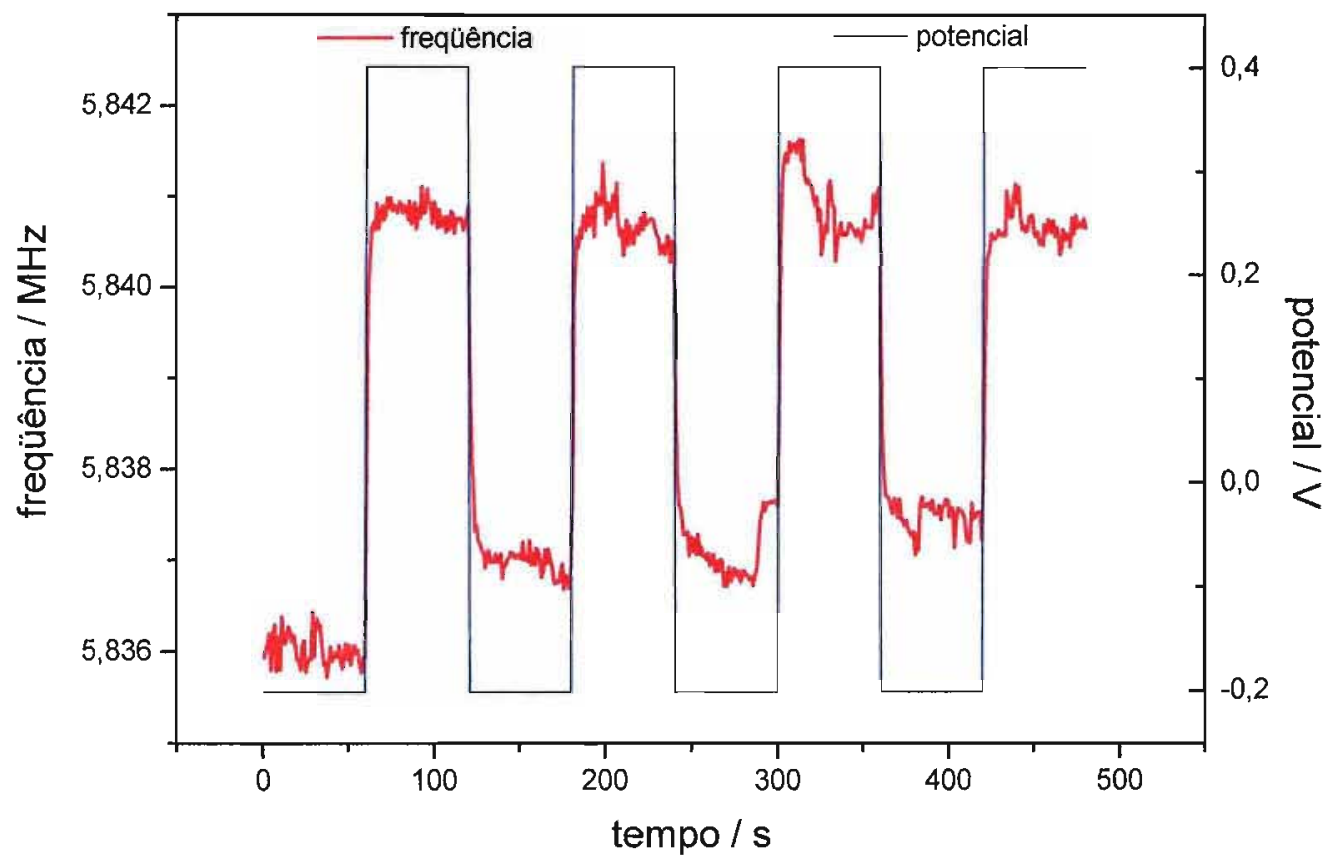

Figura 35 - Variação de frequiência de vibração de um eletrodo de ouro sobre quartzo recoberto com polianilina/Náfion em função do potencial aplicado ao sistema. Solução: $\mathrm{HCl} 1,0$ mol.L $\mathrm{L}^{-1}$

Com o sistema a partir do qual se obteve o resultado mostrado na Figura 35 continuaram-se os testes a fim de se poder caracterizar também os processos de dopagem e liberação da dopamina através da MECQ. Todos os resultados apresentados nesta sessão consideram diretamente a variação de freqüência do sistema e esta é qualitativamente associada à variação de massa. Como será mostrado mais adiante não foi necessária a quantificação desta relação freqüência - massa, muito menos a validação da técnica para o sistema estudado através de impedância eletroacústica.

O carregamento do sistema foi realizado em solução $0,1 \mathrm{~mol} . \mathrm{L}^{-1}$ de dopamina a $-0,2 \mathrm{~V}$. Esperava-se a diminuição da freqüência com o tempo de carregamento devido à incorporação de dopamina no sistema, porém o que foi verificado foi o oposto: um leve aumento da freqüência de vibração do sistema como é mostrado na Figura 36 . De qualquer forma continuou-se o experimento com o teste de liberação controlada da dopamina em solução de $\mathrm{HCl} 1,0 \mathrm{~mol} . \mathrm{L}^{-1} \mathrm{e}$, de acordo com o resultado que aparece na Figura 37, o comportamento do sistema também se mostrou contrário ao esperado. Primeiramente, o sistema PANI/Náfion foi mantido reduzido, num potencial de $-0,2 \mathrm{~V}$, 
pois assim reteria a dopamina ou a liberaria com uma velocidade mais baixa do que aquela esperada quando se tivesse a polianilina oxidada. De fato, ao se oxidar a polianilina (figura 37) observou-se a diminuição abrupta da freqüência, mostrando que, globalmente o sistema tinha ganhado massa durante o processo de compensação de carga, e isto implica necessariamente na participação (predominante) de íons cloreto. Assim não foi possível demonstrar a entrada nem a saída de dopamina do filme.

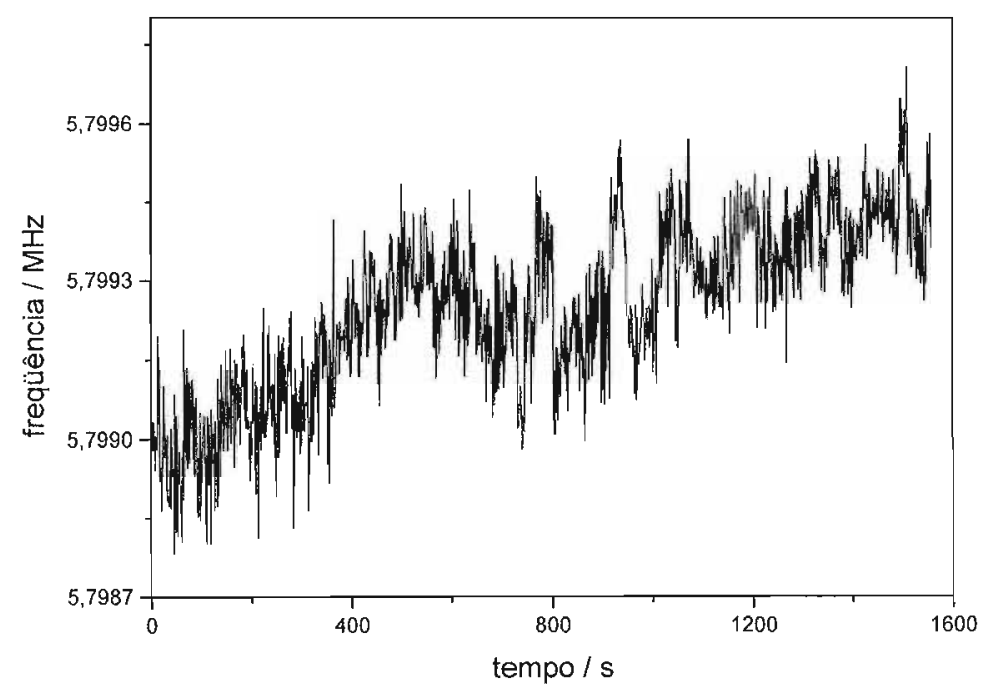

Figura 36 - Polarização (a $-0,20 \mathrm{~V}$ ) do filme de polianilina/Náfion em solução 0,1 mol. $L^{-1}$ de dopamina.

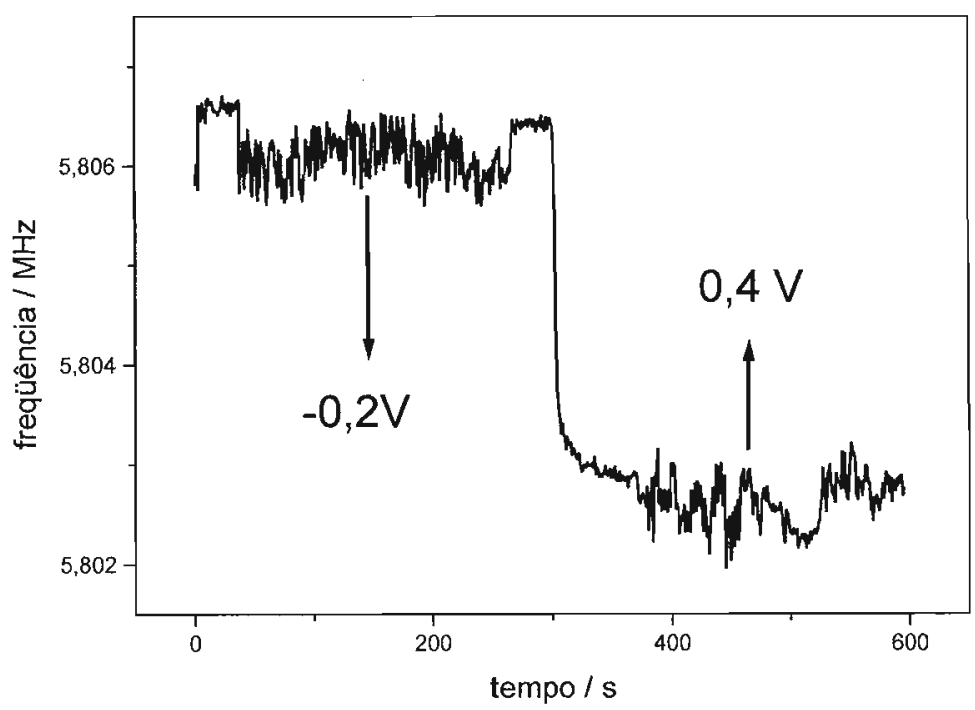

Figura 37 - Teste de liberação controlada de dopamina em solução aquosa de HCl 1,0 $\mathrm{mol}^{-1}$. 
O comportamento visto na Figura 37 sugere que de alguma forma a cobertura de Náfion perdeu sua eficiência durante o procedimento; e para comprovar esta hipótese, ou seja, para mostrar que, novamente, o $\mathrm{Cl}^{-}$é que estava preferencialmente compensando carga durante os processos de oxi-redução da polianilina, realizou-se mais uma vez para os mesmos ciclos de redução/oxidação em solução de $\mathrm{HCl} 1,0 \mathrm{~mol} . \mathrm{L}^{-1}$ e na Figura 38 mostra-se este resultado. Verificou-se então o mesmo comportamento (comparar com a Figura 34) obtido antes de se recobrir o sistema com Náfion. Aparentemente são duas as razões para a polianilina ter sua compensação de cargas original restaurada: i. ou a camada de Náfion se desprendeu da polianilina; ii: ou durante os ciclos de oxidação/redução da polianilina a movimentação do polímero condutor causou danos ("buracos") na cobertura de Náfion.

Independente da razão pela qual o sistema não funciona adequadamente, julgouse tal fato suficiente para propor que a bicamada polianilina/Náfion, na forma como foi idealizada inicialmente, não é de fato um sistema promissor para incorporação e liberação eletroquimicamente controlada de dopamina protonada.

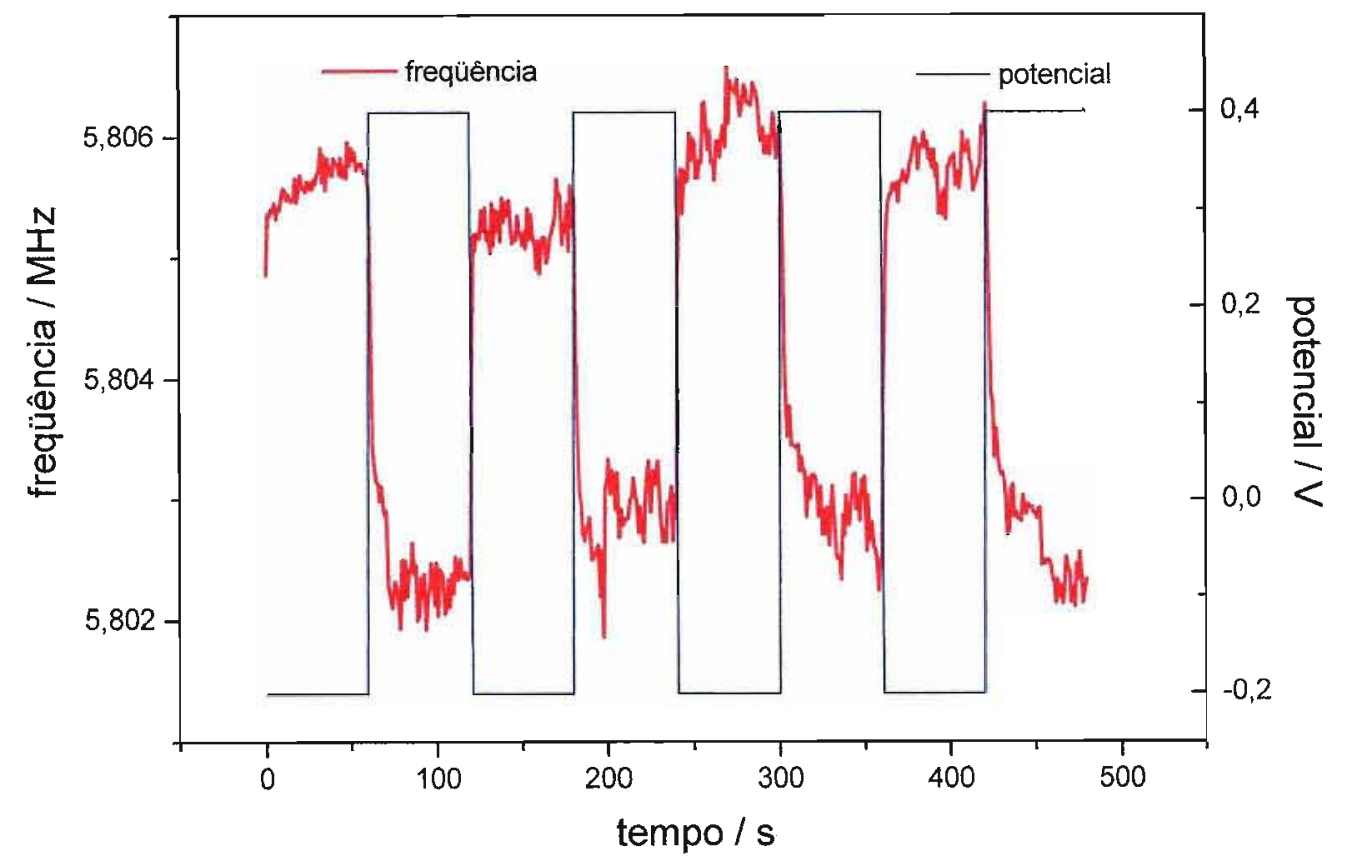

Figura 38 - Variação de freqüência de vibração de um eletrodo de ouro sobre quartzo recoberto com polianilina/Náfion em função do potencial aplicado ao sistema. Solução: HCl 1,0 mol. $\mathrm{L}^{-1}$. 


\subsection{3 - Mais estudos (e conclusões) sobre sistemas da Geração I}

Nas seções anteriores foram apresentados os resultados de dois sistemas de liberação controlada (Geração I) utilizando polianilina. Em ambos, os casos limitações se colocaram à frente da completa caracterização dos sistemas; limitações como a irreprodutibilidade do sistema ou a instabilidade (física ou química) de partes do sistema. Porém, é importante sempre se ter em mente que o objetivo principal desta tese é avaliar (o mais detalhadamente possível) sistemas-modelo baseados em polímeros condutores para dispositivos de liberação controlada eletroquimicamente de drogas. Assim, toda a discussão e conclusão aqui apresentadas podem vir a ser de grande importância no desenvolvimento tecnológico desta classe de dispositivos. Em paralelo ao estudo dos sistemas até aqui mostrados, foram realizados outros testes com diversos sistemas poliméricos e drogas-modelo a fim de se obter resultados mais promissores para futuras aplicações "in vivo" como é o desejo final de todos envolvidos neste projeto. A tabela 10 traz de forma resumida os sistemas testados, nenhum deles forneceu informação ou detalhamento que justificasse seções como as duas anteriores, pois também falharam em algum aspecto vital para a continuidade de sua caracterização, porém o conjunto de experiências (negativas) a respeito da assim chamada "Geração I" foi uma grande motivação para a procura de uma arquitetura / mecanismo de funcionamento diferente para sistemas poliméricos contendo polímeros condutores e que sejam capazes de controlar eletroquimicamente a liberação de importantes princípios ativos (como morfina e anti-virais).

Esta próxima geração deveria então fornecer alternativas de sistemas, no mínimo mais reprodutíveis e capazes de incorporar e liberar moléculas maiores e em maior quantidade que a maioria das drogas-modelo estudas nesta tese e na maioria dos trabalhos já publicados. Na seção seguinte, então, se apresenta esta nova geração, sua idéia inicial e proposta de trabalho, que, como será visto até o final desta tese, culminou num sistema-modelo que de fato pode ser a base de futuros dispositivos comerciais. 
Tabela 10 - Resumo dos resultados obtidos para sistemas de liberação controlada eletroquimicamente de Geração I.

\begin{tabular}{|c|c|c|c|}
\hline \multicolumn{2}{|c|}{ Sistema } & Observação & Aonde falhou: \\
\hline Polímero(s) & $\begin{array}{l}\text { Droga- } \\
\text { modelo }\end{array}$ & & \\
\hline $\begin{array}{c}\text { polianilina } \\
\text { sulfonada (SPAN) }\end{array}$ & $\begin{array}{l}\text { Dopamina } \\
\text { protonada }\end{array}$ & $\begin{array}{l}\text { A SPAN, por ser um polímero } \\
\text { condutor auto-dopado tem sua } \\
\text { compensação de carga realizada } \\
\text { fundamentalmente por cátions. }\end{array}$ & $\begin{array}{c}\text { Foi verificada a decomposição } \\
\text { da dopamina sobre a SPAN } \\
\text { oxidada (eletrocatálise). }\end{array}$ \\
\hline $\begin{array}{c}\operatorname{poli}(N- \\
\text { metilpirrol }) / \mathrm{PSS}^{-}\end{array}$ & $\begin{array}{l}\text { Dopamina } \\
\text { protonada }\end{array}$ & $\begin{array}{c}\text { Polímero condutor dopado com } \\
\text { dopante primário polimérico (PSS }) \\
\text { tem sua compensação de carga } \\
\text { realizada fundamentalmente por } \\
\text { cátions. }\end{array}$ & $\begin{array}{l}\text { Baixo controle eletroquímico } \\
\text { da liberação. }\end{array}$ \\
\hline polipirrol & nevirapina & $\begin{array}{l}\text { A nevirapina é um importante anti- } \\
\text { viral, catiônico quando protonada (ver } \\
\text { Figura 39). Neste caso o polipirrol foi } \\
\text { dopado com DBSA, tornando o } \\
\text { sistema capaz de trocar principalmente } \\
\text { cátions. }\end{array}$ & $\begin{array}{c}\text { Não houve liberação da droga } \\
\text { em solução. }\end{array}$ \\
\hline polipirrol/PSS & nevirapina & $* * * * * * * * * * * *$ & $\begin{array}{c}\text { Não houve liberação da droga } \\
\text { em solução. }\end{array}$ \\
\hline polipirrol & Íon Lítio & Polipirrol dopado com DBSA. & $\begin{array}{l}\text { Irreprodutibilidade nos perfis } \\
\text { de liberação de lítio em } \\
\text { solução (determinados por } \\
\text { absorção atômica). Não foi } \\
\text { possivel determinar nenhum } \\
\text { controle eletroquímico na } \\
\text { liberação. }\end{array}$ \\
\hline
\end{tabular}

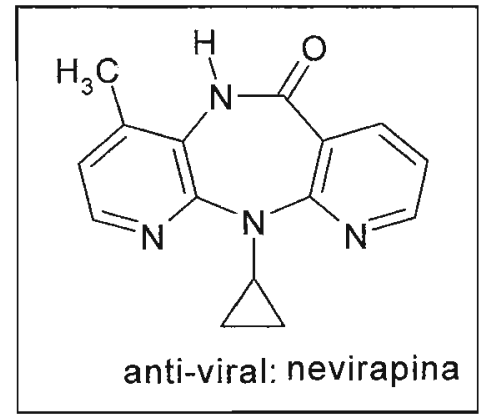

Figura 39 - Estrutura do anti-viral nevirapina. 
4.3 - Sistemas de liberação controlada eletroquimicamente de drogas baseado em polímeros condutores: Geração II

A clássica utilização de hidrogéis em sistemas de liberação controlada ${ }^{53}$ e os trabalhos de Wallace ${ }^{64,71}$ mostrando a síntese de polipirrol em uma rede tridimensional de poliacrilamida reticulada (PAAM), resultaram numa nova metodologia para a incorporação e liberação controlada eletroquimicamente de drogas.

A proposta inicial foi de que tais compósitos seriam capazes de modular a velocidade de liberação eletroquimicamente, isto ocorreria devido à mudança de volume que o polímero condutor sofre junto com a alteração do seu estado de oxidação, causado principalmente pela movimentação iônica e de solvente - propriedade de músculo $\operatorname{artificial}^{31}$. Uma vez que no compósito, o polímero condutor percola uma matriz porosa, espera-se que o espaço livre nos poros seja função do estado de oxidação do polímero condutor e consequentemente a velocidade de difusão de moléculas neste sistema também, a Figura 40 traz esta proposta inicial de funcionamento. Assim, não se procura extremos de funcionamento como a propriedade de ligar/desligar como especulado para os sistemas de Geração I, mas se pretendeu estudar condições em que o compósito hidrogel / polímero condutor responda ao potencial aplicado, produzindo diferentes velocidades de liberação de drogas. A priori, as vantagens deste tipo de sistema, comparado com a Geração I, são: i. a possibilidade de se incorporar e liberar drogas neutras, além das iônicas, já que a incorporação/liberação não estará diretamente relacionada com o fluxo iônico devido à mudança de estado de oxidação do PC; ii. as baixas concentrações de droga liberada não seriam mais um fator limitante, visto que os hidrogéis podem ser carregados com grande quantidade do fármaco, ou pode-se facilmente utilizá-los como membrana separando compartimentos doadores e receptores de drogas em dispositivos de liberação e iii. em polímeros condutores a maior molécula incorporada foi o ATP, e devido à sua morfologia, drogas maiores não poderiam ser incorporadas, porém, até proteínas podem difundir em hidrogéis, o que torna o sistema bem versátil quanto ao tamanho dos fármacos candidatos à liberação. 


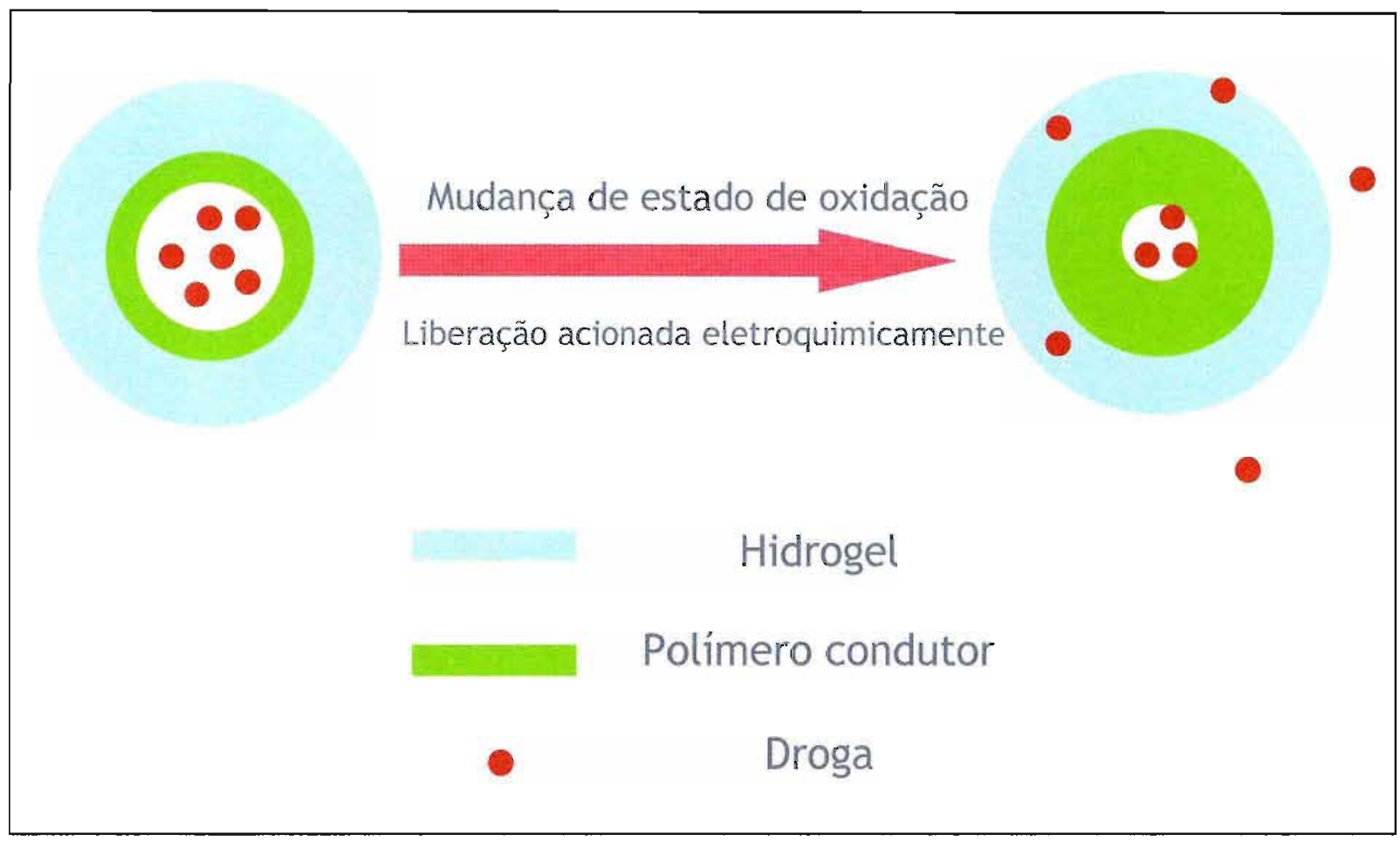

Figura 40 - Esquema da proposta inicial para o funcionamento de um compósito de polímero condutor / hidrogel em sistemas de liberação controlada. A mudança de estado de oxidação do polímero condutor no interior da matriz porosa do hidrogel, provocaria uma mudança de volume do polímero condutor conseqüente alteração na velocidade de liberação da droga incorporada neste sistema.

\subsection{1 - Redes condutoras semi-interpenetrantes de polianilina/ poliacrilamida}

Para se alcançar o objetivo proposto na seção anterior, foi escolhido o compósito formado entre a polianilina e a poliacrilamida quimicamente reticulada. Neste compósito, primeiramente, a matriz isolante de poliacrilamida reticulada quimicamente (detalhes na parte experimental) é sintetizada para servir como meio para o crescimento eletroquímico da polianilina (matriz hospedeira). A inserção de um contato elétrico (fio de platina) no hidrogel o transforma em eletrodo trabalho numa célula eletroquímica convencional, assim conseguiu-se sintetizar eletroquimicamente a polianilina no interior da matriz porosa da poliacrilamida. A Figura 41 mostra esquematicamente etapas desta síntese e uma foto do compósito depois de pronto. 


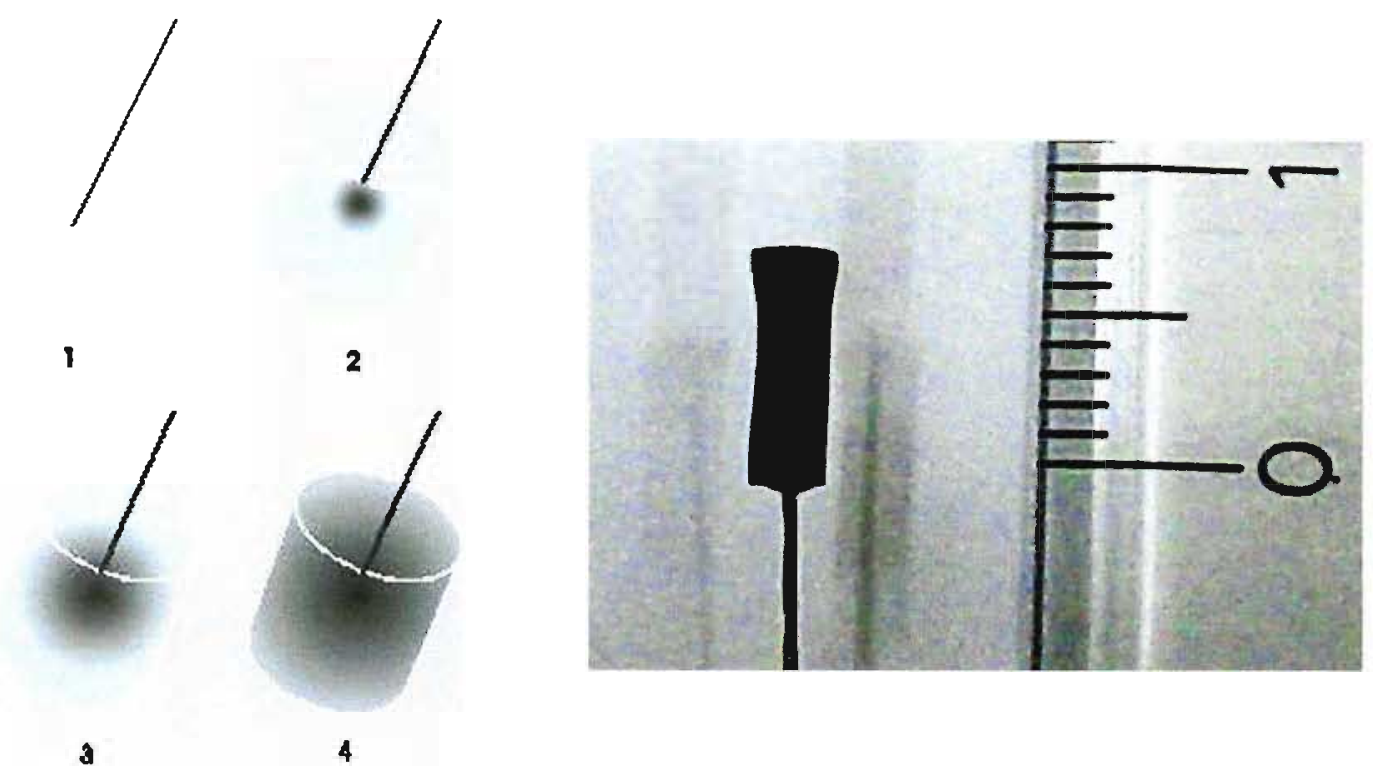

Figura 41 - Esquerda: esquema de preparação do compósito PC/Hidrogel. 1. Hidrogel de poliacrilamida (transparente) em forma cilíndrica (forma do molde) com um fio de Pt imobilizado. 2-4. Sequiência de crescimento do PC (polianilina) no hidrogel. No final do processo, o compósito adquiri coloração preta. Direita: foto do compósito pronto e seu tamanho real.

O compósito assim formado constitui uma rede condutora semi-interpenetrante: o termo semi-interpenetrante utilizado na denominação deste compósito, foi emprestado da terminologia dos hidrogéis e se refere a compósitos formados por dois polímeros onde um deles está reticulado e outro não. Uma rede interpenetrante seria um termo para compósitos poliméricos onde os dois (ou mais) polímeros possuem ligações cruzadas e suas redes se interpenetram. A Figura 42 mostra um voltamograma típico desta rede, justificando o termo "condutora" na sua denominação. Para se atingir um compósito completamente (visualmente) preenchido com a polianilina, é necessária uma considerável quantidade de polímero condutor (este parâmetro será mais detalhado a seguir), assim para se obter um voltamograma que mostre os processos redox da polianilina, a velocidade de varredura tem que ser pequena o suficiente para permitir a difusão das espécies no interior deste novo material. De qualquer forma, o voltamograma da Figura 42 é um primeiro indício da formação do polímero condutor no interior da poliacrilamida, um vez que mostra o pico $(\sim 0,25 \mathrm{~V})$ característico da passagem da forma leucoesmeraldina para a esmeraldina na oxidação do polímero condutor. Um segundo pico que pode ser visto ao redor de $0,50 \mathrm{~V}$ está associado ao aparecimento de ligações cruzadas na polianilina ${ }^{15}$ (processo que pode ocorrer até em 
temperaturas ordinárias na presença de oxigênio), uma vez que a relação entre estes picos muda com o tempo: o primeiro pico diminui (relacionado à oxidação de partes não-reticuladas da polianilina) e o segundo aumenta conforme se aumenta o tempo de exposição do compósito ao ar. Porém, de qualquer forma, pode-se dizer que o compósito tem boa estabilidade química, já que 2 meses depois de sintetizado mantém quase inalterada sua característica condutora.

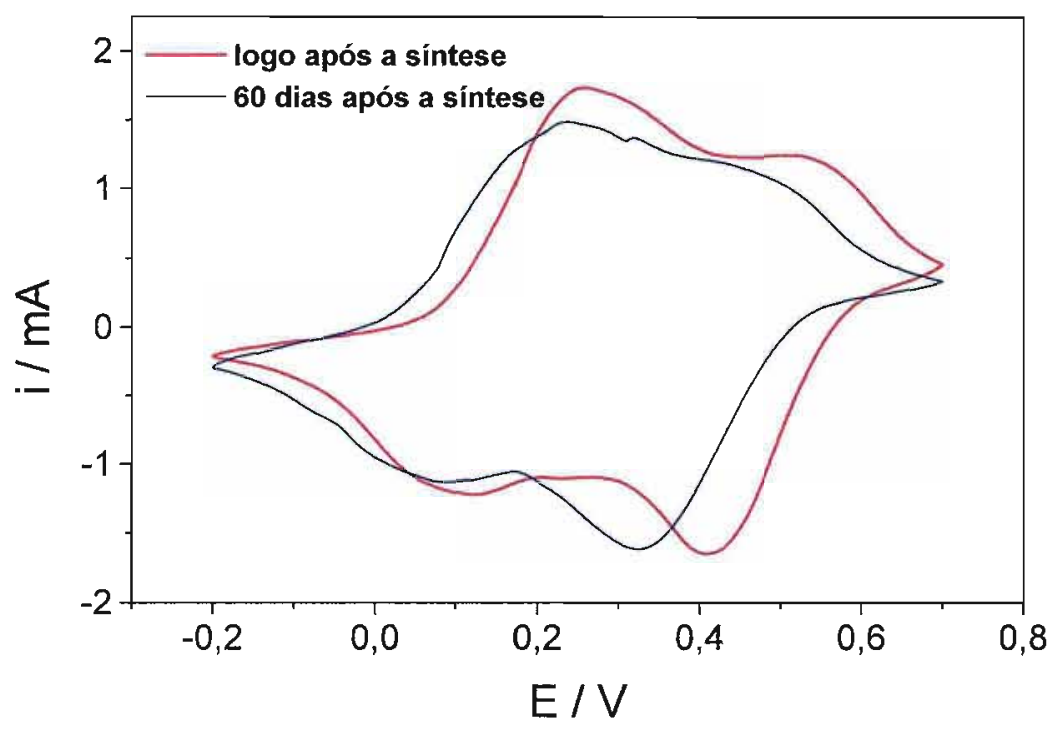

Figura 42 - Voltamogramas cíclicos de um compósito de polianilina/poliacrilamida em solução de $\mathrm{HCl} 0,1 \mathrm{~mol} \cdot \mathrm{L}^{-1} \cdot \mathrm{v}=1 \mathrm{mV} \cdot \mathrm{s}^{-1}$

Por sua rapidez e capacidade de controle dos processos eletroquímicos escolheuse a síntese potenciostática (a $0,75 \mathrm{~V}$ ) para se obter os compósitos. O perfil cronoamperométrico típico de uma síntese potenciostática pode ser visto na Figura 43; a alta e crescente corrente anódica indica a facilidade com a qual o polímero condutor cresce dentro do hidrogel: o aumento praticamente linear da corrente em função do tempo de polimerização é devido ao proporcional aumento da área eletroativa no material (ver o esquema da Figura 41). Outro destaque na Figura 43 é o aparecimento de duas fases de crescimento da polianilina: a primeira se caracteriza por um aumento mais acentuado da corrente em função do tempo e pode ser atribuído ao crescimento do polímero condutor diretamente sobre a superfície metálica. Após o total recobrimento do fio de platina inserido no hidrogel, a polianilina começa a se ramificar por toda estrutura com uma velocidade de crescimento praticamente constante, porém um pouco mais lenta do que sua polimerização na platina, esta é a segunda fase do crescimento do 
polímero condutor na poliacrilamida. Em futuras seções serão mostrados e discutidos mais perfis cronoamperométricos relacionados à síntese de polianilina em matrizes de poliacrilamida com diferentes tamanhos de poro.

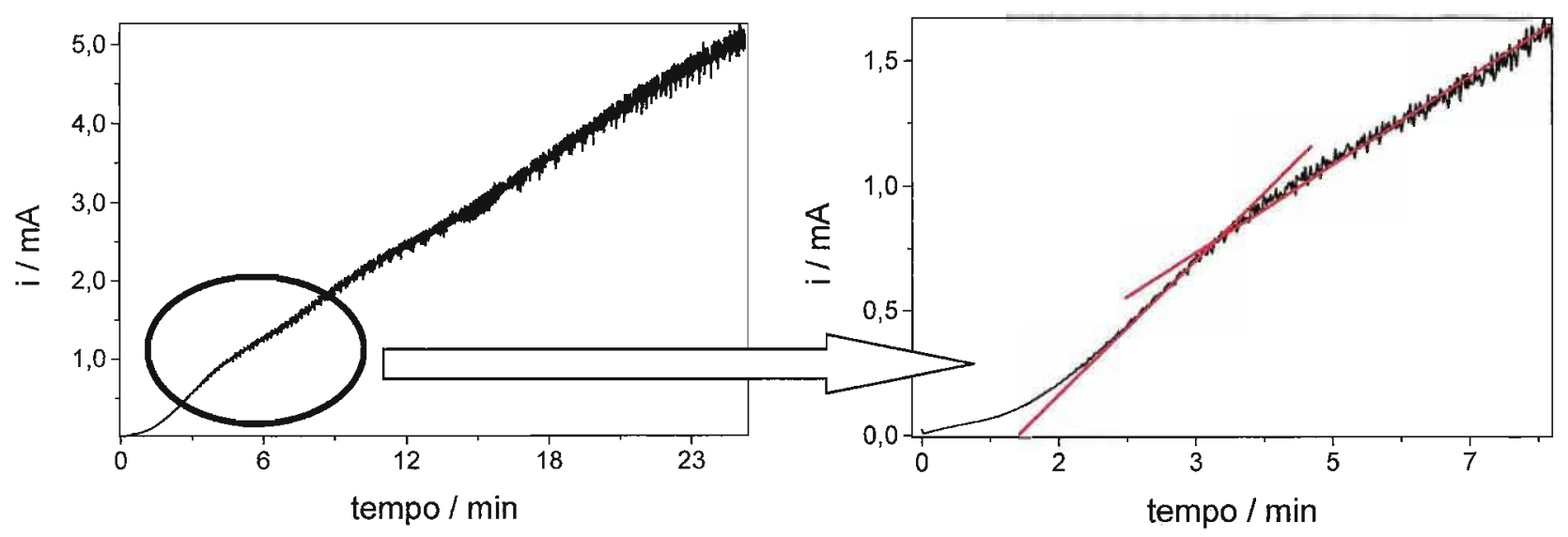

Figura 43 - Esquerda: Cronoamperograma típico da síntese potenciostática $(0,75 \mathrm{~V})$ de polianilina no interior de hidrogéis de poliacrilamida reticulada. Direita: detalhe do gráfico da esquerda evidenciando as duas fases de crescimento da polianilina.

As seções seguintes mostram a caracterização destes compósitos com o principal objetivo de elucidar a forma como a qual a polianilina cresce e ocupa os poros do hidrogel, uma vez que esta forma de distribuição tem papel fundamental no sucesso da aplicação deste novo material em sistemas de liberação controlada eletroquimicamente.

4.3.2 - Caracterização espectroscópica / microscópica de redes condutoras semiinterpenetrantes de polianilina / poliacrilamida: Espectroscopia / Microscopia Raman

A despeito da mudança visual que o hidrogel sofre durante a eletropolimerização da anilina e do voltamograma indicando a eletroatividade do material formado, é indiscutível a necessidade de uma comprovação direta da presença da polianilina neste compósito, e tal comprovação foi obtida através de espectros Raman Ressonante (RR) do compósito. Neste ponto é importante relembrar a síntese do compósito, onde a eletropolimerização é realizada a partir de um fio de platina posicionado no centro do hidrogel e que a coloração escura, devido à presença do polímero condutor (proposição inicial a ser confirmada) cresce radialmente do centro (fio de platina) para a periferia. A Figura 44 mostra o espectro RR obtido no centro do compósito após 120 minutos de 
eletropolimerização. $\mathrm{O}$ espectro confirma a presença da polianilina, e é muito similar aos da polianilina obtida em outras condições ${ }^{15}$.

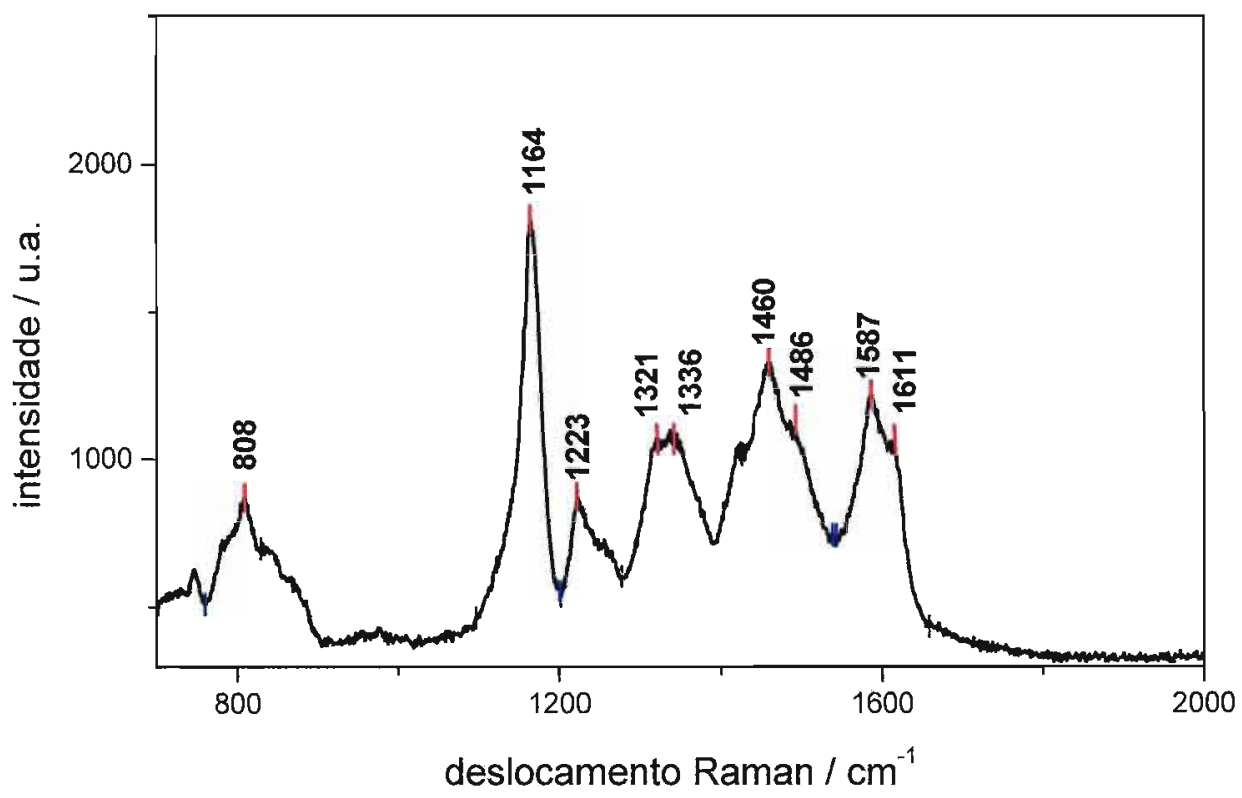

Figura 44 - Espectro Raman da região central do compósito após 120 min de eletropolimerização. Não foi realizada correção na linha base nem suavização do espectro.

As atribuições podem ser vistas na tabela 11 e observando as intensidades relativas (qualitativamente) das bandas na região de freqüências de 1100 a $1700 \mathrm{~cm}^{-1}$ pode-se dizer que o polímero está no seu estado esmeraldina base. O espectro Raman da polianilina dopada primariamente, ou seja, protonada apresentaria as bandas em $\sim 1320 / 1330 \mathrm{~cm}^{-1}$ com uma intensidade comparável a da banda em $1160 \mathrm{~cm}^{-1}$ e maior do que a banda referente ao estiramento $\mathrm{C}=\mathrm{N}$ do anel quinônico ${ }^{15}$, e na forma básica, o espectro mostraria uma menor intensidade relativa das bandas do estiramento $v \mathrm{C}-\mathrm{N}^{++}$, portanto, uma simples inspeção do espectro da Figura 44 revela que a polianilina está desdopada, o que é coerente com o tratamento do compósito (repouso em água) antes da realização da espectroscopia. Quanto ao estado de oxidação, como a intensidade relativa das bandas em $\sim 1320 / 1330 \mathrm{~cm}^{-1}$ e $1611 \mathrm{~cm}^{-1}$ é comparável, pode-se dizer que o polímero condutor está num estado intermediário entre a forma esmeraldina e a pernigranilina, já que as espécies responsáveis por estas bandas são anéis semiquinônicos (forma oxidada) e benzênicos (forma reduzida) respectivamente. 
Tabela 11- Atribuição das bandas Raman do espectro da Figura 44.

\begin{tabular}{cc}
\hline Banda & atribuição \\
\hline 808 w & $\beta \mathrm{N}-\mathrm{H}$ fora do plano(B) \\
1164 s & $\beta \mathrm{C}-\mathrm{H}(\mathrm{Q})$ \\
$1223 \mathrm{w}$ & $v \mathrm{C}-\mathrm{N}(\mathrm{B})$ \\
$1321 / 1336$ sh & $v \mathrm{C}-\mathrm{N}^{+}(\mathrm{SQ})$ \\
$1460 \mathrm{~m}$ & $\nu \mathrm{C}=\mathrm{N}(\mathrm{Q})$ \\
$1486 \mathrm{~m}$ & $\beta \mathrm{N}-\mathrm{H}(\mathrm{B})$ \\
$1587 \mathrm{~m}$ & $\nu \mathrm{C}=\mathrm{C}(\mathrm{Q})$ \\
$1611 \mathrm{sh}$ & $\nu \mathrm{C}-\mathrm{C}(\mathrm{B}) 8 \mathrm{a}$
\end{tabular}

As siglas indicam as intensidades relativas das bandas: $\mathrm{s}=$ forte, $\mathrm{sh}=$ ombro, $\mathrm{w}=$ fraca e tipo de de estrutura: $\mathrm{B}=$ anel benzênico, $\mathrm{Q}=$ anel quinônico e $\mathrm{SQ}$ anel semiquinônico.

$\mathrm{Na}$ figura 45 são comparados dois espectros Raman obtidos em pontos distintos do compósito. $\mathrm{O}$ espectro obtido da região central mostrou um maior sinal para as bandas da polianilina (melhor relação sinal/ruído) do que o espectro da região periférica, ou seja, a polianilina cresce do centro para fora do hidrogel num mecanismo em que ocorrem dois processos simultâneos: a expansão das cadeias até atingirem a superfície do hidrogel e a "concentração" das mesmas, primeiramente, em pontos mais internos do compósito, assim se justifica que no ponto central o espectro Raman tenha uma melhor qualidade (mais polianilina).

Neste ponto cabe ressaltar que só foi possível obter espectros que confirmassem a presença da polianilina no hidrogel pelo efeito Raman Ressonante que este polímero condutor apresenta quando irradiado com um laser em $633 \mathrm{~nm}$, isto porque o espectro da poliacrilamida pura ou em regiões contendo pouco polímero condutor apresentou forte fluorescência. Todavia, após correções na linha base e suavização do espectro, foi possível observar as bandas características da poliacrilamida no hidrogel puro, como mostra a Figura 46. As bandas na região entre $1530-1730 \mathrm{~cm}^{-1}$ são originárias do chamado modo vibracional amida $\mathrm{I}$, correspondentes ao estiramento $\mathrm{C}=\mathrm{O}$. Costa et al ${ }^{72,73}$ descrevem três picos nesta região que são devido a três modos diferentes de interação entre as acrilamidas: um é uma ligação de hidrogênio linear entre um átomo de hidrogênio de um grupo $\mathrm{NH}_{2}$ e o átomo de oxigênio de um grupo carbonila de outra molécula; outro é a formação de um dímero com duas ligações de hidrogênio, como ocorre em ácidos carboxílicos; o terceiro modo seria devido a uma amida não 
associada. Já na região de freqüências entre 1380 e $1500 \mathrm{~cm}^{-1}$, tem-se o chamado modo vibracional amida III, onde aparecem bandas relativas ao estiramento $\mathrm{C}-\mathrm{N}$ e à deformação angular do grupo $\mathrm{CH}_{2}{ }^{73}$.

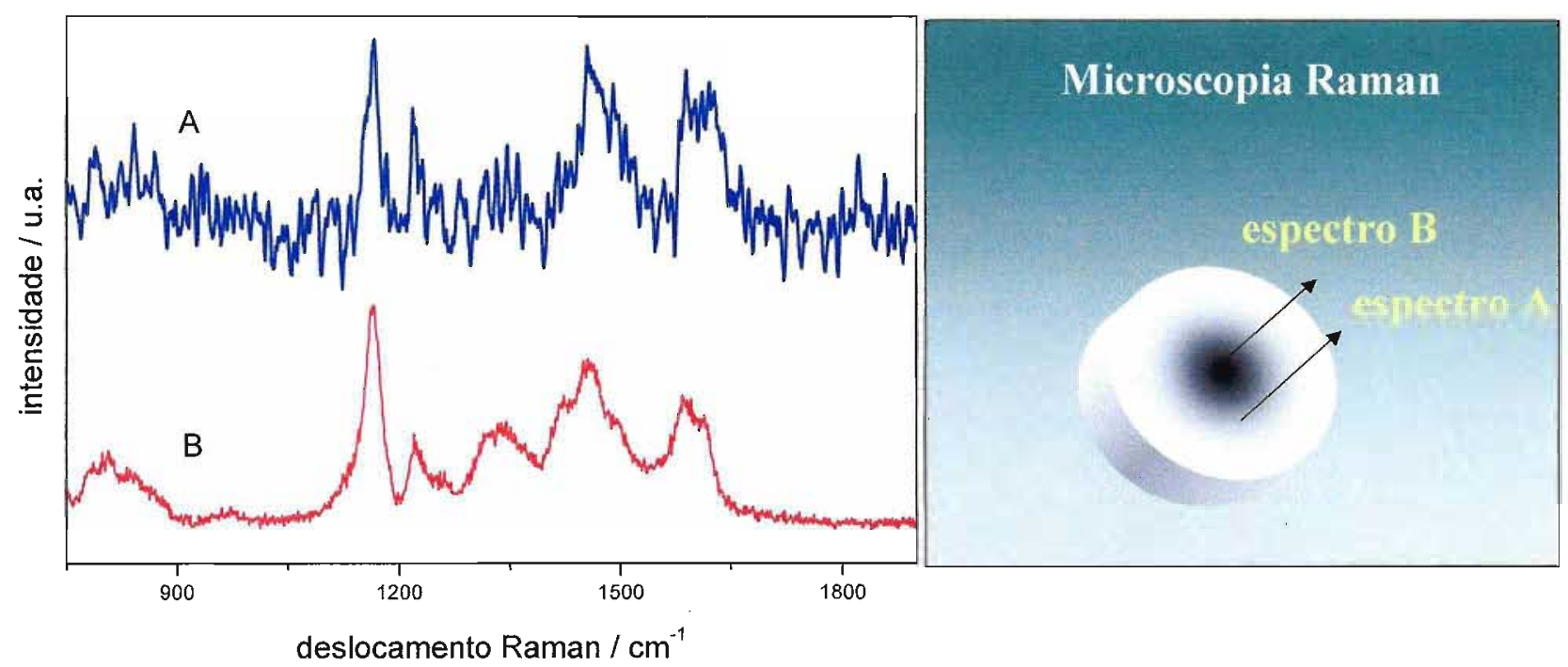

Figura 45 - Esquerda: espectros Raman do compósito em diferentes posições: $\boldsymbol{A}$ fora do centro e $\boldsymbol{B}$ no centro. Ambos mostram a presença de polianilina. Notar a qualidade relativa entre os dois, o espectro $\boldsymbol{A}$ foi corrigido na linha base e suavizado e o espectro $\boldsymbol{B}$ não foi alterado. Direita: esquema mostrando os pontos do compósito dos quais foram obtidos os espectros $\boldsymbol{A}$ e $\boldsymbol{B}$.

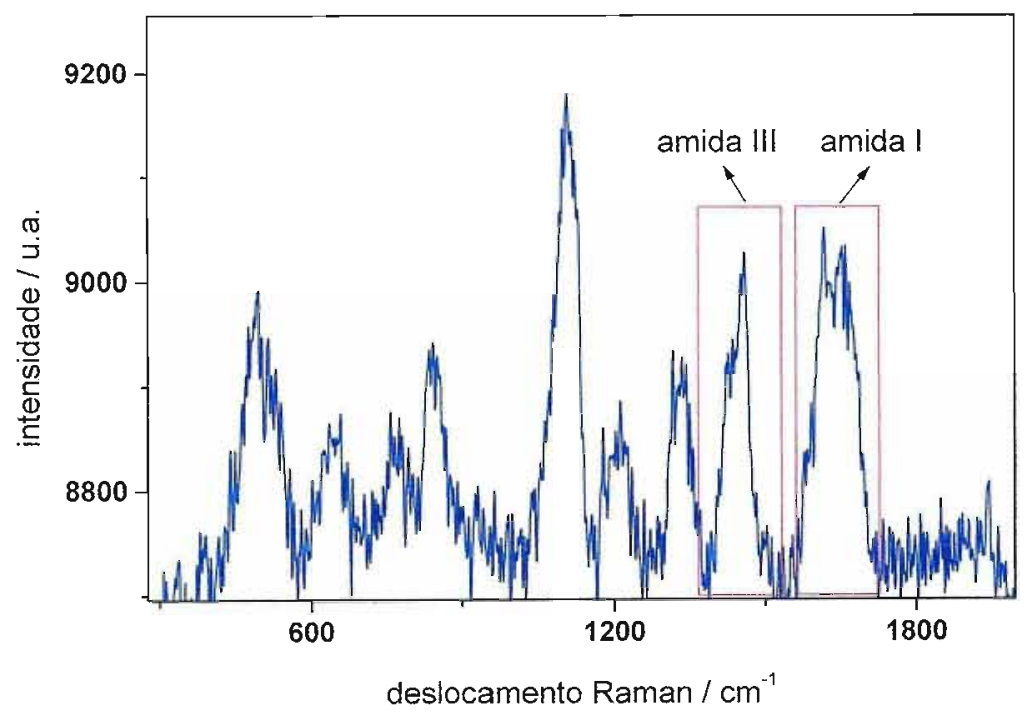

Figura 46 - Espectro Raman da matriz de poliacrilamida. $O$ espectro foi corrigido na linha base e suavizado. Ver texto para detalhes sobre as regiões em destaque. 
Foram obtidos espectros da polianilina, na forma esmeraldina sal, sintetizada livremente (filmes sobre platina) e da polianilina no compósito para comparação e busca de evidências de algum tipo de interação entre os dois polímeros (poliacrilamida e polianilina). A Figura 47 mostra os espectros da polianilina livre (vermelho) e da polianilina incorporada no hidrogel (preto).

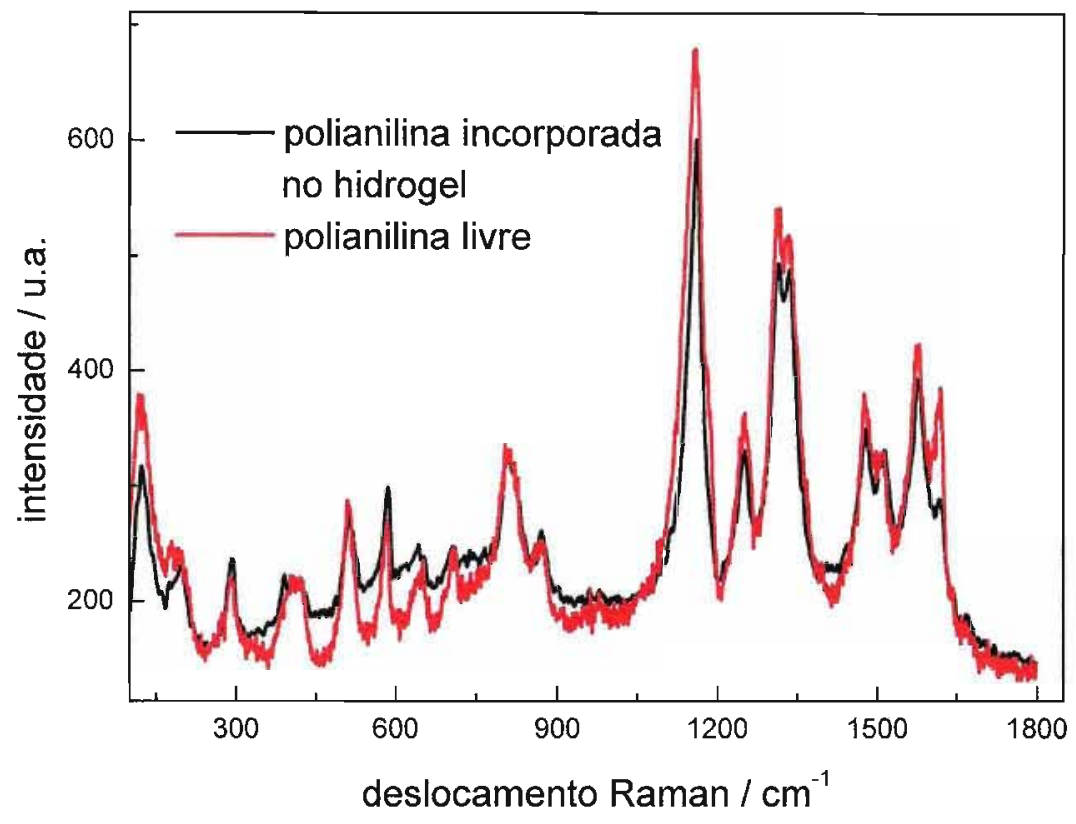

Figura 47 - Espectros da polianilina sintetizada sobre placa de platina (livre) e no interior do hidrogel de poliacrilamida.

Os dois espectros são essencialmente da polianilina no seu estado esmeraldina sal, mas há importantes diferenças espectrais que indicam que a oclusão do polímero condutor modifica seus modos vibracionais, portanto a comparação dos espectros mostra a interação a nível molecular dos componentes do compósito. Por exemplo, na região de $1600 \mathrm{~cm}^{-1}$ há notáveis diferenças nas intensidades relativas das bandas relacionadas aos modos $v \mathrm{C}=\mathrm{C}$ dos anéis benzênicos e quinônicos ${ }^{74}$, mas as diferenças mais interessantes e conclusivas foram as encontradas na banda mais intensa dos espectros, ao redor de $1160 \mathrm{~cm}^{-1}$

A Figura 48 traz a ampliação dos espectros da Figura 47 na região de $1160 \mathrm{~cm}^{-1}$ : a diferença nos dois espectros é um forte indício da presença de interações de van der Waals entre o hidrogênio da ligação $\mathrm{C}-\mathrm{H}$ de anéis benzênicos (e quinônicos) da polianilina e entre o nitrogênio da amina primária e/ou o oxigênio da carbonila das cadeias laterais da poliacrilamida. A banda referente à deformação angular da ligação 
$\mathrm{C}$-H de anéis quinônicos em $\sim 1160 \mathrm{~cm}^{-174}$ é muito mais larga no espectro da polianilina livre do que no da polianilina no compósito; e no compósito, a mesma esta um pouco deslocada para freqüências maiores. Este estreitamento da banda em $1160 \mathrm{~cm}^{-1}$ indica que a oclusão da polianilina, de alguma forma modificou um modo vibracional da ligação $\mathrm{C}-\mathrm{H}$, e esta modificação pode ser a formação de interações intermoleculares como mencionado acima. Além disso, pode se ver mais um modo vibracional (deformação angular), da ligação $\mathrm{C}-\mathrm{H}$ de anéis benzênicos no espectro da polianilina livre em $1185 \mathrm{~cm}^{-1} 74$ que não esta presente no compósito, tal fato é mais um indicio da presença de ligações de hidrogênio que podem limitar os modos vibracionais da ligação $\mathrm{C}-\mathrm{H}$ da polianilina.

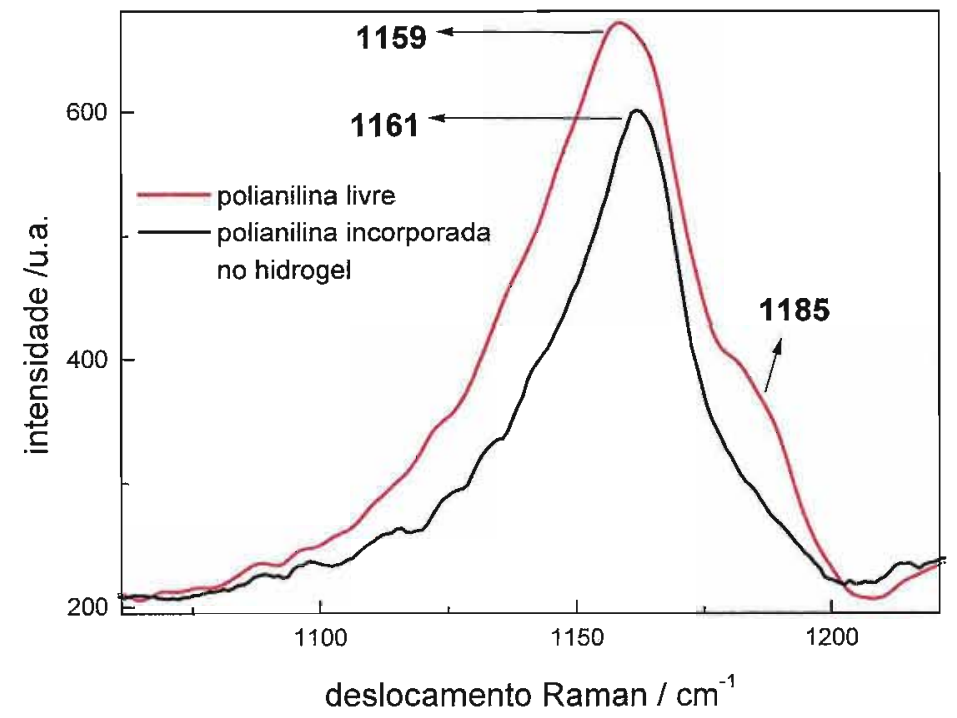

Figura 48 - Detalhe da banda em $\sim 1160 \mathrm{~cm}^{-1}$ dos espectros mostrados na Figura 47.

4.3.3 - Caracterização microscópica de redes condutoras semi-interpenetrantes de polianilina / poliacrilamida: Microscopia de Força Atômica.

A caracterização da superfície do compósito poderia fornecer informações a respeito da distribuição do polímero condutor na matriz se o tempo de eletropolimerização estivesse entre o necessário para a polianilina alcançar a superfície mas não recobri-la totalmente. De fato, um tempo de eletropolimerização de $2 \mathrm{~h}$ para um hidrogel de aproximadamente $0,1 \mathrm{~cm}^{3}$ gerou um compósito com uma superfície diferente daquela vista na matriz pura (como será mostrado a seguir), porém, nitidamente sem que houvesse total recobrimento pelo polímero condutor. 
A Figura 49 traz imagens da superfície do hidrogel puro obtidas com uma varredura de $10 \times 10 \mu \mathrm{m}$. Nas duas imagens é clara a forte interação da ponta com a amostra. De fato a ponta "penteia" a superfície do hidrogel, deixando as marcas da sua varredura. Também pode ser observado nas duas imagens uma fronteira entre duas regiões com comportamentos diferentes, tanto topograficamente, quanto em relação ao coeficiente de atrito. Neste ponto cabe ressaltar que o hidrogel é uma estrutura porosa, onde estes poros são na verdade canais preenchidos com água. Poder-se-ia, então, afirmar que esta fronteira seria a borda de um desses canais, porém o diâmetro médio dos poros esperado para este material é da ordem de centenas de nanômetros e não de alguns micrômetros. Portanto, tal comportamento não pode ser explicado, já que não são esperadas estruturas diferentes neste tipo de superfície.

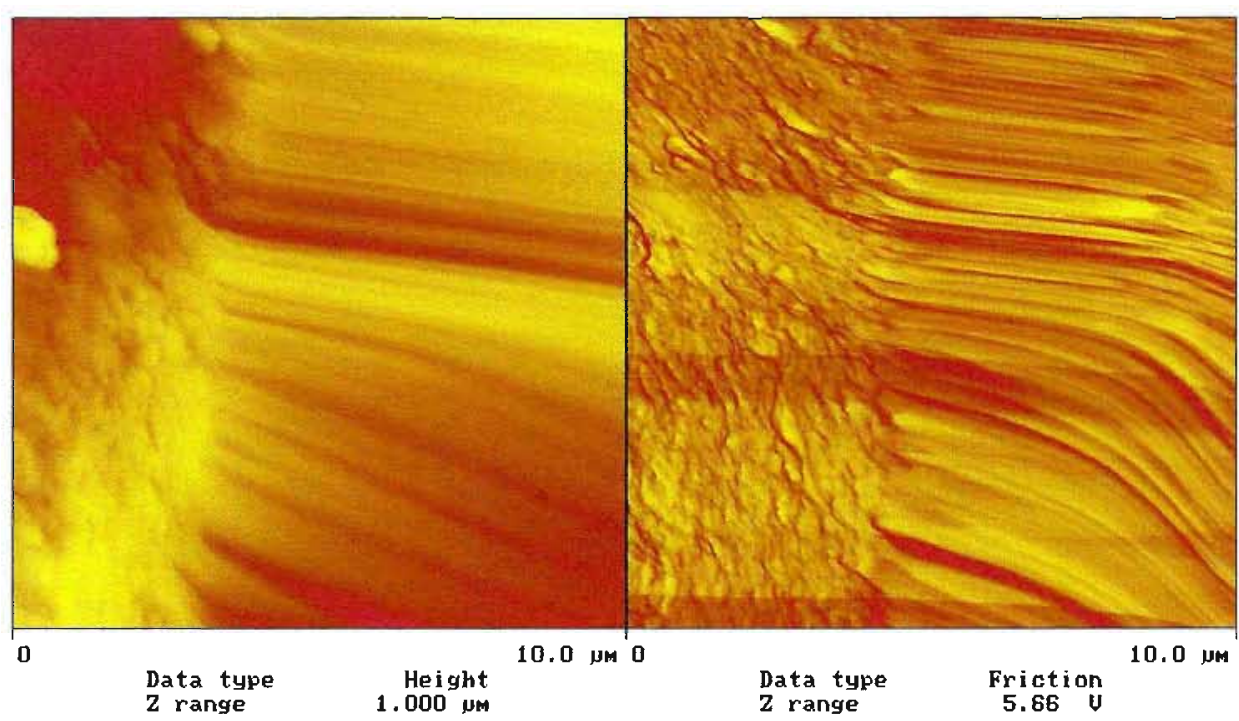

Figura 49 - Imagens do hidrogel. Esquerda: AFM de contato. Direita: LFM.

Na Figura 50 é confirmado que a ponta muda a superfície do hidrogel, uma vez que as imagens seguem o sentido de varredura lenta (ida e volta). Estas imagens têm um tamanho maior que a apresentada na Figura 49, pois o intuito era explorar as duas regiões, porém não se conseguiu mais detalhes. Uma ampliação maior não foi possível devido à irregularidade topográfica da superfície. Comparando a imagem de AFM com a de LFM, tem-se que regiões que se podem ser poros do hidrogel, se mostram como áreas de maior coeficiente de atrito. 

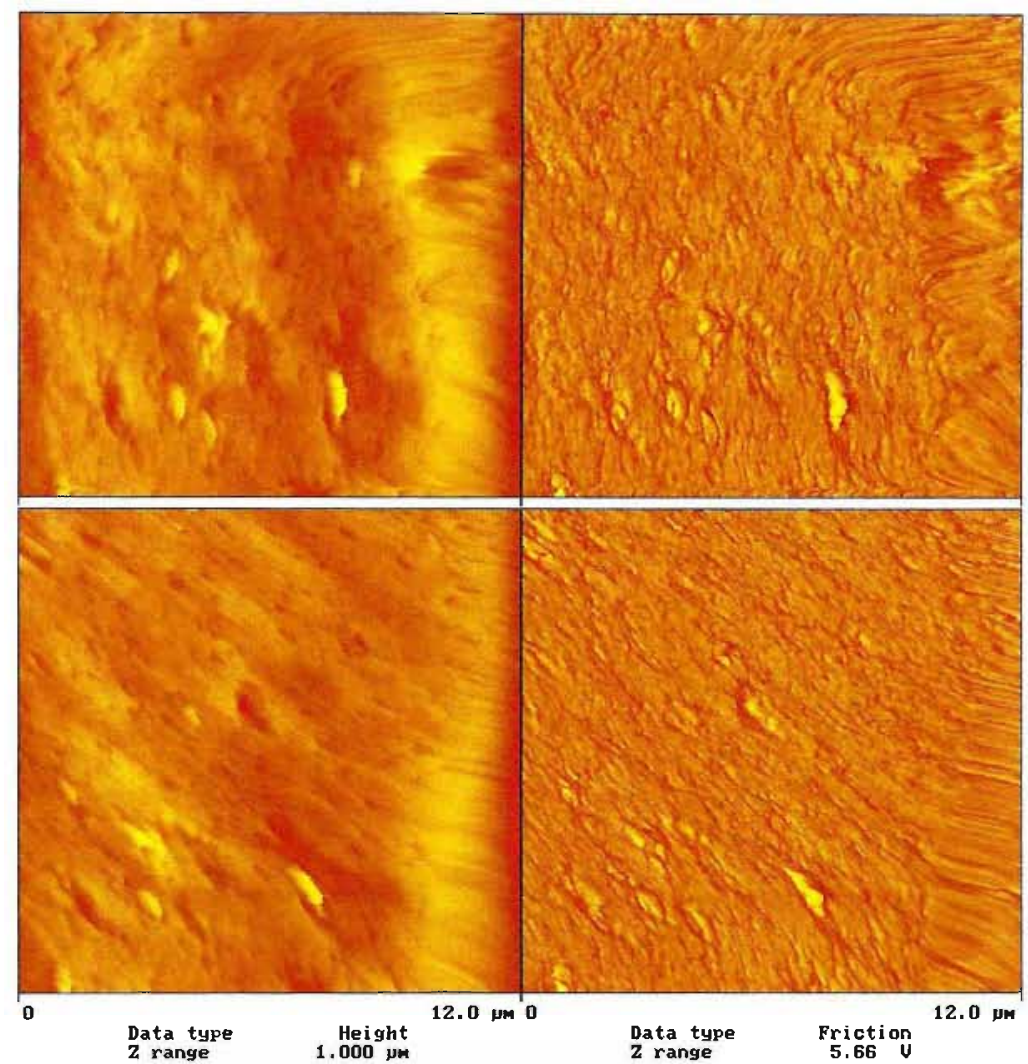

Figura 50 - Imagens do hidrogel. Esquerda: AFM de contato. Direita: LFM. Acima: ida no sentido de varredura lenta. Abaixo: volta no sentido de varredura lenta. Tamanho da varredura: $12 \times 12 \mu \mathrm{m}$.

Na Figura 51 tem-se a imagem de AFM de contato intermitente do compósito. A estrutura em destaque pode representar o polímero condutor atingindo a superfície do hidrogel e formando bordas. A análise desta estrutura forneceu as medidas do tamanho de duas estruturas semelhantes, as quais se mostraram curiosamente com o mesmo tamanho (horizontal) de $295 \mathrm{~nm}$, estes valores estão de acordo com o tamanho médio esperado para os poros desta matriz. A Figura 51 mostra um número de poros muito superior ao que pode ser visto na imagem do hidrogel puro apresentada na Figura 52, ou seja, a superfície irregular e sensível impede a visualização de todos os poros presentes; o compósito, por sua vez (devido à presença da polianilina), apresenta uma resistência mecânica maior e os poros agora são estruturas mais rígidas com bordas que podem ser mais facilmente visualizadas por esta técnica. 


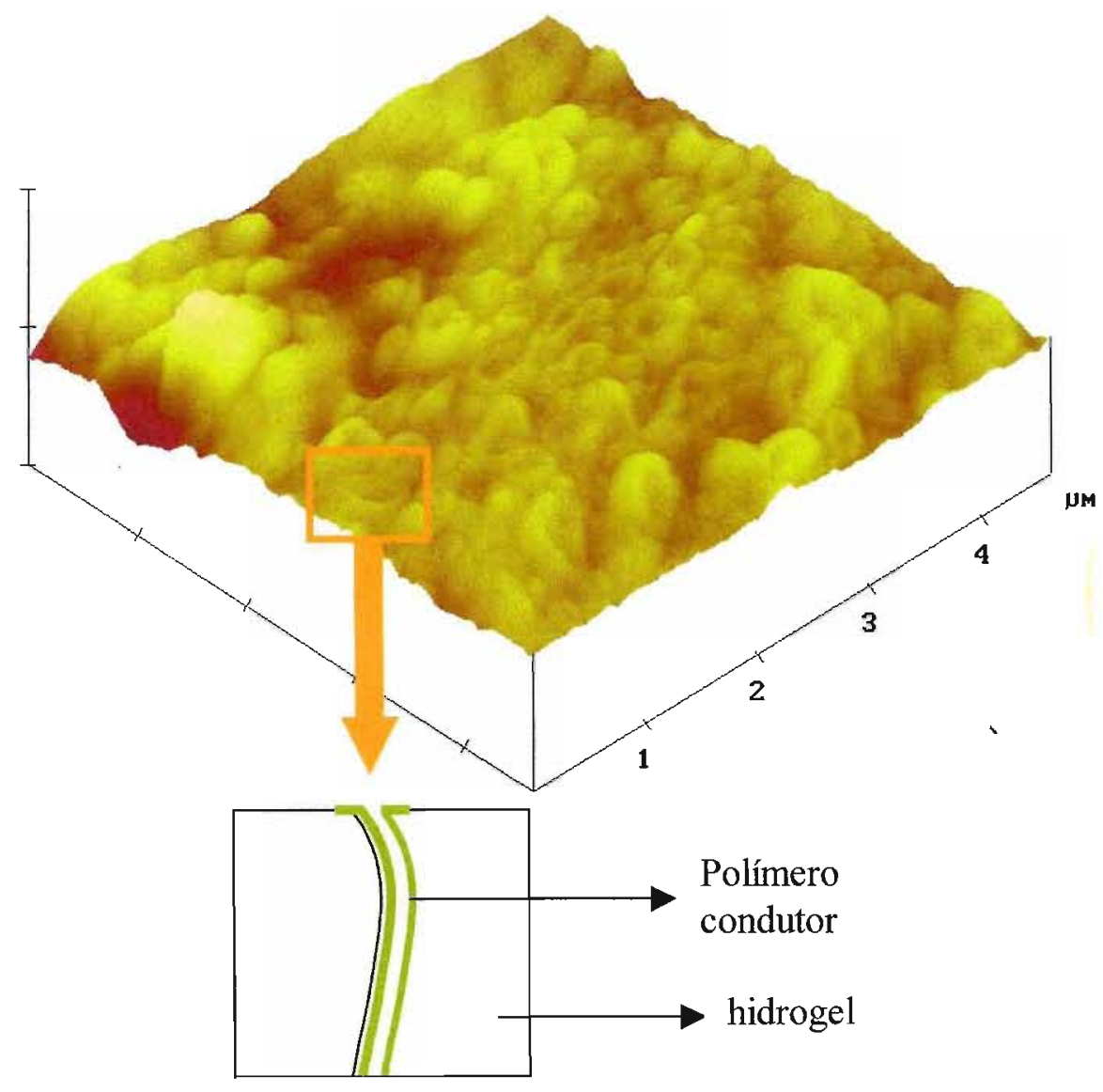

Figura 51 - Imagem de AFM de contato intermitente do compósito. A estrutura em destaque pode representar o polímero condutor atingindo a superfície do hidrogel e formando bordas como representado no esquema.

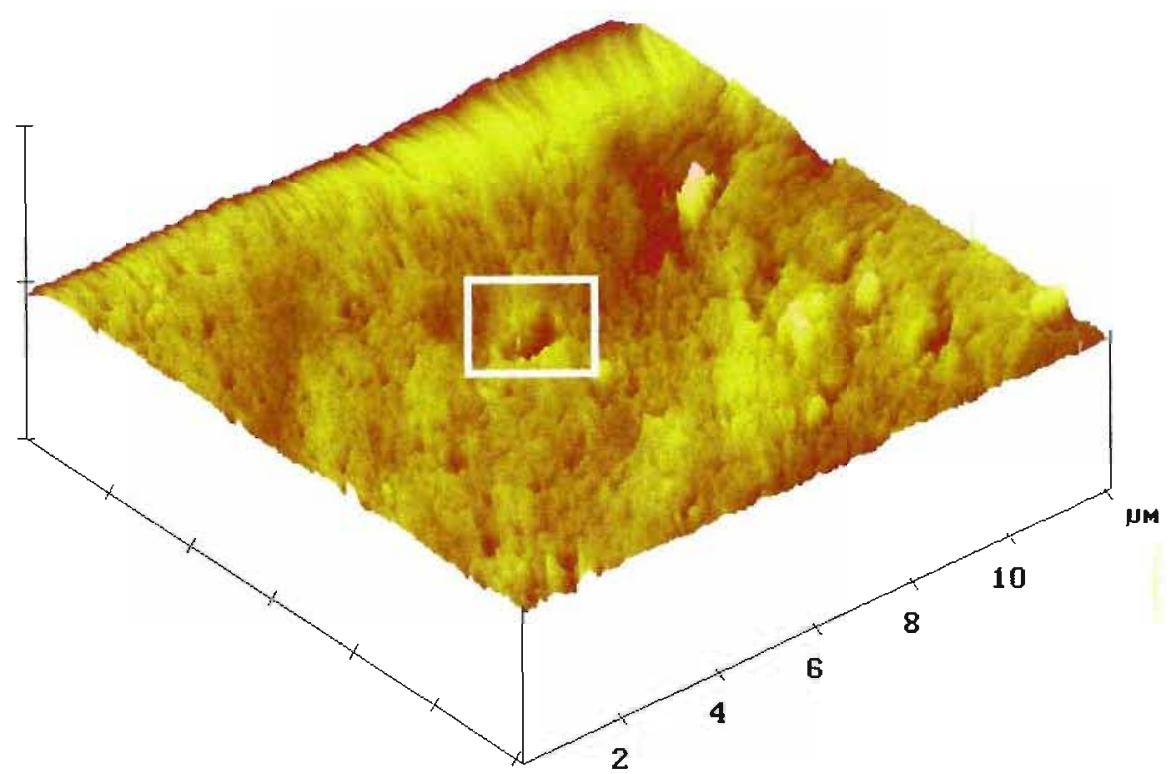

Figura 52 - Imagem de AFM de contato do hidrogel. Em destaque uma estrutura que pode ser um poro da matriz. 
É importante destacar que a microscopia de força atômica, tal como pode ser utilizada, só permitiu a obtenção de imagens do compósito seco, ou seja, embora o tamanho de poro observado na imagem tenha um valor próximo ao relatado na literatura $^{75}$, é preciso cuidado em qualquer comparação, pois os dados da literatura se referem ao tamanho de poro (obtido por técnicas variadas) do hidrogel intumescido, o que deve diferir muito do tamanho de poro do hidrogel no seu estado relaxado (seco). Porém as imagens aqui apresentadas são de grande avalia na caracterização deste novo material. A seguir será mostrado um modo relativo de se determinar o tamanho de poros dos hidrogéis intumescidos (apêndice), parâmetro este fundamental na otimização do sistema quanto ao controle eletroquímico da liberação.

As imagens apresentadas nas Figuras 49 - 52 foram obtidas das superfícies dos hidrogéis e compósitos. Já as Figuras 53 e 54, mostram imagens de AFM de contato obtidas de cortes transversais do compósito seco; estas imagens mostram, em três tamanhos de varredura diferentes, a estrutura porosa da rede, mantida mesmo após a inclusão da polianilina e a distribuição da mesma em camadas formadas por aglomerados de formas variadas (aproximadamente globulares) e de tamanhos variando de 100 a $500 \mathrm{~nm}$ aproximadamente. A Figura 54 é particularmente interessante, pois mostra a mesma imagem em duas escalas de altura diferentes: à esquerda tem-se com maiores detalhes o que seria a borda de um poro e à direita é mostrado mais detalhes do interior do canal.
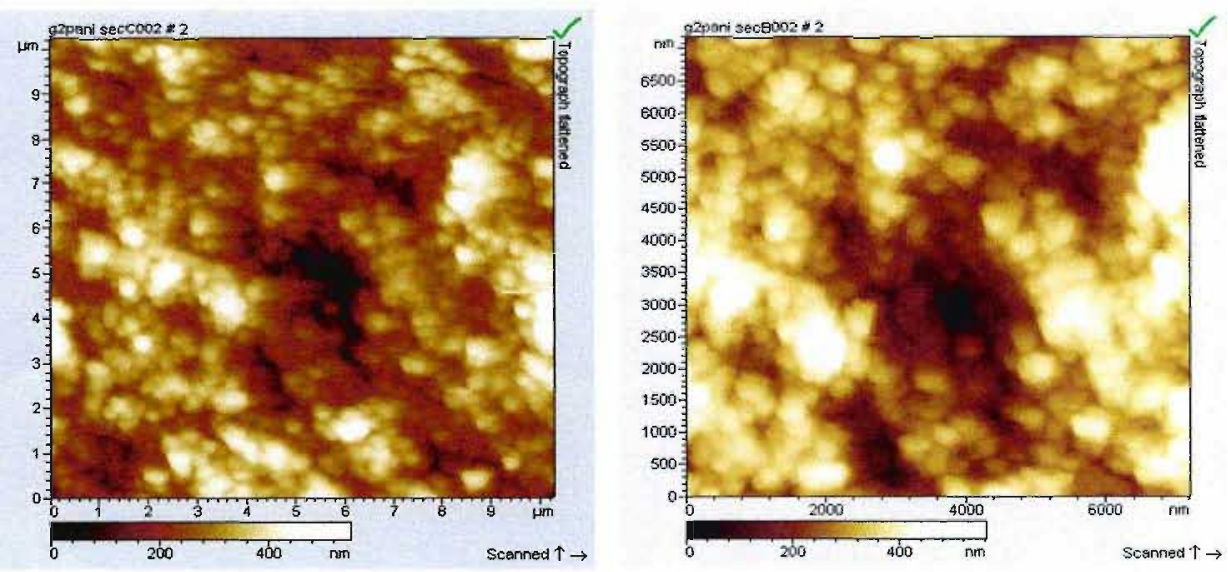

Figura 53 - Imagens de AFM de contado obtidas de corte transversal do compósito. Esquerda: tamanho da varredura: $10 \times 10 \mu \mathrm{m}$. Direita: tamanho da varedura: $7 \times 7 \mu \mathrm{m}$. 

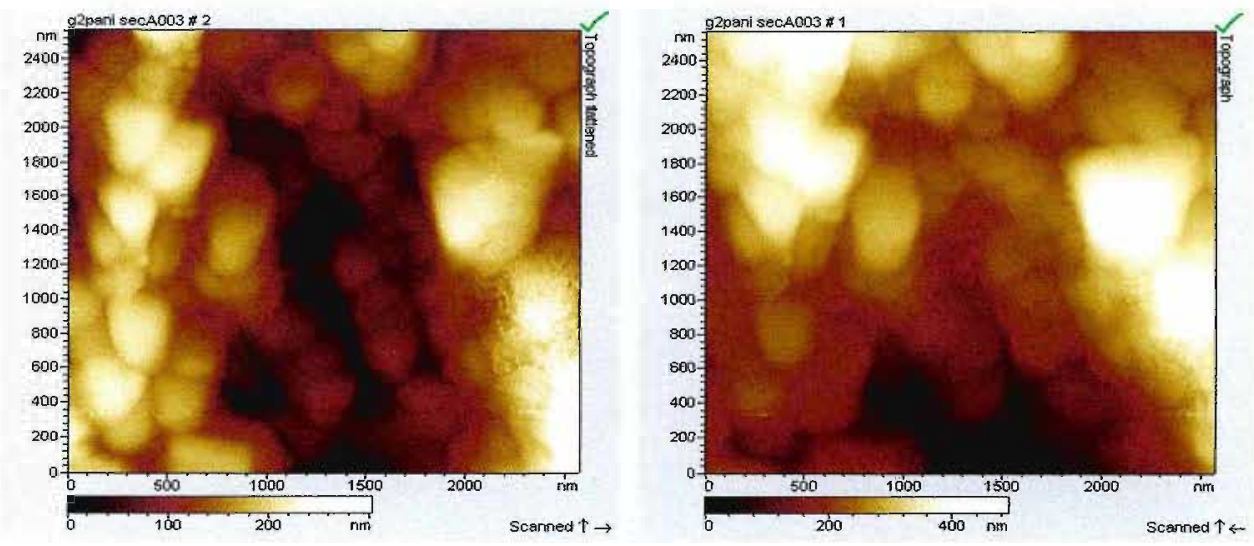

Figura 54 - Imagens de AFM de contado obtidas de corte transversal do compósito. Detalhe de um poro da estrutura em diferentes escalas de altura.

\subsection{4 - Distribuição do polímero condutor no interior da matriz de hidrogel}

Os dados da microscopia Raman e de AFM apresentados nas duas seções anteriores permitiram propor o mecanismo de crescimento para as cadeias de polímero condutor dentro da matriz de poliacrilamida apresentado na Figura 55: sendo os canais do hidrogel formados por cadeias de poliacrilamida, suas paredes contém grupos $-\mathrm{NH}_{2}$ e -CO livres que, por ligações de hidrogênio, podem interagir com as cadeias de polianilina, fazendo com que o polímero condutor cresça paralelamente às paredes do canal. Uma vez que estas estejam recobertas, há o crescimento do polímero condutor na direção perpendicular ao canal e a velocidade de crescimento diminui com a distância do contato elétrico. As estruturas de borda vistas nas imagens de AFM e que aqui fazem parte do modelo proposto, podem ou não aparecer na superfície do compósito de acordo com a quantidade relativa do polímero condutor: assim para um compósito com um volume de $\sim 0,1 \mathrm{~cm}^{3}$ e duas horas de eletropolimerização a $0,75 \mathrm{~V}$, estas estruturas podem ser vistas. A microscopia Raman por sua vez comprova as interações intermoleculares entre os dois polímeros e a distribuição da polianilina ao longo do poro da poliacrilamida como já foi demonstrado.

O conhecimento da forma como o polímero condutor cresce e ocupa os canais do hidrogel é de fundamental importância para a compreensão e otimização destes compósitos como sistemas para liberação controlada de fármacos, uma vez que sua distribuição será refletida na difusão das drogas incorporadas na matriz isolante. $O$ mecanismo de crescimento da polianilina no hidrogel, proposto nesta seção, mantém válida a idéia inicial dos sistemas da Geração II (ver Figura 40), pois do modo como é 
sintetizada a rede condutora semi-interpenetrante, a polianilina cresce de forma a revestir as paredes internas dos poros da poliacrilamida deixando ainda espaço livre para a incorporação de moléculas de interesse.

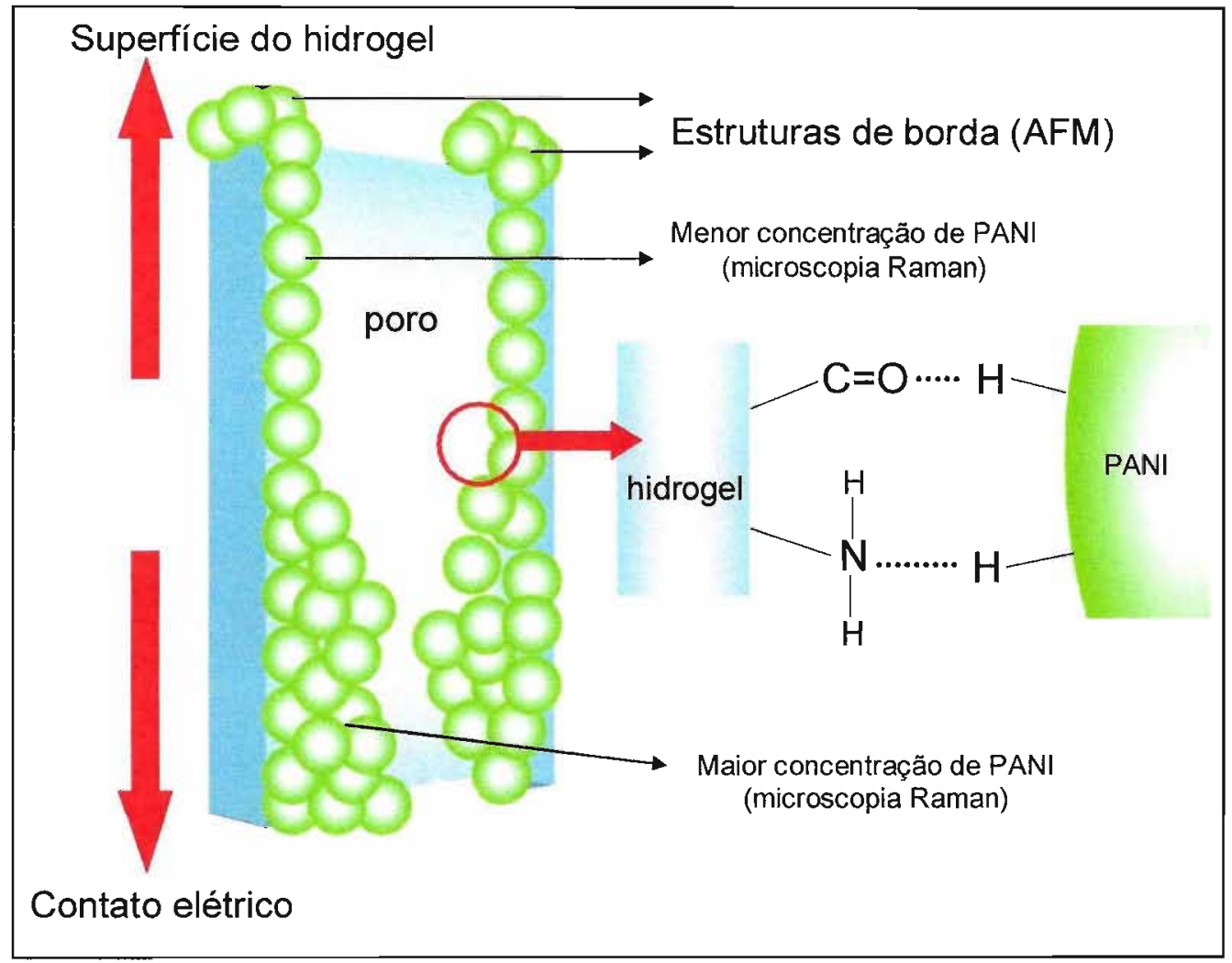

Figura 55 - Mecanismo proposto para o crescimento de polianilina em matriz de poliacrilamida. Tempo de eletropolimerização: $2 \mathrm{~h}$. Volume do hidrogel intumescido: $\sim 0,1 \mathrm{~cm}^{3}$.

4.3.5 - Síntese e estudo de hidrogéis de poliacrilamida com diferentes tamanhos de poro

Partindo da proposta inicial de funcionamento de sistemas da Geração II, o tamanho de poro da matriz de poliacrilamida intumescida foi um parâmetro central no desenvolvimento desta tese e será muito utilizado nas discussões a seguir. Assim, na otimização destes sistemas quanto ao controle eletroquímico da liberação de moléculasmodelo (como será mostrado na seção 4.3.7.1.3) utilizou-se hidrogéis de poliacrilamida com diferentes caractrísticas físicas, e em última instância, com diferentes porosidades ou tamanhos de poro. Para se sintetizar hidrogéis de poliacrilamida com diferentes tamanhos de poro $(\xi)$, variou-se a quantidade relativa do monômero principal (acrilamida) e do agente promotor de ligações cruzadas (MBA), mantendo-se constantes todos os outros parâmetros da síntese. Para se determinar o tamanho de poro de cada um 
dos onze hidrogéis sintetizados foi aplicada a Teoria de Equilíbrio de Intumescimento de Peppas e Merril $^{76}$ com algumas simplificações e aproximações. Desta teoria provém, fundamentalmente, parâmetros relacionados à rede tridimencional dos hidrogéis como a densidade de ligações cruzadas e a razão de intumescimento e a partir deles pode se obter valores para o tamanho médio de poro de cada estrutura. Na Figura 56 são apresentados apenas os resultados finais de tamanho de poro, porém uma rica e detalhada descrição do método e dos outros parâmetros obtidos através da Teoria de Peppas e Merril é esclarecedora e pode ser vista no apêndice desta tese.

Como mencionado no parágrafo anterior, o modelo foi aplicado com algumas aproximações e os valores absolutos de tamanho de poro encontrados carregam estas aproximações (mais detalhes no apêndice) e chegam a diferir até uma ordem de grandeza do esperado (vide apêndice). Porém os resultados podem ser expressos em termos relativos e mesmo assim revelar informações importantes na escolha de hidrogéis de poliacrilamida com tamanho de poro efetivamente diferentes, por esta razão na Figura 56 aparecem valores relativos de tamanho de poro e no apêndice pode se ver a mesma figura com os valores absolutos obtidos da Teoria.

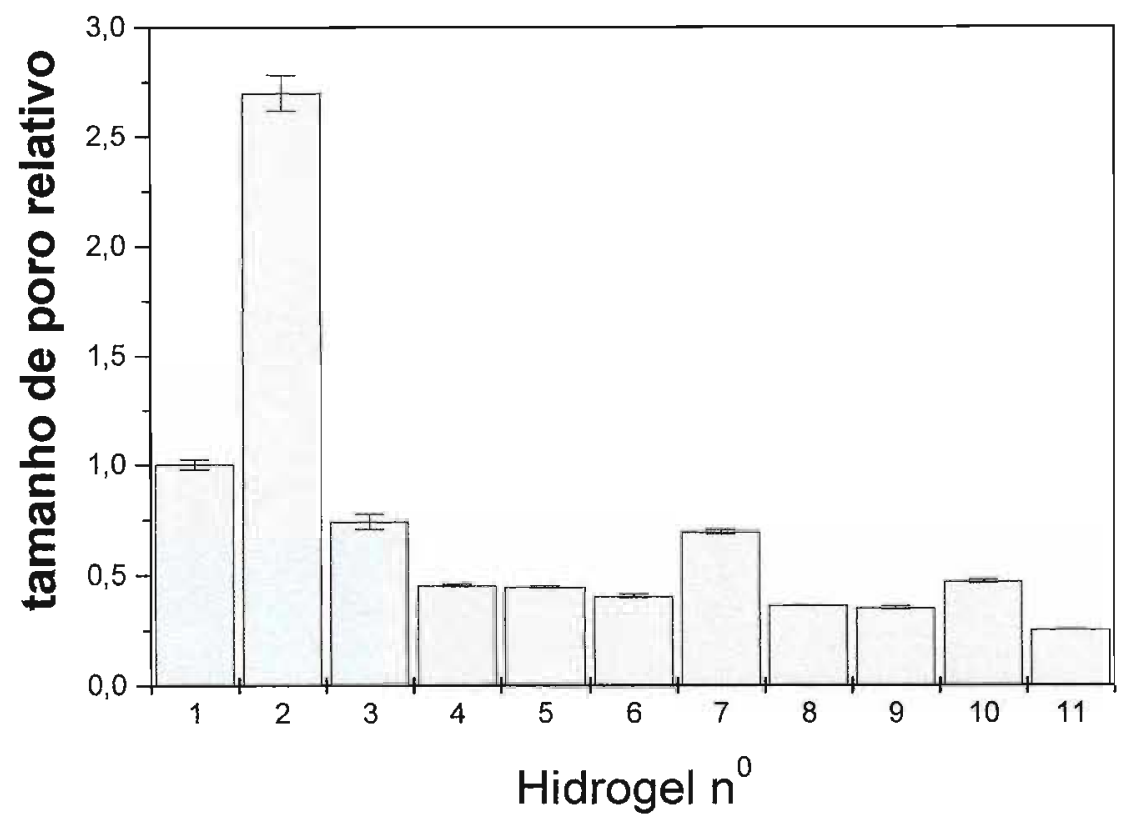

Figura 56 - Tamanho de poro relativo para os 11 hidrogéis de poliacrilamida sintetizados com diferentes relações AAM/MBA (detalhes na parte experimental). Cada hidrogel foi nomeado simplesmente com um número, e o hidrogel 1 foi escolhido como tendo o tamanho de poro de referência. As barras de erro são relativas à dispersão dos valores encontrados em três medidas. Mais detalhes ver apêndice . 
Das onze formulações testadas a fim de se gerar hidrogéis de poliacrilamida com diferentes tamanhos de poros, escolheu-se três para se prosseguir com a caracterização e com os testes de liberação controlada. Portanto com base na Figura 56, os hidrogéis 1, 2 e 11, que apresentaram maiores diferenças entre si nos tamanhos de poros relativos, foram melhor caracterizados por microscopia eletrônica de varredura (próxima seção) e por fim utilizados na parametrização da liberação controlada eletroquimicamente.

4.3.6 - Caracterização microscópica de redes condutoras semi-interpenetrantes de polianilina / poliacrilamida: Microscopia Eletrônica de Varredura

A obtenção de imagens por microscopia eletrônica de varredura teve como objetivos a caracterização das superfícies dos hidrogéis e dos compósitos formadas na polimerização e das superfícies destes geradas por cortes longitudinais e transversais.

\subsubsection{1 - Imagens dos hidrogéis}

Uma vez que a aplicação da teoria de equilíbrio de intumescimento, apresentada na seção anterior não forneceu valores absolutos confiáveis para o tamanho de poro dos diversos hidrogéis sintetizados, obteve-se imagens de MEV no intuito de obter de forma direta o tamanho de poros dos hidrogéis de poliacrilamida.

A maior dificuldade na utilização da técnica é a preparação das amostras, principalmente quando estas contêm grande quantidade de água. Na tentativa de se observar a estrutura porosa dos hidrogéis com o mínimo de alteração devido à perda de água, se utilizou o modo de baixo vácuo do microscópio e um processo de liofilização "in situ", no qual primeiramente a amostra era posicionada no porta-amostra, congelada em nitrogênio líquido e submetida à pressão de $70 \mathrm{~Pa}$ na câmara de amostras do microscópio. A Figura 57 mostra as primeiras imagens obtidas da superfície de um hidrogel 2 seguindo este procedimento: a imagem A é da superfície congelada após permanecer 15 minutos a $70 \mathrm{~Pa}$, a imagem também foi obtida a $\sim 70 \mathrm{~Pa}$. Como melhores imagens (com maior resolução e contraste) em MEV são obtidas trabalhando-se com menores pressões, a imagem B, para a mesma superfície foi obtida com uma pressão de $\sim 10 \mathrm{~Pa}$ e a imagem $\mathrm{C}$ é uma ampliação da imagem $\mathrm{B}$, mostrando claramente a melhor qualidade da imagem e também detalhes de estruturas circulares poderiam ser as aberturas dos poros da rede tridimensional, porém segundo a literatura ${ }^{77}$ os maiores 
poros encontrados em estruturas reticuladas de poliacrilamida são da ordem de $0,5 \mu \mathrm{m}, \mathrm{e}$ em particular, para o hidrogel 2 sintetizado, esperava-se ${ }^{75,77}$ tamanhos de poros entre 5$20 \mathrm{~nm}$, assim as estruturas vistas nas imagens da Figura 57 podem ser atribuídas ao colapso dos poros menores ocorrido durante o processo de congelamento e secagem em baixo vácuo $(\sim 70 \mathrm{~Pa})$.

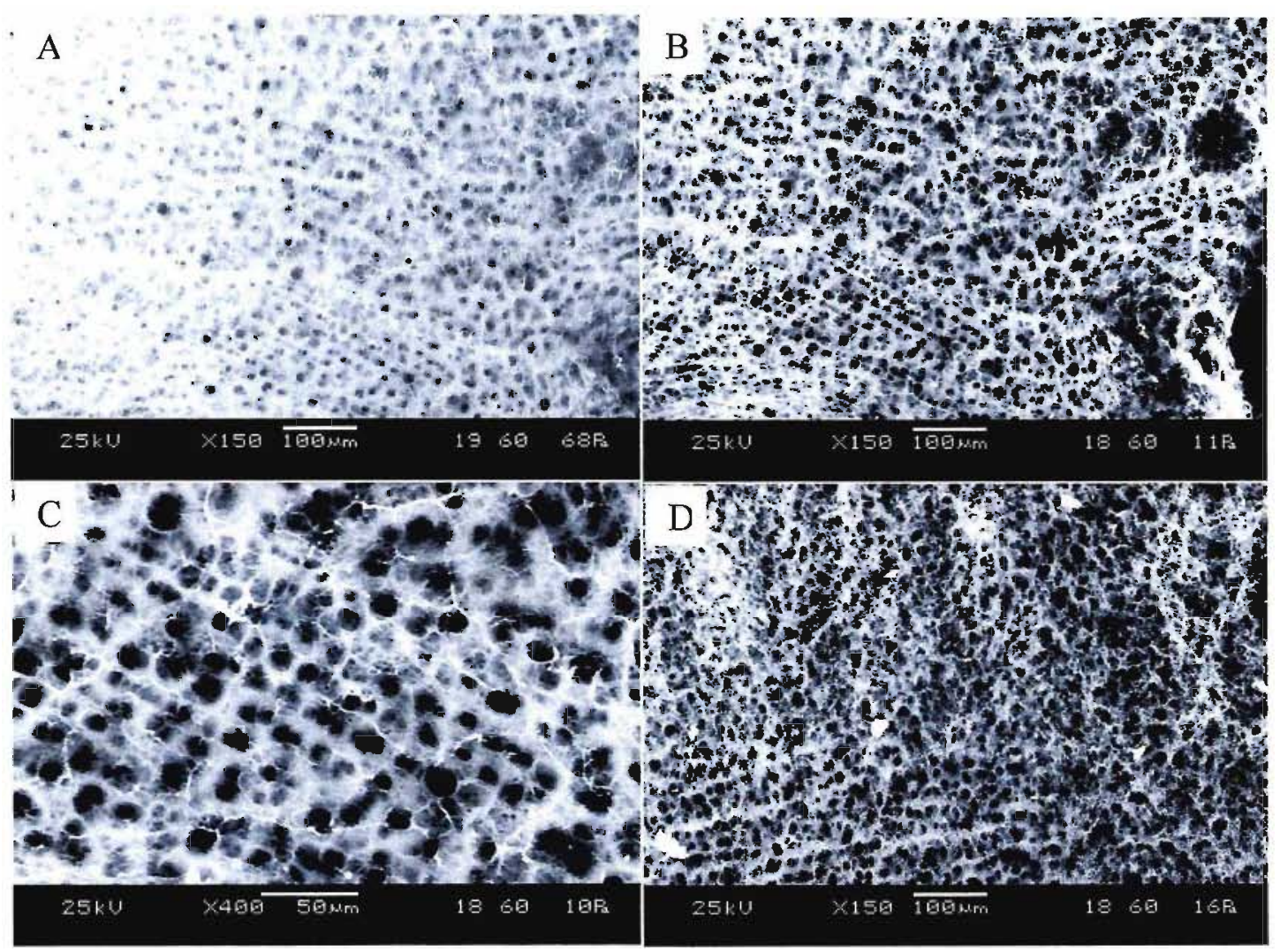

Figura 57 - Imagens de $\mathrm{MEV}$ da superfície do hidrogel 2. Imagem A: amostra congelada e depois de 15 minutos a aproximadamente $70 \mathrm{~Pa}$. Imagem $\mathrm{B}$ : obtida com uma pressão de $11 \mathrm{~Pa}$. Imagem $\mathrm{C}$ : ampliação de $\mathrm{B}$ mostrando estruturas semelhantes a

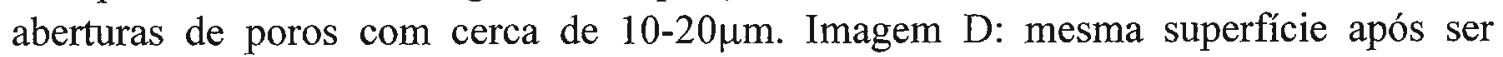
submetida ao alto vácuo do microscópio.

O efeito macroscópico deste colapso quando o hidrogel é seco ao ar ou a temperaturas mais elevadas e sem o prévio congelamento em nitrogênio líquido é a diminuição do volume do hidrogel, uma vez que sem a água que ocupava os espaços vazios da rede, há uma aproximação das cadeias. A intenção de congelar o hidrogel antes de sua secagem em baixo vácuo é promover a liofilização do hidrogel (sublimação da água) e desta forma tentar diminuir o grau de colapso da estrutura, ou seja, analisar uma estrutura o mais parecida possível com aquela utilizada na síntese do compósito. 
Macroscopicamente, o efeito da saída da água através da sublimação parece manter praticamente inalterada a estrutura do hidrogel quanto ao seu tamanho, porém seu aspecto muda de transparente para branco, indicando assim uma mudança na rede tridimensional. Microscopicamente, as imagens revelaram "tamanhos de poros" muito superiores ao esperado, e como já mencionado, estes não seriam os tamanhos de poro presentes no hidrogel intumescido, mas sim o resultado do espaço deixado pela aproximação das cadeias de poliacrilamida após a sublimação da água.

Analisando cuidadosamente a imagem $57 \mathrm{C}$ pode se notar que as paredes de poliacrilamida, que formam os poros gerados pelo colapso da estrutura, não parecem contínuas, podendo elas mesmas ser malhas poliméricas com o tamanho de poro procurado. Como o modo de baixo vácuo do MEV não permite magnificações muito grandes, para se visualizar em detalhe essas regiões da superfície, o hidrogel teria que ser submetido ao modo normal do microscópio (alto vácuo). Para verificar se o alto vácuo causaria um colapso ainda maior da estrutura, o hidrogel foi submetido a baixas pressões por 15 minutos, depois se retornou à condição de baixo vácuo (16Pa) e viu-se que a estrutura mantinha-se a mesma (Figura 57D), assim determinou-se que após a liofilização a baixo vácuo, os hidrogéis poderiam ser analisados no modo normal do MEV.

A Figura 58 traz imagens da superfície do hidrogel 1 obtidas no modo de alto vácuo do MEV. Através da comparação com a Figura 57, pode-se dizer que a superfície do hidrogel 1 é mais "fechada" que a superfície do hidrogel 2, mostrando um maior entrelaçamento das cadeias devido a um maior número de ligações cruzadas presentes, o que está de acordo com a composição das soluções pré-gel do hidrogel 1 e 2 (ver apêndice), uma vez que maiores concentrações de acrilamida e MBA resultam em hidrogéis mais reticulados. As imagens das Figuras 57 e 58 também corroboram (qualitativamente) os dados obtidos através da teoria de equilíbrio de intumescimento e o fato do hidrogel 1 ser mecanicamente mais resistente. De fato, as imagens obtidas no modo de alto vácuo têm melhor qualidade e revelam mais detalhes da estrutura por permitirem maiores magnificações. A Figura 58A é a mais panorâmica da superfície de um hidrogel 1 gerada pela copolimerização dos monômeros. Na Figura 58B pode-se notar uma distribuição de tamanhos de poros de alguns micrometros e a maior magnificação conseguida, mostrada na figura 58C, revela estruturas de aproximadamente $500 \mathrm{~nm}$. Embora estes tamanhos de poros sejam mais próximos do esperado, novamente não pode ser descartada a possibilidade de colapso da estrutura 
durante a preparação da amostra, assim estes dados têm um valor comparativo (relativo), maior do que um valor absoluto. Aqui cabe ressaltar que durante a observação não foi verificada a alteração da estrutura.

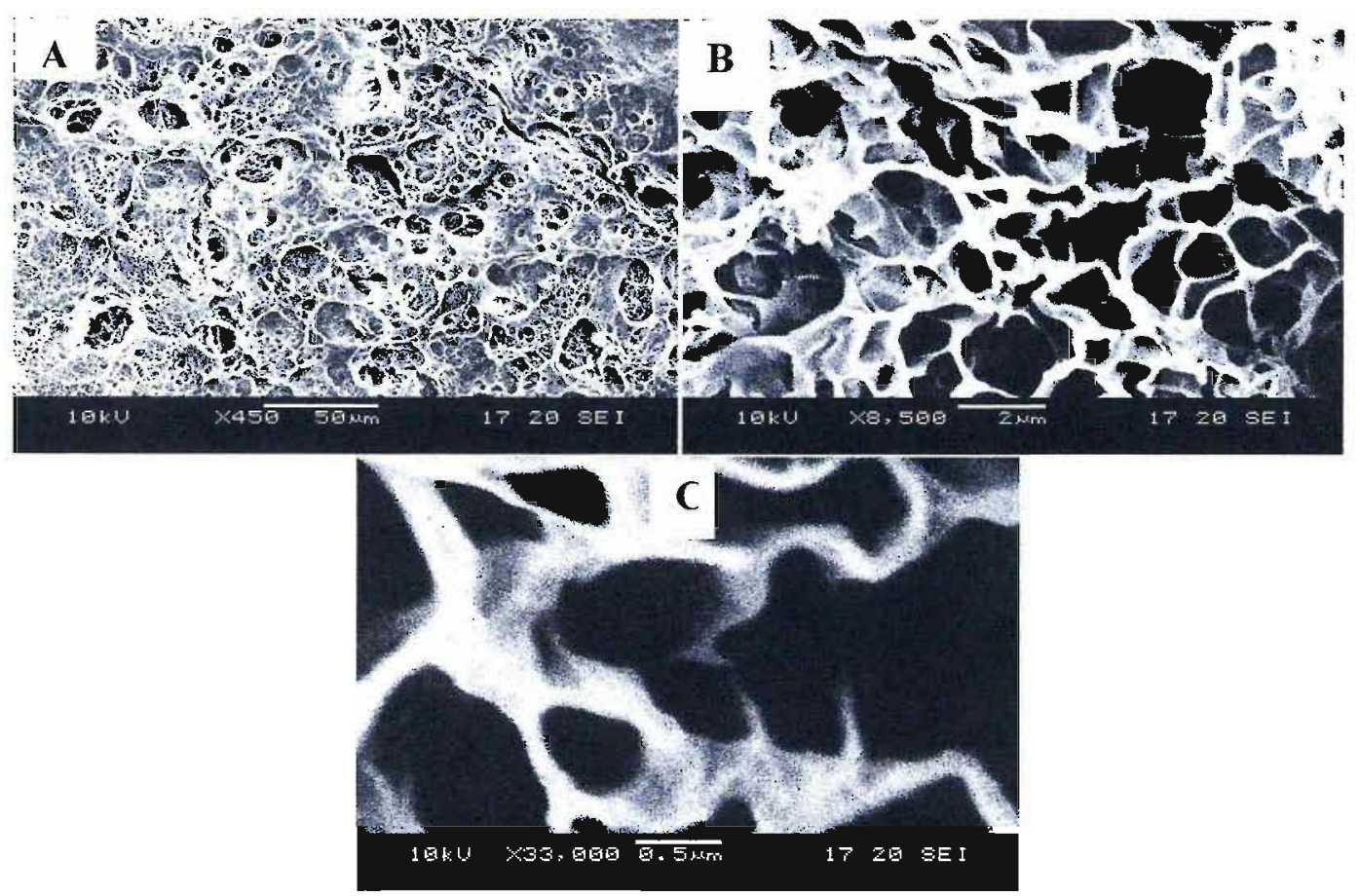

Figura 58. Imagens de MEV (alto vácuo) para a superfície de um hidrogel 1 gerada pela copolimerização dos monômeros. A -Visão mais panorâmica da superfície. B Magnificação de 8500X. C - Magnificação de 33000X.

Imagens do hidrogel 11 são mostradas na Figura 59. A Figura 59A mostra duas superfícies do hidrogel: a superfície gerada pela polimerização e a superfície gerada por um corte longitudinal. As demais imagens (Figura 59B e 59C) são as melhores obtidas com magnificações maiores das superfícies geradas por cortes transversais e longitudinais. Em nenhuma delas foi possível observar os poros da poliacrilamida reticulada, também foi verificado que não houve o colapso da estrutura após a preparação da amostra, uma vez que não há poros maiores nessas superfícies devido à aproximação das cadeias poliméricas. Como esta matriz é a que apresenta o menor tamanho de poro (segundo a teoria de equilíbrio de intumescimento) pode-se dizer que a microscopia eletrônica de varredura não tem resolução suficiente para se observar os poros deste hidrogel, e como se trata de uma rede com uma grande densidade de ligações cruzadas $\left(\sim 5 \mathrm{mmol} . \mathrm{cm}^{-3}\right)$ conclui-se que, diferentemente dos hidrogéis $1 \mathrm{e} 2$, o hidrogel 11 mantém sua estrutura após a liofilização. 

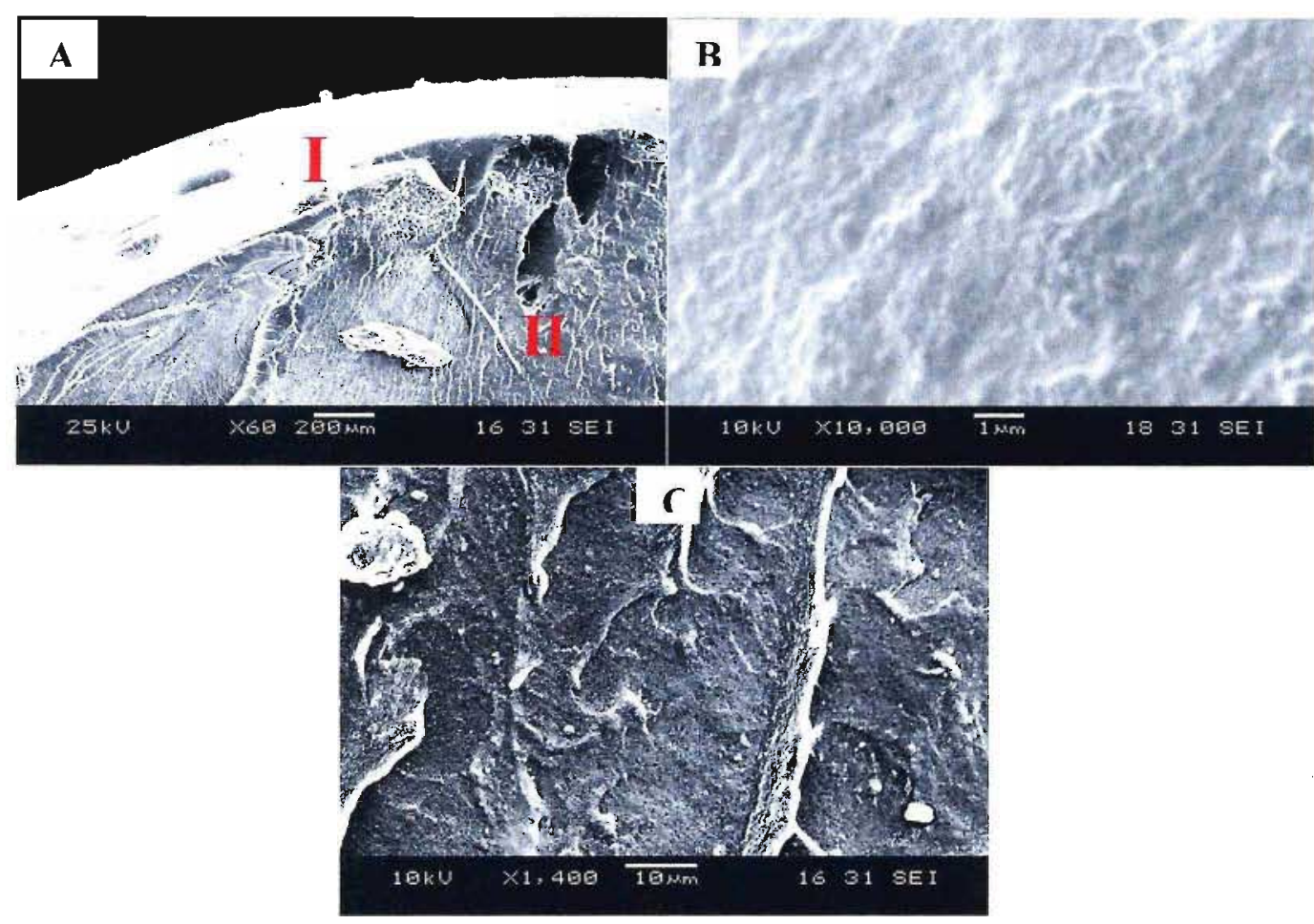

Figura 59. Imagens de MEV (alto vácuo) de um hidrogel 11. A -Visão mais panorâmica da superfície gerada pela copolimerização de acrilamida e MBA (região I) e da superfície gerada por um corte longetidinal (região II). B - Corte longitudinal. C Corte transversal.

\subsubsection{2 - Imagens dos compósitos}

As imagens obtidas para as redes condutoras semi-interpenetrantes forneceram informações a respeito da distribuição da polianilina dentro da matriz de poliacrilamida. A Figura 60 traz a imagem de um corte transversal de um compósito formado pela passagem de 8,5C de carga durante a eletropolimerização de anilina no interior de um hidrogel 2. Macroscopicamente, o compósito tinha a coloração preta, atribuída a presença da polianilina, por quase todo o seu volume. Lembrando que a carga de $8,5 \mathrm{C}$ foi escolhida como ponto final da eletropolimerização já que, visualmente, neste ponto se tinha o hidrogel praticamente todo preenchido com o polímero condutor, pode-se concluir que esta não é uma forma adequada de se controlar o ponto de preenchimento total do hidrogel, uma vez que a imagem 60A mostra que apenas uma fração da matriz de poliacrilamida foi preenchida com polianilina. Esta conclusão vem da nítida distinção morfológica entre o hidrogel e o compósito, ou seja, entre a região do hidrogel onde houve a eletropolimerização (formação do compósito) e a região onde há predominantemente poliacrilamida reticulada. Na primeira, tem-se uma superfície mais 
homogênea e suave e mesmo depois da liofilização, as estruturas porosas devido ao colapso da rede de poliacrilamida não são mais vistas, provavelmente devido ao preenchimento da estrutura com polianilina. As Figuras $60 \mathrm{~B}, \mathrm{C}$ e D são cada uma a ampliação da imagem anterior na região marcada, assim na Figura 60B tem-se um detalhe da região interfacial, mostrando mais claramente a diferença morfológica entre o compósito e o hidrogel. A Figura 60C mostra que nesta interface ainda é possível ver reminiscências da estrutura porosa da poliacrilamida junto com o compósito mais uniforme morfologicamente. Por fim, com a maior magnificação, com a qual ainda se obteve boas imagens (Figura 60D), pode-se ver detalhes do compósito que corroboram o mecanismo proposto para o crescimento da polianilina no interior do hidrogel (Figura 55- seção 4.3.4): a imagem mostra canais com paredes que se assemelham a "escamas", que de acordo com o modelo podem ser interpretados como as paredes dos canais (poros) do hidrogel recobertas com cadeias de polianilina. Sendo estas "escamas" várias camadas de cadeias de polianilina sobrepostas, de acordo com o esquema da Figura 55.

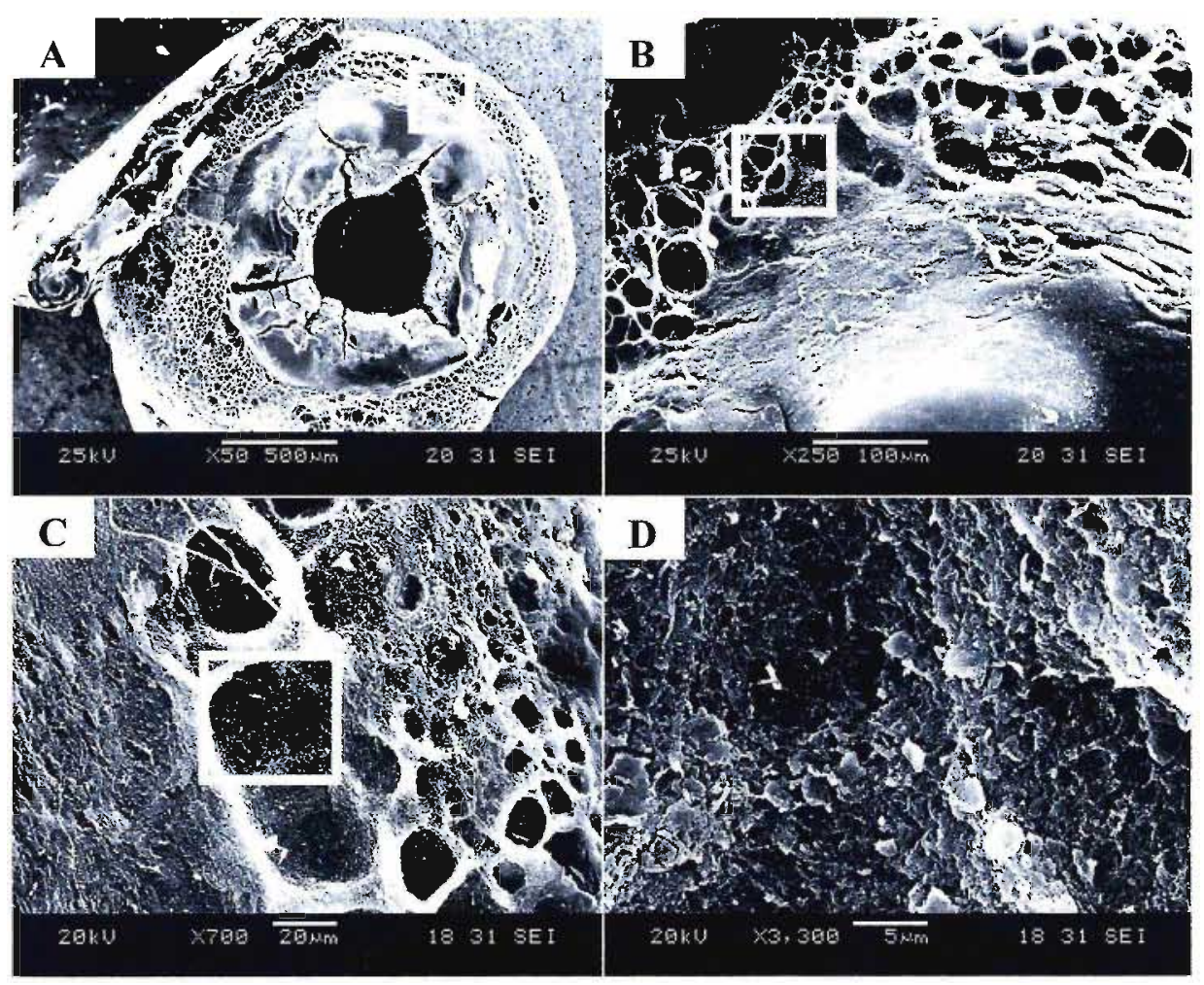

Figura 60 - Imagens de MEV (alto vácuo) para uma rede condutora semi-interpenetrante formada pela eletropolimerização de anilina no interior de um hidrogel 2. A imagem A é da superfície gerada por um corte transversal do compósito, as demais imagens são ampliações da região marcada na imagem anterior. A estrutura que aparece não canto superior esquerdo da figura A é um pedaço de fita de carbono utilizado para promover o contado elétrico entre o filme de ouro sobre a superfície e o porta-amostra e o orifício 
no centro do compósito é o espaço deixado pelo fio de Pt inserido na poliacrilamida para servir de contato elétrico nos experimentos eletroquímicos

Na Figura 61 tem-se imagens de MEV para a superfície de um compósito de polianilina/hidrogel 1 , a carga de eletropolimerização neste caso também foi de $8,5 \mathrm{C}$, mas a fração de hidrogel preenchido com polímero condutor é maior do que a vista para o compósito apresentado na Figura 60, sintetizado a partir de um hidrogel 2 e sob as mesmas condições. Este resultado pode ser interpretado em função do parâmetro que difere estes dois experimentos: a matriz de poliacrilamida. Sendo o hidrogel 1, em comparação com o hidrogel 2, uma rede tridimensional com uma densidade de reticulação maior, e portanto com um menor tamanho de poro, existe menos espaço vazio a ser preenchido pelo polímero condutor. Assim para uma mesma carga de eletropolimerização, ou seja, para uma mesma quantidade de polianilina no compósito, de fato, se esperaria distribuições diferentes do polímero condutor nas diferentes matrizes de poliacrilamida; e os resultados apresentados nas Figuras 60A e $61 \mathrm{~A}$ estão de acordo com o esperado: como há menos espaço livre para a polianilina ocupar dentro do hidrogel 1 (Figura 61), o crescimento do polímero condutor paralelo às paredes dos poros da poliacrilamida é desfavorecido, enquanto que o crescimento de ramificações da polianilina para a periferia da matriz, ocupando todo o volume do compósito é favorecido, fazendo com que uma menor quantidade de polímero condutor seja necessária para ocupar todo o compósito formado a partir do hidrogel 1 do que àquele formado com o hidrogel 2.

Na Figura 61B tem-se uma ampliação da região marcada na Figura 61A e que corresponde a região do compósito contendo predominantemente poliacrilamida. As Figuras $61 \mathrm{C}$ e $61 \mathrm{D}$ são, respectivamente, imagens das superfícies geradas por cortes transversal e longitudinal do compósito (região com poliacrilamida e polianilina), e comparando as duas imagens, pode-se concluir que não há diferença marcante na estrutura do compósito em uma direção, ou seja, os canais do hidrogel estão distribuídos aleatoriamente em todas as direções, e o polímero condutor os preenche indistintamente. 


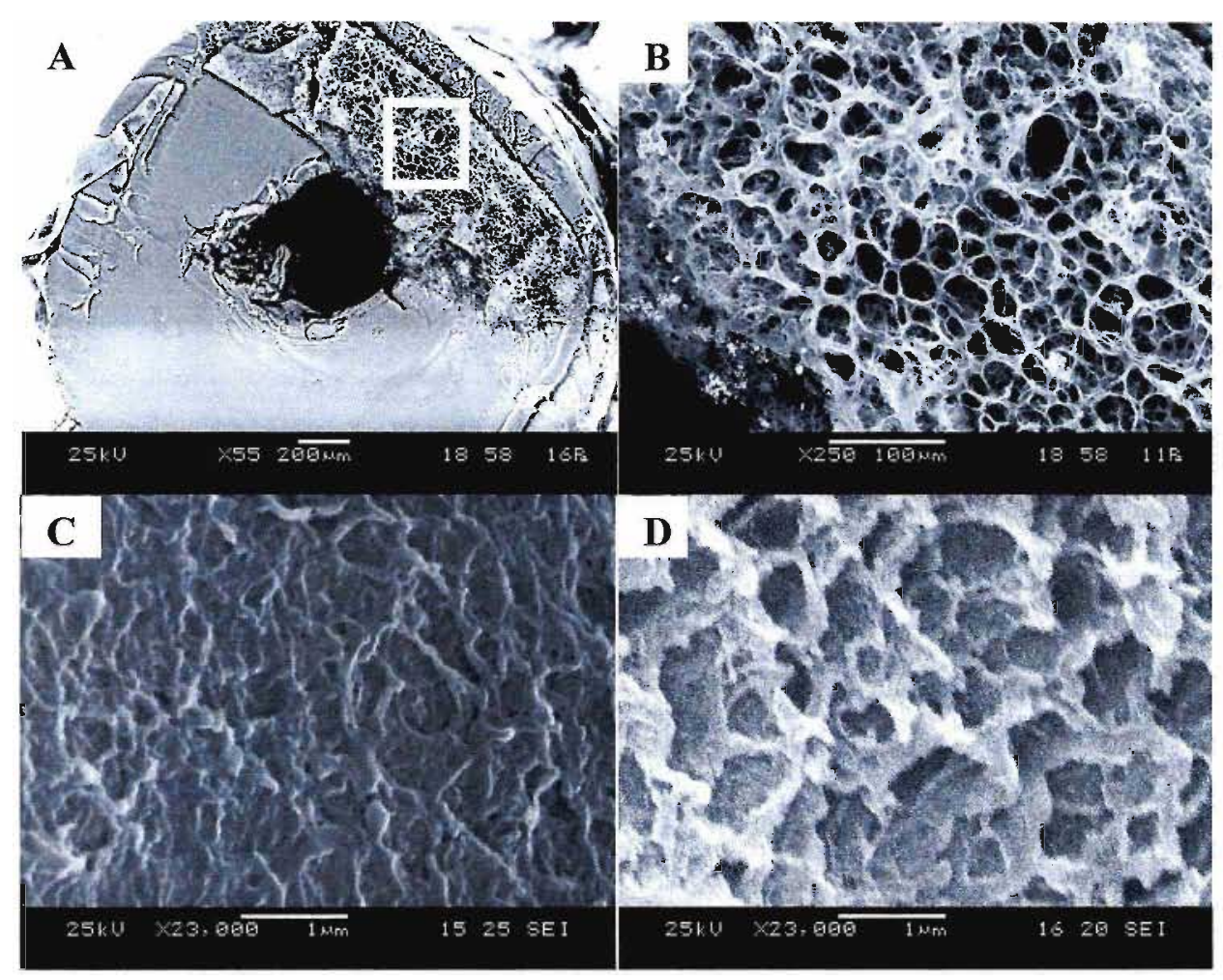

Figura 61 - Imagens de MEV para uma rede condutora semi-interpenetrante formada pela eletropolimerização de anilina no interior de um hidrogel 1. A imagem 61A (baixo vácuo) é da superfície gerada por um corte transversal do compósito. A imagem 61B (baixo vácuo) é a ampliação da região marcada na figura 61A. A imagem $61 \mathrm{C}$ é um corte transversal do compósito. A imagem 61D é um corte longitudinal do compósito.

A Figura 62 mostra imagens do compósito formado pelo hidrogel 11 e a polianilina. Na Figura 62A se vê que todo o hidrogel foi preenchido com uma carga de eletropolimerização menor do que a utilizada na síntese dos compósitos com os hidrogéis 1 e $2(7,5 \mathrm{C})$. Tal fato pode ser afirmado porque toda a superfície do compósito apresenta o mesmo aspecto, que por sua vez difere daquele visto na Figura 59A onde se tem o hidrogel 11; este comportamento está de acordo com o discutido anteriormente para os hidrogéis 1 e 2: sendo o hidrogel 11 o mais reticulado e o com menor tamanho de poro, será o preenchido mais rapidamente em todo o seu volume, e com uma quantidade menor de polianilina. A Figura 62B traz um detalhe da superfície do compósito mostrando sua homogeneidade e as estruturas que aparecem como saliências, podem ser um excesso de polianilina se acumulando na superfície. Um maior detalhe destas saliências pode ser visto na Figura $62 \mathrm{C}$ e corrobora a idéia de que sejam formadas pela polianilina se acumulando em pontos da superfície, pois são estruturas morfologicamente iguais à superfície que já estaria recoberta pelo polímero condutor. 
Finalmente, a Figura 62D mostra um corte transversal do compósito, revelando sua homogeneidade morfológica interna.

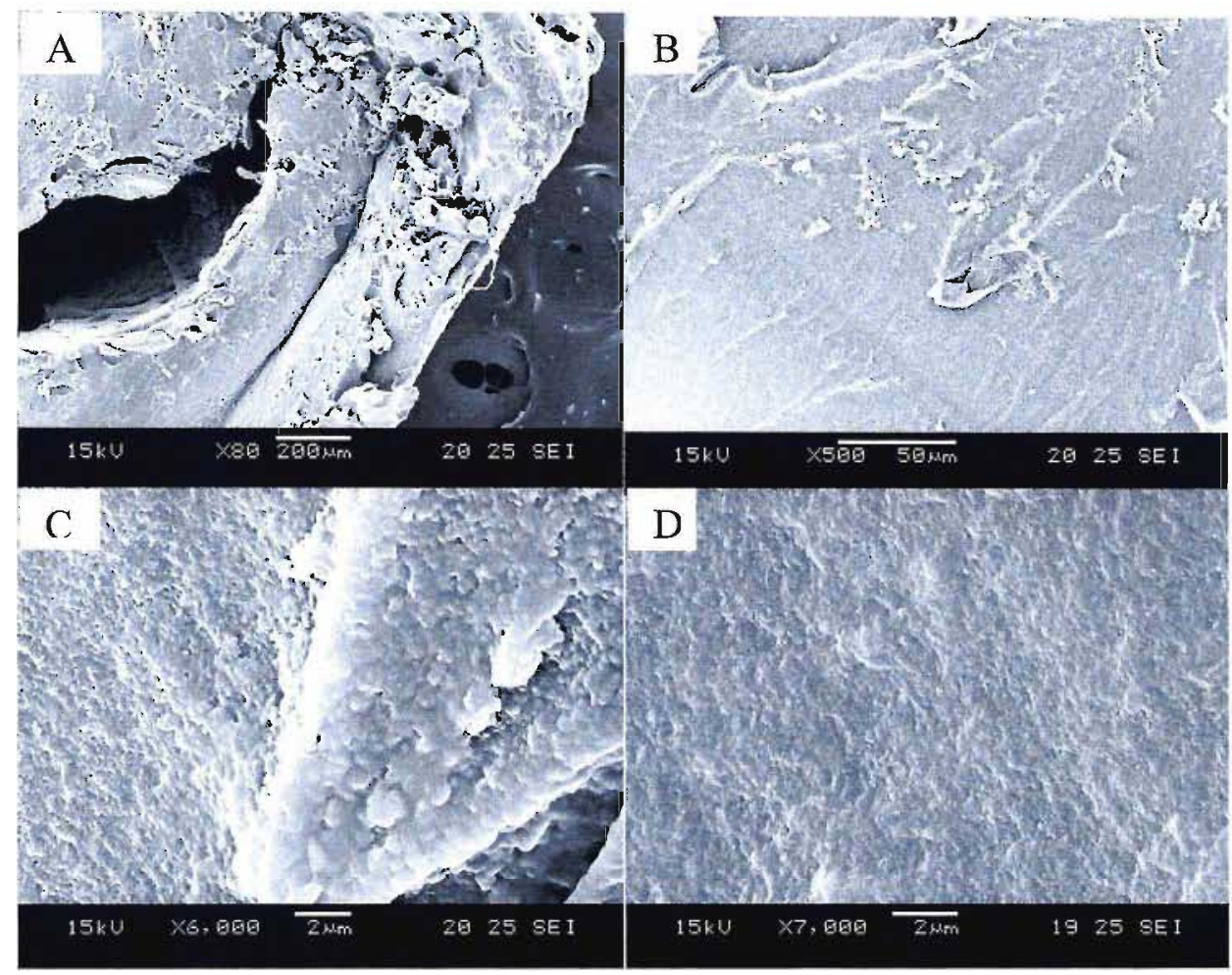

Figura 62 - Imagens de MEV para uma rede condutora semi-interpenetrante formada pela eletropolimerização de anilina no interior de um hidrogel 11. A -Superfície do compósito obtida após a eletropolimerização. B - Ampliação da imagem 62A. C Ampliação da imagem 62B. D - Imagem de um corte transversal do compósito.

4.3.7 - Redes condutoras semi-interpenetrantes de polianilina/poliacrilamida como sistemas de liberação controlada eletroquimicamente de moléculas-modelo

À caracterização morfológica e química do compósito formado pela eletropolimerização da anilina no interior de hidrogéis de poliacrilamida, segue-se o estudo da aplicação deste novo material em sistemas de liberação controlada de moléculas-modelo. Como requisitos básicos para este estudo fundamental, a moléculamodelo tem que ter razoável solubilidade em água, se mostrar inativa eletroquimicamente na maior faixa de potencial possível tanto sobre eletrodos de platina, como sobre a polianilina e também ser de fácil quantificação na solução de liberação. Preenchendo estas características tem-se a safranina, (Figura 63) um corante catiônico (sal quaternário de amônio) solúvel em água com $\lambda_{\text {máx }}=519 \mathrm{~nm}$ e massa molar igual a 
350,85 g.mol ${ }^{-1}$. A Figura 64 mostra os espectros de absorbância UV-Vis utilizados para se construir a curva analítica da safranina em água (também na Figura 64).A Figura 65 mostra os voltamogramas da safranina em meio ácido sobre platina e indicam um par redox ao redor de $-0,1 \mathrm{~V}$, porém é pequena a eletroatividade da safranina e sobre a polianilina não foi verificado nenhum processo eletroquímico. Em meio neutro o corante não é eletroativo. Também foi verificado que depois da oxidação/redução da safranina sobre platina e polianilina não há mudança nos espectro de absorção.<smiles>Cc1cc2nc3cc(C)c(N)cc3[n+](-c3ccccc3)c2cc1N</smiles>

Figura 63. Estrutura da safranina $\left(\mathrm{C}_{20} \mathrm{H}_{19} \mathrm{ClN}_{4}\right)$.
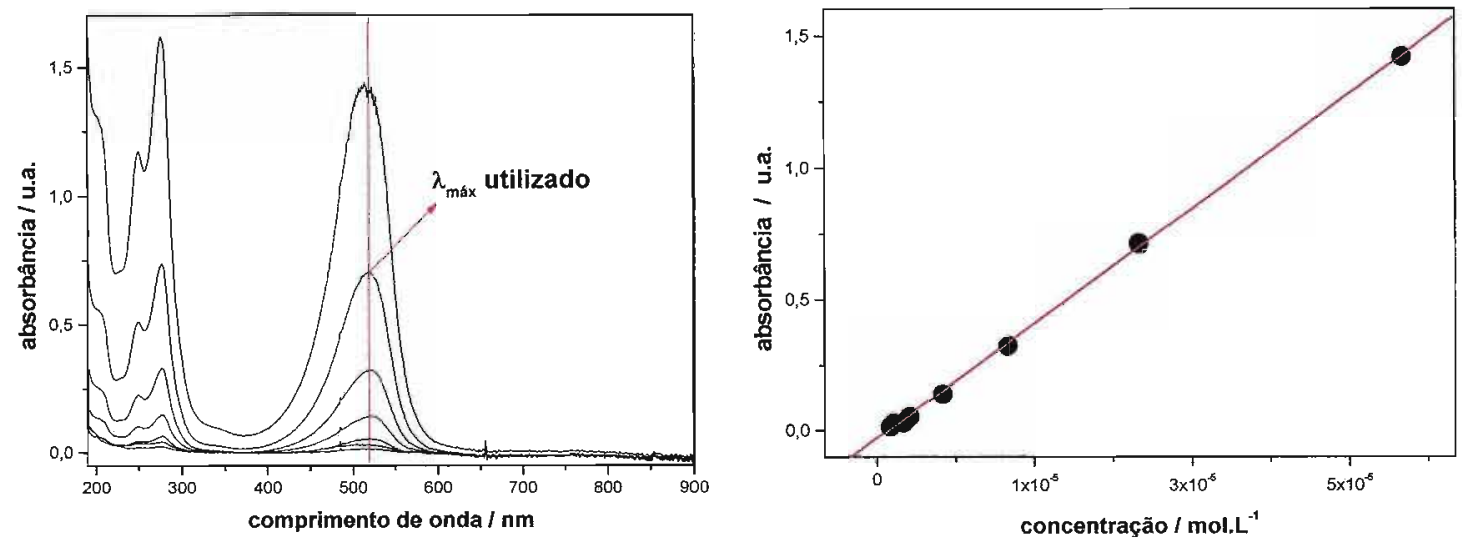

Figura 64 - Esquerda: Espectros de absorbância da safranina em água. $\lambda_{\text {máx }}=519 \mathrm{~nm}$. Direita: Curva analítica da safranina em água: Absorbância $=-0,0317+29107,4 x$ concentração. 


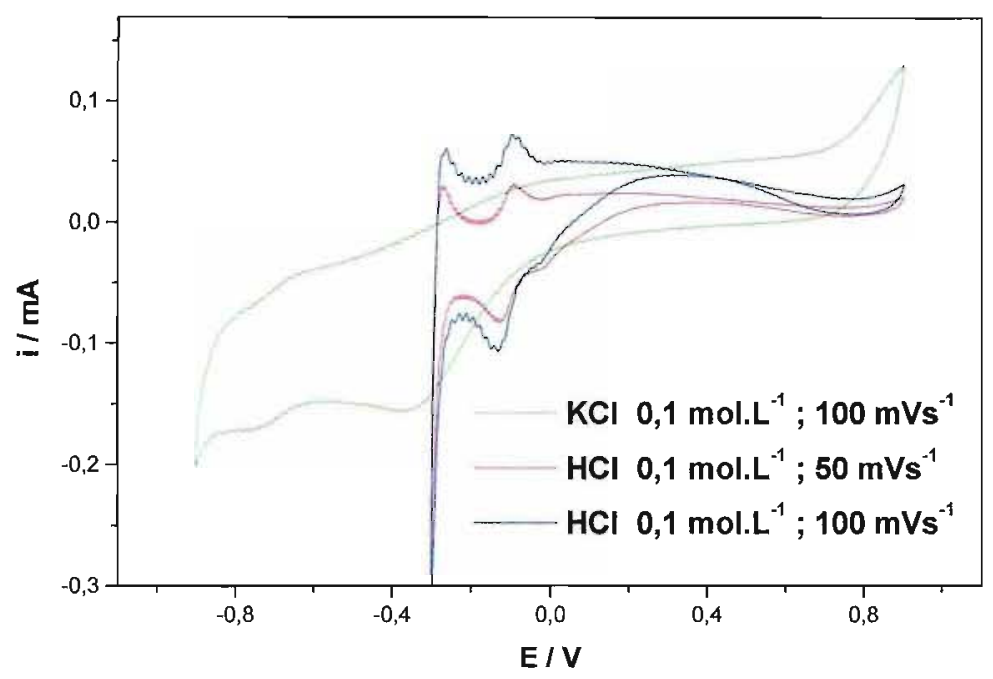

Figura 65 - Voltamogramas de soluções aquosas de safranina $0,1 \mathrm{~mol} . \mathrm{L}^{-1}$ sobre platina em diferentes eletrólitos suporte e diferentes velocidades de varredura.

4.3.7.1 - Estudo da liberação controlada eletroquimicamente de safranina a partir de compósitos de polianilina/poliacrilamida

Um fio de platina era inserido no centro de um hidrogel cilíndrico, este era deixado em repouso em solução contendo anilina $0,50 \mathrm{~mol} . \mathrm{L}^{-1}$ e $\mathrm{HCl} 1,0 \mathrm{~mol} . \mathrm{L}^{-1}$ durante uma noite. A síntese potenciostática $(0,75 \mathrm{~V})$ era realizada em célula eletroquímica convencional até determinados valores de carga, desta forma se controlava a quantidade de polímero condutor no compósito. O compósito pronto era deixado em repouso em água para se extrair os reagentes e subprodutos da polimerização por uma noite e depois secos em temperatura ambiente por no mínimo $4 \mathrm{~h}$. Transferia-se então o compósito para uma solução aquosa de safranina $5 \mathrm{mmol} . \mathrm{L}^{-1}$. Foi determinado, por medidas de massa, como é mostrado na Figura 66, o tempo mínimo de 4h necessário para se alcançar o intumescimento máximo de um hidrogel 1 de $80 \mu \mathrm{L}$, inicialmente seco, na solução de safranina $5 \mathrm{mmol} . \mathrm{L}^{-1}$. Este resultado pode ser extrapolado para os compósitos também, considerando os resultados de Wallace ${ }^{64}$, que mostram que a capacidade e cinética de intumescimento de compósitos de polianilina/poliacrilamida é praticamente o mesmo dos hidrogéis sozinhos. Todavia, a Figura 67 compara as curvas de liberação de safranina de dois compósitos idênticos de polianilina/poliacrilamida a ECA, um carregado em $12 \mathrm{~h}$ e outro em $60 \mathrm{~h}$, não é verificada nenhuma diferença na quantidade total de corante liberado. 


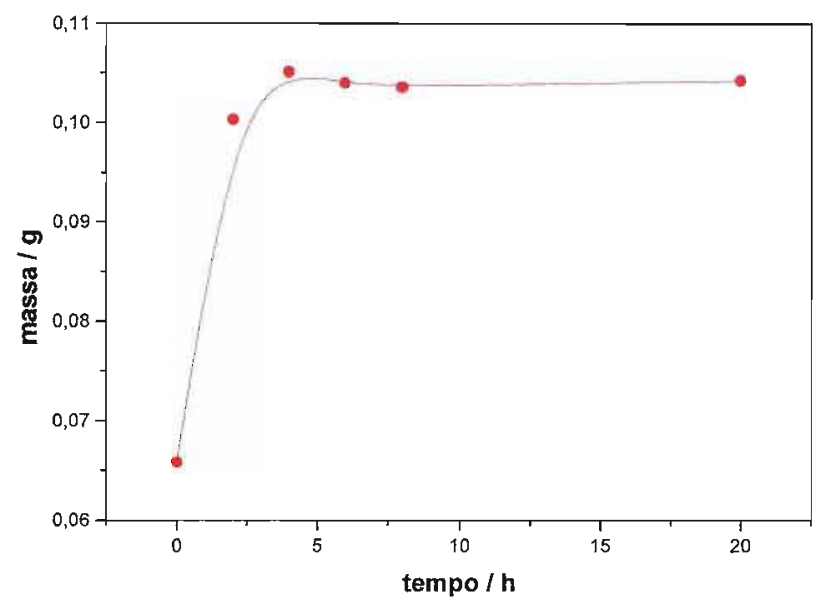

Figura 66 - Determinação da cinética de intumescimento de um hidrogel 1 de $80 \mu \mathrm{L}$.

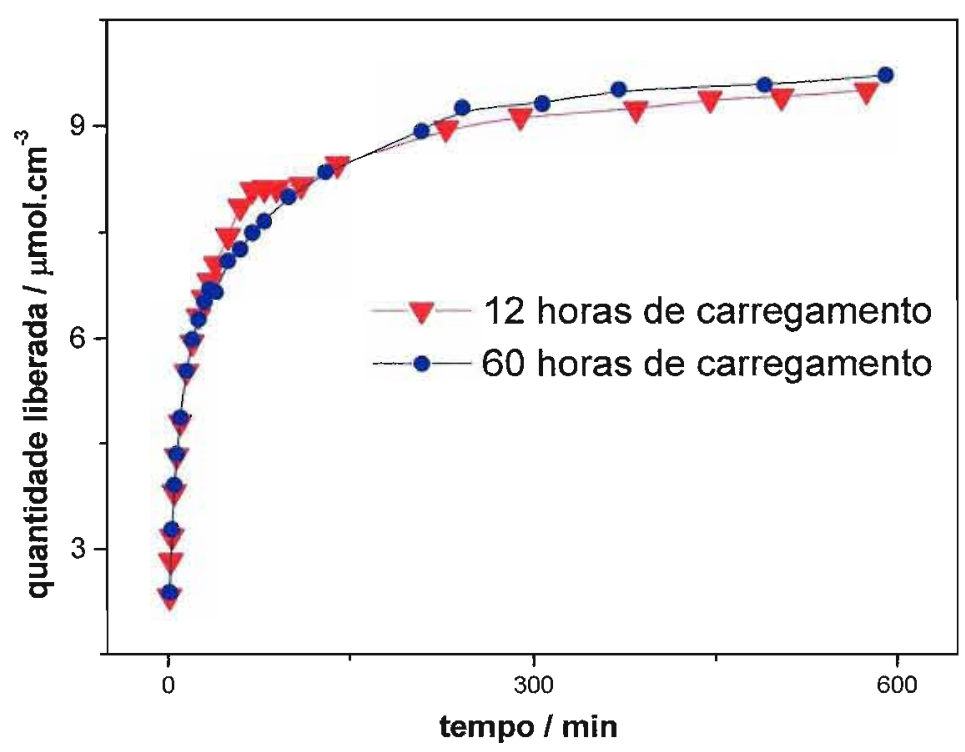

Figura 67 - Curvas de liberação de safranina em solução de $\mathrm{HCl} 0,10 \mathrm{~mol} . \mathrm{L}^{-1}$ a partir de compósitos de polianilina/poliacrilamida carregados em diferentes tempos. Notar a excelente reprodutibilidade das curvas de liberação obtidas a partir de dois compósitos iguais.

Nesta seção serão mostrados vários experimentos onde são estudados parâmetros como o hidrogel utilizado no compósito, a quantidade de polianilina no compósito (determinada pela carga passada durante a eletropolimerização), e o pH da solução de liberação. Para facilitar a escrita e a identificação dos parâmetros de cada experimento, será utilizada a seguinte notação para cada compósito estudado: Hn-X, onde Hn indicará o hidrogel utilizado, por exemplo, se a composto foi formado entre a polianilina e o hidrogel $1, \mathrm{H}$ n será $\mathrm{H} 1$; X indicará a carga utilizada na síntese do compósito, por 
exemplo, uma eletropolimerização onde foram consumidos $8,5 \mathrm{C}$ de carga para gerar o polímero condutor terá $\mathrm{X}=8,5$. Assim ter-se-á compósitos descritos como H1-8,5.

Os experimentos de liberação tiveram que ser otimizados no que se refere ao volume do compósito utilizado, concentração da solução de carregamento e volume da solução de liberação, a fim de se conseguir uma liberação que pudesse ser acompanhada tanto em relação à quantidade de safranina liberada, quanto em relação ao tempo de liberação. Foram testadas as liberações de compósitos de 50, 80 e $200 \mu \mathrm{L}$, carregados com soluções de safranina de $0,01 \mathrm{~mol} . \mathrm{L}^{-1}$, esta concentração é muito alta, pois a liberação dura mais de 24h. Compósitos carregados com solução de safranina $0,1 \mathrm{mmol} . \mathrm{L}^{-1}$ não liberam safranina suficiente para ser detectada. Todos estes testes prévios foram realizados em diferentes volumes da solução de liberação. Por fim o carregamento de compósitos de $50 \mu \mathrm{L}$ com solução de safranina $5 \mathrm{mmol} . \mathrm{L}^{-1}$ e a liberação realizada em $50 \mathrm{ml}$ de solução aquosa de $\mathrm{HCl}$ foi a combinação escolhida para se realizar todos os testes de liberação. Foi verificado em alguns testes de liberação controlada com o potencial, que conforme se mantinha o potencial catódico no compósito, a corrente/potencial gerado no eletrodo auxiliar era positiva o suficiente para degradar a safranina presente em solução. Dessa forma, para se defenir completamente uma metodologia para os testes de liberação controlada de safranina foi necessário isolar o eletrodo auxiliar da solução de liberação colocando-o num compartimento separado e promovendo o contato elétrico através da junção líquida que se fez com a utilização de um gel de ágar.

Foi observado que para preencher (visualmente) todo um hidrogel 1 de $50 \mu \mathrm{L}$ com polianilina eram necessários $8,5 \mathrm{C}$ de carga, desta forma o compósito padrão foi o H1-8,5. Voltamogramas do compósito $H 1-8,5$ já foram mostrados na Figura 42 e discutidos na seção 4.3.1.

A Figura 68 mostra as curvas de liberação de safranina a partir de compósitos H1-8,5 em diferentes potenciais; estas curvas são diferentes quando se comparam o estado reduzido e a ECA com o estado oxidado, seja qual for o mecanismo, compensação de carga ou volume do polímero condutor dentro do hidrogel, é fato que no estado reduzido o compósito retém mais safranina. Considerando que a liberação da safranina controlada por difusão ocorre de forma similar tanto no compósito reduzido como no oxidado e isto pode ser corroborado pela semelhança das curvas de liberação, em diferentes potenciais, no inicio do experimento, a resposta eletroquímica seria 
melhor observada em tempos maiores de liberação, onde o controle difusional já não é tão importante. Assim para comprovar que no estado reduzido o compósito retém mais safranina que no estado oxidado, optou-se por realizar a liberação da seguinte forma: inicia-se a liberação com o compósito reduzido e quando a velocidade de liberação diminuir drasticamente, quase atingindo um patamar, se aplica um pulso de potencial oxidando-o.

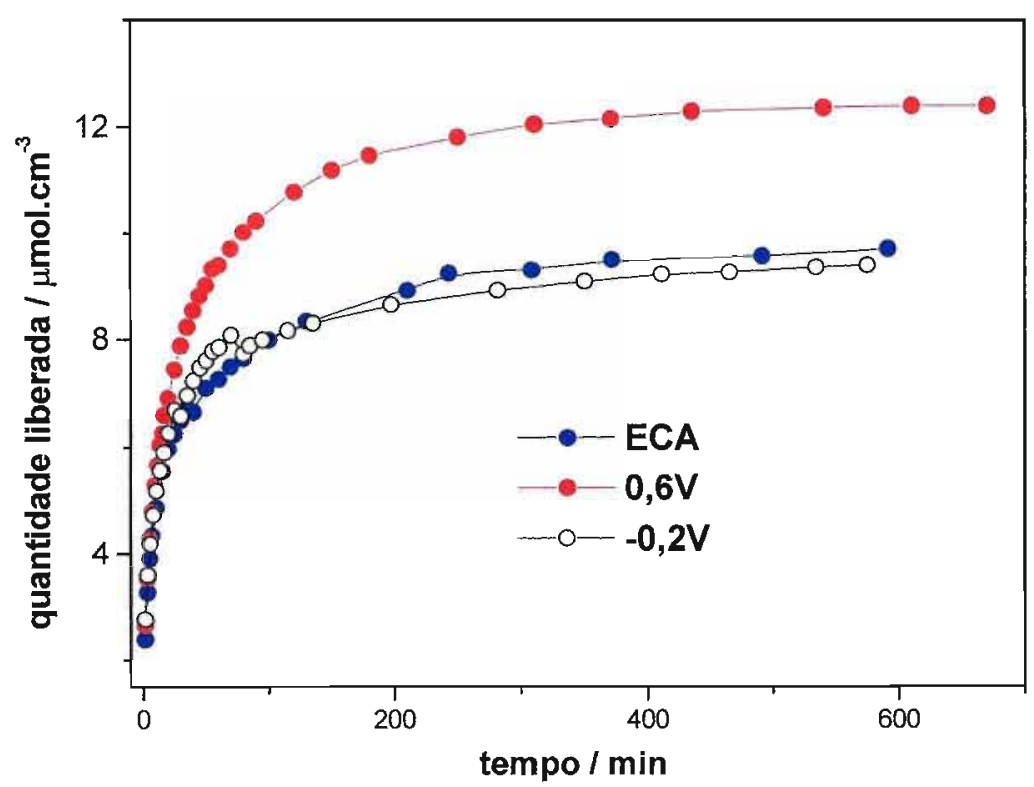

Figura 68 - Curvas de liberação em diferentes potenciais de safranina a partir de compósitos H1-8,5. pH da solução de liberação $=1$.

Como se pode ver na Figura 69, o experimento proposto foi efetivo em se demonstrar o controle eletroquímico na liberação de safranina, ou seja, a velocidade de liberação pode ser alterada pelo controle do estado de oxidação da rede condutora. Este procedimento foi então adotado para se verificar o controle eletroquímico na liberação de safranina a partir de diferentes compósitos e diferentes condições experimentais. Ajustando linearmente as regiões próximas à mudança de potencial, e considerando o coeficiente angular de cada reta como a velocidade de liberação, tem-se uma forma de quantificar a variação de velocidade conseguida em cada experimento. Nesta tese defini-se a eficiência do controle eletroquímico $(\phi)$ como a relação:

$$
\phi=\Delta \mathbf{V} / \mathbf{V}_{\text {red }}
$$


onde $\Delta \mathrm{V}=\mathrm{V}_{\text {oxi }}-\mathrm{V}_{\text {red }}, \mathrm{V}_{\text {oxi }}=$ velocidade de liberação no estado oxidado e $\mathrm{V}_{\text {red }}=$ velocidade de liberação no estado reduzido. A Figura 70 traz este tratamento para a liberação apresentada na Figura 69.

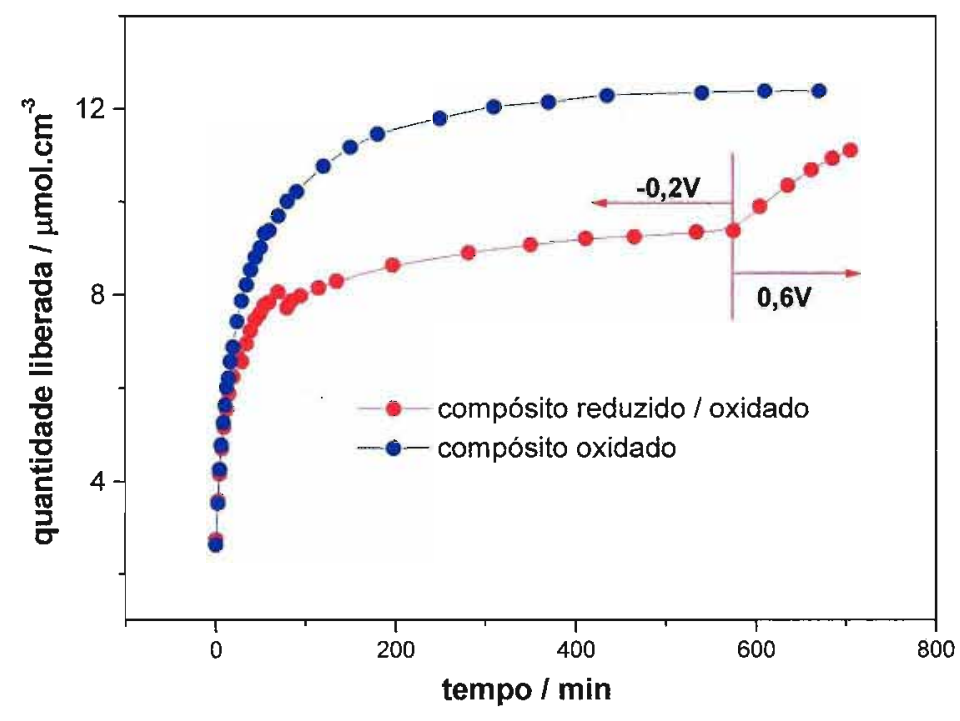

Figura 69 - Curvas de liberação em diferentes potenciais de safranina a partir de compósitos H1-8,5. pH da solução de liberação $=1$.

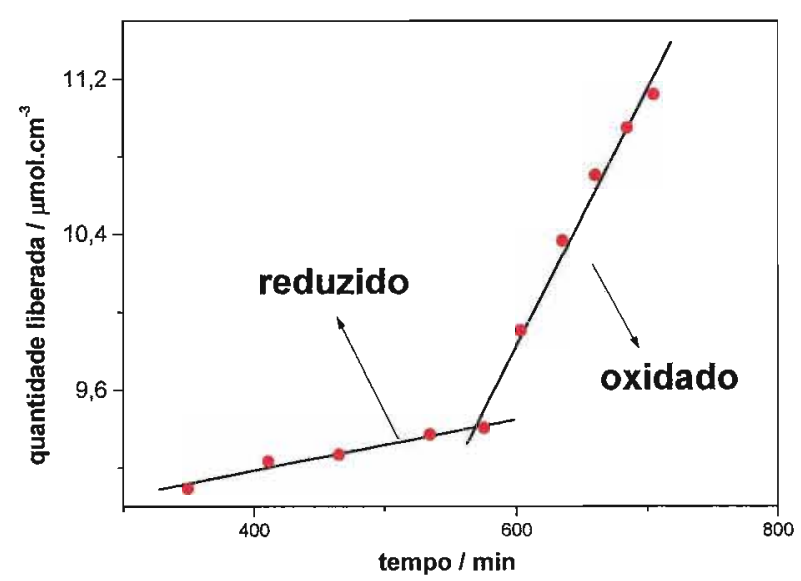

Figura 70 - Mudança de velocidade de liberação em função do estado de oxidação do compósito H1-8,5. $\phi=8,92$.

4.3.7.1.1 - Efeito do pH da solução de liberação

Desde os primeiros e clássicos trabalhos sobre a polianilina é conhecida a dependência da sua eletroatividade com o $\mathrm{pH}$. Portanto não seria diferente que esta dependência para os compósitos de polianilina/poliacrilamida. As Figuras 71 e 72 
trazem voltamogramas dos compósitos $\mathrm{H} 1-8,5$ em diferentes pHs e mostram o esperado: o aumento da eletroatividade com a diminuição do $\mathrm{pH}$ do meio. Curvas de liberação em diferentes pHs são mostradas nas Figuras 73 e 74. Não há o controle eletroquímico da liberação quando realizada em $\mathrm{pH}=3,2$, pois o compósito é muito pouco eletroativo, e a curva se assemelha àquela realizada com o compósito oxidado e em $\mathrm{pH}=1$ (Figura 74). Surpreendentemente também não houve controle eletroquímico da liberação realizada em $\mathrm{pH}=0$ (Figura 73), embora o compósito seja mais eletroativo neste meio do que em $\mathrm{pH}=1$. Como se liberou menos safranina independentemente do estado de oxidação do compósito, acredita-se que se tenha protonado o corante e desta forma ele poderia fazer mais ligações de hidrogênio com a polianilina (grupos amina e imina) e com a poliacrilamida (grupos hidroxila). Interagindo mais com o compósito a safranina sairia em menor quantidade e não responderia ao pulso de potencial.

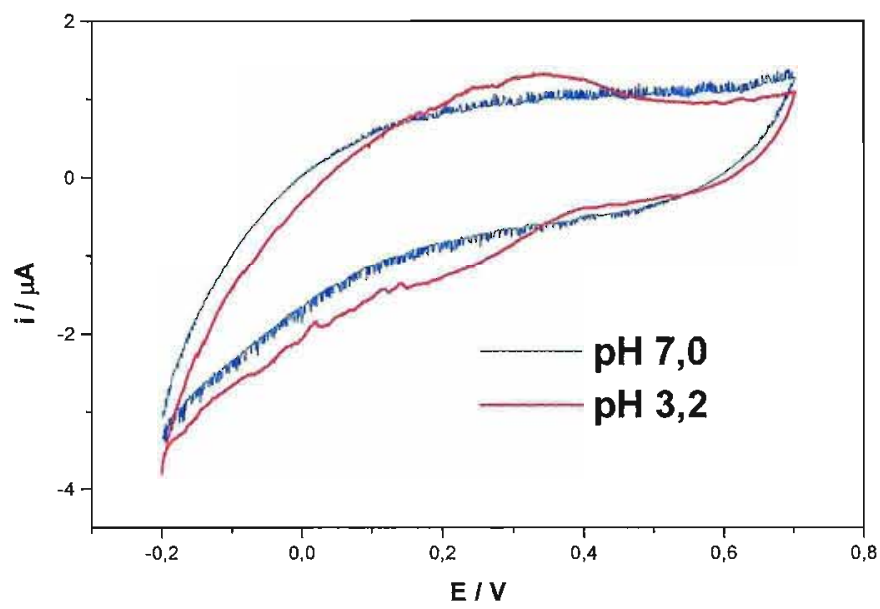

Figura 71 -Voltamogramas de um compósito $H 1-8,5$ em diferentes pHs. Velocidade de varredura: $1 \mathrm{mVs}^{-1}$.

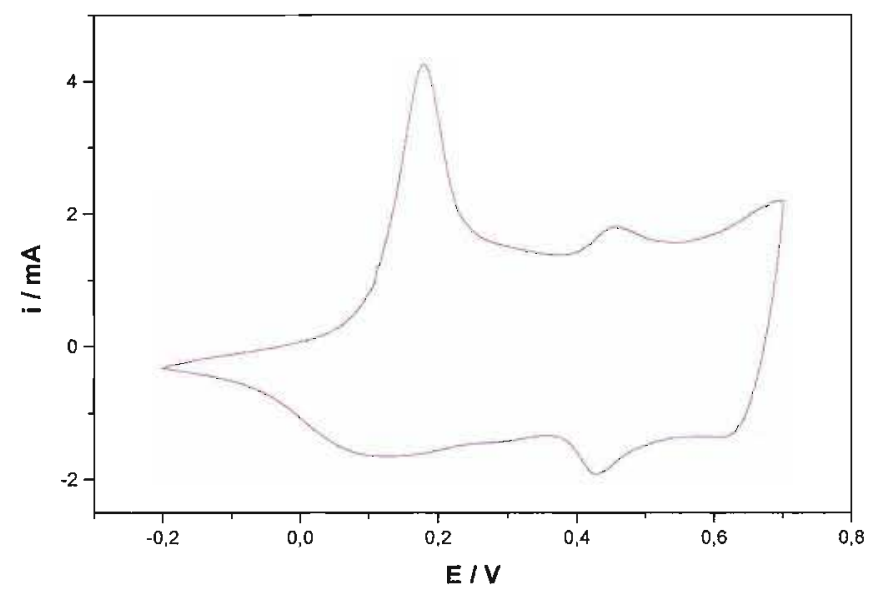

Figura 72 - Voltamograma de um compósito H1-8,5 em HCl 1,0mol.L $\mathrm{L}^{-1}$. Velocidade de varredura: $1 \mathrm{mVs}^{-1}$. 


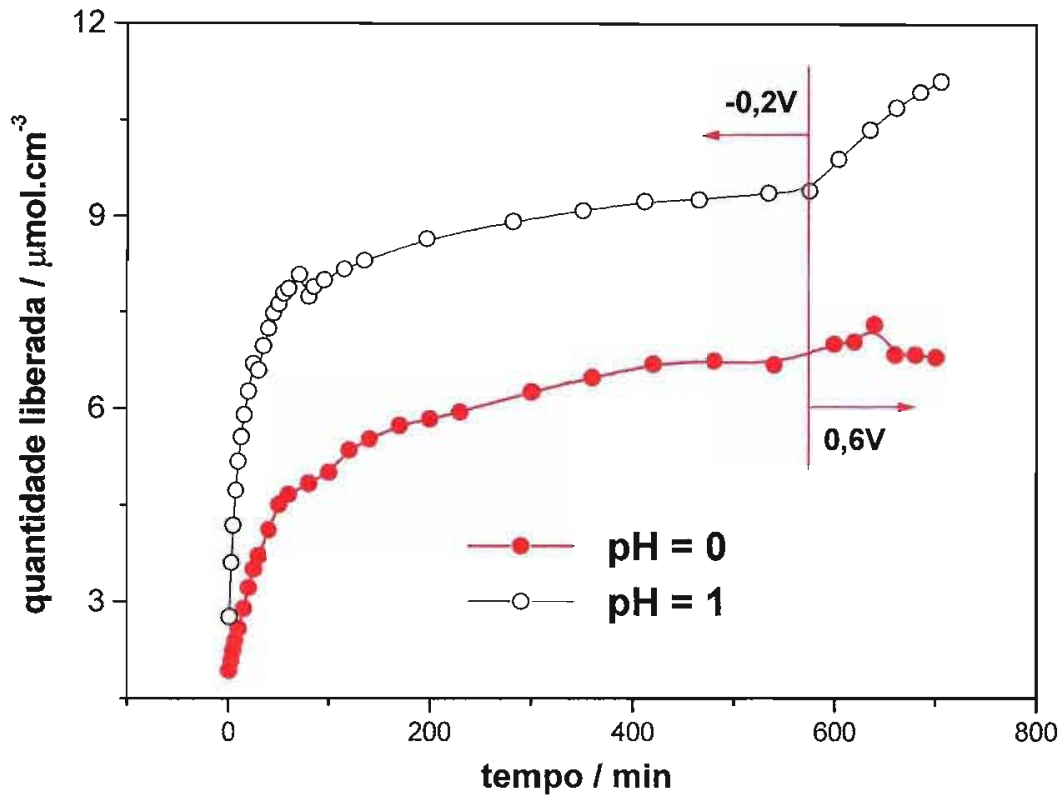

Figura 73 - Curvas de liberação em diferentes potenciais e diferentes pHs (compósitos H1-8,5).

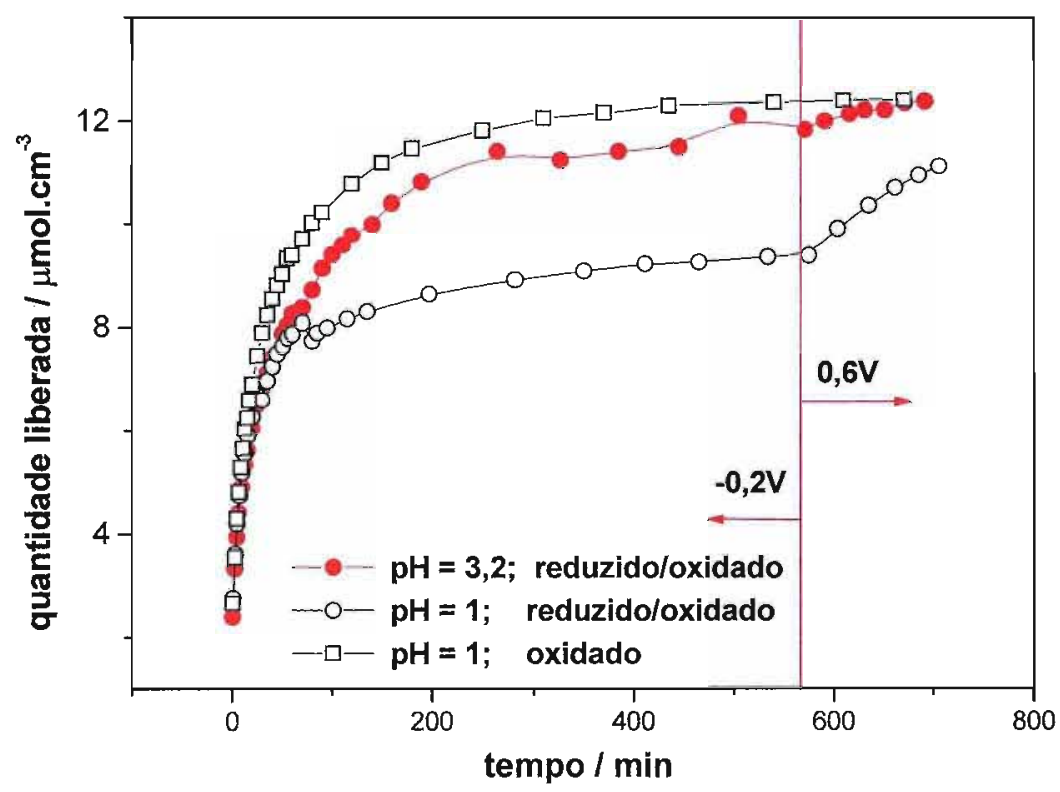

Figura 74 - Curvas de liberação em diferentes potenciais e diferentes pHs (compósitos H1-8,5). 
4.3.7.1.2 - Efeito da quantidade de polianilina no compósito: carga de eletropolimerização

Lembrando que a carga mínima para se preencher (visualmente) todo um hidrogel 1 é de $8,5 \mathrm{C}$, se estudou o efeito da quantidade de polímero (presente no hidrogel) no controle eletroquímico da liberação através da síntese de compósitos com $4,0,17,0$ e 34,0C de carga. Foi verificado que para um compósito de $50 \mu \mathrm{L}$, a polianilina começa a crescer na superfície do hidrogel a partir de $20,0 \mathrm{C}$, portanto não foi possível a síntese do compósito $H 1-34$. O cronoamperograma para a síntese do compósito $H 1-4,0$ já foi mostrado (Figura 43) e discutido na seção 4.3.1. Com a interrupção da polimerização com 4,0C de carga, obtém-se um compósito parcialmente preenchido com polímero condutor e espera-se que a eficiência do controle eletroquímico seja menor do que aquela obtida do compósito $H 1-8,5$. De fato a Figura 75 mostra que o compósito H1-4,0 no estado reduzido retém menor quantidade de safranina e quando oxidado a mudança de velocidade é menor (comparado com o compósito H1-8,5).

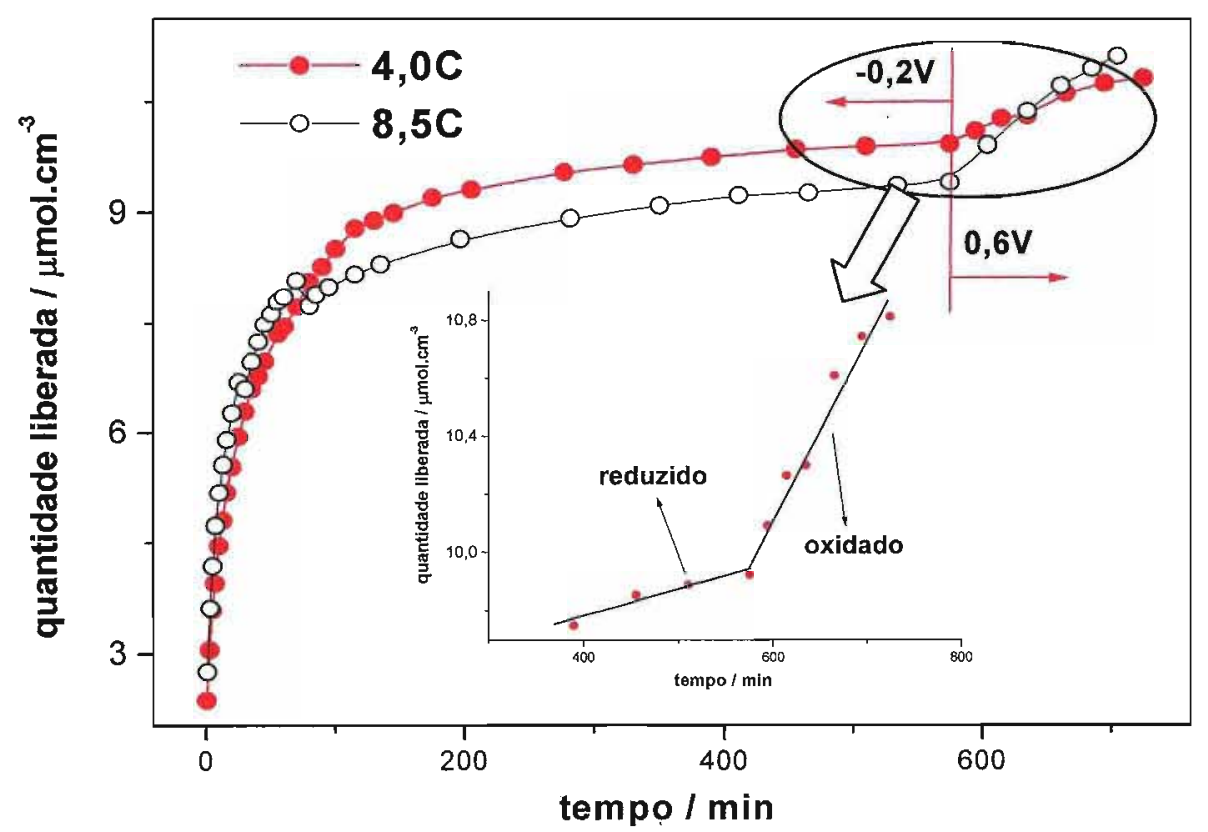

Figura 75 - Curvas de liberação a diferentes potenciais (compósitos H1-8,5 e H1-4,0). Detalhe: Mudança de velocidade de liberação em função do estado de oxidação do compósito $H 1-4,0 . \phi=2,16$. 
Já no caso do compósito $H 1-17,0$, a grande quantidade de polímero condutor na matriz de poliacrilamida torna o compósito mais resistivo, como pode ser visto no voltamograma da Figura 76, que o H1-8,5 .É mostrado na Figura 77 que este compósito menos eletroativo tem também uma menor $\phi$ comparada com a eficiência do compósito $H 1$-8,5. Ainda em relação ao compósito $H 1-17,0$, a Figura 78 mostra que a maior quantidade de polímero condutor não impede que o compósito seja carregado com a mesma quantidade de safranina que entra na rede $H l-8,5$, assim tem-se mais uma evidência que a diferença em $\phi$ é causada pela diferente eletroatividade dos compósitos.

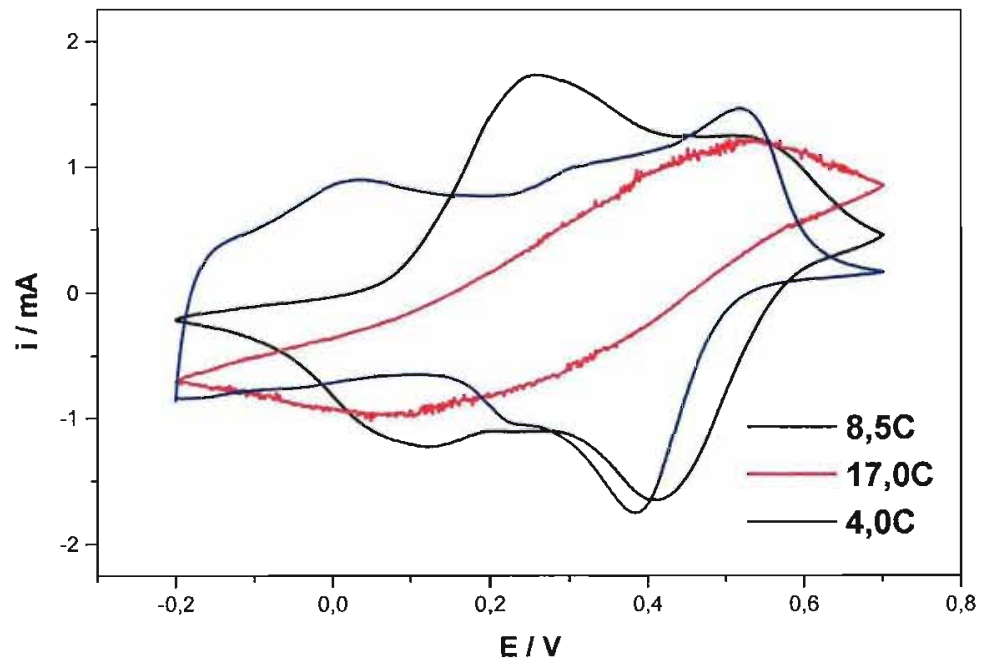

Figura 76 - Voltamogramas dos compósitos $H 1-8,5, H 1-4,0$ e $H 1-17,0 . \mathrm{v}=1 \mathrm{mVs}^{-1}, \mathrm{pH}$ $=1$. 


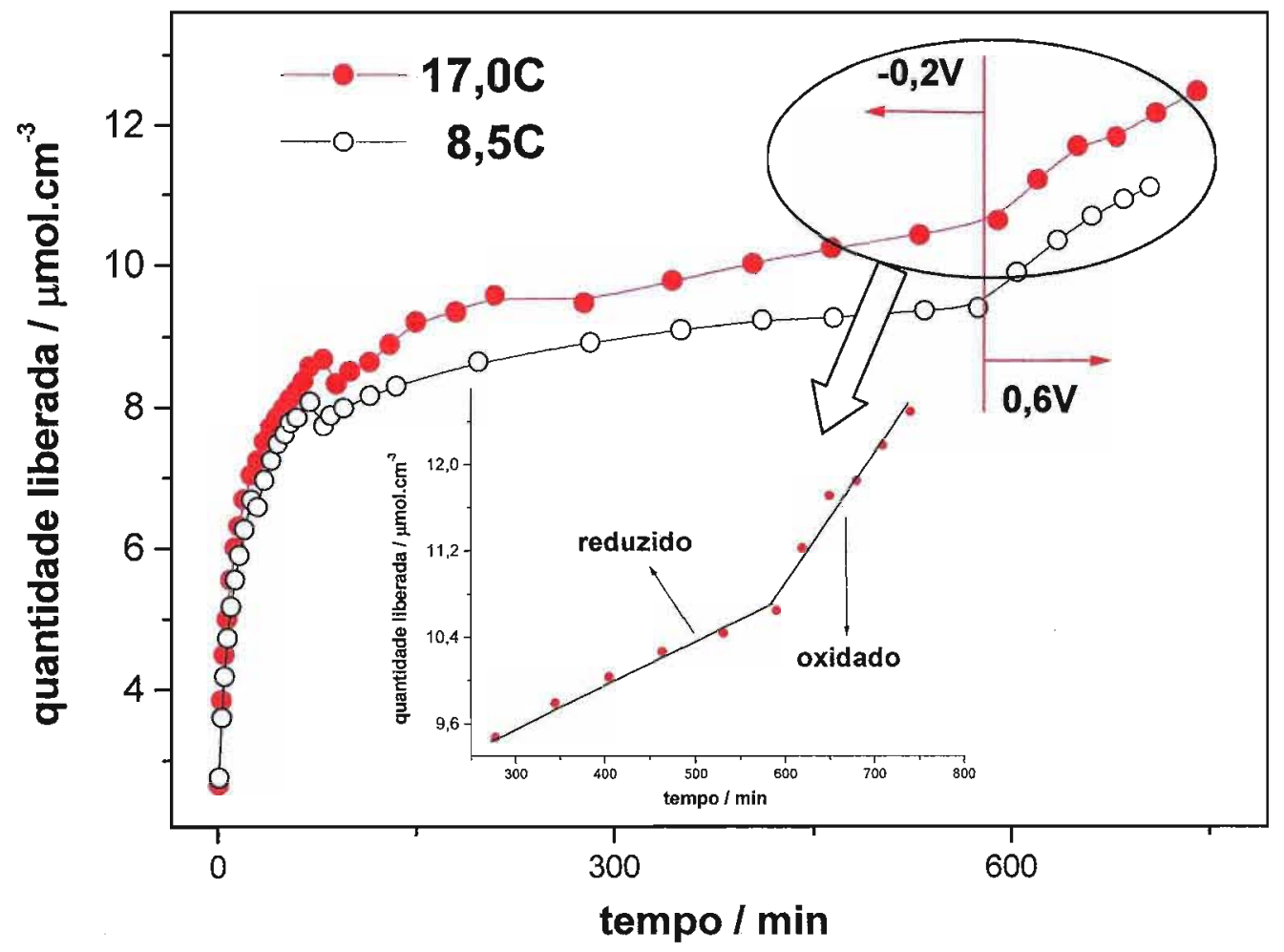

Figura 77 - Curvas de liberação a diferentes potenciais (compósitos H1-8,5 e H1-17,0). Detalhe: Mudança de velocidade de liberação em função do estado de oxidação do compósito $H 1-17,0 . \phi=5,78$.

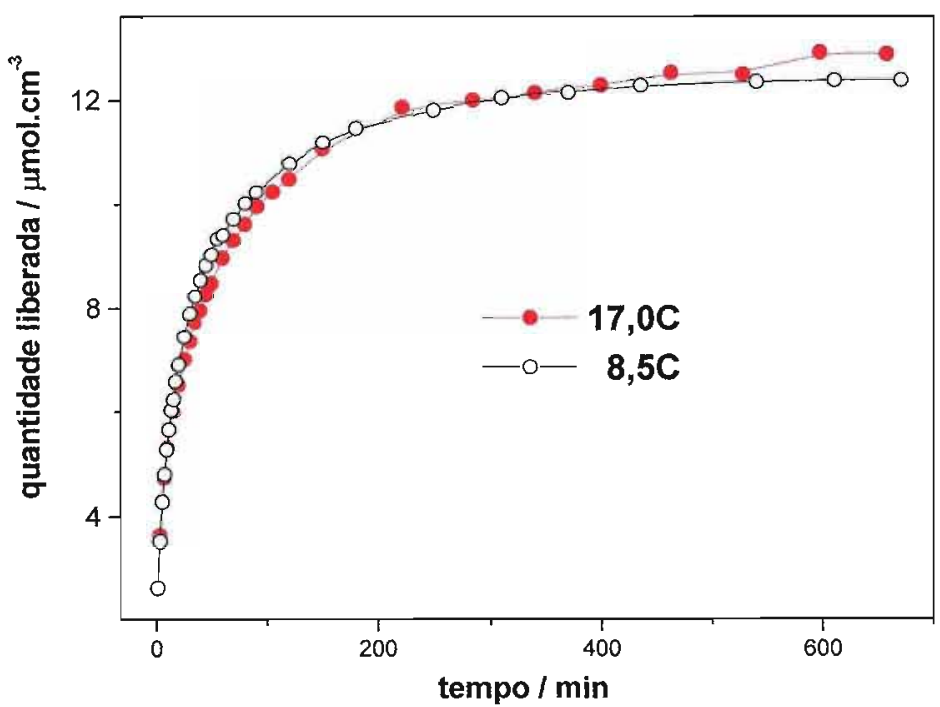

Figura 78 - Curvas de liberação a 0,6V (compósitos H1-8,5 e H1-17,0). 
4.3.7.1.3 - Efeito dos diferentes tamanhos de poros das matrizes de poliacrilamida

Avaliou-se a resposta eletroquímica na liberação de safranina utilizando-se compósitos formados com os hidrogéis 1,2 e 11 . Novamente o hidrogel 1 se situa no meio, como padrão, e os outros dois hidrogéis estão no limite superior e inferior (em relação ao total de 11 hidrogéis diferentes) de porosidade.

De acordo com a Figura 79 é mais difícil crescer a polianilina dentro de um hidrogel 2 do que dentro de um hidrogel 1, todavia o hidrogel 2 tem uma estrutura mais aberta, então a menor velocidade de crescimento do polímero condutor pode estar relacionada com a distribuição do mesmo no hidrogel como verificado nas imagens de MEV mostradas na seção 4.3.6.2. Já o hidrogel 11, parece oferecer uma maior dificuldade ao crescimento da polianilina (Figura 79) devido ao menor tamanho de poro e ao menor espaço livre na rede tridimensional. A suposição de que a rede do hidrogel 11 tem menos espaço livre é corroborada pelo fato de que para se preencher esta matriz é necessária menos carga de polimerização $(\sim 7,5 \mathrm{C})$ e também por imagens de MEV. Portanto para o hidrogel 11, o valor de carga de 7,5C é considerado equivalente aos $8,5 \mathrm{C}$ para os outros hidrogéis. Os voltamogramas dos compósitos $H 1-8,5, H 2-8,5$ e H11-7,5 são mostrados na Figura 80.

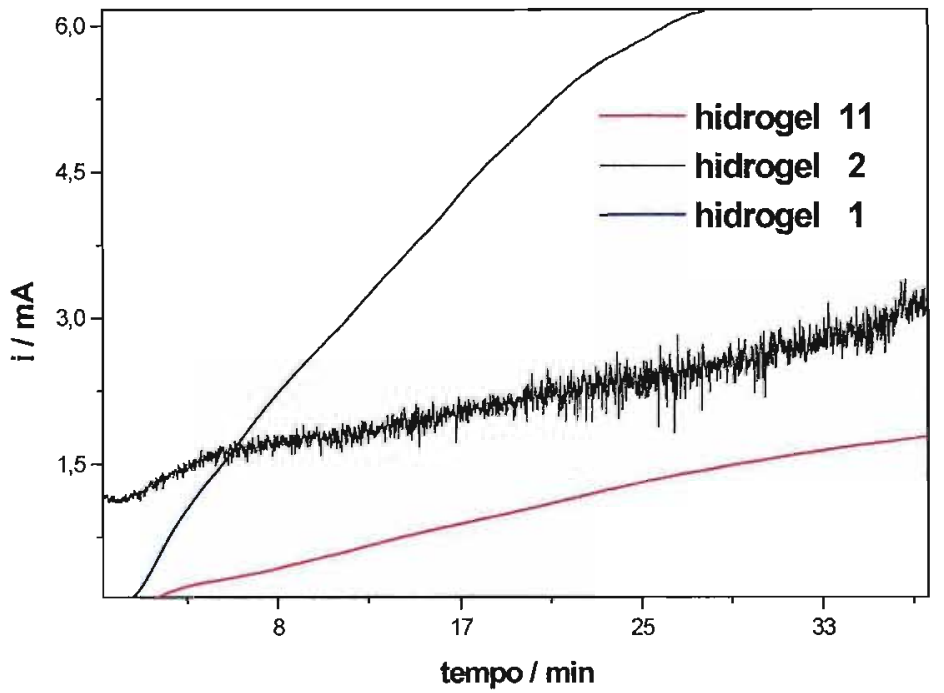

Figura 79 - Cronoamperogramas das sínteses de compósitos H1-8,5, H2-8,5 e H11-7,5. 


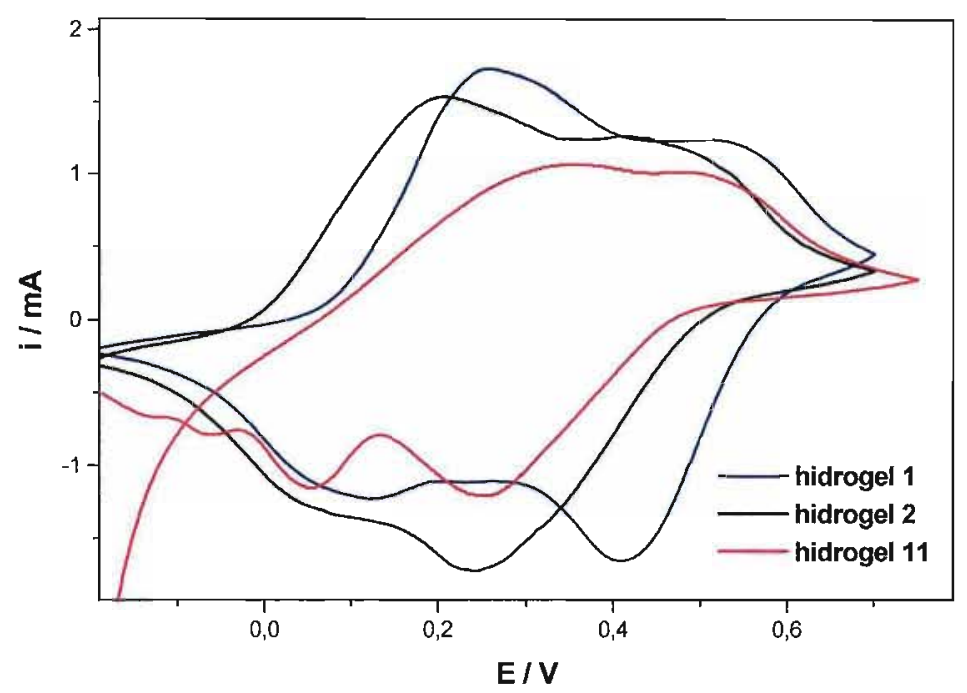

Figura 80 - Voltamogramas dos compósitos $H 1-8,5, H 2-8,5$ e $H 11-7,5 . \mathrm{v}=1 \mathrm{mVs}^{-1}$, $\mathrm{pH}=1$.

A Figura 81 mostra que o compósito $H 2-8,5$ tem a melhor resposta eletroquímica, pois a velocidade de liberação no estado reduzido é muito baixa e o pulso de potencial provoca um aumento de praticamente duas ordens de grandeza na velocidade de liberação. A Figura 82 mostra que para o compósito H11-7,5 tem-se exatamente o contrário, quase não há diferença nas duas velocidades de liberação.
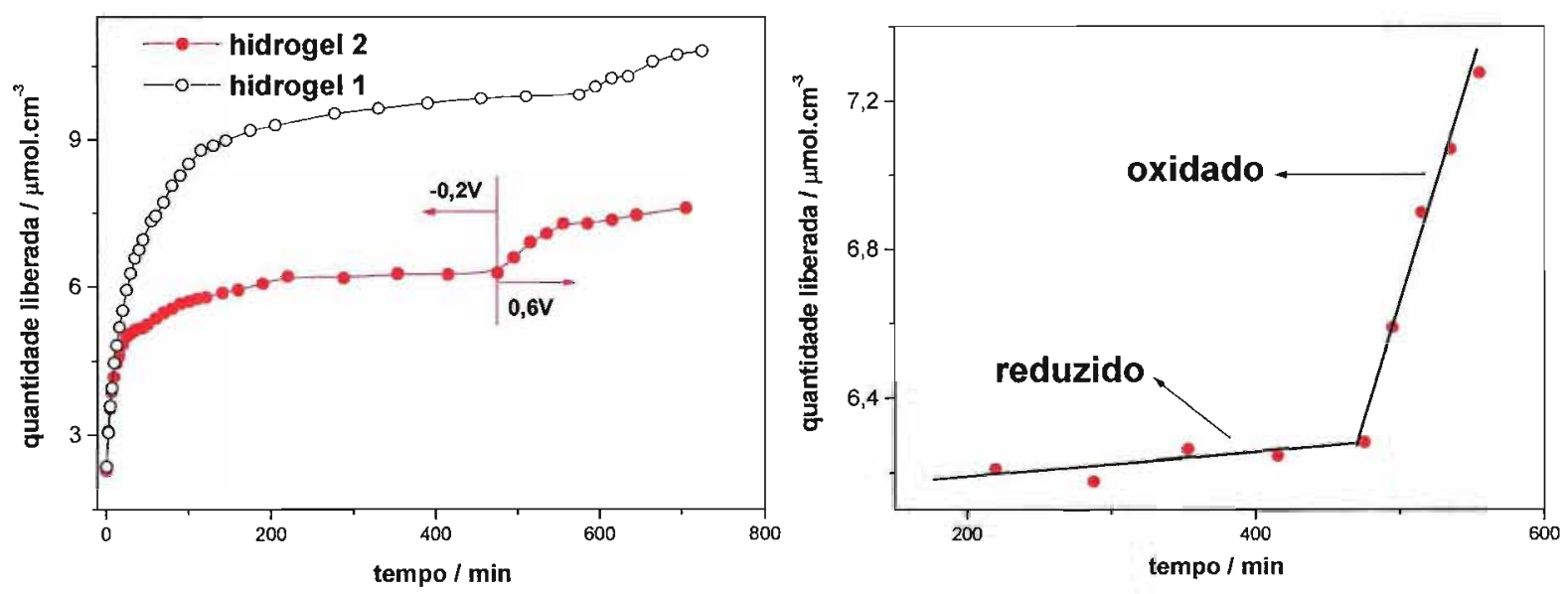

Figura 81 - Esquerda: curvas de liberação a diferentes potenciais (compósitos H1-8,5 e H2-8,5). Direita: mudança de velocidade de liberação em função do estado de oxidação do compósito $H 2-8,5$. $\phi=37,39$. 

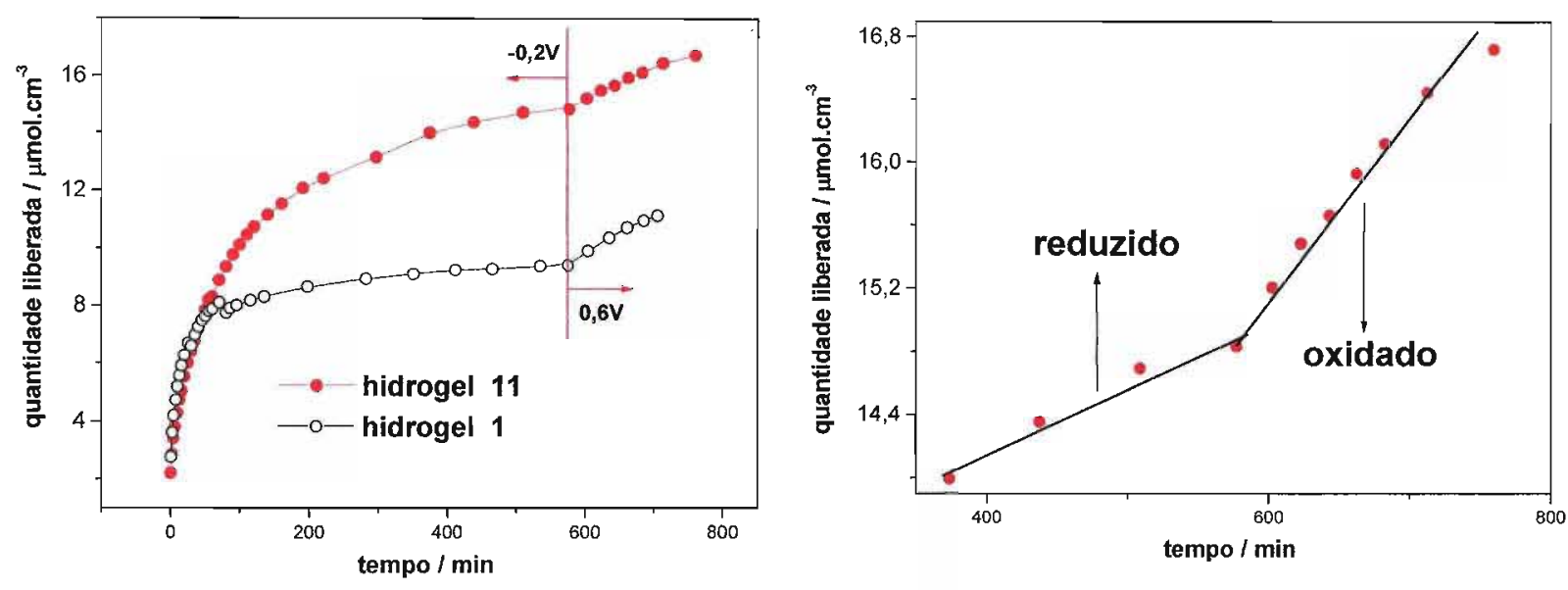

Figura 82 - Esquerda: curvas de liberação a diferentes potenciais (compósitos H1-8,5 e H1 1-7,5).Direita: mudança de velocidade de liberação em função do estado de oxidação do compósito $H 11-7,5 . \phi=1,48$.

4.3.7.2 - Comparação e análise dos resultados da parametrização da liberação de safanina

É importante destacar alguns pontos referentes à parametrização da liberação controlada de safranina: Por ser um trabalho de fato inovador, falta na literatura uma fonte para comparação dos resultados aqui apresentados. Procurando resultados similares na liberação controlada utilizando somente polímeros condutores, Reynolds ${ }^{26}$ fornece um valor para a velocidade de liberação de ATP a partir de membranas de polipirrol no seu estado reduzido: $15-35 \mathrm{nmol} . \mathrm{cm}^{-2} \cdot \mathrm{min}^{-1}$, porém não faz sentido comparar este valor com os desta tese (ver tabela 12, a seguir), pois aqui a liberação foi realizada utilizando-se compósitos com volume e não de membranas bidimensionais. Além disso, Reynolds não mostra diferenças na velocidade de liberação em função do estado de oxidação da membrana e não considera a liberação controlada basicamente por difusão, lembrando que os valores de velocidade de liberação apresentados na tabela 12 se referem a estágios de liberação aonde a difusão já não é mais tão importante. Wallace $^{71}$ demonstrou a liberação de calcon a partir de um compósito de polipirrol/poliacrilamida no seu estado reduzido, porém também não comparou com a liberação a ECA, nem com o compósito oxidado, também não forneceu valor de velocidade de liberação.

Com os resultados referentes ao estudo da Geração II, foi alcançado o objetivo de sintetizar compósitos contendo polímeros condutores com a capacidade de controlar 
eletroquimicamente a liberação de moléculas-modelo. E mesmo que na proposta inicial da Geração II se tenha abdicado da procura de um sistema capaz de acionar a liberação num tempo qualquer (propriedade de liga/desliga), os resultados mostrados na Figura 81 indicam que, descontada a liberação controlada por difusão, é possível obter uma excelente resposta na liberação por um impulso eletroquímico, uma vez que a saída de safranina havia quase cessado enquanto se mantinha o compósito reduzido e ao oxidá-lo verificou-se um considerável aumento na velocidade de liberação e na quantidade total liberada (ver tabela 12). Outro ponto de destaque que supera em muito os sistemas da Geração I é a boa reprodutibilidade das curvas de liberação, em especial a vista na Figura 67.

Para melhor visualizar os resultados obtidos, tem-se a tabela 12 e as Figuras 83 e 84. Na tabela 12 , o experimento 1 (em vermelho) é o padrão ao qual foi comparado todos os outros experimentos. Nos demais experimentos o item em vermelho foi o variado em relação ao experimento padrão.

Tabela 12 - Parametrização da liberação controlada eletroquimicamente de safranina.

\begin{tabular}{|c|c|c|c|c|c|c|}
\hline experimento & Carga/ C & $\mathbf{p H}$ & hidrogel & $\begin{array}{c}V_{\text {red }} / \\
\text { nmol.cm } \\
-3 \\
\mathrm{~min}^{-1}\end{array}$ & $\begin{array}{c}V_{\text {oxi }} / \\
\text { nmol.cm } \\
-3 \\
\text {. } \mathrm{min}^{-1}\end{array}$ & $\phi$ \\
\hline 1 & 8,5 & 1 & 1 & 1,3 & 13,2 & 8,92 \\
\hline 2 & 4,0 & 1 & 1 & 3,7 & 11,6 & 2,16 \\
\hline 3 & 17,0 & 1 & 1 & 0,9 & 6,1 & 5,78 \\
\hline 4 & 8,5 & 1 & 2 & 0,3 & 12,4 & 37,39 \\
\hline 5 & 7,5 & 1 & 11 & 4,2 & 10,4 & 1,48 \\
\hline 6 & 8,5 & 0 & 1 & --- & --- & --- \\
\hline 7 & 8,5 & 7 & 1 & --. & --- & --- \\
\hline 8 & 8,5 & 3,2 & 1 & --- & --- & --- \\
\hline
\end{tabular}

A Figura 83 faz a ligação entre todo o material apresentado no apêndice e a eficiência do controle eletroquímico, justificando assim todo o estudo dedicado aos diferentes hidrogéis sintetizados e deixa em aberto a otimização deste parâmetro (tamanho de poro), podendo hidrogéis com maiores poros serem mais eficientes. A distribuição da polianilina dentro das diferentes matrizes de poliacrilamida pode ajudar a compreender este resultado. A melhor eficiência do controle eletroquímico $(\phi)$, foi obtida com um compósito formado a partir de um hidrogel 2, e a tendência observada 
para $\phi$ em relação ao tamanho de poro dos hidrogéis $(\xi)$, é de aumentar conforme se aumenta $\xi$.

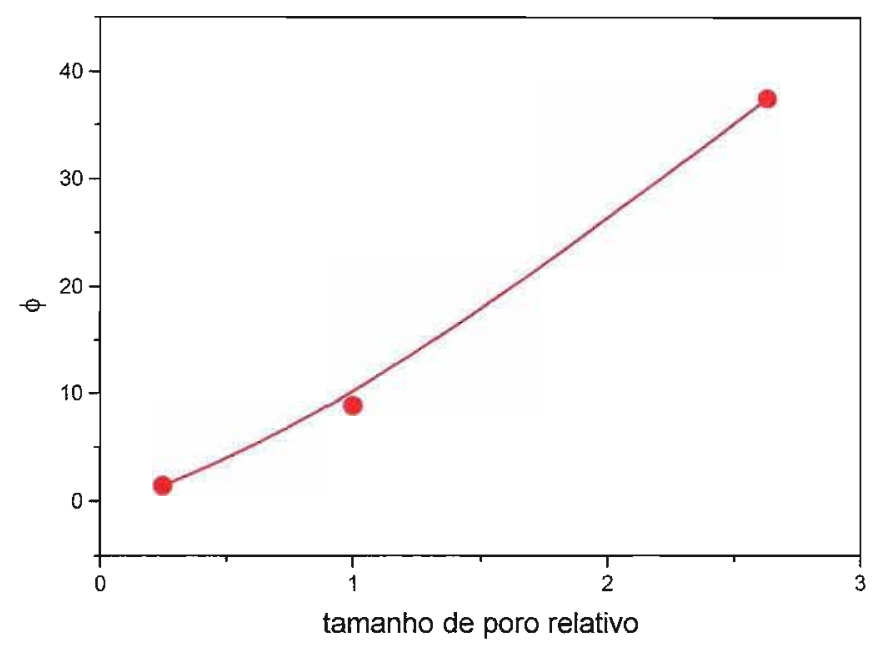

Figura 83 - $\phi \times$ tamanho de poro.

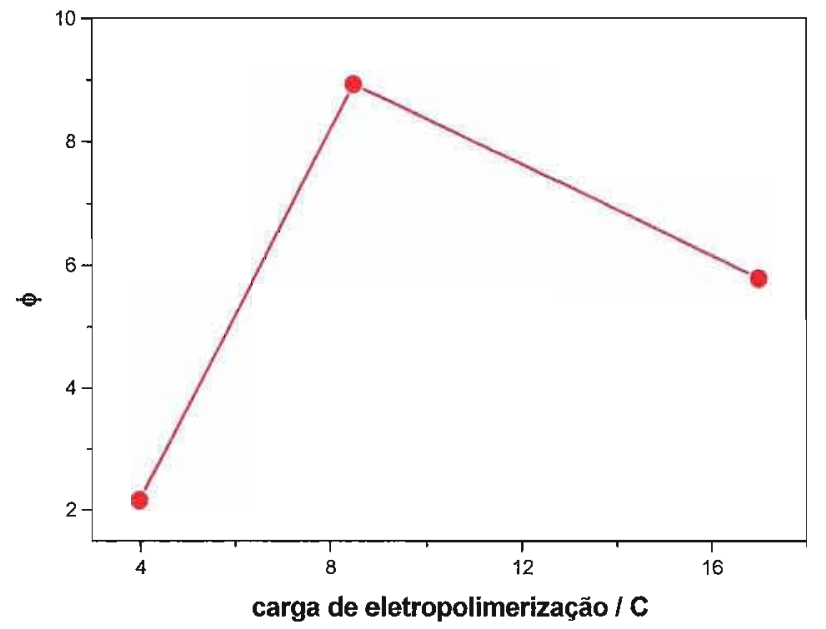

Figura $84-\phi \times$ quantidade de polianilina. Os compósitos foram formados com o hidrogel 1.

Se maiores tamanhos de poros resultam num controle eletroquímico mais eficiente, e se o controle eletroquímico está baseado na mudança de volume do polímero condutor dentro dos poros da poliacrilamida, pode-se propor a seguinte associação: poros maiores permitem um maior crescimento do polímero condutor no sentido perpendicular ao canal, ou seja, permite uma maior sobreposição de camadas de polianilina dentro do poro e quanto maior quantidade de polianilina no interior do poro, 
maior a variação de volume que se pode obter devido à mudança de estado de oxidação do polímero condutor e, portanto uma maior resposta eletroquímica será obtida.

Na Figura 84 verifica-se que para o hidrogel 1 já se encontrou um ótimo de quantidade de polímero condutor em relação à resposta eletroquímica que pode ser obtida.

Com a finalidade de se generalizar os bons resultados obtidos, ou seja, para que sejam válidos na aplicação de outras moléculas (fármacos de fato), e fundamentar as discussões já apresentadas quanto à eficiência do controle eletroquímico, a próxima seção mostra o estudo do mecanismo de atuação deste tipo de sistema.

\subsubsection{3 - Atuação de redes condutoras semi-interpenetrantes de poliacrilamida / polianilina}

Frente aos resultados obtidos na liberação controlada de safranina, poder-se-ia, num primeiro momento, dizer simplesmente que a eletroatividade da polianilina, ou seja, que a mudança de estado de oxidação do polímero condutor é responsável pelo controle eletroquímico da liberação, porém, indo mais além, pode se indagar se o controle eletroquímico é obtido diretamente pela compensação de carga na matriz polimérica, uma vez que a molécula-modelo testada foi um cátion, ou se vem de um efeito secundário da compensação de cargas, que é a mudança de volume do polímero condutor no interior do hidrogel. Neste trabalho, inicialmente, foi proposto que a propriedade de músculo artificial seria a responsável pelo funcionamento do sistema, permitindo assim estudos e aplicações futuras mais amplas no sentido de não se restringir mais o sistema a drogas ou moléculas pequenas e carregadas. No sentido de elucidar o mecanismo de atuação destes compósitos, comprovando ou não a proposição inicial, foram realizados dois experimentos: no primeiro verificou-se a mudança de tamanho "in situ" do compósito frente a pulsos de potencial. No segundo, demonstrouse o efeito do estado de oxidação do compósito na liberação de uma molécula-modelo neutra. 
4.3.7.3.1 - Propriedade de músculo artificial das redes condutoras semi-interpenetrantes de poliacrilamida / polianilina

Imagens de microscopia óptica mostraram que o compósito de poliacrilamida / polianilina apresenta notável alteração de tamanho com a mudança de seu estado de oxidação. Tal resultado é extremamente importante para a compreensão do mecanismo de atuação deste sistema, uma vez que é uma evidência direta do controle eletroquímico do volume do compósito. A Figura $85 \mathrm{~A}$ mostra uma micrografia da superfície do compósito gerada por um corte longitudinal. A região mais clara é parte da estrutura do compósito (uma saliência gerada pelo corte) cujo movimento foi acompanhado em função potencial aplicado ao sistema. Inicialmente o compósito foi polarizado a $0,5 \mathrm{~V}$, e a imagem da Figura 85A foi adquirida depois da estabilização (fim da movimentação) do compósito; a seguir foi aplicado um pulso de $-0,5 \mathrm{~V}$ e verificada a variação de volume do compósito através da movimentação da região mais clara da micrografia. $\mathrm{Na}$ Figura 85B tem-se então a posição final do compósito.

Nas Figuras $85 \mathrm{~A}$ e $85 \mathrm{~B}$, a estrutura que teve seu movimento acompanhado com a mudança do potencial do sistema está marcada com uma linha branca. Foi observado que durante a redução do compósito, o mesmo se contraía (movimentação da estrutura da esquerda para a direita em relação ao centro do compósito) e se expandia durante a oxidação (movimentação da estrutura da direita para a esquerda em relação ao centro), tal comportamento foi reprodutível em diversos pontos do compósito analisado. Também foi verificado que em repetidos ciclos de potencial $(0,5 /-0,5 \mathrm{~V})$ as estruturas em observação sempre alcançavam o mesmo ponto inicial e final. Como a intenção inicial destes experimentos era comprovar a propriedade de músculo artificial dos compósitos, não foi extraído nenhum dado quantitativo a respeito da porcentagem de variação de tamanho, nem da cinética da movimentação do compósito, porém qualitativamente pode-se dizer que a alteração de tamanho é rápida, por exemplo, o deslocamento visto nas Figuras $85 \mathrm{~A}$ e $\mathrm{B}$, que foi de aproximadamente $16 \mu \mathrm{m}$, ocorreu em menos de 30 s. 


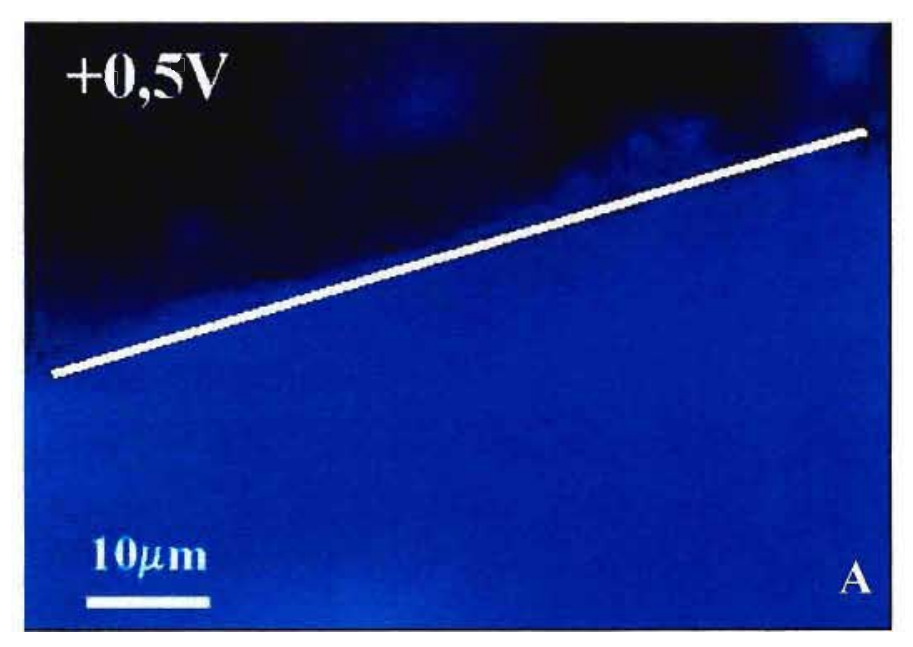

BIBLIOTECA INSTITUTO DE QUINICA

Unwersidade de São Pauto

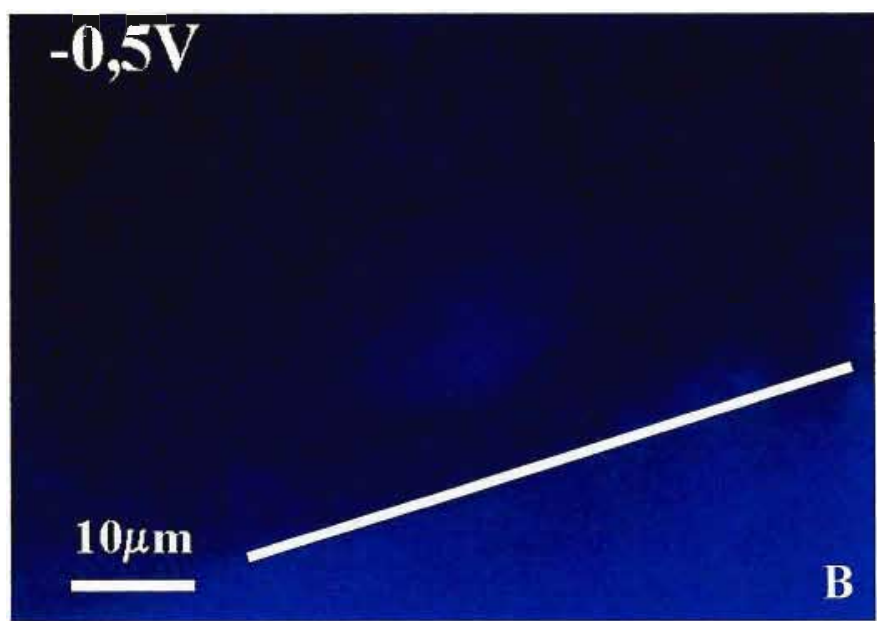

Figura 85 - Imagens de microscopia óptica da superfície de um compósito de poliacrilamida / polianilina. A - compósito oxidado $(0,5 \mathrm{~V})$. B - compósito reduzido $(-0,5 \mathrm{~V})$. Notar que a região mais clara da superfície se deslocou diagonalmente na figura conforme se reduz o compósito, este movimento corresponde à contração da rede condutora semi-interpenetrante.

4.3.7.3.2 - Liberação de pirocatecol a partir de redes condutoras semi-interpenetrantes de poliacrilamida / polianilina

Considerando que o mecanismo de atuação dos compósitos no controle eletroquímico da liberação de moléculas, tem como componente predominante a mudança de volume do polímero condutor dentro dos canais do hidrogel, $\phi$ (eficiência do controle eletroquímico) independerá (ou dependerá em pouca extensão) da carga da molécula testada. Por outro lado, se o aumento da velocidade de liberação de safranina (um cátion), observado quando se oxida o compósito, for majoritariamente uma resposta 
à repulsão entre as cargas positivas da molécula e da polianilina, ao testar o compósito com uma molécula neutra ou negativa, essa resposta não mais será verificada. Assim, procurou-se uma molécula-modelo para os testes de liberação que tivesse tamanho semelhante ao da safranina, fosse solúvel em água, tivesse espectro de absorção na região do visível e que fosse neutra ou aniônica em meio ácido. Uma molécula que cumpri todos os requisitos citados acima é o pirocatecol violeta, mostrado na Figura 86, que possui três hidrogênios ácidos, sendo que o mais ácido deles, o hidrogênio ligado ao grupo sulfonato, possui $\mathrm{pKa}=1^{78}$, portanto numa liberação ocorrendo em ácido clorídrico $0,1 \mathrm{~mol} . \mathrm{L}^{-1}(\mathrm{pH}=1)$, o pirocatecol está presente tanto como molécula neutra, como ânion sulfonato.

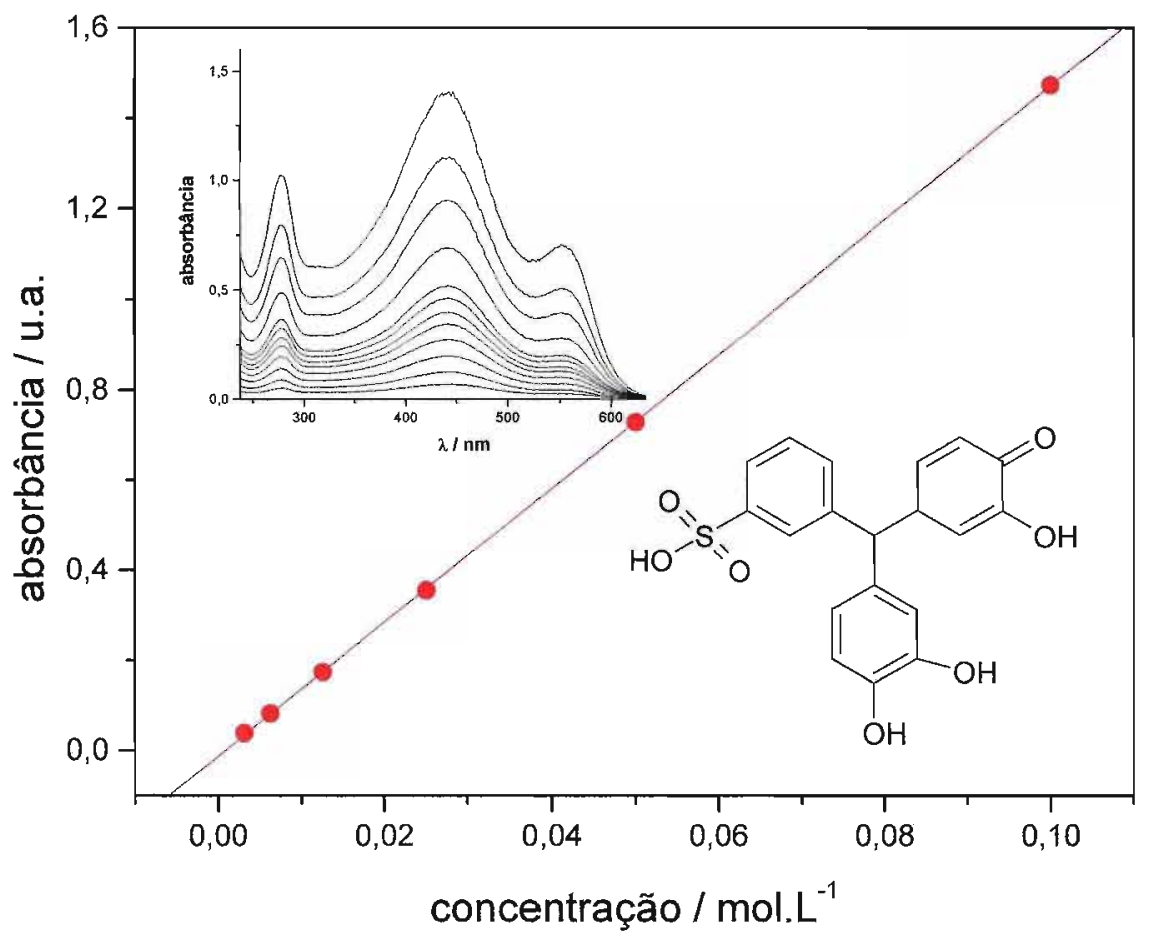

Figura 86 - Curva analítica do pirocatecol em solução aquosa de $\mathrm{HCl}$ 0,1 mol.L ${ }^{-1}$. equação da reta: Absorbância $(441 \mathrm{~nm})=-0,012+14,824 x$ concentração. Detalhe: espectros UV-VIS de soluções aquosas de $\mathrm{HCl} 0,1 \mathrm{~mol}^{-1} \mathrm{~L}^{-1}$ de diferentes concentrações de pirocatecol e estrutura do pirocatecol violeta (massa molar $=386,38 \mathrm{~g} \cdot \mathrm{mol} \cdot \mathrm{L}^{-1}$ ).

A curva analítica e alguns espectros do pirocatecol em solução de $\mathrm{HCl}$ 0,1mol.L $\mathrm{L}^{-1}$ são mostrados também na Figura 86. Na Figura 87, verifica-se a eletroatividade do pirocatecol sobre polianilina, tal resultado é importante na escolha dos potenciais que podem ser utilizados nos testes de liberação controlada sem modificar o pirocatecol. Como pode ser visto (Figura 87), o pirocatecol sofre oxidação 
sobre a polianilina a partir de potenciais maiores que $\sim 0,45 \mathrm{~V}$, portanto nos testes de liberação controlada o potencial de oxidação tem que ser inferior a $0,45 \mathrm{~V}$. Para a liberação controlada de pirocatecol determinou-se então o potencial de $-0,1 \mathrm{~V}$ para o estado reduzido e $0,4 \mathrm{~V}$ para se obter o estado oxidado do compósito. $\mathrm{O}$ objetivo deste experimento é a comparação da eficiência do controle eletroquímico na liberação de safranina e de pirocatecol, portanto as condições de ambos os experimentos têm que ser iguais, e como não havia ainda curvas de liberação de safranina nos potenciais de $-0,1 \mathrm{~V}$ / 0,4V, a Figura 88 traz este experimento.

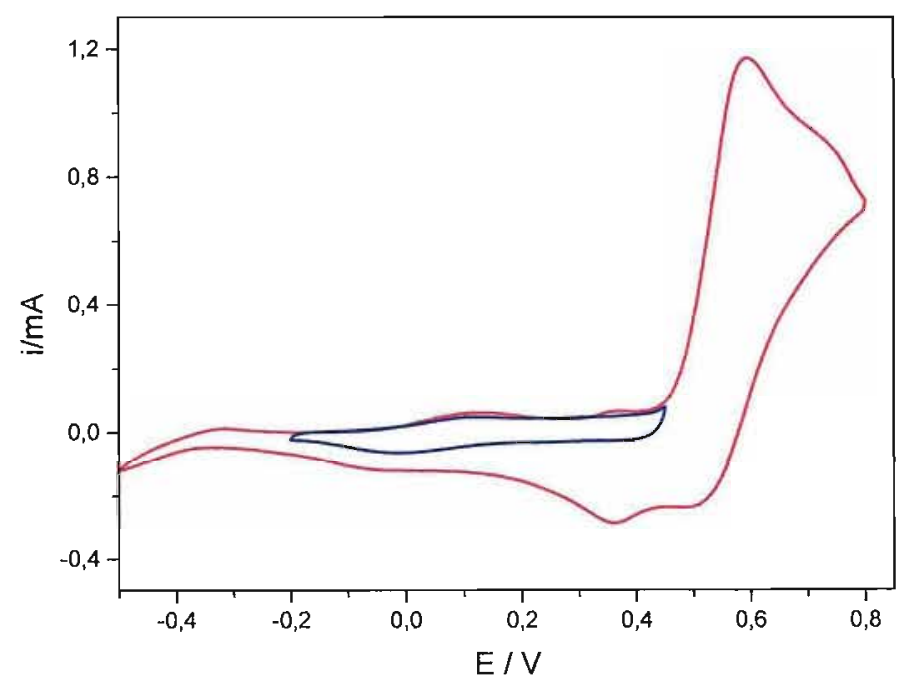

Figura 87 - Voltamogramas de solução aquosa de $\mathrm{HCl}$ 0,1mol.L ${ }^{-1}+$ pirocatecol 0,1 mol. $L^{-1}$. Eletrodo trabalho: disco de platina recoberto com filme de polianilina. Em vermelho: janela de potencial aonde o pirocatecol sofre processo redox sobre a polianilina. Em azul: faixa de potencial aonde é possível oxidar/reduzir a polianilina sem modificar o pirocatecol. $\mathrm{v}=50 \mathrm{mVs}^{-1}$. 


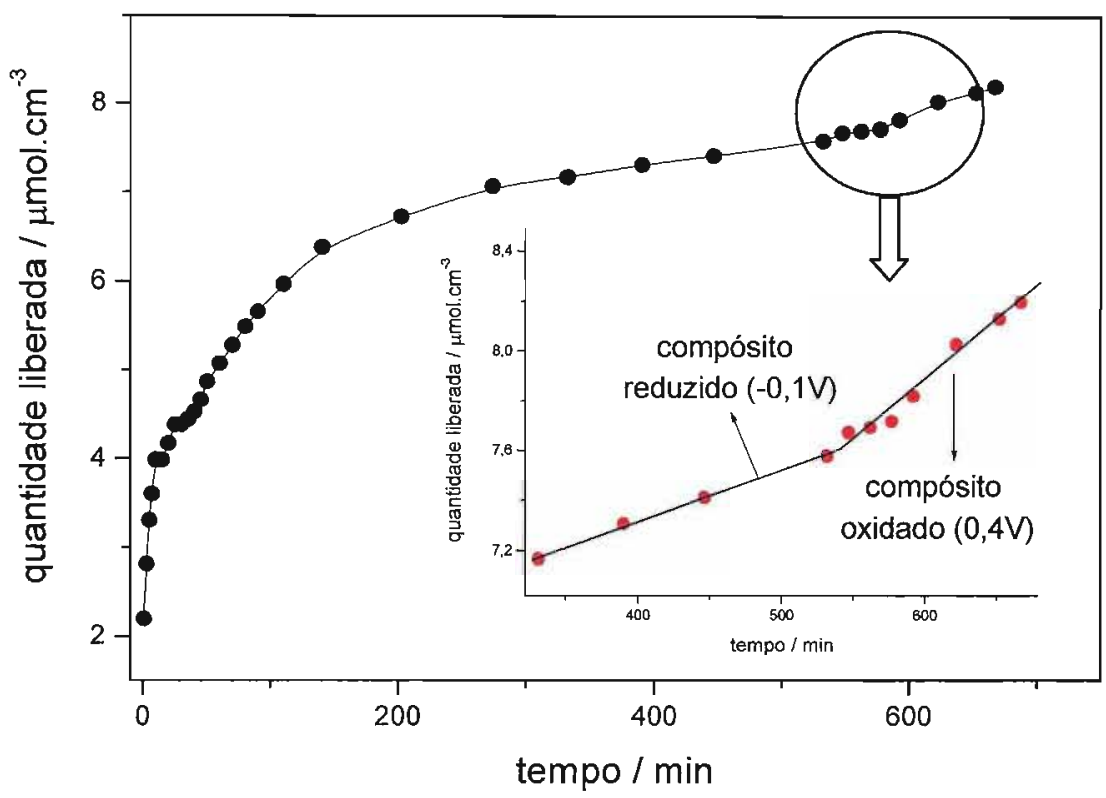

Figura 88 - Curva de liberação de safranina em solução aquosa de $\mathrm{HCl} 0,1 \mathrm{~mol} \cdot \mathrm{L}^{-1}$ a partir de um compósito de poliacrilamida / polianilina primeiramente reduzido e depois oxidado. Detalhe: ampliação do gráfico na região na região próxima à mudança de potencial.

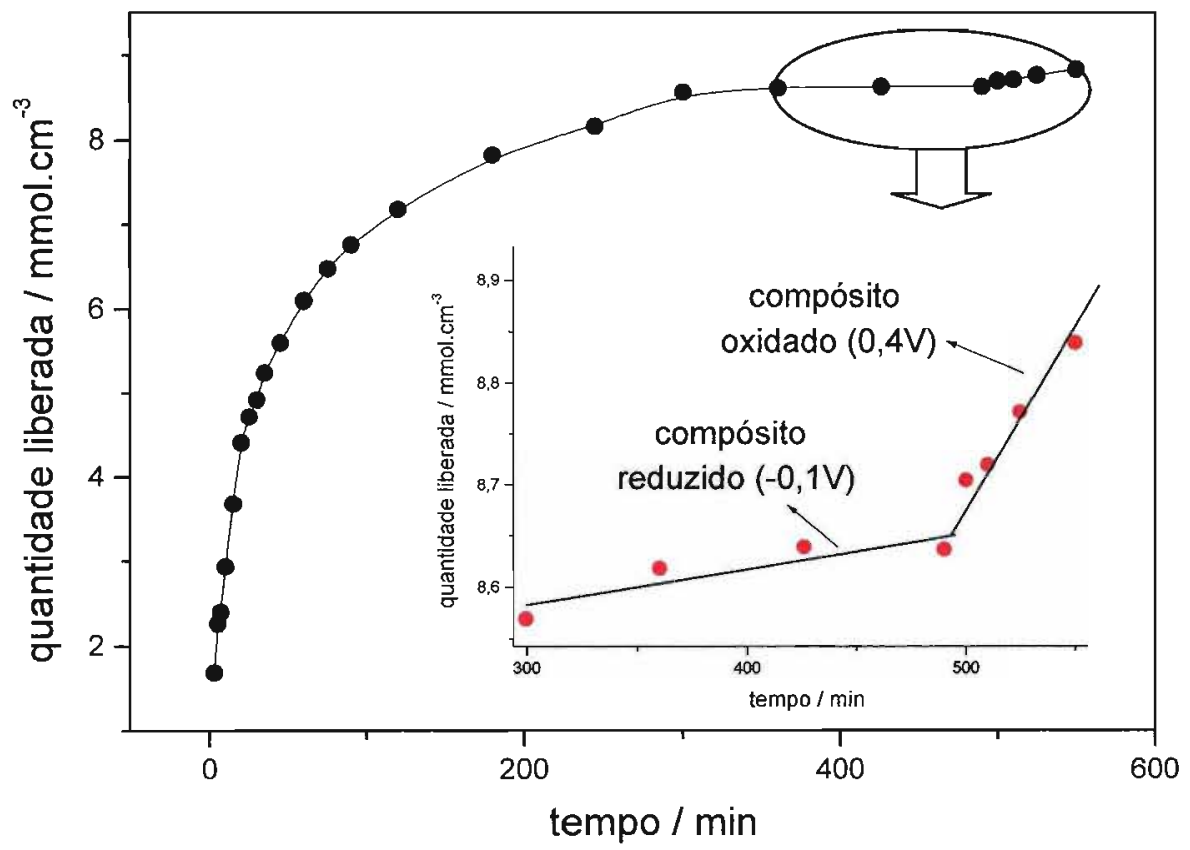

Figura 89 - Curva de liberação de pirocatecol em solução aquosa de $\mathrm{HCl}$ 0,1mol. $\mathrm{L}^{-1}$ a partir de um compósito de poliacrilamida / polianilina primeiramente reduzido e depois oxidado. Detalhe: ampliação do gráfico na região na região próxima à mudança de potencial. 
Para os dois experimentos de liberação controlada (de safranina e de pirocatecol) nos potenciais de $-0,1 / 0,4 \mathrm{~V}$ foi utilizado o compósito que apresentou o melhor valor de $\phi$ (seção 4.3.7.2), ou seja, o compósito formado pela eletropolimerização de anilina no interior de um hidrogel 2. A carga de polimerização foi de 8,5 C. A liberação controlada de pirocatecol em solução aquosa de $\mathrm{HCl} 0,1 \mathrm{~mol} . \mathrm{L}^{-1}$ é mostrada na Figura 89. Através de valores de $\phi$ foi possível comparar as duas liberações. Para o cálculo de $\phi$ considerou-se como lineares as regiões próximas à mudança de potencial do sistema, e os coeficientes angulares de cada reta (detalhes das figuras 88 e 89 ) foram considerados como as velocidades de liberação da molécula-modelo a partir do sistema reduzido $\left(\mathrm{V}_{\text {red }}\right)$ e do sistema oxidado $\left(\mathrm{V}_{\text {oxi }}\right)$. Os resultados são mostrados na tabela 13.

Tabela 13 - Valores de velocidade de liberação de safranina e pirocatecol a partir de compósitos de poliacrilamida/ polianilina nos estados reduzido e oxidado.

\begin{tabular}{|c|c|c|c|}
\hline Liberação controlada de & $\mathrm{V}_{\text {red }} / \mathrm{mol} \mathrm{cm}^{-3} \cdot \mathrm{min}^{-1}$ & $\mathrm{~V}_{\text {oxi }} / \mathrm{mol} \mathrm{cm}^{-3} \cdot \mathrm{min}^{-1}$ & $\phi^{\mathrm{c}}$ \\
\hline Safranina $^{\text {at }}$ & $0,3 \cdot 10^{-9}$ & $12,4 \cdot 10^{-9}$ & 37,4 \\
\hline Safranina $^{b}$ & $2,7.10^{-9}$ & $3,8 \cdot 10^{-9}$ & 0,4 \\
\hline Pirocatecol $^{b}$ & $3,5 \cdot 10^{-7}$ & $3,2.10^{-6}$ & 8,2 \\
\hline
\end{tabular}

Os dados mostrados na tabela 13 reforçam a proposta do mecanismo de liberação controlada por alteração de volume no interior dos poros do compósito uma vez que, na faixa de potencial estudada, o controle eletroquímico na liberação de pirocatecol foi mais efetivo que na liberação de safranina. Este resultado mostrou que mesmo o pirocatecol sendo um ânion / molécula neutra no pH da solução de liberação, sua saída do compósito é acelerada quando este está oxidado, excluindo assim a interação entre as cargas da molécula e do compósito como maior responsável pelo mecanismo de liberação eletroquímica. Lembrando que no estado oxidado o compósito apresenta maior volume, portando menor espaço no interior dos poros, a maior velocidade de liberação do pirocatecol no estado oxidado do que no estado reduzido do compósito, só pode ser explicado em termos do bombeamento de suas moléculas para o exterior do compósito. 
Outro fator importante que pode ser extraído da tabela 13 é o fato de que o controle eletroquímico é maior na liberação do pirocatecol do que na liberação de safranina. Pode-se explicar tal fato de maneira simples, considerando apenas que a safranina interage mais com a rede condutora semi-interpenetrante do que o pirocatecol, sendo este último mais suscetível ao controle eletroquímico. Duas evidências indiretas para a maior interação da safranina com o compósito podem ser relatadas: i. já foi mostrado (seção 4.3.7.1.1) que a liberação em $\mathrm{pH}=0$ foi menos efetiva do que em $\mathrm{pH}=1$ ao contrário do que se esperava devido ao comportamento da eletroatividade da polianilina em diferentes pHs. A explicação para tal fato foi que a safranina em $\mathrm{pHs}$ mais baixos está mais protonada, e, portanto, mais capaz de interagir, por ponte de hidrogênio, com o compósito. Assim, pode-se afirmar que num mesmo $\mathrm{pH}$, a safranina interage mais com o compósito que o pirocatecol. ii. Em experimentos iguais (mesmo compósito, forma de carregamento, condições de liberação), há uma liberação de uma quantidade muito maior (aproximadamente mil vezes maior) de pirocatecol do que de safranina, indicando também que o pirocatecol interage muito menos com o compósito, podendo assim ser liberado com maior facilidade em relação à safranina.

Por fim, da tabela 13 ainda pode ser extraído mais um importante resultado: a comparação da liberação de safranina em diferentes potenciais. A extensão do controle eletroquímico na liberação depende do potencial aplicado ao sistema de modo esperado em relação à eletroatividade do polímero condutor. Dessa forma, $\phi$ para a liberação ocorrendo entre $-0,2$ e $+0,6 \mathrm{~V}$ é igual a 37,4 e para a liberação ocorrendo entre $-0,1$ e $+0,4 \mathrm{~V}, \phi=0,4$, no primeiro caso, a variação do estado de oxidação do compósito é maior, ocasionando uma variação de volume também maior e conseqüentemente se obtém um maior valor de $\phi$.

4.3.7.3.3 - Mecanismo de atuação das redes condutoras semi-interpenetrantes em sistemas de liberação controlada

Com os experimentos propostos nas seções 4.3.7.3.1 e 4.3.7.3.2 conseguiu-se provar que o mecanismo de liberação controlada eletroquimicamente é baseado na mudança de volume de compósito com a mudança do seu estado de oxidação: o compósito reduzido tem um estado de menor volume, ou seja, menor volume vazio que pode ajudar a reter, ou seja, diminuir a velocidade de liberação de moléculas 
incorporadas nos poros destes compósitos. Ao se oxidar a rede, a entrada de ânions (cloreto neste caso) e água na matriz polimérica para se compensar a carga positiva gerada na polianilina, faz com que o volume do compósito aumente (o aumento de volume da própria polianilina oxidada também ajuda neste efeito), e a fração polimérica do compósito se expande, os poros da rede também devem se expandir permitindo assim uma liberação mais rápida das moléculas-modelo ainda incorporadas na matriz. Um esquema deste mecanismo pode ser visto na Figura 90. É importante notar que a eficiência deste mecanismo proposto vai depender da elasticidade da matriz hospedeira: esta tem que ser capaz de acompanhar as alterações de volume provocada pela mudança de estado do polímero condutor. Neste sentido os hidrogéis são excelentes materiais, pois possuem uma estrutura tridimensional que facilmente pode convertida entre dois estados conformacionais diferentes. A utilização de matrizes hospedeiras constituídas de materiais rígidos mecanicamente, como silício poroso, por exemplo, poderia fornecer um material mais fácil de caracterizar com poros mais regulares e melhor definidos, porém poderia não funcionar como as redes condutoras semi-interpenetrantes de polímero condutor / hidrogel, ou funcionar através de um mecanismo completamente diferente.

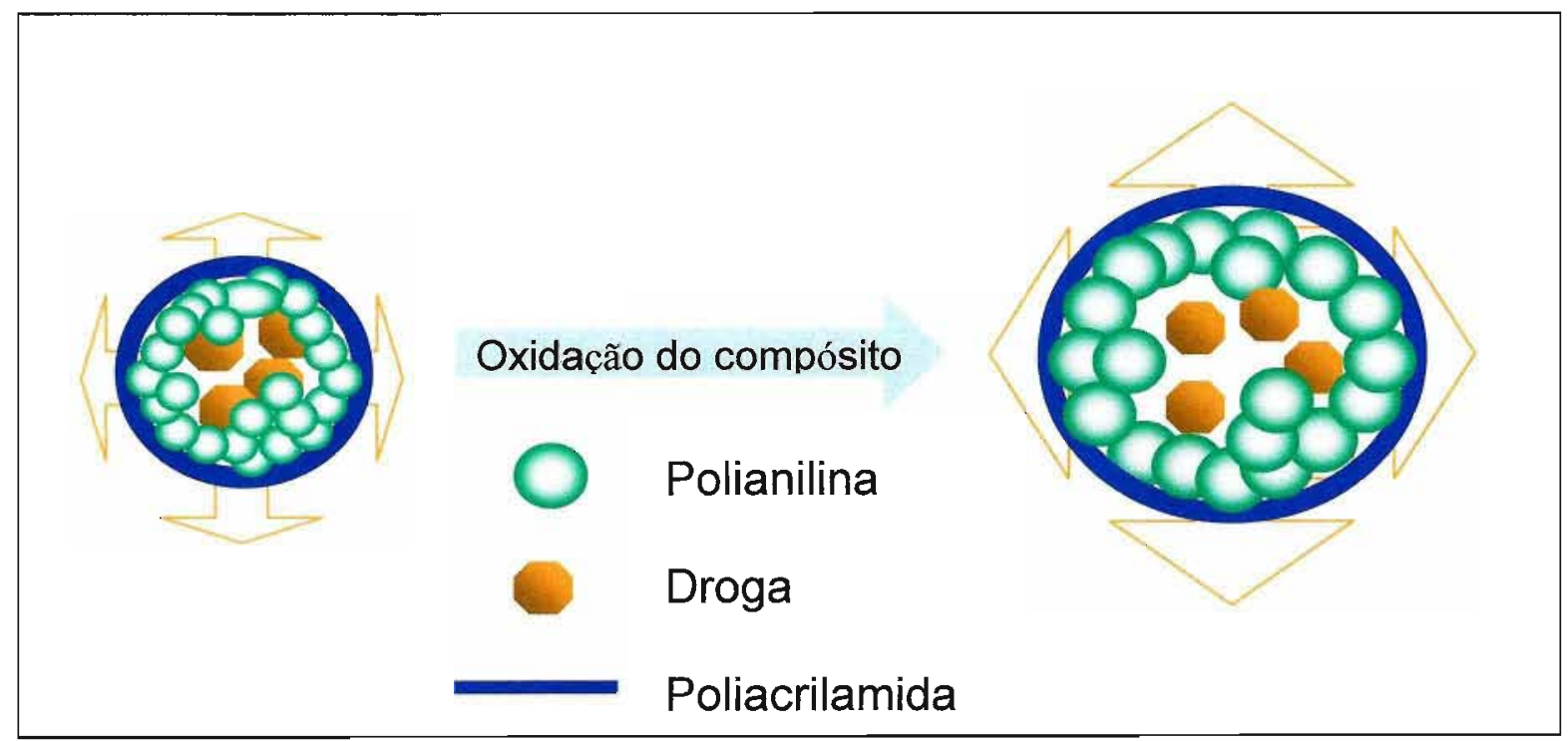

Figura 90 - Esquema do mecanismo de atuação de redes condutoras semiinterpenetrantes de polianilina / poliacrilamida. Na direita da figura tem-se a representação de poro da matriz parcialmente preenchido com o polímero condutor e com a droga quando o compósito está reduzido. À esquerda, o mesmo poro depois da oxidação do compósito. As setas ao redor do hidrogel representam a liberação da droga e o tamanho da seta representa a velocidade de liberação. Note que neste mecanismo, a natureza elétrica da droga não importa, esta poderá ter sua velocidade de liberação controlada eletroquimicamente independente de ser catiônica, aniônica ou neutra. 


\subsubsection{2 - Liberação controlada de tetraciclina}

Uma vez caracterizada a rede condutora semi-interpenetrante de polianilina / poliacrilamida, proposto o mecanismo de atuação deste sistema da Geração II, finalizase esta tese com testes de liberação controlada de tetraciclina. Algumas propriedades químicas deste conhecido antibiótico podem ser vistas na tabela 14. Destaca-se que esta molécula é ligeiramente maior que a safranina ou que o pirocatecol violeta testados anteriormente e também possui uma solubilidade limitada em água, tais fatores já levam os experimentos de liberação controlada para um patamar mais próximo da realidade (e mais distantes da idealidade, como foi o caso dos testes com os corantes). A Figura 91 mostra a estrutura da tetraciclina e o voltamograma de um filme de polianilina sintetizado por voltametria cíclica $\left(-0,2-0,75 \mathrm{~V}, 50 \mathrm{mVs}^{-1}\right)$ em solução contendo $\mathrm{HCl}$ 1,0mol. $\mathrm{L}^{-1}$ e $0,5 \mathrm{mmol} . \mathrm{L}^{-1}$ de tetraciclina, como se tem somente perfil voltamétrico esperado para o polímero condutor, pode-se assegurar que a droga testada não será modificada durante o processo de liberação controlada.

Tabela 14 - Propriedades da tetraciclina.

\begin{tabular}{cc}
\hline \multicolumn{2}{c}{ Tetraciclina } \\
\hline Massa molar/g.mol $l^{-1}$ & 444,45 \\
Solubilidade/mg. $L^{-1}$ & 231 \\
$p k_{a}$ & 3,3 \\
$\lambda_{\text {móx }}$ nm & 356 \\
Curva analítica & $\mathrm{y}=0,0014+13.287,14 * \mathrm{x}$ \\
\hline
\end{tabular}

* curva determinada utilizando a absorção em 356nm. $\mathrm{Y}=$ absorbância $\mathrm{e} x=$ concentração molar. 


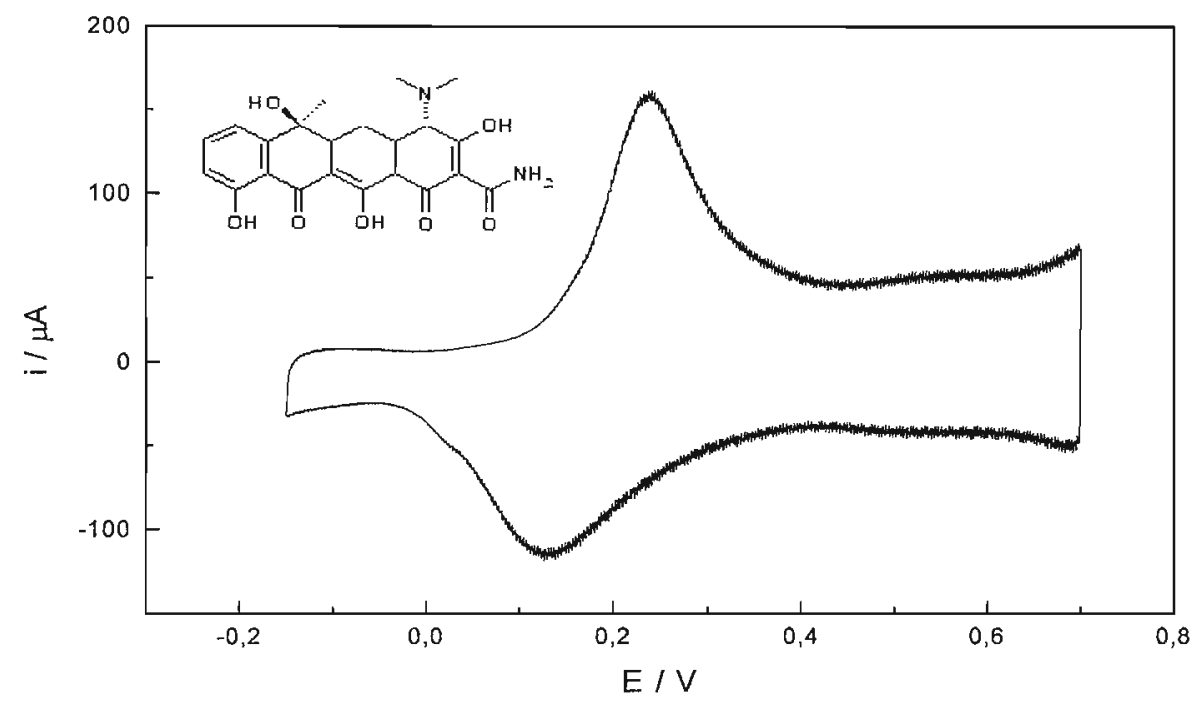

Figura 91 - Voltametria cíclica de um filme de polianilina em solução aquosa contendo HCl $1,0 \mathrm{~mol} . \mathrm{L}^{-1}$ e tetraciclina. $\mathrm{v}=50 \mathrm{mV} . \mathrm{s}^{-1}$. No detalhe, estrutura da tetraciclina.

Inicialmente, procedeu-se o carregamento intumescendo-se um compósito seco em uma solução aquosa $0,5 \mathrm{mmol} \cdot \mathrm{L}^{-1}$ de tetraciclina (limite de concentração devido à solubilidade da droga) e realizou-se a liberação em $\mathrm{HCl}$ 0,1mol. $\mathrm{L}^{-1}$. A Figura 92 traz a curva de liberação controlada, onde pode ser verificada a liberação controlada por difusão no inicio do experimento e o controle eletroquímico proporcionado pela oxidação do compósito. Testes posteriores mostraram que a curva de liberação não era reprodutivel, a Figura 93 mostra alguns exemplos dos testes efetuados. Apesar de ter sido verificado o controle eletroquímico nas curvas B e C (aumento na velocidade de liberação após oxidação do compósito), tanto a forma da curva quanto a quantidade liberada diferiram muito da primeira curva obtida (curva A).

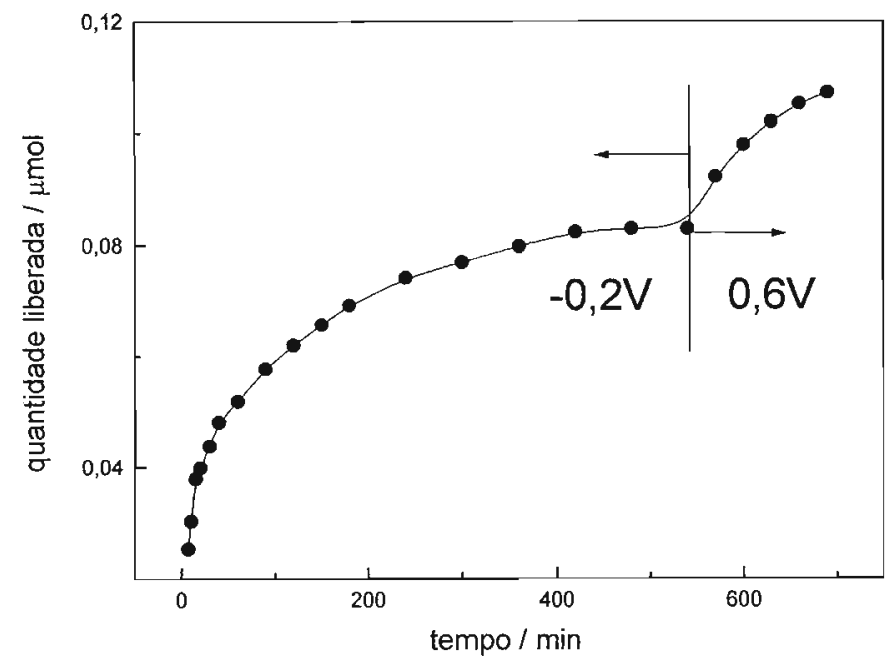

Figura 92 - Curva de liberação de tetraciclina em $20 \mathrm{~mL}$ de solução aquosa de $\mathrm{HCl}$ $0,1 \mathrm{~mol} . \mathrm{L}^{-1}$. 


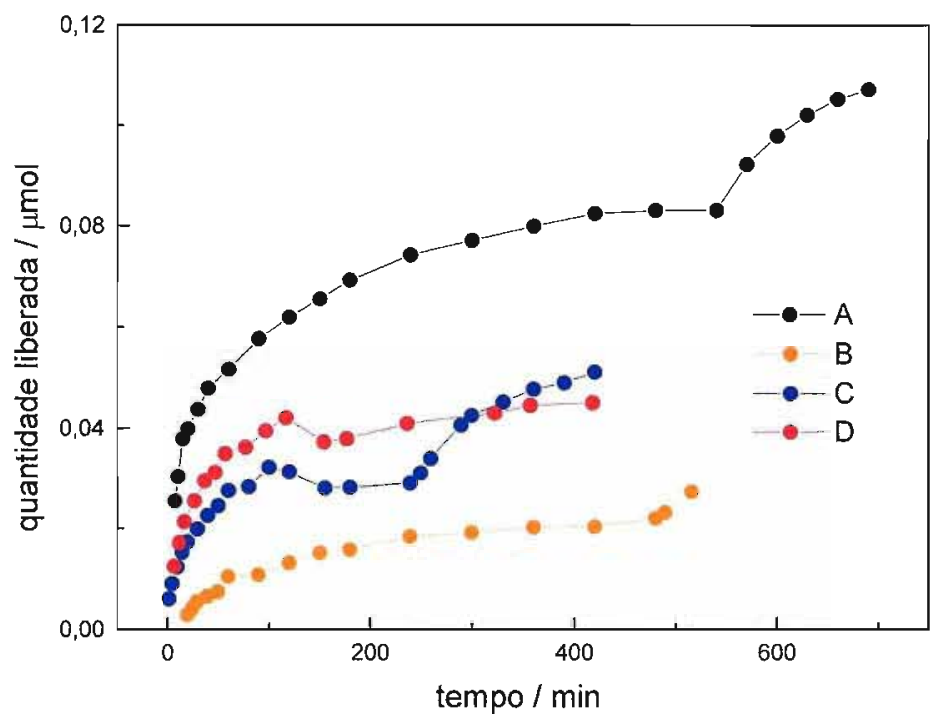

Figura 93 - Curvas de liberação de tetraciclina em $20 \mathrm{~mL}$ de solução aquosa de $\mathrm{HCl}$ 0,1mol.L $\mathrm{L}^{-1}$. A - curva da figura 92. B - compósito inicialmente reduzido $(-0,2 \mathrm{~V})$ e posteriormente oxidado $(0,6 \mathrm{~V})$. C - idem B. D - liberação espontânea (a potencial de circuito aberto).

A causa da não reprodutibilidade do sistema pode ser atribuída à forma como a droga é incorporada: ao se secar o compósito ao ar (temperatura ambiente), há a possibilidade de ocorrer o entrecruzamento das cadeias de polianilina como mostrado na Figura 94 (adaptada da referência 15), o que resultaria num compósito com estrutura mais fechada (menor tamanho de poros) e menor porosidade. A menor porosidade pode ser visualmente verificada, uma vez que depois de seco, ao se intumescer novamente o compósito, este atingiu um volume de equilíbrio menor do que o do estado intumescido anterior. Nas curvas de liberação, o efeito da presença das ligações cruzadas pode ser verificado pela diminuição da quantidade de tetraciclina incorporada/liberada nos casos $\mathrm{B}, \mathrm{C}$ e D quando comparada com a quantidade incorporada no experimento A. Neste ponto é importante ressaltar que o tempo de secagem do compósito era no mínimo de quatro horas, porém podendo chegar a tempos superiores, e para o experimento $\mathrm{A}$, o tempo de secagem foi o múnimo, produzindo assim um compósito com cadeias de polianilina menos reticuladas. Também é possível verificar o efeito da reticulação nos perfis de liberação pela diversidade de resultados obtidos, uma vez que a reticulação é um processo aleatório inter- e intracadeia. 


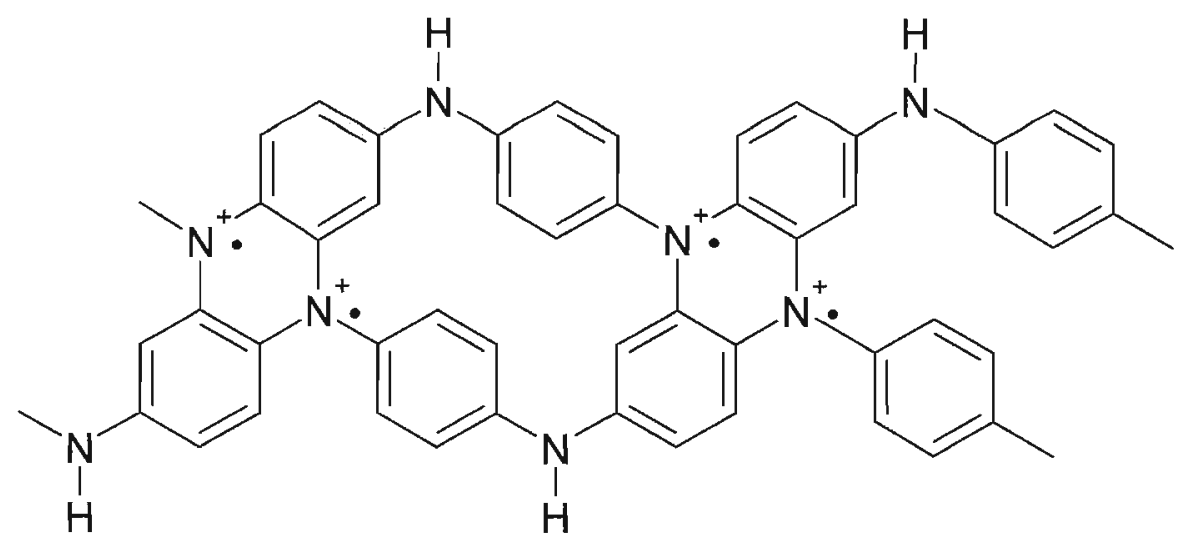

Figura 94 - Esquema de cadeias de poliesmeraldina base reticuladas. Adaptado da referência 15.

A partir deste ponto optou-se por outra forma de carregamento do compósito. Após o processo de extração em água, o compósito foi colocado em $5 \mathrm{ml}$ de solução aquosa $0,5 \mathrm{mmol} . \mathrm{L}^{-1}$ de tetraciclina, sem ser previamente seco. Com este procedimento foram obtidas todas as outras curvas de liberação de forma reprodutível, possibilitando assim a parametrização do sistema polianilina/poliacrilamida/tetraciclina. A Figura 95 mostra a curva de liberação espontânea (a potencial de circuito aberto) e também uma curva de liberação controlada (compósito inicialmente reduzido e depois oxidado). Como esperado em função do mecanismo de atuação do compósito, a liberação a ECA, ou seja com a rede no seu estado oxidado de equilíbrio é mais rápida, quando comparada com a liberação a partir de outra matriz reduzida. Ao se oxidar o compósito, a velocidade de liberação aumenta e a quantidade de tetraciclina liberada logo atingi o valor obtido na liberação espontânea (no mesmo tempo). A Figura 96 traz as mesmas duas curvas, porém desta vez se mostra a porcentagem de tetraciclina liberada, normalizando a ordenada e tornando a comparação significativa. É importante destacar que não há diferença entre as duas curvas nos dois gráficos, isto porque a quantidade de tetraciclina incorporada nos dois compósitos foi praticamente a mesma (a quantidade exata será mostrada a seguir na tabela 15), mostrando que de fato esta metodologia pode fornecer um conjunto de dados reprodutíveis. 


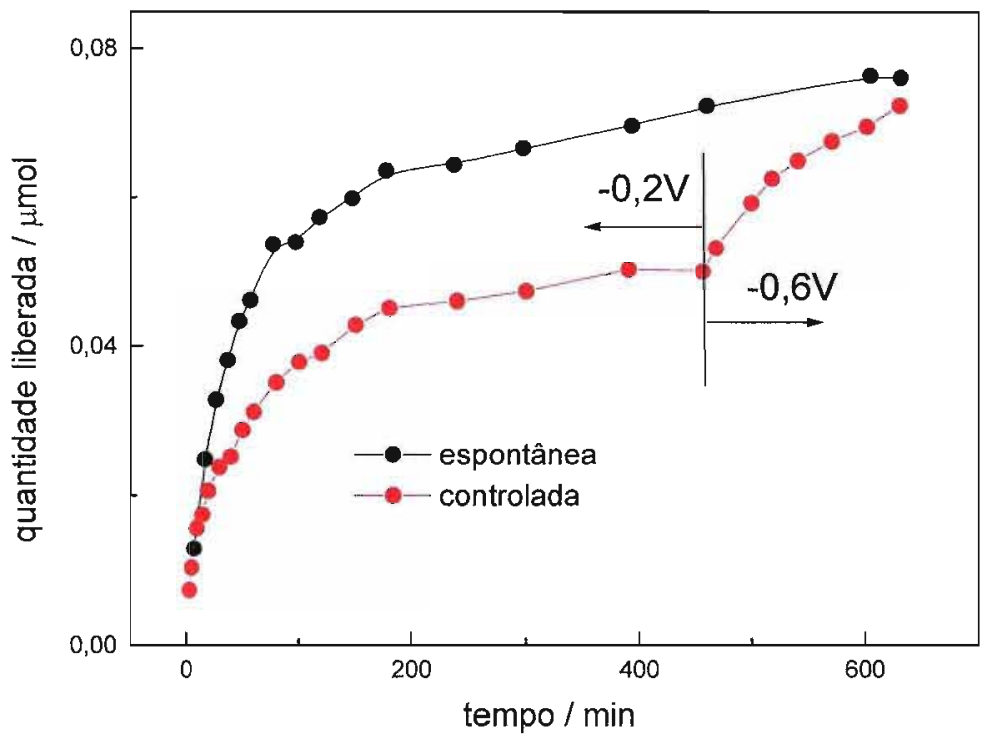

Figura 95 - Curvas de liberação de tetraciclina em $20 \mathrm{~mL}$ de solução aquosa de $\mathrm{HCl}$ 0,1 mol. $L^{-1}$. Observação: cada curva foi obtida de um compósito diferente.

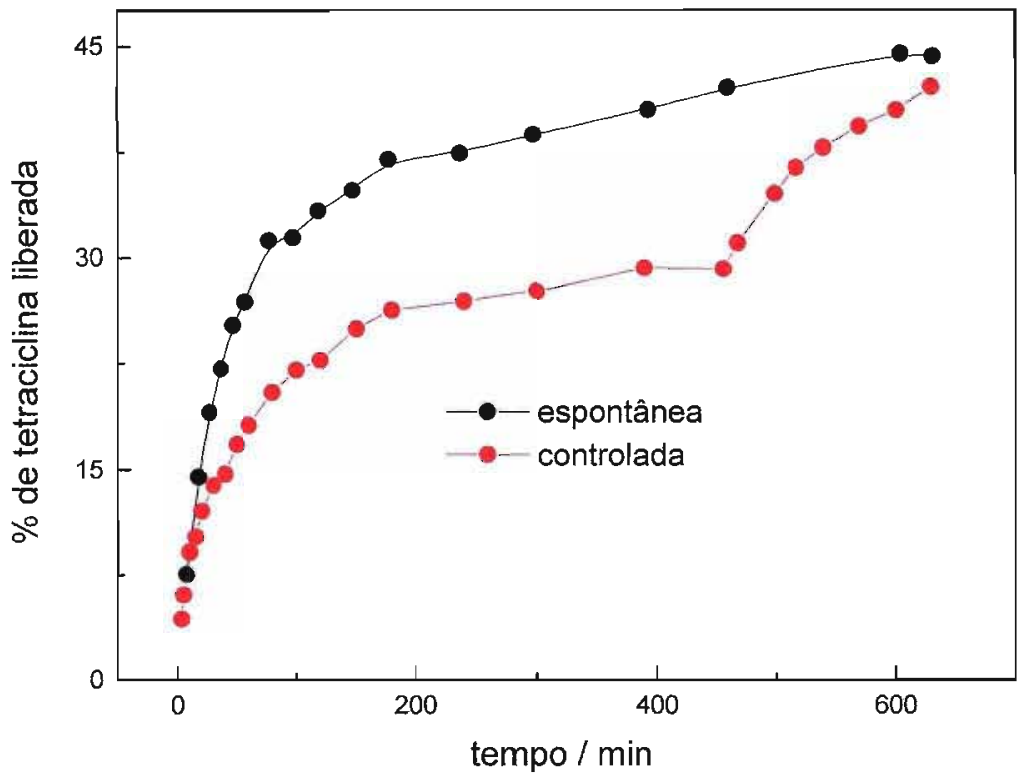

Figura 96 - Curvas de liberação de tetraciclina em $20 \mathrm{~mL}$ de solução aquosa de $\mathrm{HCl}$ 0,1mol.L $L^{-1}$. Observação: cada curva foi obtida de um compósito diferente.

A parametrização do sistema seguiu com o estudo da variação da eficiência do controle eletroquímico $(\phi)$ em função do potencial de oxidação aplicado ao sistema. Para tanto mais três liberações foram realizadas (cada uma utilizando um compósito novo). Em cada uma delas se iniciou o experimento a $-0,2 \mathrm{~V}$ e depois de se atingir uma liberação quase constante ou nula se oxidou o compósito a um determinado potencial 
$(0,2,0,4$ ou $0,8 \mathrm{~V})$. A Figura 97 mostra estes experimentos. Na curva $1 \mathrm{~A}$, o potencial primeiramente foi mudado de $-0,2$ para $0,2 \mathrm{~V}$, mas como o aumento da velocidade de liberação foi pequeno, oxidou-se o compósito novamente a $0,6 \mathrm{~V}$, obtendo-se assim a liberação mais rápida de tetraciclina. A fim de se obter o valor de $\phi$ para todas as curvas de liberação controlada, foi utilizado o mesmo procedimento descrito anteriormente de se ajustar retas às regiões próximas às mudanças de estado de oxidação da rede. A Figura 98 mostra a ampliação da região próxima às mudanças de potencial para a curva $1 \mathrm{~A}$.

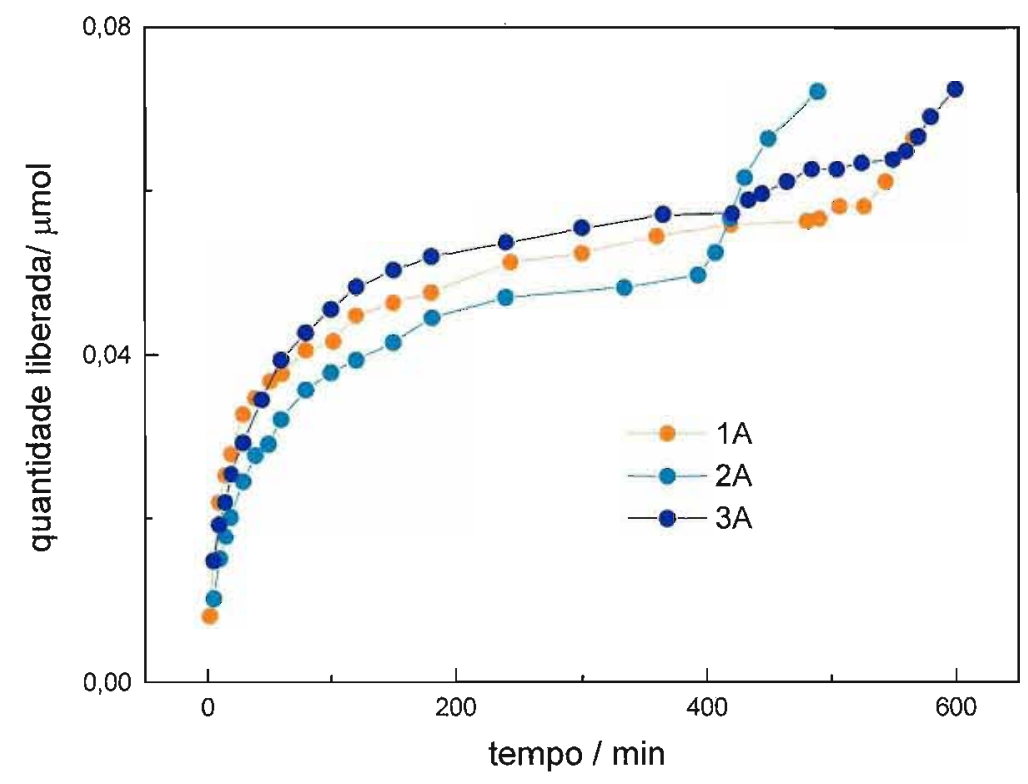

Figura 97 - Curvas de liberação controlada de tetraciclina em $20 \mathrm{~mL}$ de solução aquosa de $\mathrm{HCl} 0,1 \mathrm{~mol} \cdot \mathrm{L}^{-1}$. Curva $1 \mathrm{~A}$ - seqüência de potencial aplicada: $-0,2$ / 0,2 / 0,6V. Curva $2 \mathrm{~A}$ - seqüência de potencial aplicada: $-0,2 / 0,8 \mathrm{~V}$. Curva $3 \mathrm{~A}$ - seqüência de potencial aplicada: $-0,2 / 0,4 / 0,6 \mathrm{~V}$. Observação: cada curva foi obtida de um compósito diferente.

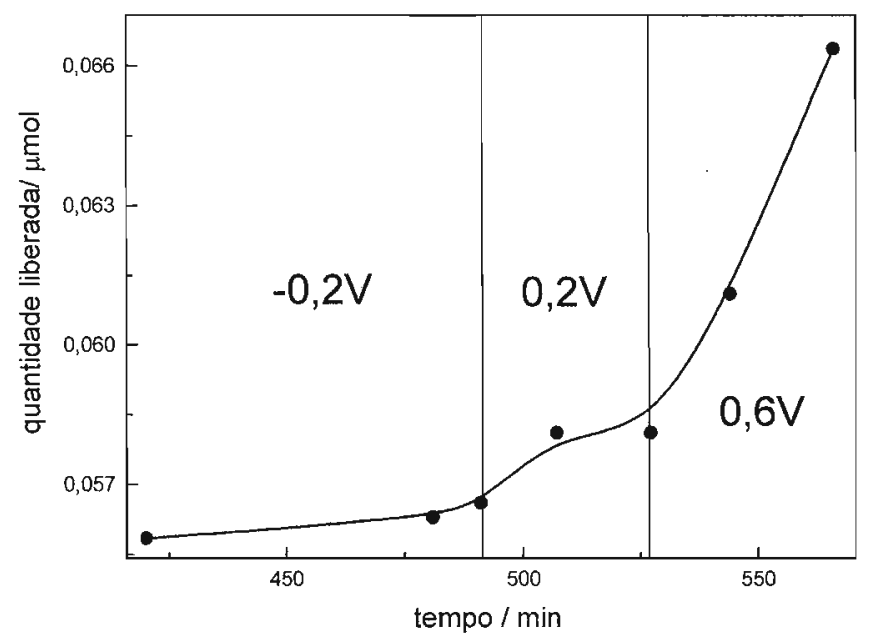

Figura 98 - Ampliação da região de mudança de potencial da curva 1A da figura 97. 
A curva $2 \mathrm{~A}$ mostra que oxidando o compósito a $0,8 \mathrm{~V}$ pode se obter um melhor aproveitamento do material, provocando uma drástica mudança na velocidade de liberação da droga: para este experimento o valor de $\phi$ foi de 12,43 , o maior desta série de experimentos (os outros valores são mostrados na tabela 15). A curva $3 \mathrm{~A}$ mostra um resultado intermediário para a eficiência do controle eletroquímico, uma vez que oxidando o compósito a $0,4 \mathrm{~V}$ obteve-se um valor de $\phi=2,45$. Tal resultado demonstra a possibilidade de se modular a velocidade de liberação de tetraciclina em função do potencial aplicado ao sistema. A curva $3 \mathrm{~A}$ mostra outra potencialidade do sistema que é uma liberação pulsada através da aplicação de um programa de potencial, ou seja, verificou-se que depois de oxidar a rede a $0,4 \mathrm{~V}$, ainda foi possível alterar a velocidade de liberação aplicando $0,6 \mathrm{~V}(\phi=7,76)$. Resultado similar pode ser visto na curva $1 \mathrm{~A}$. A Figura 99 mostra a curva $3 \mathrm{~A}$ em detalhe.

A Figura 100 mostra as quatro curvas de liberação controlada em função da porcentagem de tetraciclina liberada. Para se obter estes gráficos utilizou-se as quantidades de droga incorporada em cada compósito. A tabela 15 sumariza estes resultados e mostra também o valor de $\phi$ para cada experimento (assim como o valor da velocidade de liberação em cada estado de oxidação em cada experimento).

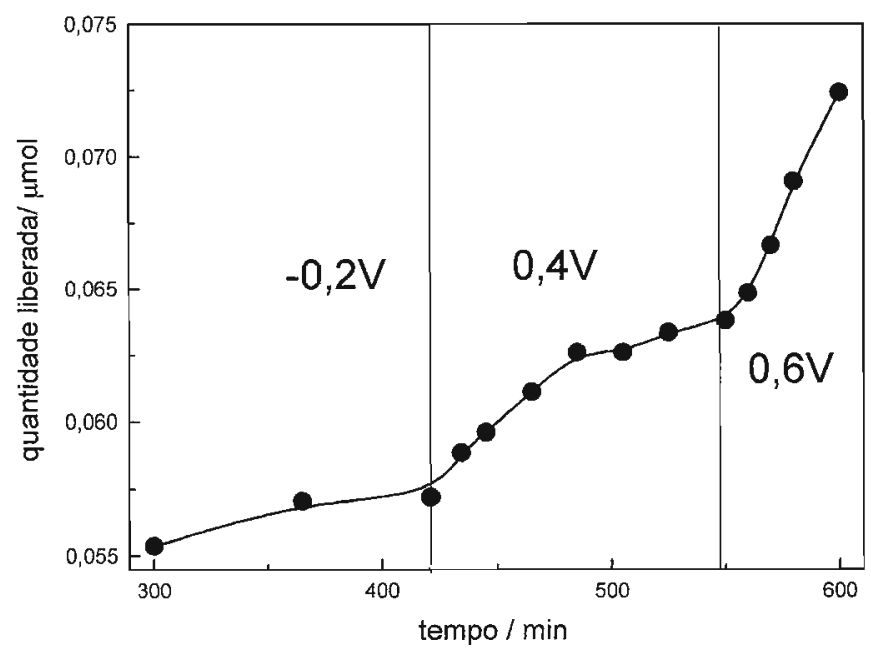

Figura 99 - Detalhe da curva 3A da figura 97. 


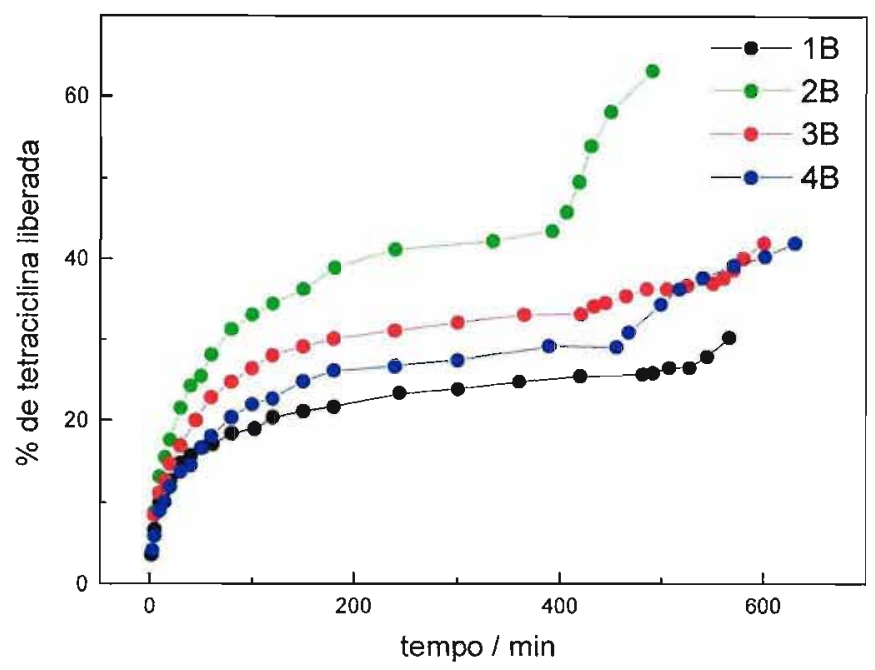

Figura 100 - Curvas de liberação controlada de tetraciclina em $20 \mathrm{~mL}$ de solução aquosa de $\mathrm{HCl} 0,1 \mathrm{~mol} \cdot \mathrm{L}^{-1}$. Curva 1B - seqüência de potencial aplicada: $-0,2 / 0,2 / 0,6 \mathrm{~V}$. Curva 2B - seqüência de potencial aplicada: $-0,2 / 0,8 \mathrm{~V}$. Curva $3 \mathrm{~B}$ - sequiência de potencial aplicada: $-0,2 / 0,4 / 0,6 \mathrm{~V}$. Curva $4 \mathrm{~B}$ - seqüência de potencial aplicada: $-0,2 / 0,6 \mathrm{~V}$. Observação: cada curva foi obtida de um compósito diferente.

Na tabela 15 também se vê o resultado referente à liberação controlada variandose o pH da solução de liberação. Como se verificou com testes de liberação em $\mathrm{HCl}$ $0,5 \mathrm{~mol} . \mathrm{L}^{-1}$ e com a espectroscopia UV-VIS que a tetraciclina sofre alterações estruturais em pHs menores do que 1, e que estas alterações tem uma determinada cinética dependente do $\mathrm{pH}$ do meio, o experimento foi realizado promovendo a mudança de potencial e de $\mathrm{pH}$ ao mesmo tempo e corrigindo os valores de quantidade de tetraciclina liberada utilizando uma curva, mostrada na Figura 101, para a degradação da molécula na condições do experimento. Portanto a liberação ocorreu a $-0,2 \mathrm{~V}$ em $20 \mathrm{~mL}$ de $\mathrm{HCl}$ $0,1 \mathrm{~mol} . \mathrm{L}^{-1}$ até determinado momento quando se alteraram as condições de liberação para $0,6 \mathrm{~V}$ e $21 \mathrm{~mL}$ de $\mathrm{HCl} 0,5 \mathrm{~mol} . \mathrm{L}^{-1}$. A Figura 102 mostra a curva de liberação já corrigida e destaca-se que esta foi a condição que forneceu o maior valor de $\phi(35,78)$, o que era esperado já que nesta condição o polímero condutor é mais eletroativo e portanto provoca uma maior alteração do tamanho dos poros do compósito. Mesmo tendo a degradação parcial da tetraciclina nestas condições, o experimento é importante no sentido de mostrar a potencialidade do sistema e sua versatilidade, já que a variação de diversos parâmetros permite controlar a velocidade de liberação de moléculas distintas como já demonstrado nesta tese (safranina, pirocatecol e tetraciclina). A Figura 103 mostra graficamente a variação de $\phi$ em função de $\Delta E=E_{f}-E_{i}$, onde $E_{i}=-0,2 V$ e $\mathrm{E}_{\mathrm{f}}$ varia de 0,2 a $0,8 \mathrm{~V}$ 
Tabela 15 - Parametrização da liberação controlada de tetraciclina.

\begin{tabular}{|c|c|c|c|c|c|c|c|}
\hline Experimento & $\mathrm{E}_{\mathrm{red}} / \mathrm{V}$ & $\mathrm{E}_{\mathrm{oxi}}{ }^{1} / \mathrm{V}$ & $\mathbf{p H}^{2}$ & $\begin{array}{c}V_{\text {red }}^{3} / \\
\text { mol.min }\end{array}$ & $\begin{array}{c}V_{o x i}{ }^{4} / \\
\text { mol.min }\end{array}$ & $\begin{array}{c}\mathrm{n}_{\mathrm{i}}^{5} / \\
\mu \mathrm{mol}\end{array}$ & $\phi^{6}$ \\
\hline 1 & $-0,2$ & 0,2 & 1 & $2,27 \cdot 10^{-11}$ & $7,17 \cdot 10^{-11}$ & 0,22 & 2,16 \\
\hline 2 & $-0,2$ & 0,4 & 1 & $2,36 \cdot 10^{-11}$ & $8,16 \cdot 10^{-11}$ & 0,17 & 2,45 \\
\hline 3 & $-0,2$ & 0,6 & 1 & $2,08.10^{-11}$ & $2,02.10^{-10}$ & 0,19 & 8,72 \\
\hline 4 & $-0,2$ & 0,8 & 1 & $2,28.10^{-11}$ & $3,07 \cdot 10^{-10}$ & 0,14 & 12,43 \\
\hline 5 & $-0,2$ & 0,6 & 0,3 & $1,68.10^{-11}$ & $6,17 \cdot 10^{-10}$ & 0,13 & 35,78 \\
\hline
\end{tabular}

${ }^{1}$ primeiro potencial de oxidação que se aplicou ao sistema durante a liberação;

${ }_{2}^{2} \mathrm{pH}$ da solução de liberação;

${ }^{3}$ velocidade de liberação da tetraciclina com o compósito reduzido (região linear);

${ }^{4}$ velocidade de liberação da tetraciclina com o compósito oxidado (regiãolinear);

${ }^{5}$ número de mols incorporado no compósito;

${ }^{6} \phi=\Delta \mathrm{V} / \mathrm{V}_{\text {red }}, \Delta \mathrm{V}=\mathrm{V}_{\text {oxi }}-\mathrm{V}_{\text {red }}$

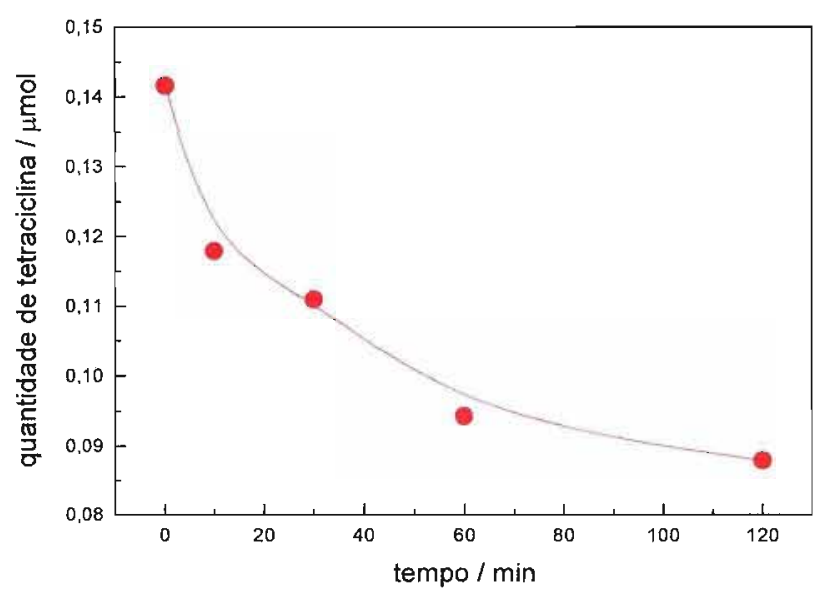

Figura 101 - Curva de degradação da tetraciclina em $\mathrm{pH}=0,3 \quad(21 \mathrm{~mL}$ de $\mathrm{HCl}$ $\left.0,5 \mathrm{~mol} \cdot \mathrm{L}^{-1}\right)$. 


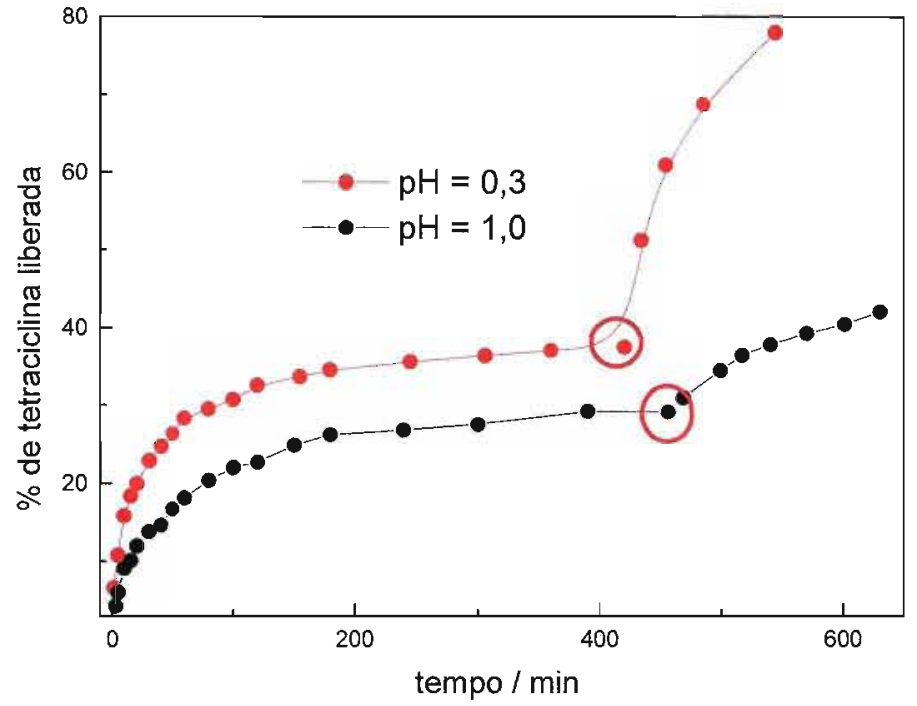

Figura 102 - Curvas de liberação controlada de tetraciclina em solução aquosa de $\mathrm{HCl}$. Efeito do $\mathrm{pH}$ no controle eletroquímico. O ponto em destaque em cada curva marca a mudança de potencial do sistema de $-0,2$ para $0,6 \mathrm{~V}$.

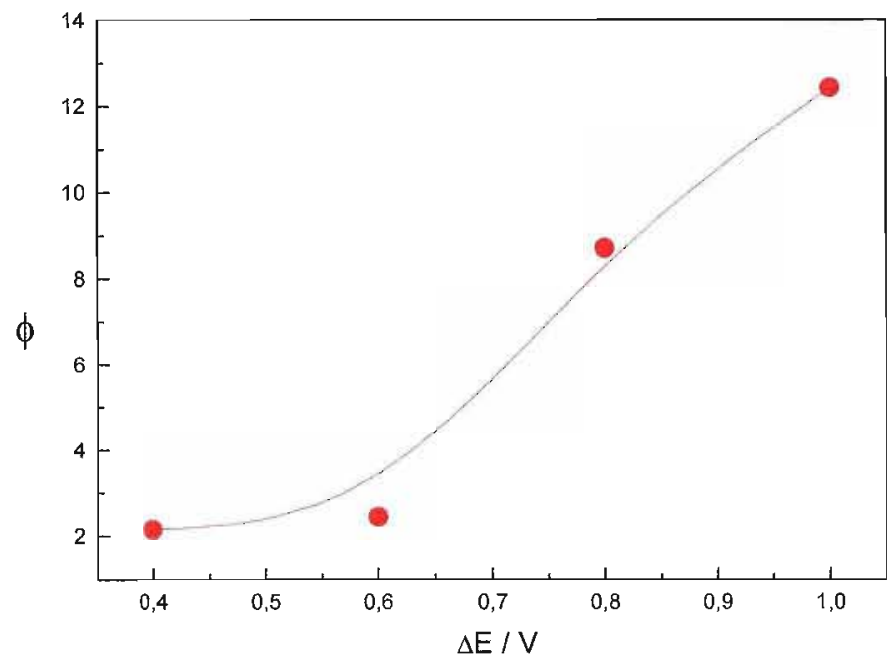

Figura 103 - Eficiência do controle eletroquímico $(\phi)$ da liberação de tetraciclina em função da mudança de potencial aplicada ao sistema $(\triangle \mathrm{E})$

Também foi verificada a possibilidade do recarregamento de um compósito com tetraciclina após se efetuar uma liberação controlada. A Figura 104 mostra a primeira e a segunda curva de liberação de um compósito e nela pode-se ver que a quantidade liberada no segundo experimento é menor do que a liberada no primeiro. Considerando que a quantidade de tetraciclina incorporada no segundo teste foi um pouco maior $(0,22 \mu \mathrm{mol})$ que a incorporada no primeiro $(0,19 \mu \mathrm{mol})$, e que o perfil de liberação com o compósito reduzido é diferente nos dois casos, pode-se dizer que a rede sofreu alterações irreversíveis durante o primeiro processo redox, o que modificou o seu perfil 
de liberação. Porém, ainda sim foi possível obter um controle eletroquímico da liberação, sendo que $\phi$ foi igual a 5,40.

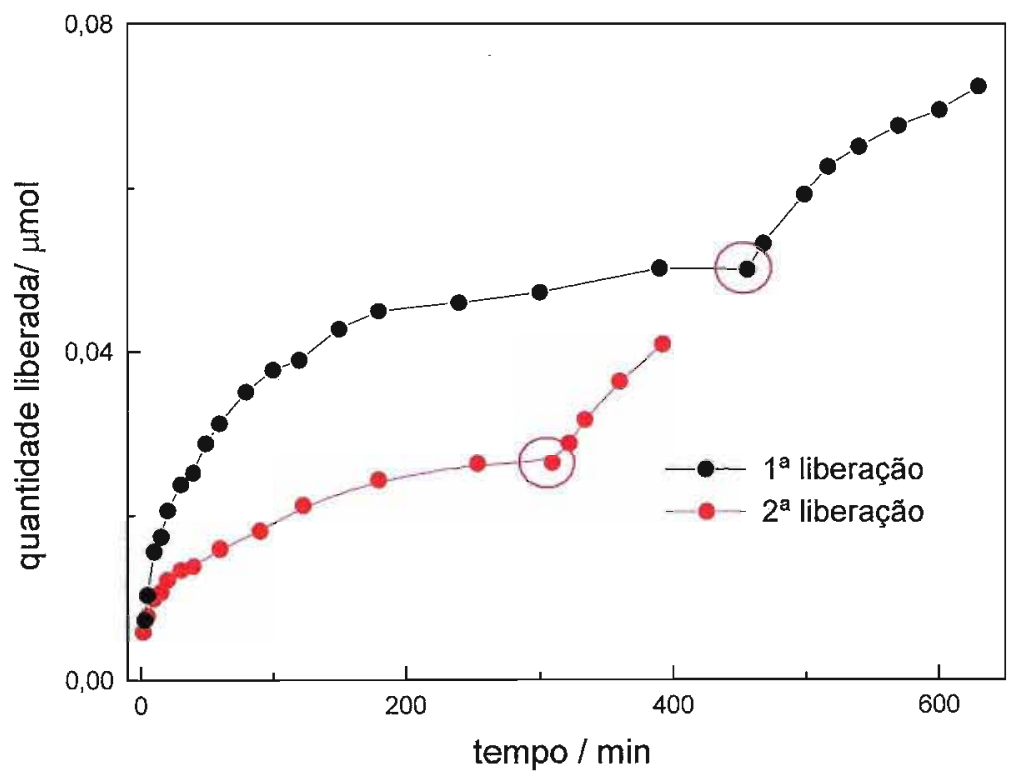

Figura 104 - Curvas de liberação de tetraciclina obtidas de um mesmo compósito. $\mathrm{O}$ ponto em destaque nas duas curvas indica o momento de mudança de estado de oxidação do compósito (de $-0,2$ para $0,6 \mathrm{~V}$ ). 


\section{5 - Conclusões}

Esta tese de doutorado explorou a aplicação de polímeros condutores como material ativo em sistemas de liberação controlada eletroquimicamente de drogas. O inicio do trabalho com sistemas baseados em filmes eletrodepositados de polímeros condutores (polianilina e polipirrol) mostrou a possibilidade de se aplicar os polimeros condutores em tais dispositivos, uma vez que foi verificado o controle da liberação no caso da utilização da polianilina carregada com ácido salicílico ou dopamina. Porém, este tipo de sistema baseado na interação eletrostática entre a droga e o polímero se mostrou limitado por alguns motivos: o próprio mecanismo de funcionamento limita o sistema à utilização de drogas carregadas eletricamente; a troca iônica diminui muito a capacidade de controle eletroquímico do polímero condutor; foi verificado que moléculas um pouco maiores que as modelo testadas não conseguem entrar/sair do filme do polímero condutor. Estes sistemas de Geração I se mostraram também bastante irreprodutíveis, portanto se considera que os polímeros condutores na forma de filmes que controlam a liberação devido ao seu estado de oxidação, ainda são promissores para a fabricação de dispositivos comerciais, porém são necessárias abordagens mais efetivas e diferentes do que se tem na literatura até hoje.

Frente a estas dificuldades todas, e na tentativa de se desenvolver sistemas menos limitados e mais reprodutíveis, apresentou-se nesta tese uma nova alternativa de sistemas poliméricos baseados em polímeros condutores e hidrogéis aplicados à liberação controlada de drogas. Classificou-se esta tetativa numa nova classe de dispositivos baseados em polímeros condutores: a Geração II, que tem o seu principio de funcionamento baseado em outras propriedades dos polímeros condutores que não a interação eletrostática droga-polímero. De fato, o compósito de polianilina / poliacrilamida reticulada, gerou uma rede condutora semi-interpenetrante capaz de controlar a liberação de moléculas como safranina, pirocatecol violeta e tetraciclina através de sua propriedade de músculo artificial. A inédita caracterização microscópica, eletroquímica e espectroscópica deste material permitiu racionalizar o mecanismo de atução do compósito a ponto de se conseguir modular a eficiência do controle eletroquímico com parâmetros como o $\mathrm{pH}$ da solução de liberação, o tamanho de poro da mariz de poliacrilamida, a quantidade de polianilina no compósito e logicamente o potencial aplicado ao sistema. 
A liberação de moléculas deste compósito é controlada, no início, principalmente por difusão, porém em tempos de liberação posteriores verificou-se um excelente nível de controle eletroquímico. Assim se propõe, nesta conclusão, a idéia de que compósitos carregados com pequenas quantidades de drogas ou que sofreram um processo de pré-tratamento (liberação da droga até a difusão se tornar mínima) podem ter exclusivamente um controle eletroquímico da liberação, gerando desta forma um sistema capaz realmente da propriedade de ligar/desliga frente a impulsos elétricos de baixa potencia. É importante ressaltar que este novo sistema também se mostrou bastante reprodutível. Assim julga-se que nesta tese há uma importante contribuição para o desenvolvimento de dispositivos cuja finalidade é melhorar a qualidade de vida de pessoas que necessitam de tratamento invasivos, constantes ou de difícil adesão por qualquer razão.

Portanto os objetivos desta tese foram alcançados e destaca-se que o estudo apresentado aqui é de caráter básico, sendo que os sistemas mostrados são considerados como modelos, mas abrem uma nova metodologia para estudos mais aplicados de polímeros condutores na área biomédica e farmacêutica. Alguns dos resultados apresentados nesta tese estão publicados ${ }^{80}$ num importante periódico de eletroquímica, onde normalmente não se encontram artigos sobre aplicações desta natureza (liberação controlada eletroquimicamente). Desta forma espera-se contribuir na tarefa de tornar a eletroquímica cada vez mais uma ciência multidisciplinar com extensões capazes de auxiliar em outras áreas do conhecimento: aos sensores, às vitais aplicações da eletroquímica em estimuladores cardíacos ou neurais ${ }^{81}$, às inovações técnicas (microscopia eletroquímica de varredura, especificamente) aplicadas ao monitoramento do tranporte molecular na pele ${ }^{81}$, ao desenvolvimento de biomateriais por métodos de eletrodeposição $^{81}$, finalmente pode-se concluir que, a liberação controlada eletroquimicamente (utilizando polímeros condutores) vem se somar as indiscutivelmente importantes aplicações da eletroquimica na medicina. 


\section{6- Apêndice}

O estudo teórico da rede de um hidrogel tem o propósito de revelar a estrutura e a configuração de suas cadeias pela aplicação de um modelo teórico apropriado. $\mathrm{O}$ conhecimento da densidade de ligações cruzadas, ou seja, o número efetivo de subunidades contendo ligações cruzadas, $v_{\mathrm{e}}$, e/ou a massa numérica média entre ligações cruzadas, $M_{\mathfrak{c}}$, é de grande importância devido aos seus efeitos nas propriedades mecânicas e físicas dos materiais produzidos e seu comportamento nas mais diversas aplicações. A caracterização da estrutura de um hidrogel é um procedimento complexo por causa dos vários tipos de redes possíveis, incluindo redes regulares, irregulares, fracamente ou altamente reticuladas e redes imperfeitas. Devido a essas variações nas redes, somente valores médios de densidade de reticulação e massa molecular entre reticulações podem ser obtidas experimental ou teoricamente.

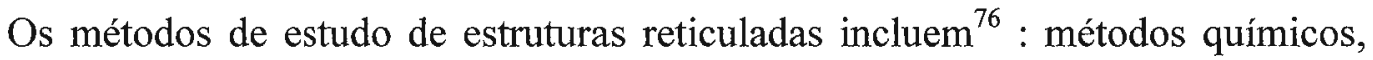
métodos de intumescimento, testes do módulo elástico, testes de dinâmica mecânica e mudança da temperatura de transição vítrea devido à reticulação. Neste apêndice é apresentado o estudo de estruturas reticuladas de poliacrilamida através da aplicação da teoria de equilíbrio de intumescimento, a escolha por este método se deve a sua simplicidade nas medidas e cálculos e principalmente por se dispor das técnicas necessárias a esta análise (cromatografia por permeação em gel e medidas diretas de densidade).

Lembrando o propósito da utilização destas redes tridimensionais de poliacrilamida neste doutorado, ou seja, matrizes para a eletropolimerização de polímeros condutores e liberação controlada eletroquimicamente de drogas, fica evidente a necessidade de se conhecer os parâmetros desta rede e como variá-los a fim de se otimizar a resposta eletroquímica na liberação. Assim, conhecer e controlar a porosidade destas redes, que é um fator preponderante na difusão da droga por estas matrizes, foi um dos principais objetivos desta parte do trabalho e realizado pela aplicação da teoria de equilíbrio de intumescimento, a qual será brevemente descrita a seguir. 


\section{1 - Teoria de equilíbrio de intumescimento: Modelo Gaussiano}

Talvez o mais conhecido modelo teórico para a determinação da massa molar numérica média entre ligações cruzadas, $M_{c}$, seja o modelo de Flory e Rehner ${ }^{76}$. $O$ desenvolvimento deste modelo é baseado em duas importantes suposições: primeiro, as cadeias poliméricas reticuladas podem ser representadas por distribuições Gaussianas, ou seja, a distância entre as extremidades da cadeia é muito menor que o tamanho desta cadeia. A segunda suposição diz que as reticulações são, em média, tetrafuncionais. Uma derivação simplificada deste modelo ${ }^{76}$ será mostrada nesta introdução. Se um polímero não-reticulado é solúvel ou termodinamicamente compatível com um líquido penetrante, então o mesmo polímero quando reticulado será intumescido por este líquido.

Três tipos de informação podem ser obtidas a partir de típicos experimentos de equilíbrio de intumescimento:

1. A quantidade de polímero não-reticulado, a qual é extraída e separada do gel e é conhecida como fração sol.

2. A distribuição de massa molecular das cadeias na fração sol.

3. A quantidade de polímero reticulado (e depois intumescido), conhecida como fração gel.

O grau de intumescimento da fração gel é tipicamente expressado como uma razão entre volumes de equilíbrio (Q) ou massas de equilíbrio (q). A razão de volumes no equilíbrio, Q, é definida como o volume do gel intumescido no equilíbrio dividido pelo volume do mesmo gel antes do intumescimento (ou como freqüentemente chamado, estado relaxado). Similarmente, a razão de massas de equilíbrio, corresponde à razão entre as massas do gel nos dois estados. Valores típicos de Q para hidrogéis com alto grau de intumescimento variam de 5 a 100 , podendo chegar a 1000 . Hidrogéis moderadamente intumescidos possuem $Q$ variando de 1,5 a 5 .

Conforme uma rede é intumescida pela absorção de solvente, as cadeias entre as ligações cruzadas assumem uma configuração mais estendida e uma força oposta à força elástica retrativa das cadeias é criada. Com o progresso no intumescimento da rede, esta força aumenta enquanto a força termodinâmica da diluição diminui. Finalmente um estado de equilíbrio de intumescimento é alcançado, aonde ambas as forças são iguais. 
A determinação da densidade de reticulação de uma rede polimérica intumescida requer a as expressões para a energia livre da mistura, $\Delta \mathrm{G}_{\mathrm{mix}}$, e para a energia livre elástica, $\Delta \mathrm{G}_{\mathrm{el}}$, consequiente da expansão da rede. Estes termos são expressos através de parâmetros termodinâmicos e elásticos do sistema polímero-agente de intumescimento.

A mudança total de energia livre, $\Delta \mathrm{G}$, resulta da mistura das moléculas penetrantes (agente de intumescimento) com uma rede polimérica amorfa e isotrópica. A mudança da energia livre pode ser expressa pela combinação da energia livre da mistura e da energia livre elástica:

$$
\Delta \mathrm{G}=\Delta \mathrm{G}_{\mathrm{mix}}+\Delta \mathrm{G}_{\mathrm{el}}(1)
$$

A relação para $\Delta \mathrm{G}_{\mathrm{mix}}$ de um polímero e de um penetrante é

$$
\Delta \mathrm{G}_{\mathrm{mix}}=\mathrm{kT}\left[\mathrm{n}_{1} \ln \mathrm{v}_{1}+\mathrm{n}_{2} \ln \mathrm{v}_{2}+\chi_{1} \mathrm{n}_{1} \mathrm{v}_{2}\right](2)
$$

onde $\mathrm{n}_{1}$ e $\mathrm{n}_{2}$ são o números de mols de agente de intumescimento e do polímero, $v_{1}$ e $v_{2}$ são as correspondentes frações de volume, $\mathbf{k}$ é a constante de Boltzmann, $\mathrm{T}$ é a temperatura, e $\chi_{1}$ é o parâmetro de Flory para a interação polímero-solvente.

Para um sistema reticulado sem cadeias poliméricas separadas $\left(\mathrm{n}_{2}=0\right)$

$$
\Delta \mathrm{G}_{\mathrm{mix}}=\mathrm{kT}\left[\mathrm{n}_{1} \ln \mathrm{v}_{1}+\chi_{1} \mathrm{n}_{1} \mathrm{v}_{2}\right](3)
$$

O processo de deformação deve ocorrer sem mudança apreciável na energia interna, e desta forma a energia livre elástica é definida como:

$$
\Delta G_{\mathrm{el}}=-\mathrm{T} \Delta \mathrm{S}_{\mathrm{el}}(4)
$$

onde $\Delta \mathrm{S}_{\mathrm{el}}$ representa a mudança de entropia resultante do processo de deformação. Para a condição de intumescimento isotrópico $\left(\alpha_{\mathrm{s}}=\alpha_{\mathrm{x}}=\alpha_{\mathrm{y}}=\alpha_{\mathrm{z}}\right)$, a energia livre elástica é dada pela equação 5 .

$$
\Delta \mathrm{G}_{\mathrm{el}}=\left(\mathrm{kT} v_{\mathrm{e}} / 2\right)\left(3 \alpha_{\mathrm{s}}^{2}-3-\ln \alpha_{\mathrm{s}}^{3}\right)(5)
$$


onde, $v_{\mathrm{e}}$ é o número de cadeias na rede e $\alpha_{\mathrm{s}}$ é o fator de expansão, que expressa a deformação linear da rede devido ao intumescimento isotrópico. O potencial químico do solvente, $\mu_{1}-\mu_{1}{ }^{0}$, num gel intumescido é dado pela equação 6 .

$$
\mu_{1}-\mu_{1}^{0}=\mathrm{N}\left(\delta \Delta \mathrm{G}_{\mathrm{mix}} / \delta \mathrm{n}_{1}\right)_{\mathrm{T}, \mathrm{p}}+\mathrm{N}\left(\delta \Delta \mathrm{G}_{\mathrm{el}} / \delta \alpha_{\mathrm{s}}\right)_{\mathrm{T}, \mathrm{p}}\left(\delta \alpha_{\mathrm{S}} / \delta \mathrm{n}_{1}\right)_{\mathrm{T}, \mathrm{p}}(6)
$$

onde $\mathrm{N}$ é o número de Avogadro.

Para determinar o termo $\left(\delta \alpha_{S} / \delta n_{1}\right)_{T, p}$ o fator de expansão precisa ser conhecido em termos do número de mols do agente de intumescimento, $\mathrm{n}_{1}$. Esta relação é dada pela equação 7 .

$$
\alpha_{\mathrm{s}}^{3}=1 / \mathrm{U}_{2}=\left(\mathrm{V}_{0}+\mathrm{n}_{1} \mathrm{~V}_{1} / \mathrm{N}\right) / \mathrm{V}_{0}(7)
$$

onde, $\mathrm{V}_{0}$ é o volume molecular da rede no seu estado relaxado, ou seja, antes do intumescimento, e $\mathrm{V}_{1}$ é o volume molar do agente de intumescimento. A resolução da derivada de $\alpha_{\mathrm{s}}$ a respeito de $\mathrm{n}_{1}$ resulta na seguinte relação:

$$
\left(\delta \alpha_{\mathrm{s}} / \delta \mathrm{n}_{1}\right)_{\mathrm{T}, \mathrm{p}}=\mathrm{V}_{1} / 3 \alpha_{\mathrm{s}}^{2} \mathrm{~V}_{0} \mathrm{~N}(8)
$$

O uso desta relação na equação 6 e a resolução das outras duas derivadas resulta na equação 9.

$$
\mu_{1}-\mu_{1}^{0}=\operatorname{RT}\left[\ln \left(1-v_{2}\right)+v_{2}+\chi_{1} v_{2}^{2}+V_{1}\left(v_{e} / V_{0}\right)\left(v_{2}^{1 / 3}-v_{2} / 2\right)\right](9)
$$

Aqui é definido a fração de volume do polímero em equilíbrio, $v_{2, s}$, como a concentração na qual a atividade do agente de intumescimento é 1 , ou quando $\mu_{1}=\mu_{1}{ }^{0}$. Então, o sistema está em equilíbrio:

$$
-\left[\ln \left(1-v_{2, s}\right)+v_{2, s}+\chi_{1} v_{2, s}^{2}\right]=V_{1}\left(v_{e} / V_{0}\right)\left(v_{2, s}^{1 / 3}-v_{2, s} / 2\right)(10)
$$

Substituindo o termo $v_{\mathrm{e}}$ por quantidades mais familiares como $\mathrm{M}_{\mathrm{c}}$, e o massa molar numérica média $\mathrm{M}_{\mathrm{n}}$, do polímero antes da reticulação, pode-se escrever: 


$$
v_{\mathrm{e}}=\mathrm{V} / \mathrm{u} \mathrm{M}_{\mathrm{c}}\left(1-2 \mathrm{M}_{\mathrm{c}} \mathrm{M}_{\mathrm{n}}\right)(11)
$$

onde $\mathrm{V}$ é o volume total e v é o volume específico do polímero. Substituindo a relação 11 na equação 10 tem-se:

$$
-\left[\ln \left(1-v_{2, s}\right)+v_{2, s}+\chi_{1} v_{2, s}^{2}\right]=\left(V_{1} / v M_{c}\right)\left(1-2 M_{c} / M_{n}\right)\left(v_{2, s}^{1 / 3}-v_{2, s} / 2\right)(12)
$$

A equação 12 pode ser rearranjada para a forma mais familiar do modelo de Flory e Rehner

$$
\frac{1}{M c}=\frac{2}{M n}-\left(v / V_{1}\right) \frac{\left[\ln \left(1-v_{2, s}\right)+v_{2, s}+\chi v_{2, s}^{2}\right]}{\left[v_{2}^{1 / 3}-v_{2, s} / 2\right]}
$$

$O$ fator $\left(1-2 M_{c} / M_{n}\right)$ é a correção para imperfeições da rede, resultantes das terminações das cadeias; este fator se reduz a 1 para o caso ideal de redes perfeitas.

A equação 13 de Flory e Rehner se aplica a redes intumescidas de polímeros reticulados, onde as ligações cruzadas são introduzidas no estado sólido (reticulação de um polímero sólido). Peppas e Merril $^{76}$ desenvolveram um modelo similar que considera situações mais comuns no estudo de hidrogéis, como a reticulação acontecendo no estado intumescido do polímero, ou seja, reticulação em solução. Como este é o modelo utilizado neste trabalho, tem-se a seguir um breve desenvolvimento da equação do modelo de Peppas e Merril para hidrogéis pouco reticulados (modelo Gaussiano) em solução. Neste modelo, $\mathrm{v}_{2, \mathrm{r}}$ é definido como a fração de volume do polímero no seu estado relaxado (fração de volume do polímero reticulado mas não intumescido) e $v_{2, s}$ é fração de volume do polímero intumescido (fração de volume do polímero depois de atingir o equilíbrio de intumescimento).

Da mesma forma que o modelo de Flory e Rehner, a mudança na energia livre é composta de um termo referente à mistura e outro referente à força retrativa elástica.

$$
\Delta \mathrm{G}=\Delta \mathrm{G}_{\mathrm{mix}}+\Delta \mathrm{G}_{\mathrm{el}}(14)
$$


Para uma rede reticulada e um solvente, a energia livre da mistura é dada pela equação 15.

$$
\Delta \mathrm{G}_{\mathrm{mix}}=\mathrm{kT}\left[\mathrm{n}_{1} \ln \mathrm{v}_{1}+\chi_{1} \mathrm{n}_{1} \mathrm{v}_{2}\right](16)
$$

os parâmetros desta equação já foram apresentados na equação 3 . O termo da força elástica também já foi mostrado, e é o mesmo da equação 4 . O fator de expansão é definido agora como:

$$
\alpha_{\mathrm{s}}=\left(\mathrm{V} / \mathrm{V}_{0}\right)^{1 / 3}
$$

Com $\mathrm{V}_{0}$ igual ao volume do gel no estado relaxado. A contribuição para a deformação do estado relaxado para o estado intumescido pode ser usada para determinar a contribuição elástica à entropia.

$$
\Delta \mathrm{S}_{\mathrm{el}}=\mathrm{C}-\mathrm{k} v_{\mathrm{e}} / 2\left[\alpha_{\mathrm{x}}^{2}+\alpha_{\mathrm{y}}^{2}+\alpha_{\mathrm{z}}^{2}-3-\ln \left(\alpha_{\mathrm{x}} \alpha_{\mathrm{y}} \alpha_{\mathrm{z}}\right)\right](18)
$$

Por definição $\Delta \mathrm{S}_{\mathrm{el}}=\mathrm{S}_{\text {intumescido }}-\mathrm{S}_{\text {relaxado, }}$ e assumindo um material isotrópico $\left(\alpha_{\mathrm{s}}=\alpha_{\mathrm{x}}=\right.$ $\alpha_{\mathrm{y}}=\alpha_{\mathrm{z}}$ ) e lembrando que no estado relaxado $\alpha_{\mathrm{s}}=1$ e no estado intumescido $\alpha_{\mathrm{s}}{ }^{3}=$ $\mathrm{V}_{\mathrm{s}} / \mathrm{V}_{\mathrm{r}}, \Delta \mathrm{S}_{\mathrm{e}}$ é definido pela equação 19 .

$$
\Delta \mathrm{S}_{\mathrm{el}}=-3 \mathrm{kT} v_{\mathrm{e}} / 2\left[\alpha_{\mathrm{s}}^{2}-1-\ln \alpha_{\mathrm{s}}\right](19)
$$

No equilíbrio, o potencial químico do agente de intumescimento no gel é igual ao potencial químico do solvente.

$$
\mu_{1}-\mu_{1}^{0}=\left(\delta \Delta \mathrm{G}_{\mathrm{mix}} / \delta \mathrm{n}_{1}\right)+\left(\delta \Delta \mathrm{G}_{\mathrm{el}} / \delta \mathrm{n}_{1}\right)=0(20)
$$

Resolvendo as derivadas que aparecem na equação 20 ,

$$
\delta \Delta \mathrm{G}_{\text {mix }} / \delta \mathrm{n}_{1}=\mathrm{RT}\left[\ln \left(1-\mathrm{v}_{2, \mathrm{~s}}\right)+\mathrm{v}_{2, \mathrm{~s}}+\chi_{1} \mathrm{v}_{2, \mathrm{~s}}{ }^{2}\right]
$$




$$
\delta \Delta \mathrm{G}_{\mathrm{el}} / \delta \mathrm{n}_{1}=\mathrm{RTV}_{\mathrm{l}} / \mathrm{v}\left(1 / \mathrm{M}_{\mathrm{c}}-2 / \mathrm{M}_{\mathrm{n}}\right) \mathrm{v}_{2, \mathrm{r}}\left[\left(\mathrm{v}_{2, \mathrm{~s}} / \mathrm{v}_{2, \mathrm{r}}\right)^{1 / 3}-0,5\left(\mathrm{v}_{2, \mathrm{~s}} / \mathrm{v}_{2, \mathrm{r}}\right)\right]
$$

e substituindo tem-se:

$R T\left[\ln \left(1-v_{2, s}\right)+v_{2, s}+\chi_{1} v_{2, s}{ }^{2}\right]+R T V_{1} / v\left(1 / M_{c}-2 / M_{n}\right) v_{2, r}\left[\left(v_{2, s} / v_{2, r}\right)^{1 / 3}-0,5\left(v_{2, s} / v_{2, r}\right)\right]=0$

Esta equação rearranjada é o modelo de Peppas e Merril:

$$
\frac{1}{M c}=\frac{2}{M n}-\frac{\left[\ln \left(1-v_{2, s}\right)+v_{2, s}+\chi v_{2, s}^{2}\right]}{V_{1} \rho_{2}\left[\left(\frac{v_{2, s}}{v_{2, r}}\right)^{1 / 3}-\frac{1}{2}\left(\frac{v_{2, s}}{v_{2, r}}\right)\right]}
$$

com $\rho_{2}=$ densidade do polímero não-reticulado. Esta expressão se reduz ao modelo de Flory e Rehner quando $v_{2, r}=1$, ou seja, quando a reticulação é realizada no estado sólido. A aplicação do modelo sem dúvida é mais simples que sua derivação, e necessita da determinação da massa molar numérica do polímero não reticulado e de medidas de massa e densidade do hidrogel relaxado e intumescido. 
6.2 - Resultados e discussões

\subsection{1 - Cromatografia por permeação em gel}

Além de fornecer a informação fundamental para o modelo de Peppas e Merril, que é a massa molar numérica média, as medidas de GPC mostraram características do mecanismo de polimerização da poliacrilamida. A polimerização de acrilamida (em água e iniciada por peroxidissulfato), mesmo na ausência do agente promotor de ligações cruzadas leva à formação de soluções com alta viscosidade ou até de estruturas reticuladas, principalmente quando se parte de porcentagens mais altas de acrilamida em solução. Tal fato impediria a análise destas soluções por GPC, porém foi verificado que a reação de polimerização poderia ser interrompida antes do proibitivo aumento da viscosidade da solução. Para parar a polimerização, simplesmente se diluía $(\sim 10 \mathrm{X})$ o meio reacional com água. Foi necessário então verificar se este procedimento não influenciaria no comprimento das cadeias poliméricas, bem como na polidispersão da poliacrilamida e para tanto foram analisadas soluções onde a polimerização foi cessada em diferentes tempos.

Aqui é importante ressaltar que, excluindo a MBA, foram estudadas seis diferentes relações monômero/oxidante, portanto para aplicar o modelo seriam necessários a princípio, seis diferentes valores de massa molar numérica. A tabela a seguir mostra essas seis relações.

Tabela 16 - Diferentes polimerizações analisadas por GPC.

\begin{tabular}{ccc}
\hline Acrilamida /g & Peroxidissulfato / & polimerização \\
\hline 0,5 & & $\mathrm{P} 1$ \\
1,0 & & $\mathrm{P} 2$ \\
1,5 & 0,010 & $\mathrm{P} 3$ \\
2,0 & & $\mathrm{P} 4$ \\
2,5 & & $\mathrm{P} 5$ \\
\hline 3,0 & & $\mathrm{P} 6$
\end{tabular}

Obs.: Polimerização na ausência de MBA, volume final $=10 \mathrm{~mL}$. 
As Figuras 105 e 106 mostram então os cromatogramas da solução de polimerização $\mathrm{P} 1$, onde a reação foi interrompida após 10 e $20 \mathrm{~min}$ de iniciada, e a comparação dos dois permite dizer que em maiores tempos de polimerização, o que ocorre não é um aumento na massa molar das cadeias, nem uma significativa mudança na polidispersão do polímero, mas sim o aumento do número de cadeias com o mesmo comprimento. Esta observação é importante, pois valida o resultado do GPC para soluções onde a polimerização foi interrompida em tempos onde ainda se tem uma solução passível de análise cromatográfica.

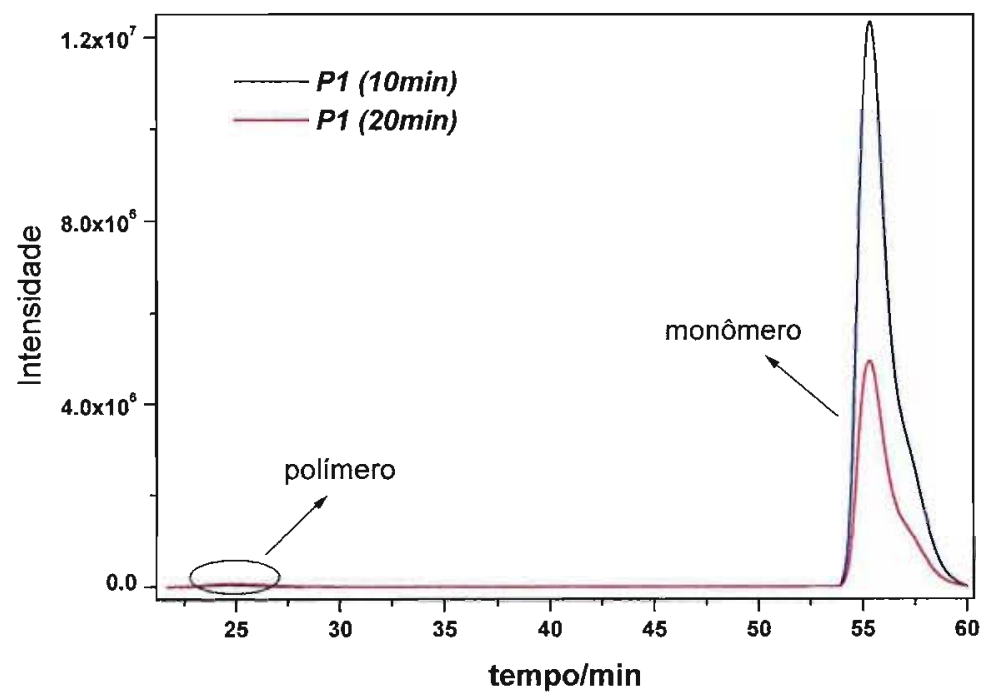

Figura 105 - Cromatogramas para a polimerização $\mathrm{P} 1$ interrompida após 10 e 20 min de reação.

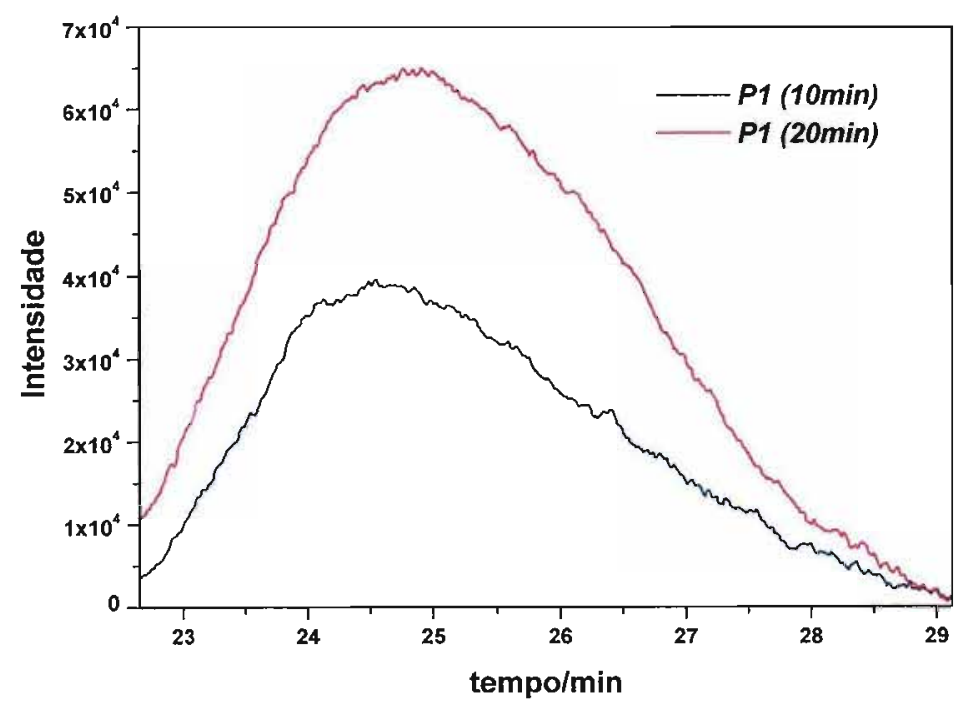

Figura 106 - Ampliação da região circulada no figura 105. 
Dificuldades instrumentais impediram a análise das seis soluções como era necessário, porém conseguiram-se os cromatogramas das soluções de polimerização (após a diluição) P1 e P6 (Figura 107) e assumiu-se que as outras polimerizações forneceriam massas molares dentro do intervalo definido pelas massas molares de P1 e P6, uma vez que estas são os extremos de concentração de acrilamida usada. Assim, decidiu-se utilizar o valor médio (tabela 17) destas duas massas para todos os hidrogéis analisados.

Tabela $17-M_{n}$ obtidas para a poliacrilamida através de medidas de GPC.

\begin{tabular}{ccc}
\hline Polimerização & $\mathbf{M}_{\mathbf{n}} / \mathbf{g} \cdot \mathbf{m o l}^{-1}$ & Média $/ \mathbf{g} \cdot \mathbf{m o l}^{-1}$ \\
\hline P1 & $2,0.10^{6}$ & $1,4.10^{6}$ \\
\hline P6 & $7,5 \cdot 10^{5}$ & \\
\hline
\end{tabular}

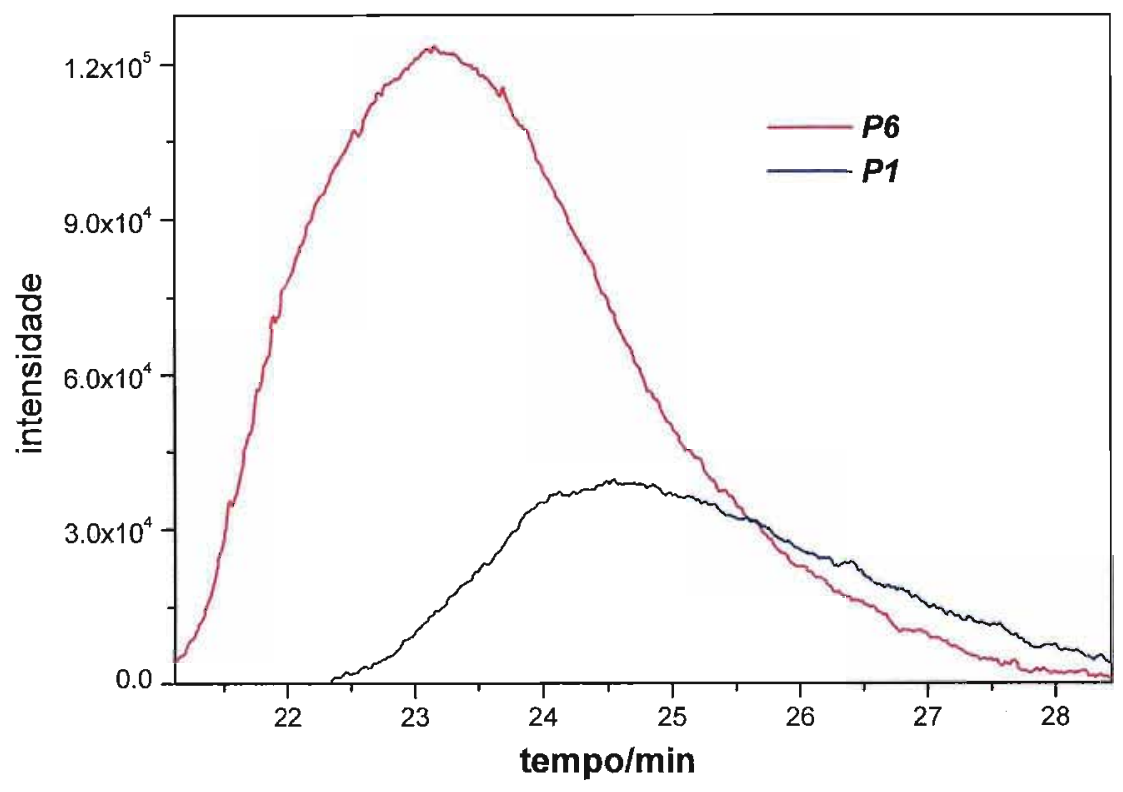

Figura 107 - Cromatogramas das polimerizações P1 e P6.

\subsection{2 - Medidas de massa e densidade}

Como discutido na introdução deste apêndice, o modelo fornece uma forma simples de se obter parâmetros da rede formada por cadeias lineares hidrofílicas, simples porque além da massa molar numérica, só são necessárias medidas de massa e 
densidade do hidrogel (e do polímero) relaxado e intumescido. Assim, mostra-se a seguir (tabelas 18 e 19) estes resultados para os 11 diferentes hidrogéis analisados e consequentemente os seis diferentes polímeros (poliacrilamida não reticulada quimicamente).

Tabela 18 - Medidas de massa e densidade dos diferentes hidrogéis intumescidos e secos.

\begin{tabular}{|c|c|c|c|c|c|}
\hline \multicolumn{6}{|c|}{ Hidrogel 1} \\
\hline \multirow{2}{*}{ parâmetro } & \multicolumn{4}{|c|}{ medida } & \multirow{2}{*}{ média } \\
\hline & 1 & 2 & 3 & 4 & \\
\hline $\mathrm{m}_{\mathrm{r}} / \mathrm{g}$ & - & 0,0270 & 0,0310 & 0,0239 & - \\
\hline $\mathrm{m}_{\mathrm{s}} / \mathrm{g}$ & 0,3175 & 0,3521 & 0,4239 & 0,3414 & - \\
\hline $\mathrm{d}_{\mathrm{r}} / \mathrm{g} \cdot \mathrm{cm}^{3}$ & - & 1,290 & 1,324 & 1,323 & 1,312 \\
\hline $\mathrm{d}_{\mathrm{s}} / \mathrm{g} \cdot \mathrm{cm}^{3}$ & 1,019 & 1,027 & 1,016 & 1,013 & 1,019 \\
\hline \multicolumn{6}{|c|}{ Hidrogel 2} \\
\hline $\mathrm{m}_{\mathrm{r}} / \mathrm{g}$ & 0,0147 & 0,0122 & 0,0091 & 0,0137 & - \\
\hline $\mathrm{m}_{\mathrm{s}} / \mathrm{g}$ & 0,4354 & 0,3513 & 0,2519 & 0,3839 & - \\
\hline $\mathrm{d}_{\mathrm{r}} / \mathrm{g} \cdot \mathrm{cm}^{3}$ & 1,319 & 1,319 & 1,306 & 1,301 & 1,311 \\
\hline $\mathrm{d}_{\mathrm{s}} / \mathrm{g} \cdot \mathrm{cm}^{3}$ & 1,002 & 1,007 & 1,000 & 1,002 & 1,003 \\
\hline \multicolumn{6}{|c|}{ Hidrogel 3} \\
\hline $\mathrm{m}_{\mathrm{r}} / \mathrm{g}$ & 0,0339 & 0,0294 & 0,0243 & 0,0131 & - \\
\hline $\mathrm{m}_{\mathrm{s}} / \mathrm{g}$ & 0,3488 & 0,2892 & 0,2240 & 0,3839 & - \\
\hline $\mathrm{d}_{\mathrm{r}} / \mathrm{g} \cdot \mathrm{cm}^{3}$ & 1,307 & 1,311 & 1,302 & 1,327 & 1,312 \\
\hline $\mathrm{d}_{\mathrm{s}} / \mathrm{g} \cdot \mathrm{cm}^{3}$ & 1,023 & 1,026 & 1,025 & 1,016 & 1,022 \\
\hline \multicolumn{6}{|c|}{ Hidrogel 4} \\
\hline $\mathrm{m}_{\mathrm{r}} / \mathrm{g}$ & 0,0529 & 0,0445 & 0,0481 & 0,0519 & - \\
\hline $\mathrm{m}_{\mathrm{s}} / \mathrm{g}$ & 0,4004 & 0,3229 & 0,3558 & 0,3829 & - \\
\hline $\mathrm{d}_{\mathrm{r}} / \mathrm{g} \cdot \mathrm{cm}^{3}$ & 1,338 & 1,322 & 1,316 & 1,323 & 1,325 \\
\hline $\mathrm{d}_{\mathrm{s}} / \mathrm{g} \cdot \mathrm{cm}^{3}$ & 1,039 & 1,033 & 1,034 & 1,033 & 1,035 \\
\hline \multicolumn{6}{|c|}{ Hidrogel 5} \\
\hline $\mathrm{m}_{\mathrm{r}} / \mathrm{g}$ & 0,0644 & 0,0817 & 0,0500 & 0,0690 & - \\
\hline $\mathrm{m}_{\mathrm{s}} / \mathrm{g}$ & 0,4322 & 0,5478 & 0,3283 & 0,4550 & - \\
\hline $\mathrm{d}_{\mathrm{r}} / \mathrm{g} \cdot \mathrm{cm}^{3}$ & 1,228 & 1,315 & 1,319 & 1,322 & 1,296 \\
\hline $\mathrm{d}_{\mathrm{s}} / \mathrm{g} \cdot \mathrm{cm}^{3}$ & 1,050 & 1,037 & 1,042 & 1,043 & 1,043 \\
\hline
\end{tabular}


Hidrogel 6

$\begin{array}{cccccc}\mathrm{m}_{\mathrm{r}} / \mathrm{g} & 0,0280 & 0,0629 & 0,0409 & - & - \\ \mathrm{m}_{\mathrm{s}} / \mathrm{g} & 0,2027 & 0,3727 & 0,2485 & - & - \\ \mathrm{d}_{\mathrm{r}} / \mathrm{g} \cdot \mathrm{cm}^{3} & 1,312 & 1,304 & 1,328 & - & 1,315 \\ \mathrm{~d}_{\mathrm{s}} / \mathrm{g} \cdot \mathrm{cm}^{3} & 1,046 & 1,044 & 1,044 & - & 1,045\end{array}$

Hidrogel 7

$\begin{array}{cccccc}\mathrm{m}_{\mathrm{r}} / \mathrm{g} & 0,0287 & 0,0335 & 0,0212 & 0,228 & - \\ \mathrm{m}_{\mathrm{s}} / \mathrm{g} & 0,2811 & 0,3278 & 0,2069 & 0,2133 & - \\ \mathrm{d}_{\mathrm{r}} / \mathrm{g} \cdot \mathrm{cm}^{3} & 1,330 & 1,318 & 1,331 & 1,319 & 1,325 \\ \mathrm{~d}_{\mathrm{s}} / \mathrm{g} \cdot \mathrm{cm}^{3} & 1,022 & 1,023 & 1,024 & 1,024 & 1,023\end{array}$

\section{Hidrogel 8}

$\begin{array}{cccccc}\mathrm{m}_{\mathrm{r}} / \mathrm{g} & 0,0682 & 0,0303 & 0,0658 & 0,0455 & - \\ \mathrm{m}_{\mathrm{s}} / \mathrm{g} & 0,4063 & 0,1811 & 0,3958 & 0,2720 & - \\ \mathrm{d}_{\mathrm{r}} / \mathrm{g} \cdot \mathrm{cm}^{3} & 1,317 & 1,309 & 1,237 & 1,307 & 1,292 \\ \mathrm{~d}_{\mathrm{s}} / \mathrm{g} \cdot \mathrm{cm}^{3} & 1,045 & 1,043 & 1,044 & 1,043 & 1,044\end{array}$

\section{Hidrogel 9}

$\begin{array}{cccccc}\mathrm{m}_{\mathrm{r}} / \mathrm{g} & 1,316 & 1,297 & 1,302 & 1,323 & 1,309 \\ \mathrm{~m}_{\mathrm{s}} / \mathrm{g} & 0,3932 & 0,3033 & 0,2453 & 0,3553 & - \\ \mathrm{d}_{\mathrm{r}} / \mathrm{g} \cdot \mathrm{cm}^{3} & 1,316 & 1,297 & 1,302 & 1,323 & 1,309 \\ \mathrm{~d}_{\mathrm{s}} / \mathrm{g} \cdot \mathrm{cm}^{3} & 1,045 & 1,044 & 1,053 & 1,046 & 1,047\end{array}$

\section{Hidrogel 10}

$\begin{array}{cccccc}\mathrm{m}_{\mathrm{r}} / \mathrm{g} & 0,0531 & 0,0421 & 0,056 & 0,0774 & - \\ \mathrm{m}_{\mathrm{s}} / \mathrm{g} & 0,3467 & 0,2687 & 0,3287 & 0,4826 & - \\ \mathrm{d}_{\mathrm{r}} / \mathrm{g} \cdot \mathrm{cm}^{3} & 1,308 & 1,291 & 1,267 & 1,291 & 1,289 \\ \mathrm{~d}_{\mathrm{s}} / \mathrm{g} \cdot \mathrm{cm}^{3} & 1,041 & 1,037 & 1,041 & 1,043 & 1,041\end{array}$

\section{Hidrogel 11}

\begin{tabular}{cccccc}
$\mathrm{m}_{\mathrm{r}} / \mathrm{g}$ & 0,0574 & 0,0637 & 0,0976 & 0,0748 & - \\
$\mathrm{m}_{\mathrm{s}} / \mathrm{g}$ & 0,2526 & 0,2764 & 0,4262 & 0,3256 & - \\
$\mathrm{d}_{\mathrm{r}} / \mathrm{g} \cdot \mathrm{cm}^{3}$ & 1,323 & 1,299 & 1,305 & 1,292 & 1,305 \\
\hline $\mathrm{d}_{\mathrm{s}} / \mathrm{g} \cdot \mathrm{cm}^{3}$ & 1,061 & 1,065 & 1,068 & 1,072 & 1,067
\end{tabular}

$\mathrm{m}_{\mathrm{r}}=$ massa do hidrogel relaxado ( $\left.\mathrm{seco}\right) ; \mathrm{m}_{\mathrm{s}}=$ massa do hidrogel intumescido; $\mathrm{d}_{\mathrm{r}}=$ densidade do hidrogel relaxado; $\mathrm{d}_{\mathrm{s}}=$ densidade do hidrogel intumescido. 
Tabela 19 - Medidas de densidade das poliacrilamidas sintetizadas.

\begin{tabular}{ccccc}
\hline \multirow{2}{*}{ Polimerização } & \multicolumn{3}{c}{ Medidas $/ \mathbf{g . c m}$} & \multirow{2}{*}{ Média $/ \mathbf{g . c m}^{\mathbf{3}}$} \\
\cline { 2 - 4 } P1 & $\mathbf{1}$ & $\mathbf{2}$ & $\mathbf{3}$ & \\
P2 & 1,254 & 1,259 & 1,246 & 1,256 \\
P3 & 1,291 & 1,290 & 1,268 & 1,283 \\
P4 & 1,326 & 1,290 & 1,280 & 1,299 \\
P5 & 0,939 & 1,228 & 1,181 & 1,116 \\
P6 & 1,342 & 1,280 & 1,234 & 1,285 \\
\hline
\end{tabular}
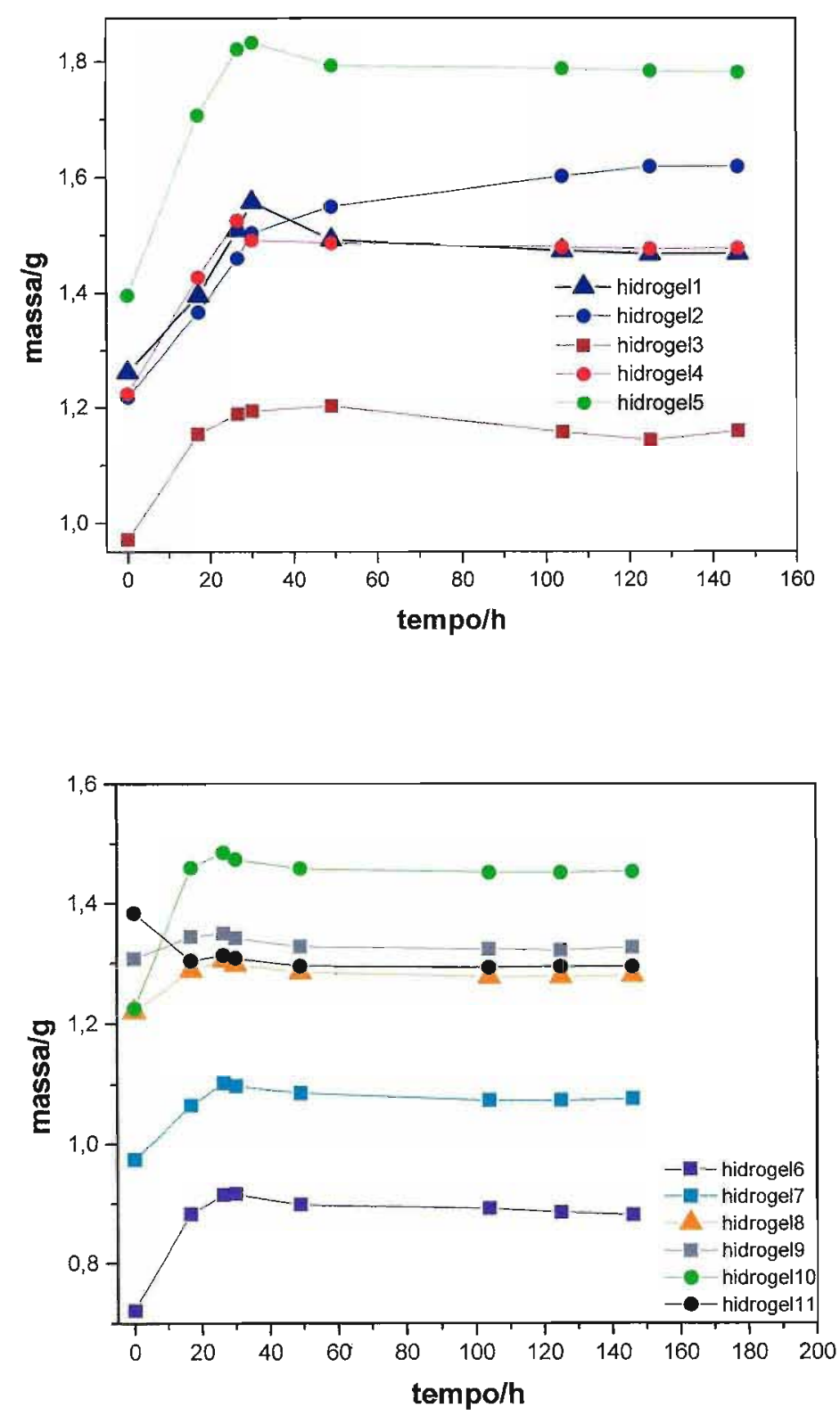

Figura 108 - Evolução da massa dos hidrogéis em água. 
Para se determinar a massa correspondente ao intumescimento máximo dos hidrogéis, apresentada na tabela 18, seguiu-se a variação de massa com o tempo em contado com água, como pode ser visto na Figura 108, onde o tempo zero corresponde ao hidrogel logo após a síntese. Para se obter a massa dos hidrogéis relaxados, procedeu-se de forma semelhante: o hidrogel era seco em estufa a $60^{\circ} \mathrm{C}$ e sua massa determinada de hora em hora até alcançar um valor mínimo constante. A densidade (dos hidrogéis relaxados e intumescidos) foi determinada pelo princípio de Arquimedes, ou seja, pela determinação de sua massa ao ar e num líquido de menor densidade, no caso, a água; a balança na qual foram realizadas as medidas possui um algoritmo que já fornece a densidade após as pesagens.

\subsection{3 - Tratamento dos dados}

Como apresentado na introdução, aplicou-se a equação do modelo de Peppas e Merril referente a hidrogéis com uma distribuição gaussiana das cadeias poliméricas devido ao moderado grau de reticulação destes hidrogéis. Diz-se que os hidrogéis aqui estudados são moderadamente reticulados com base nos valores nominais de razão de reticulação $(\mathrm{X})$, que é a razão do número de mols do agente reticulcante pelo número de mols de acrilamida usados na copolimerização. As razões de reticulação utilizada estão entre 0,014 e 0,062 , o que segundo Peppas $^{76}$ define um hidrogel moderadamente reticulado. Se o hidrogel for sintetizado a partir de valores nominais de $\mathrm{X}$ da ordem de $10^{3}$, considera-se então um material altamente reticulado e o modelo aplicado seria o não-gaussiano. Nesta equação, tem-se os parâmetros que entram diretamente como $\chi\left(-0,73\right.$, para poliacrilamida/água), $M_{n}$ e $V_{1}$, porém é necessário o cálculo de $v_{2, s}$ e $v_{2, r}$ a partir dos dados de massa e densidade obtidos:

$$
v_{2, \mathrm{~s}}=V_{\mathrm{p}} / \mathbf{V}_{\mathrm{g}, \mathrm{s}} \text { e } v_{2, \mathrm{r}}=\mathbf{V}_{\mathrm{p}} / \mathbf{V}_{\mathrm{g}, \mathrm{r}}
$$

onde $\mathrm{V}_{\mathrm{p}}=\mathrm{m}_{\mathrm{pol}} / \mathrm{d}_{\mathrm{pol}}$, com $\mathrm{m}_{\mathrm{pol}}$ e $\mathrm{d}_{\mathrm{pol}}$ igual à massa e à densidade da poliacrilamida (sem reticular) seca; $\mathrm{V}_{\mathrm{g}, \mathrm{r}}=\mathrm{m}_{\mathrm{r}} / \mathrm{d}_{\mathrm{r}}$ e $\mathrm{V}_{\mathrm{g}, \mathrm{s}}=\mathrm{m}_{\mathrm{s}} / \mathrm{d}_{\mathrm{s}}, \mathrm{m}_{\mathrm{r}}, \mathrm{m}_{\mathrm{s}}, \mathrm{d}_{\mathrm{r}}, \mathrm{d}_{\mathrm{s}}$ definidos na tabela 18 . Notar que os subscritos $r$ e $s$ se referem respectivamente aos estados relaxado e intumescido do hidrogel. 
Assim, têm-se todos os parâmetros para explorar as características destas redes poliméricas; do modelo obtém-se diretamente o valor de $M_{c}$, que representa o tamanho médio dos seguimentos poliméricos entre ligações cruzadas:

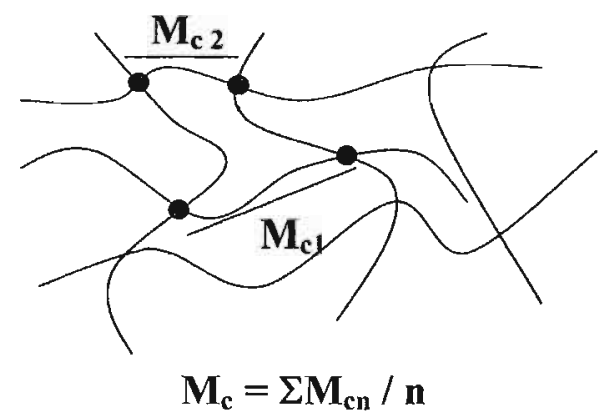

Figura 109 - Esquema das cadeias hidrofílicas de poliacrilamida reticulada e a definição de $M_{c}$.

A densidade de ligações cruzadas $\left(\rho_{x}\right)$ é dada pela relação $\rho_{x}=\rho_{2} /$ Mc; a razão de intumescimento (Q), que é um fator comumente utilizado para descrever a capacidade do hidrogel em absorver água é simplesmente a razão $\mathrm{V}_{\mathrm{g}, \mathrm{s}} / \mathrm{V}_{\mathrm{g}, \mathrm{r}}$. Aqui destaca-se que o parâmetro mais importante, a ser obtido pela aplicação deste modelo, para a eficiência do hidrogel como matriz para a eletropolimerização de polímeros condutores e finalmente para a liberação controlada eletroquimicamente de drogas é o tamanho de poros $(\xi)$. Portanto, será dada uma maior ênfase na discussão dos tamanhos de poro obtidos através da seguinte equação ${ }^{76}$ :

$$
\xi=0,1 V_{2, s}^{-1 / 3}\left(C_{n} \frac{2 M_{c}}{M}\right)^{1 / 2} \delta
$$

onde:

$\mathrm{M}$ - massa molecular do mero $\left(71,08 \mathrm{~g} \cdot \mathrm{mol}^{-1}\right)$;

$\mathrm{C}_{\mathrm{n}}-$ coeficiente de rigidez, que foi usado o do poli (metacrilato de metila) 6,9;

$\delta$ - comprimento de uma ligação individual C-C, $0,154 \mathrm{~nm}$. 
Uma vez apresentadas todas as formas de cálculo, e lembrando que cada medida foi realizada no mínimo em triplicata, mostra-se na tabela 20 os parâmetros da rede tridimensional de poliacrilamida quimicamente reticulada.

Primeiramente pode-se avaliar o resultado da aplicação da teoria de equilíbrio de intumescimento na obtenção de $\rho_{\mathrm{x}}, \mathrm{M}_{\mathrm{c}}$ e $\mathrm{Q}$. Antes é necessário definir $\% \mathrm{~T}$ e \%C, que são formas comuns de se expressar as formulações de hidrogéis de poliacrilamida reticulados com MBA: \%T representa a porcentagem em massa de acrilamida e MBA por $100 \mathrm{~mL}$ de solução e $\% \mathrm{C}$ representa a porcentagem de MBA na soma dos dois monômeros (acrilamida e MBA). Em relação ao comportamento esperado, ou seja, aumento na concentração do hidrogel (aumento de \%T) e aumento na concentração de agente promotor de ligações cruzadas (aumento de \%C) resultando em hidrogéis mais reticulados (maior $\rho_{\mathrm{x}}$ ), com menor capacidade de absorver água (menor Q) e logicamente esse comportamento se deve a uma maior freqüência de ligações cruzadas na rede e, portanto um menor valor de $\mathrm{M}_{\mathrm{c}}$, o modelo mostrou resultados compatíveis.

O maior interesse deste estudo foi o de verificar se os diferentes hidrogéis sintetizados teriam propriedades diferentes o suficiente para que quando aplicados como matrizes para os compósitos com polímeros condutores, gerassem sistemas capazes de otimizar o controle eletroquímico da liberação de moléculas-modelo. A ligação entre os parâmetros aqui estudados e os referentes à eletroliberação foi discutida na seção 4.3.7.1.3. Foi verificado porém, que os valores de $\% \mathrm{~T}$ e $\% \mathrm{C}$ utilizados resultaram em hidrogéis distintos como era necessário. É conhecido ${ }^{79}$ que para um determinado valor de \%T , o aumento de \%C causa uma diminuição no tamanho de poros da rede até atingir um ponto crítico, a partir do qual o aumento em $\% \mathrm{C}$ resulta em redes mais abertas, ou seja, estruturas macroporosas devido à união das cadeias poliméricas (agregação lateral) e à formação de fibras que deixam grandes espaços na estrutura tridimencional, como mostrado na Figura 110.
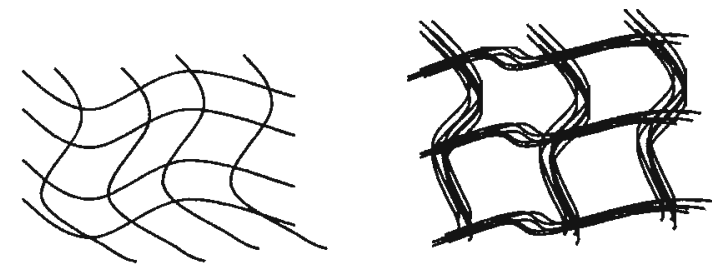

Figura 110 - Direita: distribuição espacial das cadeias polimericas e poros da rede de poliacrilamida reticulada abaixo do ponto crítico. Esquerda: hipótese de agregação lateral das cadeias causada por um valor de $\% \mathrm{C}$ acima do ponto crítico. Note que a agregação lateral explica o aumento do tamanho de poro com o aumento de $\% \mathrm{C}$ acima do ponto crítico. 
Analisando então os hidrogéis $4,8,9$ e 11 , onde foi variada a $\% \mathrm{C}$ para $\% \mathrm{~T}=$ $20 \%$, pode-se dizer o ponto crítico, para essa série, não foi alcançado, uma vez que o tamanho de poro sempre diminui. Para melhor visualização dos resultados, têm-se dois grupos de hidrogéis analisados separadamente: um com \%C fixa em $5 \%$ e outro, como já dito, com \%T fixa em 20\%. A Figura 111 mostra então $\rho_{\mathrm{x}}, \mathrm{Q}, \xi$, e a porcentagem de água (em massa) contido nos hidrogéis em função de \%T e \%C. O intuito destas comparações é validar o modelo, uma vez que o comportamento mostrado é o esperado, por exemplo, ao se reticular mais o hidrogel (> \%C) tem-se menores valores de Q e $\xi$ e logicamente uma maior densidade de reticulação, o mesmo acontece quando se aumenta $\%$ T. Tão importante quanto validar o modelo é, com estes resultados, identificar qual a forma mais eficaz de se conseguir diferentes hidrogéis, seja pela variação de $\% \mathrm{~T}$ ou de $\% \mathrm{C}$, para tanto verificou-se a variação do tamanho de poro. A variação de $\% \mathrm{~T}$ de 15 a $30 \%$ resultou em uma variação de $45 \%$ no tamanho de poro e a variação de $\% \mathrm{C}$ de 5 a $12 \%$ resultou numa diminuição de $44,5 \%$ de $\xi$, assim pode-se dizer que nas faixas de concentrações avaliadas, os dois parâmetros são igualmente importantes.

Mais especificamente em relação ao tamanho de poros obtidos, têm-se valores considerados como muito pequenos, por exemplo, o hidrogel 11 teria $\xi$ da ordem de uma ligação química e seria considerado um material não-poroso, mas o sucesso do modelo pode estar mais na confirmação de um comportamento, ou seja, em assegurar para qual direção se vai (rede com maior ou menor porosidade) ao se alterar as relações entre os monômeros na solução de síntese, do que no fornecimento de um valor real de $\mathrm{M}_{\mathrm{c}}$ ou de $\xi$. Contudo, a eletroforese de $\operatorname{proteínas~}^{75}$ fornece valores de $\xi$ de 5-20 nm para o hidrogel 2, o que difere no máximo uma ordem de grandeza do encontrado na aplicação da teoria de equilíbrio de intumescimento.

A aplicação do modelo de Peppas e Merril requer algumas suposições como discutido na introdução e se aplica a hidrogéis formados pela reticulação em solução de cadeias poliméricas já existentes. Um problema adicional poderia ser encontrado no caso da preparação de hidrogéis de poliacrilamida, uma vez que a reticulação e a polimerização ocorrem em solução e simultaneamente, ou seja, ocorre uma copolimerização. Nestas situações o valor de $M_{n}$ necessário no cálculo de $M_{c}$ não é conhecido a priori. O método utilizado para solucionar este problema foi o de polimerizar a acrilamida na ausência de MBA e determinar nas mesmas condições experimentais o valor de $M_{n}$ para o polímero não-reticulado. Esta seria uma 
aproximação grosseira, uma vez que a MBA poderia alterar muito o tamanho das cadeias poliméricas, que resultaria em valores anômalos dos parâmetros obtidos. Porém uma simulação com valores de $\mathrm{M}_{\mathrm{n}}$ variando de $10^{4}$ a $10^{8}$ (lembrando que o valor efetivamente utilizado foi de $1,4.10^{6}$ ) mostrou que $M_{c}$ é praticamente independente da massa molar da poliacrilamida, dependendo somente das frações de volume do hidrogel relaxado e intumescido. Assim não se atribui os baixos valores de $M_{c}$ e consequentemente de $\xi$ ao valor de $\mathrm{M}_{\mathrm{n}}$ utilizado no modelo. A literatura ${ }^{76}$ já mostrava, que pelo menos para o PHEMA, o valor de $M_{c}$ calculado é independente de $M_{n}$ se um valor de 75000 ou maior fosse utilizado.

Tabela 20 - Parâmetros da rede de poliacrilamida reticulada.

\begin{tabular}{|c|c|c|c|c|}
\hline Hidrogel & $\rho_{\mathrm{x}} / 10^{-3}{\mathrm{~mol} . \mathrm{cm}^{-3}}^{-3}$ & $\mathrm{M}_{\mathrm{c}} /{\mathrm{g} \cdot \mathrm{mol}^{-1}}^{-1}$ & $\mathbf{Q}$ & $\xi / \mathbf{n m}$ \\
\hline 1 & $0,66 \pm 0,03$ & $1627 \pm 458$ & $17,63 \pm 0,83$ & $0,758 \pm 0,023$ \\
\hline 2 & $0,16 \pm 0,01$ & $7695 \pm 453$ & $37,40 \pm 1,07$ & $2,046 \pm 0,081$ \\
\hline 3 & $1,05 \pm 0,08$ & $1244 \pm 99$ & $12,49 \pm 0,58$ & $0,561 \pm 0,033$ \\
\hline 4 & $2,03 \pm 0,05$ & $592 \pm 16$ & $9,47 \pm 0,16$ & $0,344 \pm 0,006$ \\
\hline 5 & $2,17 \pm 0,04$ & $593 \pm 12$ & $8,26 \pm 0,09$ & $0,338 \pm 0,005$ \\
\hline 6 & $2,29 \pm 0,42$ & $582 \pm 118$ & $8,07 \pm 0,88$ & $0,306 \pm 0,008$ \\
\hline 7 & $1,13 \pm 0,03$ & $1107 \pm 28$ & $12,53 \pm 0,10$ & $0,524 \pm 0,009$ \\
\hline 8 & $2,82 \pm 0,03$ & $427 \pm 4$ & $7,41 \pm 0,02$ & $0,274 \pm 0,002$ \\
\hline 9 & $2,94 \pm 0,12$ & $410 \pm 16$ & $7,06 \pm 0,17$ & $0,266 \pm 0,007$ \\
\hline 10 & $2,02 \pm 0,07$ & $644 \pm 22$ & $7,91 \pm 0,14$ & $0,356 \pm 0,008$ \\
\hline 11 & $4,77 \pm 0,07$ & $252 \pm 3$ & $5,34 \pm 0,03$ & $0,191 \pm 0,002$ \\
\hline
\end{tabular}



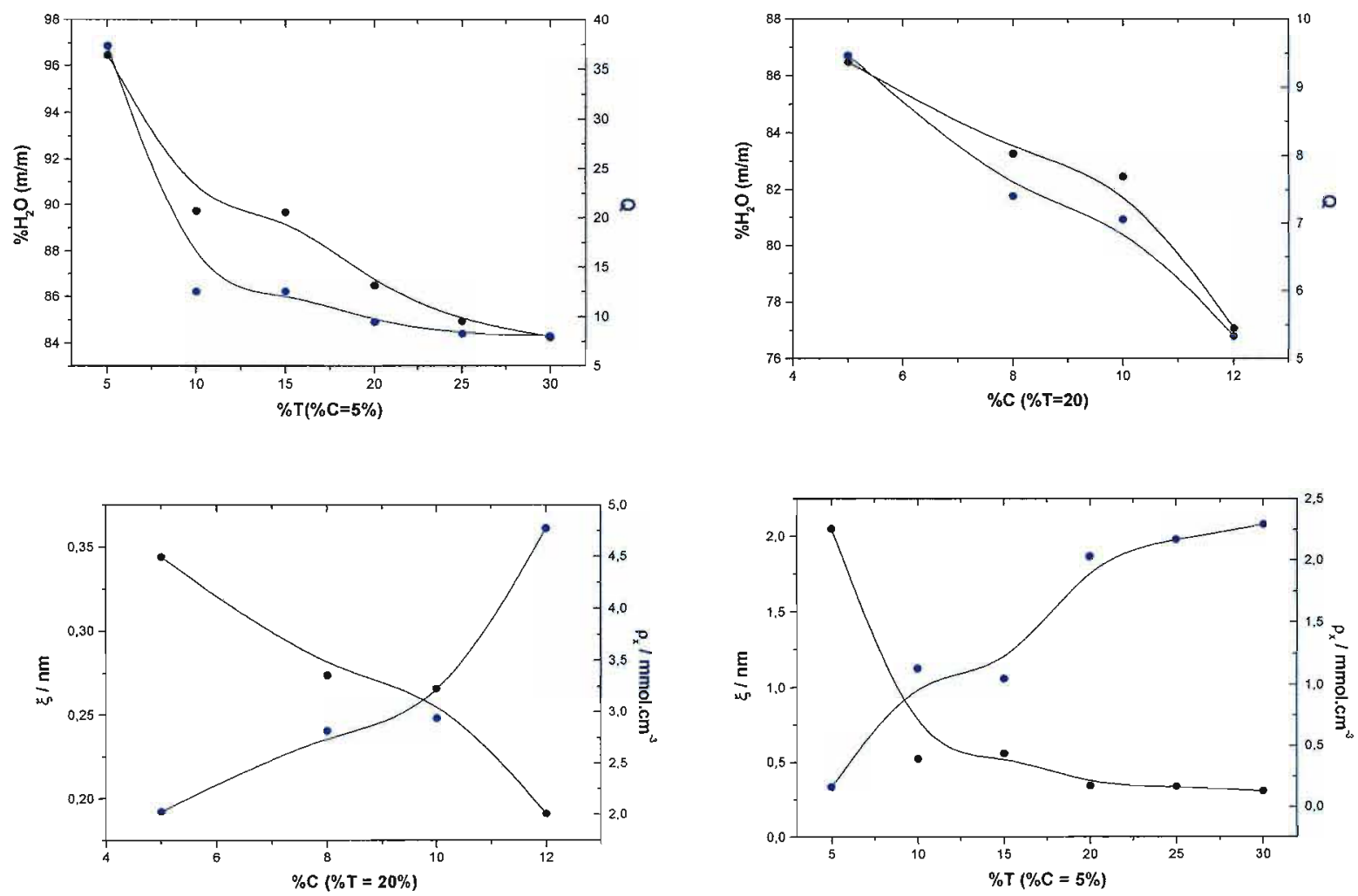

Figura 111 - Variação de $\rho_{\mathrm{x}}, \mathrm{Q}, \xi$, e a porcentagem de água (em massa) contido nos hidrogéis em função de $\% \mathrm{~T} \mathrm{e} \% \mathrm{C}$.

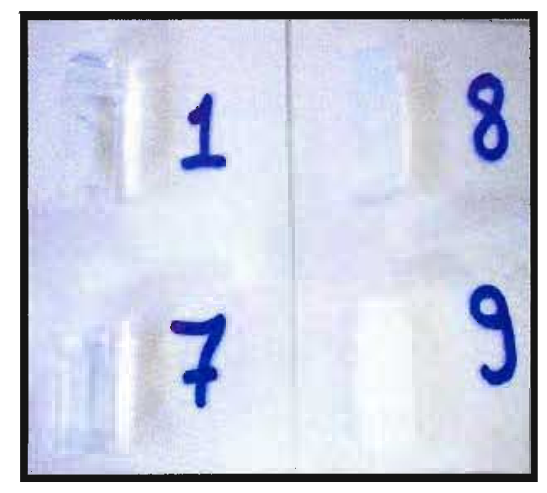

Figura 112 - Hidrogéis 1,7,8 e 9 - diferenças na turbidez em função da concentração.

A Figura 112 mostra uma fotografia de quatro hidrogéis sintetizados. Os hidrogéis de poliacrilamida podem ser transparentes ou opacos. A opacidade surge acima de um determinado valor de \%C (que obviamente depende de \%T) e está relacionada com o aumento de tamanho de poros $^{79}$. Porém como já discutido, o aumento do tamanho de poros com $\% \mathrm{C}$ só ocorre acima de um valor crítico, e ao menos para os hidrogéis $4,8,9$ e 11 ainda não se atingiu este ponto (uma vez que $\xi$ só diminui com 
\%C), mas a opacidade cresce, a despeito da diminuição do tamanho de poros. Tal contradição ainda não pode ser explicada, e aliada aos valores muito baixos de $\xi$ obtidos traz a necessidade de se caracterizar as redes de poliacrilamida através de outra metodologia ou adotar valores relativos de tamanho de poros como se fez nesta tese.

Para finalizar, a Figura 113 mostra de forma mais visual $\xi$ calculado para todos os hidrogéis sintetizados.

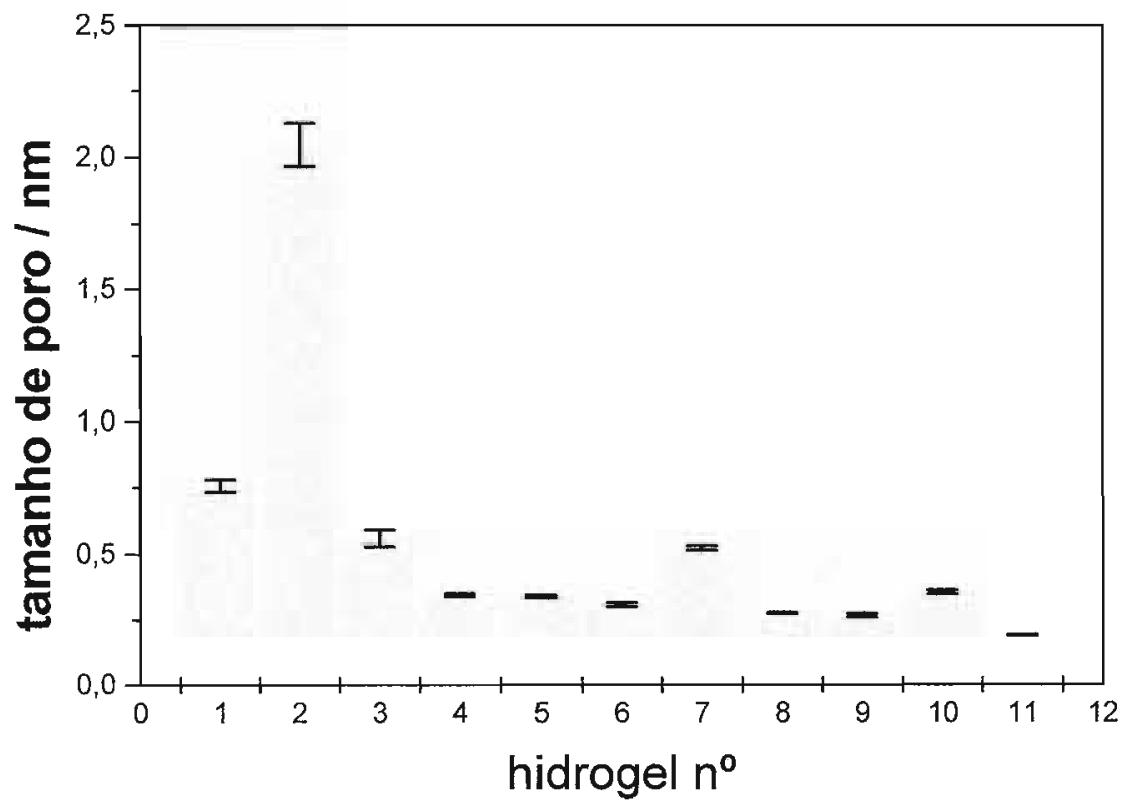

Figura 113 - Tamanho de poro para os 11 hidrogéis sintetizados. 


\section{7 - Referências bibliográficas}

1. Teixeira, P.R., Paiva, V., Shima, E., Tá Dificil de Engolir? Experiências de adesão ao tratamento anti-retroviral em São Paulo, NEPAIDS, São Paulo, 2000.

2. Chien, Y.W., Novel Drug Delivery Sistems: Fundamentals, Developmental Concepts and Biomedical Assessments, Dekker, New York (1982).

3. Chien, Y.W., Novel Drug Delivery Sistems, $2^{\mathrm{a}}$ ed., Dekker, New York (1992).

4. Rosoff, M., Controlled Release of Drugs, Polymers and Aggregate Systems, VHC, (1989).

5. Dickinson, P.A., Kellaway, I.W., Taylor, G., Mohr, D, Nagels, K., Wolff, H.M., Int. J. Pharm., 148 (1997), 55.

6. Narisawa, S., Nagata, M., Ito, T., Yohino, H., Hirakawa, Y., Noda, K., J. Control. Release, 33(2) (1995), 253.

7. Morita, R., Honda, R. Takahashi, Y., J. Control. Release, 68 (2000), 115.

8. MacDiarmid, A.G., Epstein, A.J., Synth. Met., 65, (1994), 130.

9. Huang, W., Humphrey, B.D., MacDiarmid, A.G., J. Chem. Soc., 82 (1986), 2385.

10. Mattoso, L.H.C., Quim. Nova, 19(4) (1996), 388.

11. Bodalia, R., Stern, R., Batich, C., Duran, R., J. Polym. Sci. Polym. Commum., 31 (1993), 2123.

12. Yien, W., Focke,W.W., Ray, A., MacDiarmid,A.G., J. Phys. Chem., 93 (1989), 495.

13. Bernard, M-C., Torresi, S.I.C. , Goff, A. H-L., Electrochim. Acta, 44 (1999), 1989.

14. Kang, E. T., Li, Z.F., Neoh, K.G., Dong,Y.Q.,Tan, K.L., Electrochim. Acta, 101 (1999), 800 .

15. Silva, J.E.P., Dissertação de Mestrado: "Caracterização Espectroscópica da Polianilina Dopada Primariamente e Secundariamente”. Instituto de QuímicaUniversidade de São Paulo, Brasil, (1999).

16. Mei, L., Sutharaman, S., He, K., Sensor Actuat B-chem, 67 (2000), 149.

17. Torresi, R.M., Torresi, S.I.C. de, Gabrielli, C., Keddan,M., Takenouti, H., Synth. Met., 61 (1993), 291.

18. Mello, R.M.Q., Torresi,R.M., Torresi, S.I. Cordoba de, E.A. Ticianelli, Langmuir, 16 (2000), 7835. 
19. Varella, H., Torresi, R.M., Buttry, D.A., J. Braz. Chem. Soc., 11 (2000), 32.

20. Zinger, B., Miller, L.L., J. Am. Chem. Soc., 106 (1984), 6861.

21. Lau, A.N.K., Miller, L.L., J. Am. Chem. Soc., 105 (1983), 527.

22. Massoumi, B., Entezami, A., Eur. Polym. J., 37 (2001), 1015.

23. Konturri, K., Pentti, P., Sundholm, G., J. Eletroanal. Chem., 453 (1998), 231.

24. Pernaut, J.M., Reynolds, J.R., J. Phys. Chem. B, 104 (2000), 4080

25. Huang, H., Liu, C., Liu, B., G. Cheng, S. Dong, Electrochim. Acta, 43 (1998), 999.

26. Pio, M., Reynolds, J.R., Synth. Met., 71 (1995), 2233.

27. Pio, M., Maeder, G., Kennedy, R.T., Reynold, J.R., J. Eletroanal. Chem., 368 (1994), 329.

28. Hepel, M., Mahdavi, F., Microchem. J., 56 (1997), 54.

29. Miller,L.L. Zhou, Q.X., Macromolecules, 20 (1987), 1594.

30. Xu, H., Wang, C., Zoval, J., Madou, M., Biosens. Bioeletron., 21 (2006), 2094.

31. Smela, E., Gadegaard, N., J. Phys. Chem. B, 105 (2001), 9395.

32. Sansiñena, J.M., Olazábal, V., Otero, T.F., Polo da Fonseca, C.N., De Paoli, MA., Chem. Commun., 22 (1997), 2217.

33. Otero, T.F., Sansiñena, J.M., Bioelectron. Bioenerget., 42 (1997), 117.

34. Gandhi, M.R., Murray, P., Spinks, G.M., Wallace, G.G., Synth. Met., 73 (1995), 247.

35. Choi, B.Y., Chung, I.J., Chun, J.H., Ko, J.M., Synth. Metals, 99 (1999), 253.

36. Kasemo B., Lausmaa, J., Crit. Ver. Biocompat., 2 (1986), 335.

37. Hoffmam, A.S., Biomaterials: Interfacial Phenomena and Applications, ACS Press (1982), 3.

38. Vrman, L., Blood, Natural History Press, (1967), 13.

39. Courtney, J. M., Lamba, N.M.K., Biomaterials, 15 (1994), 737.

40. Chen, Y., Kang, E.T., Neoh, K.G., Synth. Met., 110 (2000), 47.

41. Lim, V.W.L., Kang, E.T., Neoh, K.G., Synth. Met., 119 (2001), 261

42. Wang, C.H., Dong, Y.Q., Sengothi, K., Synth. Met., 102 (1999), 1313.

43. Kang, E.T., Neoh, K.G., Tan, K.L., Prog. Polym. Sci., 23 (1998), 277.

44. Bruguerolle, B., Clin. Pharmacokinet., 35 (1998), 83.

45. Wichterle, O., Lim, D., Nature, 185 (1960), 117.

46. Hoffmam, A. S., Adv. Drug Deliv. Rev., 54 (2002), 3. 
47. Peppas, N.A., Bures, P., Leobandung, W., Ichikawa, H., Eur. J. Pharm. Biopharm., 50 (2000), 27.

48. Dagani, R., Chem. Eng. News, 75 (1997), 34.

49. Murdan, S., J. Control. Release, 92 (2003), 1.

50. Gehrke, S.H., Drug and Pharmaceutical Sciences, V. 102: Transport Process in Pharmaceutical Systems, Marcel Dekker, (2000), 473.

51. Klech, C.M., Encyclopedia of Pharmaceutical Technology, V. 6, Marcel Dekker, (2000), 415 .

52. Gehrke, S.H., Lee, P.I., Specialized Drug Delivery Systems, Marcel Dekker, (1990), 333.

53. Gupta, P., Vermani, K., Garg, S., Drug Discov. Today, 7 (2002), 569.

54. Korsmeyer, R.W., Peppas, N. A., Controlled Release Delivery Systems, Marcel Dekker, (1983), 77.

55. Stoy, V. A., Encyclopedia of Pharmaceutical Technology, V.6, Marcel Dekker, (1999), 91.

56. Kost, J., Encyclopedia of Controlled Drug Delivery, V. 1, John Wiley and Sons, (1999), 445.

57. D'Emanuele, A., Staniforth, J.N., I. Pharm. Res., 8 (1991), 913.

58. Brown L., Edelman, E.R., Langer, R., J. Pharm. Sci., 85 (1996) 1271.

59. Heller, J., Baker, R.W., Gale R.M., Rodin J.O., J. Appl. Polym. Sci. 22 (1978), 1991.

60. Wuthrich, P., NG S.Y., Fritzinger B.K., Roskos K.V., Heller J., J. Control. Release, 21 (1992), 191.

61. Pitt, C.G., Gu, Z-W., Hendren, R.W., Thompson, J. ,Wani, M.C., J. Control. Release, 2 (1985), 363.

62. Ferreira, L., Vidal M.M., Gil M.H,. Int. J. Pharm., 203 (2000), 149.

63. Gutowska, A., Bae Y.H., Feijen, J., Kim, S.W., J. Control. Release, 22 (1992), 95.

64. Kim, B.C., Wallace, G.G., Polymer, 41 (2000), 1783.

65. Rubinstein, I., Anal. Chem, 56 (1984), 1135.

66. Yue, J., Epstein, A.J., MacDiarmid, A., Mol. Cryst. Liq. Cryst., 189 (1990), 255.

67. Wei, X., Epstein, A.J, Synth. Met., 74 (1995), 123.

68. Torresi, R.M., Maranhão, S.L.A., J. Electrochem. Soc., 146 (1999), 4179.

69. Yang, H., Bard, A. J., J. Electroanal. Chem., 339 (1992), 423. 
70. Vidotti, M., Dall Antonia, L.H., Cintra, E.P., Torresi, S.I.C. de, Electrochim. Acta, 49 (2004), 3665.

71. Small, C.J., Too, C.O., Wallace, G.G., Polymer Gels and Networks, 5 (1997), 251.

72. Costa A.M.A., Amado A.M., Polymer, 41 (2000), 5361.

73. Costa A.M.A., Amado A.M., Sol. State Ionics, 145 (2001), 79.

74. Boyer, M.I., Quillard, S., Cochet, M., Louarn,G., Lefrant, S., Electrochim. Acta, 44 (1999), 1981.

75. Hames, B.D., Rickwood, D., Gel Electrophoresis of Proteins - a pratical approuch, 2nd ed., IRL Press, (1990), 5.

76. Peppas, N. A., Barr-Howell, B.D., Hydrogels in Medicine and Pharmacy, Vol. I, cap. 2, CRC Press, (1998), 27.

77. Righetti, P.G., J. Chromatogr. A, 698 (1995), 3.

78. Cheng, K.L.U., Imamura, T., CRC Handbook of Analytical Reagents, Vol 4, (1982), 35.

79. Righetti, P.G., Brost, B.C.W., Snyder, R.S., J. Biochem. Bioph. Meth., 4 (1981), 347.

80. Lira L.M., Torresi, S.I.C. de, Electrochem. Commun., 7 (2005), 717.

81. Schlesinger, M., Interface, 12 (2003), 19. 